University of San Diego

Digital USD

1987

\title{
A College Athletic Department - An Example of a High Performance System Existing in an Organized Anarchy Known as a University-Higher Education Organization
}

June Townsend Scopinich EdD

University of San Diego

Follow this and additional works at: https://digital.sandiego.edu/dissertations

Part of the Leadership Studies Commons

\section{Digital USD Citation}

Townsend Scopinich, June EdD, "A College Athletic Department - An Example of a High Performance System Existing in an Organized Anarchy Known as a University-Higher Education Organization" (1987). Dissertations. 507.

https://digital.sandiego.edu/dissertations/507

This Dissertation: Open Access is brought to you for free and open access by the Theses and Dissertations at Digital USD. It has been accepted for inclusion in Dissertations by an authorized administrator of Digital USD. For more information, please contact digital@sandiego.edu. 


\section{A COLLEGE ATHLETIC DEPARTMENT - AN EXAMPLE OF $A$ HIGH PEREORMANCE SYSTEM EXISTING IN AN ORGANIZED ANARCHY KNOWN AS A UNIVERSITY-HIGHER EDUCATION ORGANIZATION}

by

June Townsend Scopinich

A dlssertation submitted in partlal fulfillment of the requirements for the degree of

Doctor of Education

1987

Dissertation Committee

Wlllam P. Foster, Ed.D., Director Patricia Lowry, Ph.D.

Wall ace F, Cohen, Ed.D. 


\section{Copyrighted by}

\section{June Townsend Scopinich}

May 1987 


\section{ABSTRACT}

A COLLEGE ATHLETIC DEPARTMENT - AN EXAMPLE OF A HIGH PERFORMANCE SYSTEM EXISTING IN AN ORGANIZED ANARCHY KNOWN AS A UNIVERSITY-HIGHER EDUCATION ORGANIZATION

The researcher in this study sought an empiricia example of a Vaill's high performance system withlis the university-higher equation organization. This investigation wili assist leaders within colleges and unlversities in having a greater understanding of ine organizational structure of their own institutions by offering a new theoretical perception. The resulis will be analyzed with the prospects of utilizing this information to address such theoretical questions as: how did the athletic department achleve this high level of performance and how was the athletic department able to exist as a $h: g h$ performance system witnin the unlversity organizaston that is often characterlzed as an organized anacchy ans a loosely couplea system.

Th:s study, which extended from January. 1985 to May. 1986, was conducted using the athletlc department of the University of California, San Diego. The sample consisted of forty-one subjects: the Athletic Director, ten coaches. and thicty athletes.

The research design was a case study that used the focused interview technigue. An interview guide, that was designed by the researcher, was used during the interview 
portion of this research. It consisted of 34 questions. Each of these questions were designed to reflect a specific criterion and or araracer st d of a high performance system as defined by $V_{21} 11$. These questions were used to see if in fact the University of Californla. San Dlego"s athletic department could be defined as a high performance system.

Each of the questions were anzlyzed to see whether or not the response was in agreement with the response given by the Athletic Director. A 70 percent level of agreement was established. Each question had to achieve this 70 percent agreement between the Athlet: 0 Director's response and the responses off the forty coaches and athletes in order for a question to be used in the analysis of data.

The researcher concluded that the athletic department could be identified as a high performance system. In addressing the question. of how the athlet lo department achieved this ievel of excel:ence the findings suggest that the envifonment outslde ine in lversıty played a signıflcant role in influencing the successful development of the department. The findings also suggest that the athletic department was able to exist as a high performance system within the university organization because of the ability of an organized anarchy and a loosely coupled system to tolerate novel solutions, local accommodations, and a great deal of ambiguity while still maintaining its own unique identity. 


\section{DEDICATION}

To

My famliy

They have enrlched my l Ife

with their love and support.

11 


\section{ACKNOWLEDGEMENTS}

The completion of this dissertation was not wlthout credit to the many people who were such a valuable resource.

I an grateful to Dr. Wllliam Foster for his direction and support of my research. In addition, I am grateful to Dr. Patricia Lowry for her Input and sensitivity. Finally, I thank you, Dr. Wall ace Cohen, for your pragmatic evaluation of this research.

A special thanks to JoAnn Forbes, who is the coordinator of the mlcrocomputer $1 \mathrm{ab}$ at Southwestern College, for assisting in the editing and in printing the final copy of this dissertation. To Dr.Barbara Blourock, thank you for all the effort you gave in revlewing and verifying my tape recordings.

I wish to thank Judy Sweet, the Athletic Director at the University of California, San Diego, for her support and effort regarding this research. I am also grateful to the coaches and athletes of UCSD who gave of their time during the interview portion of this study.

I especially wish to thank Nan Haugen for her personal and professional support. To the support group, Barbara, Jean, Marilyn, and Sue, a speclal thanks. Lastly, I wish to thank my parents and slsters who have remained loving and supporting throughout my entire personal and professional career. 
DEDICATION

LIST OF GRAPHS

LIST OF APPENDICES

CHAPTER

I. INTRODUCTION 1

Statement of the Problem 6

Research Questions 7

Impllation for Educational Leadership 8

Definition of Terms 9

II. REVIEW OF LITERATURE 14

Introduction $\quad 14$

The University: Traditional Views 17

The University: Contemporary Theory 28

Organized Anarchy 28

Loose Coupling 39

The University as an Organization 45

The Educational Organization and the 49 Environment

Athletics in the University 55

Athletics in America 67

Excellence and High Performance 82

The Athletic Dilemma: High Performing 88 System or Anarchy 
I I . METHODOLOGY 92

The Case Study 92

Limitations of the Case Study Method 94

Limitations of the Study 96

The Sample 96

Development of the Instrument 98

Interviews 98

Data Gathering $\quad 100$

Data Analysis $\quad 100$

IV. ANALYSIS OF DATA 104

Research Questions 1 and $2 \quad 106$

Interview Question $1 \quad 106$

Interview Question 3A \& B 108

Interview Question 4

Interview Question 5A \& B, 7 114

Interview Question 10C 119

Interview Question $11 \mathrm{~A} \quad 122$

Interview Question 6A \& B 125

Interview Question 12A \& B 125

Interview Question 12C 126

Interview Question 14A 136

Interview Question 14B \& C 137

Interview Question 15A 145

$\begin{array}{ll}\text { Summary } & 147\end{array}$

v. SUMMARY, CONCLUSIONS, AND RECOMMENDATIONS 152

Sumnary of the Purposes of the Case Study 152

$$
\mathbf{v}
$$


Conclusions: Research Questlons 1 and 2

Conclusions: Research Question 3

Conclusions: Research Question 4

Implications of the Findings on Present 168 Theory

Recommendations for Future Research 171

Summary of Research 172

$\begin{array}{ll}\text { REFERENCES } & 173\end{array}$

$\begin{array}{ll}\text { APPENDICES } & 190\end{array}$

VI 
1 Interview Question \#1: How would you compare the performance of your athletic department (or team) with other Division III departments( or teams)?

2 Interview Questions \#3A \& B: How would you compare the athletic department (or your team) now to where it was when you first arrived at UCSD? Do you feel there has been a leveling off, or a decrease in development?

3 Interview Question \#4: Has the athletic department (or your team) ever been iudaed by others to be better than other DIvision III departments (or teams)? the athletic department (or your team)? Based on your knowledge do you feel that it's above average, average, or below average in relationship to other Division II athletle departments (or teams)?

5 Interview Question \#7: How would you compare the athletic faclilties at UCSD with other Division III institutions: above average, average, or below average?

6 Interview Question \#10C: Would you say the athletic department better reflects its own culture rather than the unlversity as a whale?

7 Interview Question \#11A: What would you say are the broad purposes of the athletic department of UCSD?

8 Interview Question \#6A: As a department is there (or As a coach is there or Does your coach make) a concentrated effort to recruit talented athletes?

9 Interview Question \#6B: Based on your knowledge 134 do you feel that the talent represented by the student/athletes in the athletic department (or on your team) is above average, average, or below average in relationship to other Division I I departments (or tzams)?

$$
\text { vil }
$$


LIST OF GRAPHS (Cont'd)

Graph

Page

10 Interview Question \#12A: Do you feel that the

UCSD atblet le team coaches (or you as a coach

or your coach) give extra effort beyond what is expected of them ( or you or him/her)?

11 Interview Question \#12B: How committed do you feel the coaches are (or you are or your coach is) to your previously stated broad purposes and objectives of the athletic depar tment?

12 Interview Question \#12C: How would you describe 140 the motivation of the coaches? (coaches only How motivated are you?)

13 Interview Question \#14A: How often do you meet 144 your direct supervisor (or the individual whose responsibilities include the athletic department)? (Omit this question for the team members.)

14 Interview Question \#14B: How much autonomy do 146 you have in your posltion? Are you often revilewed?

15 Interview Question \#14C: As a department (or coach), do you have any interactlons with other departments within the universityeither formal or informal contacts?

16 Interview Question \# 15A: How would you describe how the rest of the university percelves the athletic department? 


\section{LIST OF APPENDICES}

Appendix
A Copy of the questions in the interview gulde
B Copy of the data sheet
C Copy of the reglonal and national championships UCSD's athletic teams participated in or won from 1981 through 1985
D Copy of the regional and national champlonships UCSD's athletic teams participated in or won during the $1985-86$ school year
$\mathbf{E}$
Copy of a signiflcant article from the UCSD's school newspaper
$\mathbf{F}$
Copies of the Response Analysis Forms used in the data analysis
$\mathbf{G}$
List of questions not used in the analysis of and the percent of agreement achieved
H Letter from Dr. Barbara Blourock varifying the accuracy of the transcription of the tapes of the interviews 


\section{CHAPTER I}

\section{INTRODUCTION}

Most colleges and universitles glve the appearance as being ratlonally organlzed instltutions that are gulded by well educated men and women in leadershlp positions. These institutions can be characterized by their clearly stated goals and purposes that are contalned in most of their catalogues. The presidents of these organlzations suggest to all that they are both knowledgeable and capable of running these rationally orlented institutions. Combined into the administrat Ive structure of most university-higher education systems are such organizational roles as vice-presidents, deans, asslstant deans and department chalrs. These roles are delegated to individual members that help the President run the instltutlon and implement the pollcies. At the bottom of this traditional hierarchy are the many faculty members organized into different departments by varlous academic disclplines. All seem, to the uninitlated, to be united in their prescribed tasks toward achleving the Institution's goals and purposes. Many organizatlonal theorists, however, vlew these educational organizations as being nonrational in nature. Many of them think of university-higher education 
Inst I tutions as belng organlzed anarchles (March \& Olsen, 1979) that exhlbit loosely coupled characterigtics (Welck, 1982) and reflect fundamental amblgulties. Vlewing these organizations as organized anarchles and loosely coupled assemblages implies that the components or unlts within the organlzation are weaker and have fewer common elements than previously thought (Welck, 1978, p.57).

Although these theorlsts describe the university organlzation in compatible, non-rational terms, the ambigulty that is central to both theorles is also central to thelr results. They do not tell us why or how the exhiblted organlzed anarchy or loosely coupled characteristics occur. Thus, they seem to eliminate much of the practical application of their theories. Torbert seems to agree with this thought when he states that Cohen and March's

findings...(describes) what education currently does net do... the findings hold no logical

Implications or emplrical clues about: (1) what education eught to do, (2) how education might do what it ought to do, or ( 3 ) which of their alms, strateqles or behaviors educational practitloners would need to reform in order to educate more successfully (1981. p.143).

The Inablilty of these theorlsts to explain educational Institutions in more clearly definable terms is an issue invalved in thls research. 
There are varlous concepts about organizatlons and education that are also central to this research. Contemporary organlzation theory is abandoning a ratlonal-model approach to organlzatlons and beginning to adopt social, polltical and cultural perspectives (Serglovannl, 1984). The major propositions of contemporary theory are:

1. That the loose coupling and organized anarchy theorles should not be viewed as competing but rather as overlappling and compatible theorles.

2. That educational leaders are hampered by the Inadequacy of present organizational theory.

3. That our lack of understandling of organlzations is perpetuated by the simplicity of the myth of organlzation as a monolith (Bennis, 1985, p.49).

4. That part of this problem is the lack of understanding of the various "organizational selves" or substructures that exist in all organizations (Benn1s, 1985, p. 48,50 )

5. That organlzational analysis of unlversities should be vlewed from a cultural perspect ive that acknowledges that within the unlversity there exists various subcultures, each seeking to promote and maintain Its own values (Serglovanni, 1984, p.1,8).

6. That schools do not exist in a statlc world but that because their environment is in a constant state of flux the 
relationship between the school and 1 ts environment must be continuously refined (Abbott, 1975, p.176).

7. That education is one of the major Institutions in America today. As such, education is flrmly established within the basic fiber of our society and culture. Therefore, education can be consldered an Instrument of cultural needs allowing soclety to get the type of education It wants (Goodman, 1962, p.26; Ross, 1958, p.9).

8. That, although the standard portrait of schools many times deplcts weak Ineffective organizations, educational Institutions, unlike other types of organizations, fall infrequently. Perhaps, as some authors suggest, the faulty analysis is due, in part, to the researchers having the wrong model in mind (Meyer, Scott \& Deal, 1983, p.49; Welck, $1982 \mathrm{a}, \mathrm{p.6732}$.

9. That, "In most large organizations different subunlts face different environments... The more diverse the environments that diffecent units face, the more differentiation in structure is needed" (Bolman \& Deal, 1984, p.47).

10. That external environment is a powerful determinant on designing internal structure and process (Jackson \& Morgan, $1982, p .260$ ).

11. That loose coupling of structural elements may cause departmental unlts to vary independently and "provide a more sensitive mechanism to detect environmental varlatlon" (Welck, 1982, p.387). 
12. That as organizational environments become more diverse, the need for horlzontal communication increases (Bolman \& Deal, 1984, p.42).

13. That communlcation is significant to the success and fallure of human systems (Capalle, 1979, p.8).

14. That in loosely coupled systems flawed feedback, or the Inability of the various units to communicate, is often the major source of looseness (Welck, 1982, p.402).

15. That ambloulty can occur because information is Incomplete or ambiguous or is interpreted in different ways by different people (Bolman \& Deal, 1984, p.12).

In the past, many of these perspectives have been absent from the research of university-higher education organizations. These propositions, however, guided this research toward taking a more multl-faceted approach in the study of colleglate Institutions as organizations. Although such theorlsts as Cohen, March, and Welck describe organizations as amblguous, loosely coupled entities, the multi-faceticity of these organizatlons seems to need additional explanation in order to provide the practical guldelines that so many educational leaders seek.

One theorist who has proposed a relatively new concept that could help explain the colleglate organization in clearer terms is Valll (1982). Valll sees organizatlons as high performance systems. Although this model seems in direct opposition to the theorles of Cohen, March, and Weick the question posed by this research is are these models of organlzations really Incompatible? Or, can high performance 
systems exist within an ambiguous, loosely coupled system? The research wlll demonstrate that the latter option is true by showing how a hlgh performance system- an athletic department- exlsts within a loosely coupled environment. Further, thls research shows what ingredients contribute to the development of this high performance system by dolng an analysis of interviews with members of the subsystem within a hlgher education organization.

\section{STATEMENT OF THE PROBLEM}

Two theorles about university-higher education organlzations have been developed-- organized anarchy and loose coupling. These two theorles are not incompatible but rather are intertwined in their descriptive analysis of the nonrational nature of educational organizations. One purpose of this study is to look beyond these descriptive terms and find a possible explanation of how excellent performance can occur in an organization described as anarchic and loosely coupled. The case: an athletlc department whlch year after year produces excellence despite the so-called anarchic quality of hlgher education organizations. This also might be true of other university departments, but the focus of this research wlll be on an athletlc department.

Another purpose of this study is to demonstrate emplrically that an example of Valll's high performance system exists within the unlversity-higher education organization. Although this model is not now used to 
describe the university and therefore can be consldered a competing way of looking at the organization and how it performs, it is hoped that by finding an empirical example of this model within the university its organizational structure will be given greater clarity of understanding. Perhaps the ambigulty shown by educational institutions could then be explained by the existence of different types of organizatlonal systems making up the different parts of university; 1 .e., an athletlc department defined as a hlgh performance system. The exhiblted ambigulty may be caused by the differences between the goals and purposes of each of the Individual parts and the stated goals and purposes of the university as a whole. Perhaps, then, this would offer one explanation as to why the university, as an organization, shows such ambigulty and complexity and is so difflcult to define.

\section{RESEARCH QUESTIONS}

1. Can an athletic department be found, within the university-hlgher education organization, that can be characterlzed as a hlgh performance system?

2. If so, what makes it a hlgh performance system?

3. If an athletic department is found to have characterlstics of high performance systems, how did it achieve this ievel of excellence?

4. How can a high performance system exist in an organization described as an organized anarchy and or a loosely coupled system? 


\section{IMPLICATION FOR EDUCATIONAL LEADERSHIP}

Leadership is a process whereby the leader with certain motives and purposes moblilze resources so as to arouse, engage, and satisfy the motives of the followers in order to realize mutually held goals (Burns, 1978, p.18). This process is exercised in a condltion of competition and conflict in whlch the leader's appeal to the motlve bases of potential followers. Leaders, then, Induce the followers to act for certain goals that cepresent the values and motivation of both the leader and the followers (Burns, 1978, pp.18-19).

It is within this reciprocal process, inherent in leadership, that the importance of this research becomes apparent. Baslc to this concept is that the leader elther satisfles mutually held goals or induces the followers to act for certain goals. If, then, an empirical example of a high performance system can be found within the university-higher education organization, it would have to be acknowledged that there were at least two organizations with different goals functioning within the same institution. The organized anarchy with its vague inconsistent goals is quite different from a high-performance system that 19 characterized by clear purposes and objectives. Leadership, because of its reclprocal process, would be directly effected by this possibllity of different parts of the educational organization having differing gaals because in order to lead 
and change goals for the benefit of the whole ingtitution the leader must approach the various parts of the university organlzation. One part might be in complete accord with his/her stated goals whlle another part might be in complete opposition.

In the university-higher education organization, it is usually the President who must be concerned with the institution as a whole. Because of this possibility of two organizations percelved as one, it is the President who must deal with two units exhibiting different goals and purposes. But, Instead of thls amblgulty being masked by the label of organized anarchy, thls research could help the Presldent to better understand the unlversity-hlgher education organization. Also, as the leader, it would aid him/her in understanding just what hls/her followers' goals and objectives really are. Only then will the President be able to lead his/her unlversity and transform the followers by comprehending their differing goals.

\section{DEFINITION OF TERMS}

Ambloulty signifies that there are four major kinds of opaqueness in organlzations: Intention, understandlng, history, and organization (March \& 0lsen, 1979).

Culture is a pattern of basic assumptions- invented, discovered, or developed by a given group as it learns to cope with its problems of external adaptation and internal integration- that has worked well enough to be considered 
valid and, therefore, to be taught to new members as the correct way to percelve, think, and feel in relation to those problems (Schein, 1985).

Discrediting means that all past experience has lots of surplus meaning and there is no reason to think that we have exhausted the meanings of that experlence by how we currently process it (Welck, 1977a).

Dlvislon. I refers to a specific classification of four-year intercolleglate programs by the N.C.A.A. In order to be classifled Division I an Institution must meet the following criterla:

1. Must sponsor a minimum of six varsity Intercolleglate sports involving all-male teams or mixed teams of males and females in Dlvision I.

2. Must sponsor six varsity intercolleglate sports involving all-female teams in Division I.

3. May award flnanclal aid based on athletic $a b 111 t y$.

4. Must place an annual $11 \mathrm{mlt}$ of athletlc based awards on the following sports: 15 awards for men's basketbal 1, 15 awards for women's basketbal 1, 10 awards for women's gymnastics, 8 awards for women's tennis, and 12 awards for women's volleyball.

5. May administer 137 awards to all other men's sports and 92 awards to all other women's sports based on athletic abllity. 
6. All awards based on athletic abllity must not exceed the value of commonly accepted educational expenses at that institution (National Collegiate Athletic Association, 1985).

Division II refers to a speciflc classiflcation of four-year intercolleglate programs by the N.C.A.A. In order to be classifled Division II as institution must meet the following criteria:

1. Must sponsor a minimum of four varsity intercol legiate sports involving all-male teams or mixed teams of males and females in Division II.

2. Must sponsor four varsity intercolleglate sports involving all-female teams in Division II.

3. May award financlal ald based on athletic $a b j l i t y$.

4. Must place an annual limit of athletic based awards on the following teams: 45 awards for men's football and 12 awards for men's basketball.

5. May adminlster 57 awards to all other men's sports and 110 awards to all other women's sports based on athletlc abllity.

6. All awards based on athletic abllity must mot exceed the value of commonly accepted educational expenses at that institution (National Colleglate Athletic Association, 1985).

Division. II refers to a specific classification of four-year intercolleglate programs by the N.C.A.A. In order 
to be classified Division III an institution must meet the following criteria:

1. An institution shall not award financlal ald to any student/athlete except to those showing a financlal need.

2. All forms of $f$ nancial assiatance to student/athletes shall be handled through the regular college agency or comittee that administers ald for all students.

3. Shall not utllize any form of a letter of intent or similar form of commitment when recruiting a student/athlete CNational Collegiate Athletic Assoclation, 1985).

High-performance systems refers to human systems that perform at levels of excellence far beyond those of comparable systems (Vaill, $1982 \& 1984)$.

Jelnt optimization is a stream of processes in a work system in whlch the various elements are behaving according to, but not beyond, the 1 lmits set by the laws that govern their behavior, and in whlch the behavior of any particular element is not preventing some other element from behaving in accordance with the laws that govern it (Vaill, 1978).

Leoge coupling conveys the ldea that even though coupled events are responsive they preserve their own ldentity and offer evidence for their own physlcal or logical separateness (Welck, 1976). 
N.C.A.A, refers to the National Colleglate Athletic Assoclation (Natlonal Colleglate Athletic Association, 1985).

Qraanlzational coles are names given clusters of component tasks which the agency has decided to designate to Individuals (Argyrus, 1978).

Organlzed anarchy refers to organizations that can be characterized as having vague and inconsistent goals, unclear technology, and fluid partlcipation (Weiner, 1979 ).

Puroosing refers to that continuous stream of actions by an organization's formal leadershlp whlch have the effect of inducing clarity, consensus, and commitment regarding the organlzation's baslc purposes (Valll, 1982).

Subculture is the set of cultural patterns that sets a group apart from larger soclety or a larger organization (Phlllips \& Schaefer, 1976). 


\section{CHAPTER II}

REVIEW OF LITERATURE

\section{INTRODUCTION}

Educational organizations are created to produce schooling for corporate society... As their purposes and structures are deflned and institutionalized in the rules, norms, and ideologies of the wider soclety, the legltimacy of schools and their ability to moblilze resources depend on maintaining congruence between thelr structure and these socially shared categorlcal understandings of education (Meyer \& Rowan, 1978 , p.94-95).

Thus, the very character of the organizational structure of universities and colleges are linked to the meaning society gives these institutions (Kamens, 1977, p.217). Although influenced and formed by Amerlcan culture, the structure of educational organizations resist classiflcation in terms of any model cGross \& Brambsch, 1974, p.5). Traditional models portray the American unlversity as being pluralistic in nature, as being a multiversity, and as beling characterlzed by intense discipl Inary 
speclalizations. However, contemporary organizational theory uses the organlzed anarchy theory and the loosely coupled systems model to describe the amblguity and looseness exhlbited by universities and colleges as they exist in thelr modern complex world.

These varlous concepts and important aspects involving the higher educational organization are central to the lssue being researched in this dissertation. Both traditional and contemporary organizational theory describe certain processes inherent in higher education organlzations but not others. The question is why? Why is the complexity that is exhibited by these organizations so difficult to define? To explore these questlons and the ldeas used to describe the processes and their effect on the hlgher education organizations, both traditional and contemporary theories will be discussed. These theories will be dlscussed first because they are central to present-day conceptualization of hlgher education organlzations.

Literature concerning the university as an organlzation will also be reviewed in order to provide a theoretical basis for the research involved in this dissertation. Particular attention wlll be given to the organizational qualities of the university, the environment surrounding educational institutions, and the effect of the environment on the very structure of the higher education organization. However, as prevlously stated these theorles and analyses do not explain higher education organizations clearly enough to remove contradictions and confusion. 
Whether the authors discuss higher education organizations using traditional or contemporary theory they all seem to acknowledge the complexity and amblgulty surrounding these organizations. Perhaps, by studying the patterning of the processes that effect the structure of academic institutions these organizations could be better explained. Welck (March, 1976) seems to agree with this when he stated that it is not the existence or nonexistence of loose coupling that is cruclal to determining the functioning of organizations but, rather the patterning of the couplings (p.363).

Because the central focus of this research is to provide a better understanding of the university as an organization, one particular disciplinary area will be studied to possibly help provlde a greater understanding of Its organizational patterning. Athletics, which is so deeply rooted in the university structure and such a perslstent part of every institution of higher learning, will be used as an example of a disciplinary specialization. A revlew of literature will be conducted involving athletics In the university.

Scott (1983) states that organizatlons are imprinted by the forces that surround them at the time of their creation. Therefore, organizations formed during one time perlod tend to assume a specific character that is carried forward during their entire organizational 1 ife (p.169). Assuming this is true, the effect of Amerlcan culture on the athletics in higher education wlll be revlewed in order to 
have a greater understanding of athletlcs and how it came to have the speclfic organlzational characteristlcs it seems to display at the university level.

Finally, athletles will be studied as an organization that stresses and demands a high level of success from the people Involved in its activities. Probably there is no other area in the university that demands such a high performance level from both the faculty member and the student. The coach must win in order to get and keep hls/her job. The student/athlete must have displayed above average abllity and performance levels in order to be a member of most university teams. Can these performance expectations label the athletic department as a high performance system? A review of 1 iterature will be conducted to explore what is meant by a high performance system.

II. THE UNIVERSITY: TRADITIONAL VIEWS

One of the most important organizational features that influence the diversity found in American universitles is the environment in which the Institution exists. The environment includes such things as the relations with other social Institutions, context of financial support, and formal control. Because of this encompassing nature, the environment is very important in determining the inst Itution's decision making process (Baldridge et al, 1977b, p.53). Meyer and Rowan support the view of the environment shaping the structure of the organization. The 
authors state that universities have become very pluralistlc in nature because they have had to adapt to the complexity of their environments (1983, p.89). The Stanford Project on Academlc Governance demonstrated how plural ist lc the Amerlcan university really has become. The study found that unlversities can be placed in different categorles that reflect different organizational features and different patterns of professional autonomy for their faculties (Baldrldge et al., 1977b, p.42). In supporting this pluralistic view. McConnell (1976) states that "many unlversities were essentially collections of relatively autonomous professional schools and speclallzed departments; these loosely connected parts were in the university but not of the university" (p.277). It is because of this extreme pluralism in the environment of the Amerlcan university that causes the organization to be loosely coupled (Meyer et al.. $1983, p .63)$.

In envisloning the Amerlcan university as having an inconsistent, disjointed and plurallstic nature, it is Kerr (1976) that has popularized the term "multiversity" to descrlbe the university's organizational structure. The author used this term in order to call attention to a new view of the unlversity as a multiversity rather than the older vision of the university as a unified community of schol ars and students (p.277).

The multiversity is an inconsistent institution. It is not one community but several- the community of the undergraduate and the community of the graduate; the 
community of the social scientist, and the community of the sclentlst; the community of the professional schools; the community of the professional schools; the communlty of all the nonacademic personnel; the community of the adminlstrators. Its edges are fuzzyit reaches out to alumnl, legislators, farmers, businessmen, who are all related to one or more of these Internal communitles (Baldridge, 1971, p.118; Kerr, 1972, p.18).

The multiversity, then, has many publics that ldentify less with the unlversity as a whole and more with their own subgroups or subcultures. Same examples of subcultures are faculty, colleglate, and athletes (Kerr, 1972, p.41). "It is helpful to thlnk of these various groups as political parties, each with its own speclal orlentations, values and goals" (Baldrldge, 1971, p.122). Internally, then, universities contain interdependent subunits which compete with each other because of their own self-interests (Sergiovanni, 1984, p.6).

The development of these subcultures can be traced to the intense disciplinary specialization that occurs in the American university. As specializations increase, Iines of connection between disciplines become more tenuous. Specialization, then, fractures the university organization (Baldridge, 1971, p.120; Bennis, 1976, p.24). This fracturing also occurs within the organization's communication network. This is very important for the educational institution because it allows it to meet the 
demands placed upon it by its confllcting and inconsistent environment (Meyer, 1983b, p.191). The structure of the organization becomes more complicated as hlgher levels of speclallzation are achleved (Bolman \& Deal, 1984, p.37). Thus, the university seems to experience the same obstacles to common purpose as most modern organizations encounter. This lack of common purpose is due to their complexity and differentiation. Therefore, universities have difflculty establishing common vision of purpose (Harrison, 1984, p.108).

Probably the most important fact concerning the fragmentation and complexity that occurs in the multiversity is the fact of multiple subcultures within the university. These subcultures make the governance of the institution complicated and difflcult (Baldridge, 1971, p.122; Clark, 1965, p.237). Because the governance of the multiversity must take Into account the conflict due to the Interaction of Its varlous parts and subcultures, the power within the organization is greatly fractionallzed (Kerr, 1972, p.140). The net effect is no one is able to consolldate enough power to take positive leadership in developing the university Into an integrated organization (McConnell, 1976, p.277). In fact, Kerr (1972) states that the multiversity is mainly held together by adminlstratlve rules and powered by money (Kerr, 1972, p.140\& \&.20).

This system of subcultures exists within the social structure of the university. The university, though, has other relationships external to its internal social setting 
(Baldridge, 1971, p.123). These external relationshlps between the university's subsystems and the other speclalized subsystems of the larger external system, to which the organization belongs, helps define the character of the organization (Parsons, 1956, p.66). Thus, the education organization can be conceptualized as a subsystem of the broader soclal system to which it belongs. However, conceptually it must be viewed as a dlfferentlated subsystem of the broader social system in which it is embedded. Thls implles that the institution is differentiated from the broader social system because of the particular functions that the organization is expected to perform for the general good of the social system (Abbott, 1975, p.176).

As Meyer and Rowan (1978) state, "modern schools produce education for soclety, not for individuals or families...education becomes the central agency defining personnel...for the modern state and economy" (p.92). The organization, then, is deslgned as a technical implement of society for mobllizing and directing human energles toward set societal aims (Selznick, 1957, p.5). Therefore, the unlversity should be looked upon as an organlzation that is blased in what it emphasizes and what it values colsen, 1979, p.311).

The organizational characterlstics of the American unlversity is thus linked to the meaning that soclety attaches to university attendance (Kamens, 1977, p.217). "...the major function of colleges and universities is symbol lc- to redef Ine graduates as possessing special 
qualities or skills...this is done through legitimizing myths about the quality of education that are validated by the organizational structure of the institution (Bolman \& Deal, 1984, p.170).

Additionally, socletal speciflcations emanating from the environment defines organizational structure in the form of the categorization of puplis, qualifications of teachers, size of classes, and so forth (Meyer, Scott \& Deal, 1983, p.62). Therefore, the organizational characteristics exhibited by the university are causally linked to the meaning that soclety gives to university attendance. In fact, to put it more strongly, changes in the socletal produced concept of the student will produce changes in the organizational structure of the educational institution (Kamens, 1977, p.209). Bennis (1976) agrees with this when he states that another way to change an organlzation is through external events which are the forces of saclety impinging on the organization $(p .90)$.

It seems, then, that many organlzational theorlsts agree that attention must be given to the relationship between the university and soclety. Clark (1965) supports this contention when he states that the education system is probably the most important single lssue In American soclety today. Further, he states that soclal forces in our modern soclety recast education as part of the political and economic institutions of soclety (p.228). Mlllet: (1962) feels a college or unlversity cannot very well ignore these institutlons because $h$ lgher education is influenced by and 
draws financlal support from varlous speciflc areas of soclety. These areas of influence include religion, the economy, phllanthropy, and government $(p .60)$. The financial support provlded by these groups, In many cases, is the difference between whether or not certain areas of the university community recelves favorable support from the central university committee or not. In this way the dominate value of the almighty dollar that pervades American soclety has begun to dominate the values of the university itself (Mooney, 1963, p.45).

Thus, powerful external forces appear to be affecting the very foundation of institutions of hlgher learning in the United States today. Baldridge et al (1977a) concurs with this opinion and feels that because academic institutions are people-processing organlzations these external influences cannot be separated from the unlversity. Cllents with specific needs enter the unlversity helping bring these forces to bear. These clients, in form of interest groups holding conflicting values with the many of the stated values of the unlversity, have made their demands, wishes, and threats known to the faculties and administrators of individual institutions. Thus, they have been able to obtain a signiflcant input into the organizational decision making process $(p .4 \& 6)$.

Paradoxically, then, there is no instltution in America that is more dependent upon, and more vulnerable to, external forces than the university. Universities have become more politlclzed due to their permeabllity to these 
outslde forces. In fact, the author goes on to state, the hlgher education organization is an example of an institution that has diffused the maln purposes for which it was established. This is the result, he feels, of an increased dependence and prol lferation on external patronage organizations (Bennis, 1976, p.8-9\&149).

It is helpful to think in terms of various "publics" that bring pressure to bear on the university, that provide it with services and support, and that indirectly shape its destiny. As the unlversity assumes a critical socletal cole these external influences encroach more and more into academic hall, always pushing and pulling the unlversity toward some partlcular image (Baldridge, 1971, p.123).

These speciallzed groups or publics develop boundary roles in which their principle job is to provide a link between the university and the outside soclety. The link is an important one to the university. The groups reach out to world outside the university and provide a gatekeeper role for the institution. This, however, creates positions of power for the leaders of these groups. Therefore, the leaders become powerful and polltically slgniflcantly within the university because of their role of gatekeepers (Baldrldge, 1971, p. 124). These speclallzed groups include alumnl, board of trustees, researchers involved with governmental agencles, foundations, surrounding industries, and outside athletic interests (Millet, 1962, p.151; Gross \& Grambsch, 1974, p.7; Kerr, 1972, p.122). 
Many critical declsions, then, are belng influenced from outside the educational organizations themselves. These powerful external forces in form of specialized groups are Impingling upon the university on all sldes (Baldridge et al, 1977b, p.54). Millet (1962) feels that power is shared by different constituent groups that come from within and outside the university. Each group possesses substantial power ( $p .62)$. The ever-increasing role of these outside groups in the academic matters of the university is gradually wearing down the internal governance structure of the Institution. As the effective leadership is weakened, the power and initiative which was formerly solely within the university flows even more rapidly to the agencles outside CCarnegie Foundation for the Advancement of Teaching, 1982, p.89).

Educational organizations have been able to achleve success by satisfylng these dlverse external constituents and their respective agencies. Although the actual activity of the organization is not disrupted, the external demands have caused a great deal of adaptation and change (Meyer \& Rowan, 1983, p.92). This change and adaptation, though, need not follow the traditional ldeas of organization theory. Millet (1962) seems to agree with this contention when he states, "I belleve strongly that a college or university has 11 ttle if any resemblance to the generalized conceptlons of organization which may be applicable to certain types of governmental administrative agencies and certaln types of business entities" (p.27). Further, the 
author states that colleges and unlversitles are different from these generalized organizations in institutional setting, in operation, in purpose, and thus in internal organization $(p .31)$.

With academic power and operational responsibility divided and subdivided, again and again, the image of the university as an integral community progressively dlssipates (Mooney, 1963, p.49)

Because of the very nature of the academic profession In higher education, the emphasis placed on academic speciallzation creates within the university a sense of dlsciplinary rather than local or community ldentity (Millet, 1962, p.70). Lutz (1982) suggests that this disciplinary or subsystem identity could possibly been encouraged by the tradition of academic freedom that is a central tenet of the higher education organization. Given academic freedom, the subsystem has complete academic llcense that many times may lead to the unaccountability of the subsystems actions (p.667). There is a tendency of these units in the university organlzation "to exaggerate the importance of their own contribution and to think of the whole organlzation in terms of the goals of the particular unit" (Gross, 1968a, p.8).

Historically, academic freedom was one of the most important goals of the university in America (Gross, 1968b, p.542). But belng the complex organization it is today, the university does not just stress this one goal. The university has one of the most complex goal structures of 
any modern organization. Probably unique to the educational process is the number of output goals each university exhibits (Gross, 1968a, p.16; Gross, 1968b, p.526).

Output goals are those goals of the unlversity which, immediately or in the future, are reflected in some product, service, skill or orientation which will effect (and is intended to affect) society (Gross, 1968a, p.13).

These goals involve output to the surrounding society. They can possibly be best explalned in terms of system linkages. In this sense, because organizations are subsystems of soclety, the output goal of one subsystem becomes the input of a different subsystem. Using this approach necessitates the need to relate organizations to each other and thelr surrounding society. When defining goals, in this way, individuals within the organization have $1 \mathrm{imlted}$ freedom to set the goals of their organization. They wlll be forced to accept what outsiders can be persuaded to accept (Gross, 1968b, p.520).

Gross and Grambsch (1977) have another Interesting theory of unlversity goals and how they could effect the power and leadership structure of the institution. It is their contention that certain goals may attract a particular kind of power holder or make it easier for these people to achleve certain positions within the unlversity. If, in fact, the goal structure helps facilitate the accretion of power to these people, it could be sald that instead of goals beling caused by power holders, goals could cause 
certaln Klnds of power structures to emerge within an Institution (p.27).

I I . THE UNIVERSITY : CONTEMPORARY THEORY

\section{ORGANIZED ANARCHY}

An organized anarchy can be characterlzed by vague and Inconsistent goals or preferences, unclear technology, and fluid particlpation (Cohen, March, and 0lsen, 1972, p.1; Cohen \& March, 1974, P.3; Welner, 1979, p.225; Sproul, Welner, \& Wolf, 1978, p.5; Scott, 1981, p.272). In an organlzed anarchy the organization appears to operate with a number of 111-defined goals that lack a coherent structure and can be better characterized as a loose collection of changing ldeas. These goals are usually discovered through the normal everyday operation of the organization rather than enacted before the actlvities begln (Cohen, March \& 01 sen, 1972, P.1; Cohen \& March, 1974, p.3). An unclear technology is one in which the memisers do not understand the processes inherent in what the organization does. The organization operates on the basis of the resldue of past experience, simple trial-and-error procedures, and practical inventions of necessity <Cohen, March \& 01 sen, 1972, p.1; Cohen \& March, 1974, P.32. Because of this unclear technology, the members of the organlzation have little probabllity of developing or ldentifying courses of action that might have an effect on a speciflc problem (Sproul et al., 1978, p.5). Fluid participation occurs when the particlpants in the organized anarchy vary the amount of 
time and effort they devote to the different domains within the organization. The involvement of each individual varies from one time to another. This varlation in participation is a result of the individual having other demands on their time. As a result, the boundarles of the organlzed anarchy appear to be uncertain and changing (Cohen, March \& 01 sen, 1972, P.1; Cohen \& March, 1974, p.3). Fluld participation, then, recognizes that because of 1 imited resources of $t$ ime and energy Individuals both inside and outside the organization cannot give continuous or stable attention to particular lssues within the organization (Sproul et al., 1978, p.5).

Other authors have also Ident ifled additional characteristlcs of an organized anarchy. Available organizational resources allow individuals within the organization to go in different directions without being controlled or directed by a central authorlty (Baldridge, Curtis, Ecker and Rlley, 1977a, p.8). Therefore, as Cohen and March (1976) state, it is a mistake for any particlpant within the organization to become absolutely committed to any one $p l a n(p .270)$. Also, desplte the organized anarchy's immediate problems of vague and inconsistent goals, unclear technology and fluid particlpation the real subtlety of the organization is its ablitity to continually rearrange and update its structure without ever having a need for a major redeslgn (Welck, 1977a, p.41).

Educational organizations are frequently characterized as organlzed anarchles (Cohen, March \& Olsen, 1972, p.11; 
Padgett, 1980, p.583; Scott, 1981, p.272; Bolman \& Deal, 1984, p.29). "Organized anarchy helps capture the spirit of the confused organizational dynamlcs in academic institutions: unclear goals, unclear technologles, and environmental vulnerabllity" (Baldridge et al., 1977a, p.8). The college or university organization is the prototype of an organlzed anarchy.

It does not know what it is dolng. Its goals are either vague or in dispute. Its technology is familiar but not understood. Its major participants wander in and out of the organization. These factors...make it a problem to describe, understand, and lead (Cohen \& March, 1974, p.3).

Thus, because the university hlgher-education organlzation is described as an organized anarchy, each individual in the university is seen as making independent decisions. Professors decide what is to be learned. Legislators and financial supporters declde what and when to support the institution. Resources are allocated by whatever process emerges and without guldance from organlzational goals. The "decisions" of the institution are a consequence of the system but are controlled by no one (Cohen \& March, 1974 , p.33). The goals of educational inst Itutions, then, are Indeterminate in nature and do not gulde or evaluate indlvidual performance (Welck, 1982a, p.673). As Sproul et al. (1978) state, If goals are measurable in an organized anarchy they are not usually agreed to; if however they are 
acceptable to all members then they are nelther operational nor measurable (p.5).

When an organlzation's goals are vague, inconsistent, or amblguous, the organlzation and its leaders have difficulty completely understanding the nature of the organlzational processes that transform inputs into outputs. It is often difflcult for the leaders to anticipate which cholces in the declsion making process are important and which are unimportant (Weiner, 1979, p.226). Sproul et al. (1978) suggest that the very meaning of the decisions change as different problems enter and leave the decislon process. The way these different problems enter and exit the organlzed anarchy is as much a function of the emotional state of the decision-makers and the uncontrolled external events as it is of rational analysis of gaals. In an organized anarchy, then, the decision-making process aids the Individual and the organization to arrive at socially generated interpretations of what they are doing and helps identify who is important in the organization (p.5). This seems, then, to encourage more ambigulty and difficulties for the institutional decision makers.

There are, in organized anachles, flve propertles of declsion making: low salience, high lnertla, garbage can, overload, weak information base (Cohen \& March, 1974, p.206; Cohen \& March, 1975, p.266-269; Cohen \& March, 1983, pp.343-344; Goodman, 1982, p.33; 0lsen, 1979, p.134; Welner, 1979, p.245). Low sal ience occurs because most people are not as interested in the content of the issue but rather in 
Its symbolic significance for themselves and the group to whlch they belong. The organlzed anarchy organlzation also has the property of high inertia. It is a system that requires a coordinated effort to start or stop and is not likely to be started or stopped. Thus, hlgh Inertia in organized anarchies make the organizational control and power ambiguous. The garbage can property of decision making refers to the fact that any decision can become a garbage can for any problem. The lssues discussed in relationship to the decision making process depends less on the problems or decisions involved and more on the timing of the coming together of these problems and decisions. Because of the importance of timing in matching problems and decisions, the decision making processes of cholces and, thus outcomes, become more separated from the formal process involved with organizatlonal decisions. In other words, "a garbage can is an organization that is a collection of cholces looking for problems, lssues and feelings looking for decision situations in which they might be alred, solutions looking for lssues to which they might be the answer, and decision making looking for work" CCohen, March \& 0lsen, 1972, p.2).

The four:h property of decision making in an organized anarchy is overload. Overload impalrs the processes of cholce. When the system bullds up problems beyond its capabilities for exercising and resolving problems, the organizational decision outcomes tend to become increasingly separated from the formal decision making processes. The 
Ifth property, weak information bases, characterizes an organlzation where past events and decislons are not often retained and information about current activities is almost nonexistent. Decision making in organized anarchles, then, occurs in an organization that can be characterized by these properties and by the extreme ambigulty present in organizational environment (Goodman, 1982, p.33).

Bolman and Deal (1984) also feel that most organlzations are amblguous (p.12). They state that, because of the exhlbited organizational ambiguity, individuals within the organization search for meaning, predictability, and order. The organlzational structure and processes, then, "serve as myths, rituals, and ceremonies that promote cohesion inside organizations and bond organizations to their environment" (1984, p.189). In other words, the structure and processes try to provide a sense of order to the indlviduals that have to exlst in this state of ambigulty. To Weick (1977a), ambivalence in organizations is the most favorable condition for compromise. When something is clear, organlzatlonal actors should doubt those things. When things are unclear, individuals should treat them as if they are clear (p.42).

Organlzational 11 terature suggests that amblgulty can be dependent on and can be a function of varlous aspects of an organization. Some theorists suggest that ambiguity may be a function of the structure of the organization (House \& Rlzzo, 1972, p.473; Schuler, 1977, p.67). Addltionally, Schuler (1977) feels that ambigulty may not be the result of 
the structure but perhaps the result of the lack of appropriateness of the structure with the organization's technology (p.67). Bolman and Deal (1984) suggests that ambigulty is deliberately created in order to avold conflict and conceal problems (p.12).

What exactly, then, is meant by amblguity? The term, as used by March \& Olsen, tends to mean four important kinds of opaqueness in organlzations: intention, understanding, history, and organization. Amblguity of intention can be characterized by inconsistent and 11 l-defined objectives. The amblguity of understanding involves the obscure view of the causal world that many organizations have. Organizational amblguity of history stresses the importance of the past but it is not easily interpreted or flxed. Finally, ambiguity of organization is the pattern of uncertain and changling participation in the organization (1979a, p.12).

Amblgulty is a major quality of most educational organization's decision making processes (Cohen \& March, 1976, p.263; March \& 0lsen, 1979a, p.12; March \& 0lsen, 1979b, p.67). Academlc Instltutlons provide few examples of "real" data. They have nothing closely analogous to production flgures of sales and profit (Cohen, 1979, p.195). Thus, almost any course of action or decision can seem plausible because of inherent amblguity that is basic to the university's technology and objectives (Cohen \& March, 1979, p.182). Additionally, during the decision making process, dependent upon the subject matter being discussed, 
occurring different groups are represented in the process. Groups involved in minor decisions are different from the group involved in major decisions (March \& Olsen, 1979c, p.39).

March and Romelaer (1979) offer the following metaphor in order to lllustrate decision making in a university. Consider a round, sloped, multi-goal soccer fleld on which Individuals play soccer. Many different people (but not everyone) can join the game (or leave it) at different times. Some people can throw balls into the game or remove them. Indlviduals while they are in the game try to kick whatever ball comes near them in the direction of goals they like and away from goals that they wish to avold. The slope of the fleld produces a blas in how the balls $f a l l$ and what goals are reached, but the course of a specific decision and actual outcomes are not easily anticipated (p.276).

The top decision maker in university-higher education systems is the institution's president and it is the presldent that must contend with four fundamental amblguit les:

purpose. In what terms can action be justifled? What are the goals of the organization? power. How powerful is the president? What can he/she accomplish?

experlence. What is learned from events of the presidency? How does the president make inferences about $h / s /$ her experlence? 
success. When is a president successful? How does he assess hls pleasures? CCohen \& March, 1974, p.195; Cohen \& March, 1976, p.262).

Ambigulty of purpose occurs in a university where efforts to specify a set of shared goals, from the actions or activities of the institution, usually show slgns of inconsistency. Ambigulty of power is best illustrated by the presidents of the university and their request to others to understand the unique situation that they are in.

Although they have the prestige of offlce, in actuality the presidents have the countervailing power of other groups to contend with. Ambigulty of experience centers on the world the presicient must live in. Flrst, because the university world is relatively complex, factors that influence presidential actions are not only uncontrolled but are many times unobserved. Second, the academic world is changing so fast that desplte the speed at whlch the president gathers information the situation has the potential for false learning. Finally, an administrator knows that he/she has been successful when promoted to a better job. In the case of the presidency, few individuals are promoted out of the Job. If new offers are presented, the best opportunity a typlcal president can expect is a version of adminlstrative semirotirement CCohen \& March, 1974, pp.195-201; Cohen \& March, 1983, pp.333-340). Although it is the President of the university-hlgher education institutions that must contend with these four fundamental ambigulties, it is the entire institution that is weakened "by the ambiguity of 
goals, by the lack of clarlty in technology, and by the translent character of many particlpants" (Cohen, March, \& 0lsen, 1979, p.25).

University-hlgher education organlzations exist in an environment that is both in a constant state of flux and diverse in nature. The need, therefore, for horizontal communication Increases (Bolman \& Deal, 1984, p.42). Thus, at a time when increased communication is needed, the ambiguity inherent in these organizations seems to cause the communication within the organization to break down because the information provided is either incomplete or ambiguous, or interpreted in different ways by different people (Bolman 8. Deal, 1984, p.12). Thus, educational organizations frequently act on incomplete information without being consclous of all the alternatlves <March \& 01sen, 1979, P.54).

Communication is the central phenomena in organizations. Communication links members of the organization together in a varlety of ways. It serves as the means by which organizations are firmly established in their environments. And, it provides a means of interpreting the inputs and outputs of the organization (Guetzkow, 1965, p.534). As Barnard (1939) states, "In an exhaustive theory of organization, communication would occupy a central place, because the structure. extensiveness, and scope of the organization are almost entirely determined by communlcation techniques" (p.91). 
Communication...can be verbal (oral or written) or nonverbal (the medium is the message). It Involves both content (the overt information transmitted) and process (the ways and means of transmitting the message). Communlcation can oscur along cognitive (thlinklng, conceptual), affective (feeling, emotional) and behavioral (behavlng, doing) channels (Capalle, 1979, (.8).

In an organization, once a pattern of communication has become established it will effect not only the decision making processes but wlll also effect the informal organizational activitles. The communlcation network is both planned and developed in response to social functions and the type of information it is asked to process. Within an organization, it is most difflcult to communicate about nonstandardized objects and intangible objects. Hence, the communication system is most ineffective when it is asked to communicate aspects of unclear tasks and problems not yet well defined (March \& Simon, 1958, pp.164-168). Communication would then seem to be most ineffective or flawed in an organized anarchy with its unclear tasks or technology and vague and inconsistent goals. Welck feels that this flawed feedback or the inabllity of varlous units within an organization to communicate, is often the major source of looseness within the organization (1982b, p.402). 


\section{LOOSE COUPLING}

It is the exhibited looseness or the less tight coupling of organizational parts that Welak (1979) feels is one of the main reasons why the concepts of loose coupling and organized anarchy recelved so much attention so quickly from the varlous academlclans studying organlzational theorles $(p .54)$. The organlzed anarchy assumes a loosely connected organizational world (Cohen \& March, 1974, p.34). Organized anarchy is also the governance system of the loosely coupled organization. Although by definition an anarchy is not a system of government but rather an absence of government, a organized anarchy is a negation, a term Indicating that no one in the organization is accountable (Lutz, 1982, p.656). Lutz (1982) further states that loosely coupled organizatlons and organlzed anarchies are also better able to adapt to their environments because they permit more flexibility in the behavior of their structural subsystems. The basic assumption of loose coupling and organized anarchy, then, is that the other organizational models and theorles fall to account for many of the behaviors observed in organizations (p.653).

Could the causation of ambiguity and loose coupling in organized anarchles, then, suggest that there are different subsystems or substructures all functioning under what had prevlously thought to be one organizational system or structure? Welck (1976) seems to suggest that this could possibly occur in a large system if all of the elements are 
loosely coupled to one another. Being loosely coupled, "the elements can adjust and modify a local unique contingency without affecting the whole system...the identity. uniqueness, and separateness of elements is preserved, the system potentially can retain a greater number of mutations and novel solutlons" (p.360-361).

Welck (1974) is also concerned that organizational theorlsts have not pald enough attention to the possibllity "that organizations have analogous or varlable connections, flexible frameworks, and sliding bonds" (p.380). Loose coupling exists:

... if $A$ affects $B(1)$ suddenly (rather than continuously), (2) occasionally (rather than constantly), (3) negliglbly (rather than significantly), (4) indirectly (rather than directly), and (5) eventually (rather than immediately). Connectlons may appear suddenlyeas in the case of a threshold function; may occur eccaslonallyeas in the case of partial reinforcement; may be negligible,as when there is a damping down of response between $A$ and B due to a constant vaclable: may be indirect, as when a superintendent can affect a teacher only by first affecting a principal; and may occur eventually, as when there is a lag between legislator voting behavior and response by his or her electorate (Welck, 1982b, p.380).

Much of the literature that dlscusses loose coupling suggests that the structural features of organizations can 
vary independently of processes and of outcomes (scott \& Meyer, 1983, p.149) It is this independent or nonrational aspect of loose coupling that indicates why people cannot predlct what happens within their organization (Weick, $1982 b, p .380$ ). Welck (1976) further states that loose coupling can occur elther in one system or two separate gystems. If some parts of one system are weak compared to other parts within the same system or if two systems are jolned by a few common or weak common parts, then it can be said that the systems are loosely coupled. What loose coupling means is that if the parts or variables of a system are disturbed, the disturbance will elther be limited or will take a long perlod of time to effect the other parts of the system or the effects on the system will be weak (p.358). In other words, the system is said to have structural looseness (Welck, 1979, p.185).

It appears, then, that a loosely coupled organization has many characteristlcs:

1. A loosely coupled system is not a defective system. It is a solution to constant environmental change (Welck, 1982b, p.405). Additionally, it is the loose ties in the organization that allows the individuals to successfully cope with serious change in the environment (p.378). In fact, the more open the system is the harder it is to distinguish the system from its environment (scott, 1981 , p.50). Thus, although a loosely coupled system has less necessity for major change, if in fact large scale change becomes a necessity it is more difficult to achleve because 
of the Inherent looseness within the organlzation (Welck, 1982b, p.387). Rubin (1983) supports this when she states that looseness buffers the system from short-term change but hinders the organization from determining and coordinating response to internal and external environmental stresses (p.200).

2. In loose coupling the structural elements seem to be very adaptlve for the organlzatlon. (Scott, 1981, p.50). Loose coupling al lows the system to adapt opportunlstically to small changes in a diverse and segmented environment (Scott, 1981, p.248; Welck, 1979, p.120; Welck, 1982a, p.674; Welck,1982b, p.387). Moreover, the adaptation that occurs is one of localized adaptation. The problems, that develop in one unit and that cause this local adaptation, are sealed off from affecting the other units of the organlzation. Thls allows for the rest of the organization to perform in a stable manner (Weick, 1976, p.360; Welck. 1982a, p.674). While the organization may thus contain new solutions for the problems inherent in the adaption, the very structure of loose coupling stops these mutations from being diffused throughout the entice system (Vaill, 1978, p.361).

3. Loose coupling in systems adds to the stabllity of the entire organization by allowing the system to persist (Glassman, 1973, p.83; Welck, 1979, p.111; Welck, 1983, p.21). Although the system faces variables that normally would disturb the behavior of a system, the weak tles that are inherent in a loosely coupled system promote and 
insulate the system from continual minor changes to events (Welck, 1979, p.112). While loose coupling may promote persistence, it is not selective in what is perpetuated. Thus, "archalc traditlons as well as Improvisations may be perpetuated" (Welck, 1976, p. 360 ).

4. Change in a loosely coupled system is continuous, small scale, improvisational, accommodative, and local. Change diffuses slowly through the loosely coupled system allowing the components of the system to create their own solutions or die (Welck, 1982b, p.390). The current state of the system is the result of continuous change that moves the system away from some original state. The direction of the change need not be toward orderliness (Welck, 1979 , p.120). Therefore, centrallzed change seldom reaches the different parts of the loosely coupled system (Welck, 1982b, p. 398).

5. Differential participation is common in a loosely coupled system (Weìck, 1982b, p.398). As Pfeffer (1978) states, "organlzations are loosely coupled, in part because few particlpants are constantly involved or care about every dimension of the organization's operation" (p.37).

6. Confidence in the structural elements in a loosely coupled system allows an organization to continue its dally routines within a decoupled structure. This confidence is maintalned through three practices: avoldance, discretion, and over looking (Weick, 1982b, p.392).

7. Linkages in an organization can be described as elther tightly or loosely coupled. Coupling defines the 
nature of the connectedness between the unitg of the organization. It also refers to the degree to which events that are occurring in one section of the organization can be felt by other parts of the system (stern, 1979, p.245). Because the type of coupling is loose, there is an absence of tight and rigid connectlons among the varlous parts of the organization. Organizationally, because of the looseness, it can be assumed that parts of the system are capable of autonomous functions (Scott, 1981, p.53).

8. Loosely coupled systems are viewed as "Interlocked behaviors". This allows the individuals within the system to have a great latitude in interpreting and implementing orders (Scott, 1981, p.118). One reason why we call this structure a loosely coupled system is that people in the system are interdependent. But, these tles or interdependencles are different than in other forms of organlzations. They are weaker, more unpredictable, and more intermittent (Welck, 1982a, p.676). Thus, "loose coupling...(Is) anything that may be tied together either weakly of infrequently or slowly or with minimal Interdependence (Welck, March 1976, p.360).

9. Leadership, in a loosely coupled system is diffused rather than concentrated. In order to be effective in such a system, the educational administrator must make use of symbol lc management to tle the system together (Welck, 1982a, p.675).

10. Different people, in a loosely coupled system, have different goals. The goals that exist are developed to 
satisfy local clrcumstances (Weick, 1982a, p.676). Welck (1976) states that loose coupling provides the organization with sensltive sensing mechanlsm to local environments. These independent sensing elements know their environments better because they have fewer externally constrained, Independent parts $(p, 360)$.

11. The relationshlp anong the varlous work groups in an organization is also effected by the looseness of the system (Scott, 1981, p.108). In fact, Ouchi (1978) states that the ldea of loose coupling becomes quite plausible when the organizational hlerarchy is not thought to be based on authority but rather grounded in the ideas of an ordered set of units or work groups resting within larger units within the organization (p.265). Weick (1979) feels that these small units are important to understanding the major worklngs of the organization (p.236). One way a system maintains loose coupling is by having subsystems tightly coupled by the common variables they share (Glassman, 1973, p.84\& \&1).

IV. THE UNIVERSITY AS AN ORGANIZATION

Organizatlonal researchers of hlgher education Institutions have accepted the loose coupling model and the organlzed anarchy theory as accurate descriptions of universitles and colleges in the United States (Bennis, 1976, p.26; Bolman \& Deal, 1984, p.220; Cohen \& March, 1976, P.263; Lutz, December 1982, P.653; Meyer \& Rowan, 1978, p79; Serglovanni, 1984, p.4; Sproul et al., 1978, p.6; Welck, 
1982a, p.673). Two most common coupling mechanisms in organlzations are the technical core of the organization and the authorlty of office. Nelther of these mechanisms are prominent in institutions of higher education found in the Unlted States (Welck, March 1976, p.359). Loose coupling in educational organlzations, then, means that the structure of the organization 13 detached from the technical activity and lts effects. Thus, the loose coupling of the technical or instructional activity within the university permits groups, both inside and outside the institution, to percelve that they have more power in the instructional activities of the organization than in other polley decisions. It also permits education organizations to closely adhere to the ritual categories of education but offer 11 thle control or coordination over instructional activities (Meyer \& Rowan, 1983, pp.71-94; Scott, 1981, p.255; Welck, March 1976, p.354).

Consider, then, the ways that unlversitles and colleges are loosely coupled with their Institutional activities of evaluation, curriculum and technology, and authorlty. The actual work of teaching in the unlversity takes place in the lsolation of the individual classrooms located throughout the institution. Not only are the classrooms effectively removed from organizational controls but the teaching that is occurring is not really subject to inspection or evaluation. Thus, the professor is relatively hidden from administrators and fellow educators and, therefore, free to use broad discretionary powers within the conflines of 
hls/her classroom. Also, missing from the education institution is a guide describing the teaching technology to be followed or a detalled Instructional program. Finally, administrators of these institutlons have little direct authorlty over the instructional work being accomplished (Bidwell, 1965, p.975; Meyer, 1983a, p.239; Meyer \& Rowan, 1978, p.81; Meyer \& Rowan, 1983, p.73).

Even though, in an overall sense, educational organlzations are characterlzed by lack of control and loose coupling, universitjes may exhibit some very tightly organlzed parts which may be completely bureaucratic, while at the same time keeping communities of self-governing academlcians. These communities or groups are not necessarily entirely without relationship to each other. Some of these groups may be connected into recognizable or meaningful groups or departments. "The varlous departments concerned with physical health, for example, express their unity in their proximate physlcal location...other clusters...having bulldings...such as engineering" (Gross \& Grambsch, 1974, p.6). A college or university may have difflculty proving that their graduates have been well taught but may well be able to show that its cafeteria servlce is cost-effectlve (Bolman \& Deal, 1984, p.149).

Tight coupling, then, does occur within the educational organization. It usually occurs when the organization tries to maintain its agreed upon function of defining the societal myths surrounding the institutional rules for hlgher education. These rules define the ritual 
classiflcations: teacher, student, curricular toplc, and type of school. There are varlous levels of teachers: elementary, high school and college. Each level has its own specifications, categorles of speciallsts, and credentials. Student classiflcations are tightly controlled. Students are separated by level or grade, units or programs completed, major area of speciallzatlon, and by special abilities. Each Institution has its own set of curricular toplcs. These toplcs are organlzed in the university and assigned to professors, students, space, and funds. Finally, the professors, students, and toplcs are arranged into formal units by a precise and very elaborate set of rules (Meyer \& Rowan, 1978, p.84; Meyer \& Rowan, 1983, p.76; Welck, 1982a, p.673). Tight coupling also occurs between the educational organization and its environment. Whlle, unlversities are characterized as loosely coupled systems, its is their conformity to broad institutional rules ce.g. accreditations that links the institution to the environment (Meyer, 1983a, p.239; Meyer, 1983b, p.183).

Although linked tightly to certain aspects of their environments, it is the university's inherent looseness that allows the organization to respond more effectively than tightly coupled organizations to the surrounding environment pressures and changes (Meyer \& Rowan, 1978, p.105; Meyer \& Rowan, 1983, p.93). Thls more sensitive response to the environment may in fact be due to the loosely coupled nature of the organization, allowing the separate units within the institution to pursue contradictory and unrelated programs. 
It is these programs that make the university more responsive to its environment (Meyer, Scott, \& Deal, 1983, p.59). Welck (1982a) feels that there is a risk involved in the loosely coupled system as that individuals within the organization become captives of local groups because of the organizations response to the environment. Thus, the system can make increasing accommodations to the personal interests of outside groups undercutting the educational aims of the organization. He states, though, that thls is many times more formative than substantive. In actuality, the educational organization becomes buffered, and therefore unmodifled, from the community because of 1 ts characteristics of loose coupling (p.673-676). Thus, decoupling seems to be very effective for organizations that are located in environments that impose conflicting requirements of it (Scott, 1981, p.256).

THE EDUCATIONAL ORGANIZATION AND THE ENVIRONMENT

Educatlonal organlzatlons are hlghly responsive to the ir local environments and the demands that these environments make upon them. The organization attempts to retain a high level of support and legitimacy by linking itself with the surrounding community. The institution is constantly creating and renewing elements that will further reinforce this linking process (Meyer et al., 1983, p.55). Meyer and Rowan ( 1978 \& 1983) feel that educational organizations are more responsive because they are buffered from their own internal technical activity. Thls enviconmental position 
allows internal and external constltuent groups to perceive that they have more power in the institution than is true in const ituent groups in other types of organlzations <p.105; p.93). It is these external forces that Baldrldge (1977) states that can make revolutionary changes in the organization (p.129).

But education organizations do not just respond to local environments. Like most organlzatlons they are embedded in a much larger system of environmental relat lonshlps. Five of the most commonly observed levels of organlzational unit development are: national or society wide offices and associations, regional or multistate agencles and assoclations, state offlces and assoclations, area wide district offices and counclls, and local units and branch offices. Interestingly, Scott and Meyer (1983) further feel that organizations carrying out those activities at the local level would become more complex organizations because they reflect their more complex environments (pp.142-150).

Bennis and Nannus (1985) have trled to clarify the complex environment of modern organizations. They have divided the organizational environment into primary and secondary environments. It is their contention that "the organlzation itself chooses all of the primary environments and many of the secondary environments with whlch it must deal... In fact, the positioning decisions of an organization are very much concerned with the deslan of an appropriate niche" (p.158). An analysis of academic governance in the 
higher education system of the Unlted States seems to support this contention of the organization choosing its environment.

There are many dlfferent institutional forms, different sets of environmental pressures, different professional conflgurations, and different goals...examples...major universities, community colleges, medical schools, technical schools, ingtitutions with graduate schools, llberal arts colleges, massive multiversities, proprletary business schools (Baldridge, Curtls, Ecker, \& Riley, 1977b, p.42).

Diversity, then, seems to be the earmark of modern higher education organizations. This diversity has not been Just ldentified between organizations but has also been increasing within institutions. Perhaps the increased size of universities have been the main reason for the increased internal diversity (Baldridge et al, 1977b, p.47). Meyer and Rowan (1983) seem to feel that the diversity seen is because that part of an organization can respond relatively independently to its environment (p.94). In a study reported by Scott $(1981)$, It was found that the structure of an organization was altered by creating separate departments to confront the diversity in the environment. It was also found that the more differentlated the organization's departments were, the more likely conflicts and disagreements would develop and the more difficult it was to integrate and coordinate the work (p.247). 
Although there have been a few theorists that have taken speciflc note of organizational environment, most organizational theorists have spent little time or attention studying the relations between organizations and their environments (Baldridge, 1971, p.124). There have been a few that have proposed theorles or models that try to more clearly bring together the organlzational behavior and structure the environment. The soclal-learning theory model states that the changing external environment and the specific institutional environment are prime determinants of the behaviors that cause effective school performance (MartInko \& Gardner, 1984, p.145). The natural selection model emphasizes that the soclal organlzatlons move toward a better fit with their environment. This environmental perspective, then, posits that the factors in the environment chooses those organizational characteristics that best fit the environment (Aldrich \& Pfeffer, 1976, p.79). The resource dependence model proposes that organlzations are not able to internally produce all the resources or functions required to maintain themselves. Therefore, they must embark into relations and transactions wlth the environment to supply these needed resources and gervices (Aldrlch \& Pfeffer, 1976, p.83). Scott \& Meyer (1983) propose an alternate version of the Interorganlzational fleld model. The organizational field model stresses horizontal connections among groups of organizations in a limited geographlc area. These authors propose that contemporary organizations are connected to and 
affected by connections that emphasize vertical and extralocal relationships among organizations (p.131). Finally, both in the closed and open systems vlew of organizations the systems are seen as encountering the environment at their boundarles (Meyer \& Rowan, 1978, p.109; Meyer \& Rowan, 1983, p.96). The organization is seen as having a continuous serles of relationships between the organization and its environment. Basic to this approach are the ideas of suprasystem and subsystem (Abbott, 1975 , p.176).

Scott (1983) feels that it is necessary to distinguish three classes of elements in order to make a useful assessment of organizational environments: network, cultural, and historical elements. Organizations are affected by the structure of the relationships of interorganizational systems and by the societal system with In which they are located. These relational connections between organizations conslst of network elements expressed as $f$ lows or 1 inkages and are best described by their shared particlpants. The historical elements help increase organizatlonal understanding by calling attention to the relevance of past events in order to better comprehend the present and future of the organlzation. The author differentiates between three environmental levels: interorganizational fleld, societal, world-system contexts. Further, Scott (1983) states that the social and cultural environment of an organization can shape the organizational activities and structures as glgnificantly as 
Its technological environment. Stogdll1 (1971) takes this concept even further, when he states that when consldering organizational form and purpose, the social environment must be consldered a far more influentlal force than the physlcal environment $(p .41)$. Therefore, organizations can be regarded as an exchange agent of the environment. However, the author concedes that educational organizations seem to make more of an Impact on Its social system than the other way around (p.44). Evan (1971) states that because the organization is embedded in an environment it is in actuality a subsystem of the social system of soclety (p.175). It is this very unique soclal position of educational organlzations that would make it very difflcult to shield their activities from their environment. Educational organlzations are organlzations that are easily penetrated by their environments (Meyer et al, 1983, p.41). The environmental factor, then, is the relationshlp between the cllents of education and the organization itself (Carlson, 1975, p.188).

The author has examined both traditional and contemporary organlzational theory and the relationship of these theories to universities. Now revlew of literature will turn to athletics and examine both its place and role in the American university. 
V. ATHLETICS IN THE UNIVERSITY

Only in Amerlca has sport become an important part of the unlversity structure. In most countries around the world, athletics forms a very small part of the activities of the educational system (Chu, 1982, p.53; Sage, 1970, p.54). In this country, though, college athletics have evolved from an instltution that was universally opposed by educators in the nineteenth century to one that was tolerated as a necessary evil to a final stage at the turn of this century where it was recognized that athletics was something speclal and should be established as part of a comprehensive university program (Cozens, 1970, p.65). Given it special status within the curriculum, the American higher educational system has sponsored an Intensive program of spectator sports to explicitly train athletes for higher levels of competition (Naison, $1980, p .30$ ).

Athletics, as a distinctly Amerlcan institution, was incorporated into the formal structure of the university. Chu (1982) feels that this was the result of the diverse opinions that historically evolved concerning what is the proper curricula, programs, and resource acquisition procedures approprlate for a unlversity (p.56). Scott (1971) states, that the unique place that athletics has attained within the higher education system is because it is the only activity that serves as a basis of community on the individual campuses (p.169). Whatever the cause for its Incorporation, lacking a clear understanding of what exactly 
higher education is trying to accomplish, the development of a winning athletic program has become an important formal concern of universities (Chu, 1982, p.64).

In the $1980^{\prime} \mathrm{s}$, sclent if ic research and mass entertainment in sports have strengthened the dependency of major universities on public resources. Regardless of the institutions educational mission, universities have experienced financial constralnts that have Induced them to respond to the market forces Inherent in American soclety. As a result, the relationshlp between the university and the economic system has been fundamentally changed (Hart-Nibbrig 8 Cottingham, 1986, p.XII \& 76). Thus, this unclear understandling of the purpose of hlgher education has lead the business-minded leadership of the unlversities to use athletics as a financial survival mechanlam. Lack of guaranteed funding and other needed resources have forced business managers to look for other areas that might generate needed income. The enlargement of the athletic department offerings was one such vehicle for the acquisition of needed resources. The acquisition of funds and students through the intercollegiate athletic program may be seen as a diversification of the business of the university into new market areas within the American economy (Chu, 1982, p.53\&65\&64).

Key sports events glve a university opportunities to gain political resources. In connection with such events a university president may establish or strengthen ties to local politiclans, businessmen, 
alumnl, and other contacts in the community... As the university nurtures these contacts via sports events, the distinction between the university's values and corporate values diminishes, with the result that university and the business world become interdependent (Hart-Nibbrig \& Cottingham, 1986, p.75).

Thus, the interdependency between business and hlgher education has developed a new athleticism centered on business values and embedded into a new production system that has the capaclty to penetrate the surrounding society. Hart-Nlbbrig and Cottingham (1986) use the term corporate athleticlsm to refer to the influence of business values on this new athletlc system (p.14\& \& $)$.

Corporate athletlcism is the product of the decentralized adminlstrative structures in the universities and aggresslve, commercially or lented athletic departments. Wl thout these weak decentralized structures high power athletic departments could not have developed. However, corporate athleticism does not constitute an institutional distortion of the Amerlcan higher education system. On the contrary, this form of university athletics is the culmination of commercial trends that have been present in the university for a long perlod of time (Hart-Nibbrig \& Cottingham, 1986, p.115\&116).

Perhaps, though, the most signiflcant change in athletlcs at the collegiate level is that there is a new system with even stronger links to political and soclal forces outside the university. This new corporate form is 
both Inslde and outside the university. Because of this relationship, colleglate sports are no longer subject to or really controlled by those amateur norms hlstorlcally connected to higher education and collegiate athletics (Hart-Nibbrig \& Cottingham, 1986, P.XII \& 15). Being subject to these new social and business norms and forming strong relationships outside the university structure, perhaps athletlcs has developed new and unlque organizational structures in response to these nontraditional pressures.

Although not golng as far as saying that athletic departments have developed new organizational structures some authors have definitely referred to athletic organizations within the university as being so far from the educational framework that they remain not only functionally separate but are entities unto themselves (Hart-Nibbrig \& Cott Ingham, 1986, p.10; Mathews, 1972, p.420; Wolf, 1972, p.449).

In most cases, institutions following the semiprofessional model have developed administrative structures "separated" from the traditional academic organization of the university...(this) "semi-autonomous" character...gives athletic directors easy and special access to educational adminlstrators directly responsible for the financlal futures of the athletic departments; and needless to say, it allows for coordination and planning of presidential 
strategles and athletic department interests

(Hart-Nibbrig \& Cottingham, 1986, p.56)

Thus, it seems, the decentrallzed organizational structure Inherent in the unlversity helped facilitate the emergence of thls new form of athletics by allowing subunits within the organizational structure substantlal administrative autonomy.

This adminlstrative autonomy has allowed varlous subunits of the university to carry out speclalized educational misslons through developing relationships with outside groups. These relationships with commercial, government, Industrial and others have also been encouraged by the financial pressures due to the shrinking resource base of the university. Though many academic departments or units have developed varlous types of relatlonships with groups outside the university, it is the athletic department that has political autonomy that far exceeds the autonomy that can be achieved by the more traditional academic units of the university (Hart-Nlbbrig \& Cottingham, 1986, p.9).

Beslde providing political clout to the athletic department, these outside groups provide needed resources for the sports program. In 1969, the average contribution to athletic programs in higher education amounted to $5 \%$ of the athletic department's budget. In 1981, contributions represented $11 \%$ of the budget. Few Institutions would be able to break even if these contributions were not given in support of their athletlc budgets. But, those that provide these resources assume an informal control of institution's 
athletic departments. Thus, colleges and universities have given control of their athletic programs to groups outslde the university (Hart-Nibbrig \& Cottingham, 1986, p.60).

Although varied in make up, these outside groups form quasi-institutional interests that can be identified by their own indlvidual interests: parents, fans, alumn l and boosters. In most instances, it is the booster groups and their organlzations that are the most influential. Booster clubs reinforce the link between alumni and their school. They also provide a way, vlcarlously, for school supporters to develop contact with the institution of their cholce. Perhaps, though, the most important link the booster organization provides is the link between the athletic programs of the university and the business interests outside. Thus, athletics at the university is inextricably linked to thls business system (Frederlckson, 1969, p.95; Hart-Nibbrig \& Cottingham, 1986, p.78 \& $82 \& 90 \& 112 ;$ Sabo, $1980, p .76)$.

One group that can be sald to have quasi-institutional interest but is not linked to the booster groups is the National Colleglate Athletic Association (NCAA). The universitles used the NCAA to achieve their economic and athletlc goals. In return, American colleges and universitles glve the NCAA control over major internal functions (Stern, 1979, p.263).

In effect, the NCAA enabled universities to integrate college sports into a new system of cultural production and mass entertainment by helping them to amass 
financial resources and to distribute such resources among NCAA member institutlons (Hart-Nibbrig, 1986 , p.99).

Originally, the NCAA was not interested in amassing financial resources or controlling mass entertainment. The NCAA can trace its beginning to the administration of Theodore Roosevelt. In 1905, Presldent Roosevelt called representatives of Harvard, Yale and Princeton to the White House to dlscuss what could be done to stop the serlous deaths and Injurles that were occurring in the game of college football. Thus, although competition is at the center of Amerlcan soclety, it was far from the minds of the founders of the NCAA (Falla, 1981, p.203 \& 176).

In the beginning, the NCAA membership was mainly made up of scholars and educators. As an organization, then, it stressed high academic standards for institutions. For the athletes the NCAA stressed the pursult of a full schedule of academic work (Falla, 1981, p.143). By 1918, the NCAA began to broaden its involvement in colleglate sports and in the Internal organizational structure of its members. For example, the Assoclation passed the following resolution during its 13 th convention:

...that every college and university, the Department of Physical Training and Athletics should be recognized as a department of collegiate instruction, directly responsible to the college or university administration ...a corollary to which is the suggestion that coaches be made year-around staff or faculty members... lift 
athletics (to)...the level of cocurricular activity (Falla, 1981, p.55).

This involvement transformed the NCAA from a loose confederation of voluntary university members into a control agent that dominated intercolleglate athletlcs (stern, 1979 , p.242).

By 1951 , the control that the NCAA exerted over intercolleglate athletlcs became more formally established. A cartel agreement was granted that gave the NCAA the authorlty to enforce rules of amateurlim over 1 ts member colleges (Stern,1979, p.242; Stern, 1981, p.17). As a private regulatory system, the NCAA established itself as a control agent in order to maintaln and produce standards of performance, to alter competition, to control entry, and to prevent government intervention. It also directed champlonship events and television coverage of 1 ts contests. The revenue generated from these activities is allocated by the NCAA according to association bylaws (stern, 1981, p17).

It was also in the $1950^{\prime} 3$ that the NCAA began to do "more to communlcate to the general public and to the college community the full impact of intercollegiate athletics" (Falla, 1981, p.222). It was the NCAA's job to communicate to the public the perception that college athletics retained important values inherent in an amateur activity: falrness, honesty, and discipilne cHart-Nibbrig \& Cottingham, 1986, p.96). Trying to maintain its commitment to amateur athletics and at the same time fulflll the needs of those institutions that wanted to increase their 
grants-in-alds to its student-athletes, in 1973 the NCAA completed a flnal allgnment of conferences. It showed that 237 of its member ingtitutions chose to be in Division I, 194 choosing Division II, and 233 choosing Division III (Falla, 1981, p.233).

The first real crack in the control exerted by the NCAA over colleglate athletics occurred in 1981 when 63 large football playlng institutions jolned together and formed the College Football Association (CFA). The purpose of this new association was to get a larger share of the television money that their teams were generating. In response, the NCAA held a special convention and split Division I into Division I-A (for the football powers) and Division I-AA (Smith, 1984, p.H-1). As Wolf (1972) had suggested, this action shows how the NCAA is controlled and run by the athletlc departments of the big-time sports institutions. Thls ls true even though the majorlty of the membership of the NCAA is made up of small schools which operate on a $1 \mathrm{imited}$ or nonathletic scholarship basis (p.448).

Although many groups have tried to challenge the authority of the NCAA to control colleglate athletics, the NCAA has been successful in meeting the challenge. The federal government, as an outside interest group, both has protected and challenged the NCAA's right to control athletics at the collegiate level. As stated previously, the very ldea for a national organization was instltuted by the executive branch of the federal government. By 1919 , the federal government again stepped in to protect 
collegiate athletics. It revised the recently passed revenue laws in order to abolish the Federal tax on admission to intercollegiate contests (Falla, 1981, p.204). Again in 1954, this exemption was reinforced when Presldent Dwight D. Elsenhower slgned a new Federal excise tax bill providing for a new Federal admissions tax:

The Federal admissions tax shall not apply in the case of any athletic event between educational institutions held during the regular athletic season for such event, if the proceeds therefrom Insure exclusively to the benefit of such Institutions (Falla, 1981, p.207). Again in 1962, the NCAA recelved additional government protection and support when the United Stated Senate enacted a law making it a Federal offense to offer a bribe in order to influence the outcome of an athletic contest (Falla. 1981, p.208).

Thls mutual and supportlve relatlonshlp between the federal government and the colleges contlnued into the 1960 's and 1970 's. One of the strongest bills to be passed during this perlod averted the competition from elther filmed or live professional football on any Saturday during the colleglate football season. Interestingly, the committee reasons for pushing passage of the legislation went beyond the simple task of eliminating competition between two groups of football antagonists. "It is particularly gratifying to the Television Committee...to note this undeniable evidence of realization by the Congress 
of the United States that college football is an asset to the country warranting preservation" (Falla, 1981, p.113).

In 1981, Individual members of the NCAA turned to another branch of the Federal government to challenge to right of the assoclation to control what they belleved was their right to negotiate their own institution's television contracts. The UnIversity of Georgia and University of OKlahoma sued the NCAA because it prohlbited individual schools from negotlating. At stake, if the sult was to be won by these schools, were contacts between the NCAA and ABC and CBS television networks worth some \$263.5-million over four years. The courts ruled that the NCAA restrlctions constituted an 11 legal monopoly (Vance, 1984, p.27).

Although it has been only in recent years that the NCAA has been able to generate large amounts of revenue, throughout most of its history the NCAA's strength was not In the wealth it generated but rather in the influence it was able to exert. It took forty-one years (1906-1947) for the Assoclation's general revenue to exceed $\$ 100,000$. Beginning in the $1950 \mathrm{~s}$ and through the 1970s, the NCAA saw an ever-accelerating flow of revenue. In 1967 the Assoclation's general revenue exceeded the $\$ 500,000$ mark. Four years later (1971) NCAA revenues topped the $\$ 1$-million mark for the first time. After seventy-five years, what would have surprised the founders most is that only one percent of the $\$ 22,429,000$ in the NCAA's annual budget came from members dues (Falla, 1981, p.217 \& 288). 
The previously discussed historical data suggests that one of the maln reasons the NCAA was able to increase its dominance over intercolleglate athletics and control the ever increasing revenues was because of system coupling. The critlcal issue in respect to system coupling was the degree in which the NCAA was able to monitor and control the athletic programs of its member schools. Coupling is varied due to the mechanlsms the Assoclation used to attempt to influence the athletic programs of it members. Loose coupling occurred due to the Associations policy of local autonomy. Because of local autonomy, the NCAA was not only able to reduce the cost of administrating its programs but also needed little coordination of them. Unafflliated schools were linked to this network only by following the NCAA rules of play for all the contests they conducted. With respect to system coupling, the power that the NCAA exerted emerged through the tightening of network linkages. An example of this tight coupling is the enforcement procedures involving rule violations. These decisions represented the extreme tightening of the athletic network, and gave the NCAA a formalized dominant position cstern, 1979, p. 254-255).

The NCAA retained the symbol ic vestlges of amateurism, and the norms of amateurism, helped legitimize the transformation of college sports far beyond its amateur foundations... A whole series of NCAA actionsredshirting, more competitive recruiting, more athletic scholarships, weak enforcement procedures, the passage 
of freshman eligiblilty, and the acceptable lax standards for athletes- all helped university sports programs to give greater scope to dynamic market forces (Hart-Nibbrig \& Cottingham, 1986, p.97).

Also alding the influence of the market forces on the athletlc programs was the weak and 111-defined charter of Amerlcan higher education. Without a strong consensus from the American people, the purpose of the university was open to the needs and desires of America's lnstitutions of higher learning and their constituents. This charter, though, was not a written document. Rather. It was an informal understanding. It told the people what they should expect from the entity known as a college or unlversity. The charter was the result of contemporary and historlcal attitudes, values, goals, and dreams of society. Because of society and this weak charter, an atmosphere was created that allowed radlcally different programs to be Incorporated into the academic structures of the universities (Chu, 1982, p.54).

\section{ATHLETICS IN AMERICA}

...sport teams as small social systems can be viewed as microcosms of larger social systems, including soclety itself. They present in minlature such socletal features as division of labor, a code of ethlcs, a government, means of communication, prestlge rankings, ldeologies, myths, and even religious practlces (Loy, 1972, p.79). 
The sclentific ingulry of the soclology of sport is a falrly recent addition to those experts who study American soclety ( Daniels, 1969, p.13). Sports permeates the many different levels of society. It influences such elements of contemporary society as status, business life, race relations, clothing styles, automotive design, the concept of hero, ethical values, and language. For better or for worse, athletics gives the very form and substance to much In modern American 11 fe (Edwards, 1976, p.21). Chu (1982) feels that it is through sport that present day culture can possibly soclalize its diverse population to accept the same norms of thought and behavior $(p, 63)$.

Culture is learned. The learning takes place through the encountering of new experiences (Schein, 1985, p.8). It is through sport that this learning takes place. Sports and athletics are activities that belong with the arts of humanity. They are the expressions of human life. In this sense, sports and athletics are as fundamental a form of expression as music, poetry, and painting. They are the very essence of social cooperation (Daniels, 1969, p.15; Erbach, 1969, p.30; Frederlckson, 1969, p.92).

Hart-Nibbrig \& Cottingham (1986) state that, as a cultural norm of modern soclety, athleticlsm grows out of the need to experience declsive outcomes. Because of the complexity inherent in contemporary soclety, sports is one of the few soclal domains in whlch conflict can produce closure. In an athletic contest the rules are such that there are clearly established winners and losers. There is 
no compromise. It is striving for and achleving success. Success, as measured by winning, has deep roots in Amerlcan soclety $(p .98)$.

Cultural analysis of a society is a matter of determining the interconnections and independencles that exist within the soclety (Welck, 1977, p.212). Beslde being able to produce declsive outcomes, other authors feel that athletics also provides other interconnectlons and independencies within American culture. Chu (1982) states that intercolleglate sport is a necessary unlfying vehicle because of the diversity inherent in the American population (p.63). Belsser (1970) asserts that sports are one of the last places where physical aggression has an established location in our culture. Through sports, the aggression so applauded by present day society is able to be channelled into accepted behavior patterns (p.241). Frederlckson (1969) feels that any cursory review of sports and their place in the culture of man will reveal their importance of ritual within their structure. As an example he gives the singing of the Star-Spangled Banner before athletic contests as an attempt to attribute some intensely nationalistic omen to the event $(p .95)$.

Other researchers go one step further in feeling that sport should not only be vlewed as just providing interconnections and interdependencies for soclety but should also be seen as a subculture or soclal system within Amerlcan culture. As a subculture, sport may be characterized by a distinguishing pattern of values and 
norms, a collectlve ldentlty, a set of rules, and having an Implicit ldeology (Loy \& Kenyon, 1969a, p.349; Luschen, 1972, p.70; Phllllps \& Schafer, 1976, p.128). Sport, then, is primarliy a cultural product (Frederickson, 1969, p.90). In this sense, intercollegiate sports not only connects the unlversity to mass soclety but also to the evolving culture and values of that mass society cHart-Nibbrig \& Cottingham, 1986, p.83). Thus, to truly understand sport as a subculture it is necessary to grasp its relat lonships to the surrounding and domlnant culture (YInger, 1960, p.629).

Culture has played a significant role in the development of intercolleglate sports in the Unlted States. Athletics has been Influenced most directly by two historical tradltions that are embedded within American culture: the British tradition of sports which emphasizes the use of sport to inculcate athletes with moral character and the Spartan tradition whlch uses sport as a preparation for the military (Scott, 1971, p.175).

There is no question about the effect whlch various aspects of WWI had on sports in schools and colleges during the years between World Wars I and II. The emphasis placed upon sports as a most valuable preparation for conditioning and morale of soldiers, the tremendous spectator interest developed in France as a result of the sports competition placed before the armed forces during and after WWI, the Indlgnation of the people at home in regard to the physlcal unfitness of draftees- all of these became pressures in American 
culture to set the stage for the great boom in sports participation and interest whlch developed in the nineteen-twenties (Cozens, $1970, p .70$ ).

Owing to this increased interest, a public demand was created that lead to the erection of huge stadlums on the campuses of many American universities. In fact, during the depression a considerable share of WPA and PWA funds were used on erecting athletic sports facilities- gymnasiums, tennis courts, swimming pools, and athletic fields. By 1937. \$75,000,000 had been spent on these projects (Cozens, 1970, p.710).

Two classes of instltutions emerged from this growth period. The first was known as the university division schools. These colleges had more students, commanded more resources, and had a greater need to win. This need was caused by the necessity of attracting the revenue brought by fans watching winning teams and the success that ensued. The other division included those colleges that wanted to win but had fewer athletes. These institutions hoped to attract good athletes but wished to participaie in athletics for the values obtalned through competition rather than for the revenue they could produce (Stern, 1979, p.250).

These approaches worked beautlfully unt ll the post-WWII sports hysterla that began to make itself felt on certain athletlc programs. It was at this time that football became central to the generation of revenue for those unlversities that wished to pursue winning as their primary goal. As these institutions competed for an increase share of the 
fInanclal resources they soon discovered that there were not enough good athletes to go around. The market force of supply and demand entered into the plcture and the whole intercolleglate athletic system was thrown into turmoll.

As Gall1co (1970) states, "the puzzle st1ll remains as to why the unlversities, reputedly the fountaln-head of the country's ethlcs, brains, and culture, were unable to meet these new conditlons as honestly and successfully as they had met other not disgimilar problems" (p.112). Thus, on one level, intercolleglate athletics was perceived as an educational endeavor because of 1 ts location in American colleges and unlversities and on the other it was Indirectly and directly influenced by specialized economic and political interests ( Hart-Nibbrig \& Cottingham, 1986, p.82).

In the $1960^{\prime} s$ and 1970 's many unlversitles granted substantial control of their sports programs to their own semiautonomous athletic departments. Therefore, these Institutions allowed well organlzed interest groups to control the direction that these department began to take (Hart-Nibbrig \& Cottingham, 1986, p.97). In the 1980's, American universities crossed another institutional threshold in respect to athletics. They became less insulated from a greater varlety of cultural forces. If Hart-Nibbrig and Cottingham (1986) are correct with this analysis, the multifunctional role of the university will be enlarged. Thus, the market forces introduced a new system of stratification. Thls stratification is caused by the 
connection between the sports markets and the university. The authors argue that universitles have Internallzed market criterla through the role specialization of the student-athlete and through the corporate athletic Infrastructure being Institutionalized within the unlversity (p.112).

To declare that sport, during the pregent century, has become a cultural phenomenon of great magnltude and complexity is an affirmation of the obvious... Its scope is awesome; nearly everyone has become involved in some way, even if only vicariously. As a business enterprise alone it represents an annual expendlture by the American public of over \&20 billion CLoy \& Kenyon, $1969 b, P .36)$.

Thus, a variety of economic and social events occurred within the American culture which created an environment that influenced the development of intercolleglate athletics and its athletic network. Because of the changes in the environment, two general effects arose whlch influenced the athletic network development. The most obvlous was the increased interdependence caused by technological changes, increasing affluence, government, and public interest in intercollegiate athletics. Second, the effect of environment on the nation's colleges and universities. These factors altered the very nature of collegiate athletics in this country (Stern, 1979, p.248 \& 250).

The technological changes within the environment centered around the increased effect of the mass media in 
this country. As Snyder (1976) states, "sport is so much a part of the cultural alr through mass media and conversation that one cannot be totally insulated from its influence" (p.5). Athletics in present day mass society functions as an integrating symbol for Amerlcan culture. Sport, as presented on television, is not only an integrating symbol but is also a life-giving symbol. Since traditional symbols have lost much of thelr content in many of the advanced Industrial socleties like the United States, athletics has become a more clear symbol of mass culture (Hart-Nibbrig \& Cottingham, 1986, p.49).

This symbolic relationship between athletics and mass media can be best lllustrated by the large amount of air time devoted to sport on American television (Sabro, 1980 , p.162). Because of this media blitz, television, not higher education in the United States, is the ultimate producer of intercolleglate athletics. Television, therefore, creates the perceptions that define athletic standards. In fact, television even seems to make it difficult for viewers to discern the difference between myth and reallty. Sports is one of the few areas in people's lives where heroes come to IIfe (Hart-Nibbrig \& Cottingham, 1986, P.34 \& 48).

A highly decentrallzed sports system of massive scope is now evolving in the United States. It is a total sports system, characterized by top-to-bottom integration of the corporate television system and Intermediary social structures. The sports television market induces al' intermediary structures- 
unlversitles, boosters, and highly competitive famll les- to serve market ends (Hart-Nibbrig \& Cottingham, 1986, p.13).

As previously discussed in this review, hugh amounts of money have been generated for the athletlc departments due to their television contracts. The increased revenue and affluence for the participating programs and their Institutions have been caused by the environment. Thus, the environmental change modifled intercolleglate athletics.

In retrospect, Hart-Nibbrig and Cott Ingham (1986) feel as Institutional affluence increased, presidential control over the indlvidual school's athletic program steadlly weakened and athletic interests increased their resistance to that control (p.94). Farrell (September, 1984) also states that much of the blame for the current rules violations must be placed on television and the large amounts of money it pays schools with winning teams (p.29). Whether this effect television has had on intercollegiate athletics will change is doubtful. It has been estimated that $90 \%$ of future revenue will be generated by Intercolleglate teams competing on television cHart-Nibbrig 8. Cottingham, 1986, p.69).

Another environmental change was the effect of the government on the athletic programs in higher education. As previously discussed, the government has played a protectlve and influential cole in the creation and development of the NCAA and intercolleglate athletlcs. Recently, however, the federal government interventions have provided institutions 
with big-time programs a mechanism for loosening the independent power of the NCAA that the government had helped to create. These dominant schools do not want to follow NCAA guldelines and share their revenue with less wealthy schools. With a favorable rulling from the Judlclal branch of the Federal Government, it was ruled that revenue from activities such as televised contests are outside the NCAA controls (Stern, 1981, p.27). Local governments have also alded in changing athletics by the extensive bldding that now goes on for the privilege of some city hosting a top NCAA champlonship. As an example, the city of Denver pledged $\$ 557,500$ worth of Improvements to its municipal sports arena if it was able to hold the 1989 Basketball Champlonships (San Diego Union, 1984, p.D-11).

Public interests is probably at the botton of many of the environmental changes brought about in intercollegiate athletics. Sports occupy a unique position in American culture in that they are an accepted social activity regardless of soclal class (Beisser, 1970, p.242). Athletics fascinate the American public. In order to satisfy this public interest most dally newspapers devote more space to athletics than they do to art, books, education, television, or theater (Boyle, 1970, p.42). Goodhart and Chataway (1968) state that this Increased national passion for sport can be seen as a commentary on the inadequacy of modern society. Because millions of people are not involved with the present-day society in whlch they live and work, they achleve some level of 
satisfaction by passionately ldentifying with the particlpants of some sport ritual. The authors further feel that as work becomes less satisfying the ranks of these spectators are sure to grow (p.156). As the average person increases their interest and excitement for sport, sport approaches a religion in the United States today (Scott, 1971, p.170).

It is not merely like a religion...sport can and does provide its followers everything that traditional religions have provided over the centuries...many of the trapplings of religion that sports has, such as myths, legends, and rituals...sport can be used to teach values such as honesty, fair play, compassion, and discipline... it is not just a parallel that is emerging between sport and religlon, but rather a comelete identity. Sport is rellalon for a growing number of Amerlcans (Vance, 1984, p.25).

Other authors also feel that athletlcs have achleved a status of a religion to many people in America today. Vance (1984) acknowledges that sport is not necessarily a religion to all people. It is a religion, though, to those spectators and athletes that rely on sports to ald them to feel the ultimate experience; and, whose lives, attitudes, personal relationshlps, and values are radically changed by this experlence $(p .26)$. Edwards (1976) also states that sport provides the ultimate experlence for its followers. However, he feels that although sport is strongly marked by, "nonutllitarian loyalties and commitments, by much 
ritualized or ceremonial behavior, by expressive symbolism, and ldeologlcal creeds...sport ls essentially a secular, guasi-religlous institution" (p.21).

One of the strongest symbols in colleglate athletics today is the concept of amateurism. Although it no longer plays any real part in college sports, the American public retains a strong symbolic attachment to the concept that college contests have not been changed by the commercial values that surround it. In other words, amateurism softens the commercial edges of intercollegiate athletics (Hart-Nibbrig \& CottIngham, 1986, p.108).

This, then, is the environment that surrounds the university and its sports program. Therefore, as an organization the university is subjected to a great varlety of cultural constraints. Stodgll (1971) states that because of these constraints imposed by the cultural environment, the purpose and structure of the organization may be determined by the culture in which the organization is a part. Members take outside societal values and bring them into the organization. The organization creates at least some minimum change in these values before they are returned to the surroundling environment $(p .49)$. It seems, then, that the environment created by American culture may not only change the collegiate athletics program but the university in whlch it is lacated.

One example of environmental change is the effect of having an athletic program on the prestige of university itself. It is clear that the more highly visible and 
successful the institution's athletic program is the more prestlge the university is perceived in having lMcCurdy, 1984). Winning and success then, seems, to become as important as other more academic activities in providing the aura of prestige for an institution. Winning teams also provide an activity that helps the general public identify with the university (Hart-Nlbbrig \& Cottingham, 1986, p.97). Winning programs are also more flnanclally secure programs (Vance, September 1984, p.30).

After all, the theory behlnd the system is that successful (translate: winning) teams, especially in the revenue producing sports of football and basketball, can do all kinds of wondrous things for the institution of higher learning. Winning teams can mean increases in gate recelpts, television contracts, alumni donations, university budgets and community acceptance. In such a system, winning is necessary...(Wolf, 1972, p.449).

This ambivalence between educational prestige and winning is probably one of the main cultural legacies that seems not to be able to be resolved to everyone's satisfaction. It repregents, though, the country's own amblvalence toward how it feels about high-powered colleglate athletics (Glamatti, $1981, p .81$ ).

Another example of environmental change, is the effect of external institutions, like business and government, on the university and its athletic program. Changing economic conditions caused by these entities effect all aspects of 
the American way of life. Colleges and unlversitles are no exception. These institutions are forced to make careful cholces based on change within the surrounding economic environment. Examples of these cholces are: faculty tenure, matters of student access, and all resource allocation issues. As change quickens within this external economic environment market forceg are integrated within the university. Choices for resource allocation are, thus, based on economic rationality or demand criterla. Accordingly, as cholces for resource allocation are made within the athletic program, funds are shifted away from the non moneymaking activities and glven to the moneymaking sports. Thus, the cultural environment reinforces the strength of the economic forces in the management of the sports programs (Hart-Nibbrig \& Cottingham, 1986, p.76).

Thus, because of culture, buslness methods have become an integral part of the way the athletic department conducts its business. It was rationallzed by the college leadership that the use of these methods was necessary to not only for a good public image but in order to pursue success and excellence (Chu, 1982, P.64).

In the United States great emphasis is placed of "success" and the struggle for status. Since sport is such a prominent feature of American life, and since by Its very nature it represents a struggle for dominance and physical superiority, it is not surprising that sport has become the primary avenue to group status for the American male...Achlevers are esteemed, and 
proficlency in sport skllis seen as achlevement in Amer lca (Sage, 1970, p.121).

Success and excellence in sport focuses attention upon the presentation of hlgh-quallty performance. The quallty of performance is as much a social concern as an instjtutional concern. A system of shared values orlented to both the institution of athletics and the larger soclety combine to attract and keep widespread public interest and attention (Edwards, 1976, p.210). Because of this societal need to see who is really the best, numerous performance measures exlst. The one directly comparable measure of the performance of major competitors is the national ranking system (Stern, 1981, p.22).

The cultural induced focus on excel lence has brought about other changes within the athletic organlzation and its programs. Hoffman and Stein (1980) found that the demand for high-level performance is so pronounced that many athletes wlll play with great paln, risking further serlous injury (p.70). The search for excellence has also affected the coaching profession. Although in the past coaches were part of the regular university faculty, they now have been removed from this institutional structure. The coach is hired for one purpose- to win. If the coach does not produce a winning team he/she will be fired (Gallico, 1970, p.120).

It seems, then, that the only acceptable solutions for sports performance is excel lence as demonstrated by a high level of success. The value placed on success, excellence, 
and the competitive nature of athletics seems to be a reflection of basic values inherent in Amerlcan soclety. Sport is an American social Institution which has the primary functlons of disseminating and reinforcing values and behavior and determining acceptable solutions in the secular sphere of $11 \mathrm{fe}$. "Hence, an attack upon sport constitutes an attack upon the society itself...this Interpretation is affirmed by persons supportive and critlcal of the functioning of sport in America" CEdwards, $1976, \mathbf{p} .212$.

VII. EXCELLENCE AND HIGH PEREORMANCE

Although excellence and high performance are basic to any discussion on athletics both within American culture and within the American unlversity, these issues have rarely been addressed by any study completed on American institutions of higher education. In the business world, though, researchers have begun to study high performance and excellence as characteristlcs of some companies. Two models have been developed involving high-performance.

The first model has been developed by Valll (1982 \& 1984). Thls model illustrates the High-Performance system Model. Valll has defined high-performance systems as any organlzation or group that meets one of the following criterla:

1. They are performing excellently agalnst a known external standard. 
2. They are performing excellently against what is assumed to be their potentlal level of performance.

3. They are performing excellently relative to where they were at some earlier point in time.

4. They are judged qualitatively by informed observers to be dolng substantially better than other comparable systems.

5. They are doing whatever they do with signiflcantly fewer resources than it is assumed are needed to do what they do.

6. They are percelved as exemplars of the way to do whatever they do, and thus become a source of ideas and insplration for others.

7. They are percelved to fulfill at a high level the ldeas of the culture within which they exist.

8. They are the only organlzations who have been able to do what they do at all, even though it might seem that what they do is not that difflcult or mysterious a thing (Vall1, 1984, p.86).

Valll found that the high-performance systems (HPS) have the following characterlstics:

1. HPSs are clear on their broad purposes and on nearer term objectives for fulfilling these purposes.

2. Commitment to these purposes is never perfunctory although it is often expressed laconically. Motivation as usually conceived is always $h$ lgh.

3. Teamwork in HPSs is focused on the task.

4. Leadership in HPSs is strong and clear. 
5. HPSs are fertile sources of inventions and new methods within the scope of the task they have defined and within the form they have chosen.

6. HPSs are clearly bounded from their environments, and a conslderable amount of energy, particularly on the part of leaders, is usually devoted to maintaining these boundarles.

7. Proposition (6) leads to another consistent finding, that is that HPSs are often seen as a "problem" by entities in their environment, even entities which have a great deal of power over them. 8. Above all, HPSs are systems which have jelled, even though the phenomenon is very difficult to talk about (Vail), 1984, pp.86-88).

The second model, is the High Performance Programming (HPP) model. This model illustrates how an organization can be transformed into a hlgh-performing system. The author uses the term programing to highlight the fact that past implicit and explicit operating instructions of the system directly effect the present performance of the system (Nelson, 1984, p.226).

While these models involve hlgh performance as the central theoretical bases, impliclt within each model is the theor lsts' view that excellence in performance is a standard feature of high performing systems. Although Peters and Waterman (1982) did not study high performance per se, they did study excellence in companles that far outperformed their underachleving competitors. The authors focused their 
attention on the relationship between a company's culture and performance. The results of the study supported the authors' contention that excellent companies produce results through their strong, cohesive cultures. They found elght attributes that characterlzed excellent and high-performing companles:

1. A blas for action, for getting on with it.

2. Close to the custamer. These companies learn from the people they serve.

3. Autonomy and entrepreneurship. The innovatlve companies foster many leaders and many innovators throughout the organization.

4. Productivity through people. The excellent companies treat the rank and file as the root source of quality and productivity gain.

5. Hands-on, value driven...the basic phllosophy of an organization has far more to do with its achlevements that do technological or economic resources, organizational structure, innovation and timing.

6. Stick to the knitting... Never acquire a business you don't know how to run.

7. Simple form, lean staff... The underlying structural forms and systems in the excellent companies are elegantly simple. Top-level staffs are lean...

8. Simultaneous loose-tlght properties. The excellent companies are both centrallzed and decentralized (p.14-15). 
Excellence and high performance appear to go hand-ln-hand. Valll's definition for hlgh performing systems seems to support this contention. High-performance systems refers to "human systems that perform at levels of excellence far beyond those of comparable systems" (Vaill, 1984, p.85 \& 1982, p.24). In high-performance systems, this focus on excellence is achleved by ldentifying new potentials and avenues of opportunity. To accomplish this a high energy level within the organization frees the human spirit to new levels of productivity. To the outsider this high level of energy appears, often times, to be chaotic and frenetic. Yet, to the people within the high-performance system everything seems quite normal (Nelson, 1984, p.236-238). Harrison (1984) states that studies of high-performing people, such as athletes, managers, researchers, suggest this energy can be characterized as a power of thought $(p .104)$.

other authors have also suggested other characterlstics of high-performing organizations. Bennis and Nannus (1985) state that these organizations try to learn as much as they can concerning their changing environment. By learning as much as possible the organization can develop a sense of purpose, direction, and desired future state (p.213). Lawrence (1967) feels that high-performing organizations come closer than their less effective competitors in meeting the demands of their environment. The author, also, states that high-performing organizations have many similarities in the way in which they resolve conflict. In the three 
organlzations that Lawrence studied, the organlzational mode of behavior used to resolve conflict relled heavily on open confrontation and open discussion which led to the optimal solution (p.134\& 146). Harrison (1984) warns, however, that high-performing organizations may have Inhumanities. The author suggests that these organizations can burn people out, control private lives, astracize those who do not share the common purpose and are frequently ruthless in all forms of dealings with those outside the organlzation (p.100). Peters and Austin (1985) note that flne performance in an organlzation occurs when the people at all levels pay close attention to organization's values, environment, and communlcation network and then develop skllis that will help them make a contribution to the company. The authors go on to state that this recasts the detached manager into an enthusiastic, dedicated coach (p.325).

Nelson (1984) feels that it is this attention and curlosity about the potentials of the organization and the people in it that provides the major clue about the nature of high-performing organizations and high-performing leaders. The kind of leadership required in this type of organization is what the author terms holistic. ..."hol ist ic," because high-performing leaders appreclate the larger roles played by their organizations as instruments of change in adjacent and hlgher systems in the environment. They look not only into their own organizations to help develop their potentials and that of their people, but to the outside 
as well...they use thelr organizations to make contributions to the human communities and the culture In whlch they reside (p.237-238).

It is from this holistle understanding of the organization that the leaders make their cholces about the organization's mission and purpose (Nelson, 1984, p.157).

VIII. THE ATHLETIC DILEMMA: HIGH PERFORMING SYSTEM OR ANARCHY?

The Unlversity is an organization that has been characterlzed as an organized anarchy and a loosely coupled system but in reality has defied classiflcation in terms of any particular model (Gross \& Grambsch, 1974, p.5). Cohen, March, and 01 sen (1972) acknowledge that the theory of organized anarchy describes a portion of an organizations activities but not all of them (p.1). Baldridge et al (1977a) state that by identifying the university organization as an organlzed anarchy suggests more confusion and conflict than really exist. The authors suggest that the term organized anarchy refers to speclfic organizational characteristlcs rather than to the entire university comnunity (p.8).

The difficulty in identifylng the university seems to be caused by the great amount of amblgulty that most educational organizations exhiblt. Bolman and Deal (1984) feel that the greatest amount of amblguity may be exhlbited where multiple cultures intersect (p.238). Perhaps the key to understanding and explaining this demonstrated ambiguity 
of university and collegiate organizations is to identify the multiple cultures included within the Institutions?

Organlzations have dist Inct cultures (Bolman \& Deal, 1984, p.29). Not enough attention, though, has been glven to the possibillty that organizations and groups within a society may also develop their own distlnguishing cultures. Schein (1985) asserts that in order to understand these organizational cultures correctly we must "understand why organlzations do some of the things they do and why leaders have some of the difflculties that they have" (p.3). Schein also states that the best way to accomplish this greater understanding is through empirical research:

Whether or not a given company has a single culture in addition to varlous subcultures then becomes an empirical question to be answered by locating stable groups within the company and determining the shared experiences of the members of the total organization. One may well find that there are several cultures operating within the larger social unit called the company or the organlzation: a managerial culture, various occupationally based cultures in functional unlts, group cultures based on geographlcal proximity, worker cultures based on shared hierarchlcal experlences, and so on (Schein, 1985, p.7). Perhaps, to better understand the Unlversity as an organization is to have research focus, as Schein suggests, on locating a stable group within the organization that 
perhaps demonstrates 1 ts own distinct lve cultural characterlstics.

Individuals within the higher education organlzation are usually grouped by common interest; for example, departments, colleges and schools, and university agencies (Millet, 1962, p.76). The links between these parts are "typlcally loose, so that each level performs its own activities and is substantially disconnected from the other levels" (Bolman \& Deal, 1984, p.34). Hart-Nibbrig and Cottingham (1986) state that because of the type of organizational connections between the varlous parts of the university the institution can adjust easlly to market demands (p.115). Increasing market pressures, though, makes the governance of colleges and unlversities more vulnerable to their environments (Baldridge et al., 1977a, p.19). Current research ldentifies the environment as one of the most powerful factors in influencing the structure of an organization (Bolman \& Deal, 1984, p.43). As the environment changes so does the formal structure of the organizat ion (Meyer \& Rowan, 1983, p.95). Baldridge (1971) states that educational organizations cannot react to all facets of their environments. Therefore, the organization relates to the environment through the small groups within the education institution (p.128).

Using this perspective, Hart-Nibbrig and Cottingham (1986) suggest that institutionalized political economy of athletics lllustrates the environmental pressures of the external environment. It is the authors belief that the 
unlversity sports program is more directly linked to the values of television and the mass-appeal of sports, than to the academic values of the unlversity. It is the search for the entertainment dollar and the success that must precede it that is the driving force of athletics in most institutions of higher learning (p.115 \& 9).

The questlons posed by thls research are, whether the two models that view the organizations as being an ambiguous, loasely coupled organlzation and as high performance systems are incompatible? or, can a high performance system exist within an ambiguous, loosely coupled system? In order to investigate these questions, various areas of the literature were reviewed: the traditional view of the unlversity, the contemporary view of the university: organlzed anarchy and loose coupling, the university as an organization, the educatlonal organization and the environment, athletics in the university, athletics In Amerlca, excellence and high performance, and the athletic dilema: high performing system or anarchy? Given this problem has been ldentified and a revlew of literature was completed, it is necessary now that this problem be examined empirically. 
CHAPTER I I I

METHODOLOGY

The methodology selected to investigate an example of a percelved high-performance system is the case study. This chapter contains a description of the methods and procedures used to conduct the case study. The information is presented under the following toplcs: the Case Study; Limitations of the Case Study Method; Limitations of the Study; the Sample; Interviews; Data Gathering; and Data Analysis.

THE CASE STUDY

In its simplest form, "the case study involves an investigator who makes a detalled examination of a single subject or group or phenomenon" (Borg \& Gall, 1983, p.488). simon goes beyond this simple definition of a case study when he states that:

case study...(is the) method of cholce when you want to obtain a wealth of detail about your subject... appropriate when you are trying to find clues and ideas for further research... in this respect, it serves a purpose similar to the clue-providing function of expert opinion $(1969, p .276)$.

92 
Yin (1984) supports much of what Simon states in his definition of a case study but elaborates on the definition by suggesting that a case study is a distinctive form of empirlcal research that:

-investigates a contemporary phenomenon within its real-life context; when

-the boundarles between phenomenon and context are not clearly evident; and in which -multiple sources of evidence are used (p.23). The case study, though, does not have to be 1 imited to a person, an enterprise, or a particular happening. It can be a study of any bounded system that is of interest to the researcher-- an institution, a responsibility, a collection, a program or a population (Stake, 1983, p.283).

The real value of using the case study method is that case studies have the potential for generating meaningful subjective data that can ald the researcher in the development of theory and empirically testable hypotheses (Borg \& Gall, 1983, p.489). In fact, Yin (1984) states that one of the main rational for selecting a single-case rather than a multiple-case design is that a single-case study can be used as a critical test for developing signiflcant theory (p. 42).

Other reasons for using a case study as a research method are: it can provide an important way to explain the causal links in real-life situations; it is a way to investlgate an emplrical subject by following preset procedures or questions; and, it allows the inguiry to 
retain meaningful characteristics from actual events ( $Y$ in, 1984, p.25 \& 14). Case studies, then, can be the beginning for the study of new areas in the organizational, social, polltical, and Indlvidual occurrences (Simon, 1969, p.52; YIn, 1984, p.14). Most case studies exhibit the following character lstics:

...more sulted to expansionlst than reductionist pursults...prol iferates rather than narrows...attends to the ldiosyncrat lc more than to the pervasive...adds to existing exper lence and humanistic understanding (Stake, 1983, p.284).

\section{IIMITATIONS OF THE CASE STUDY METHOD}

Stake (1978) belleves that case studles are useful in humanlstic understandlng because they are not only interesting to read but get down to the baslcs in the study of human affairs. He acknowledges, though, that case studles are in some instances not sultable for generalizations (p.7). This is the most common criticism of the case study approach to research-- generallzability. Borg and Gall (1983) support this view when they state that It is risky to draw any general conclusions from a single case study. They acknowledge that there is no way of the researcher knowing how typical the case really is (p.488) YIn (1984) acknowledges that al though the question of generalizability is not a simple one to answer he suggests that: 
...case studies, like experiments, are generallzable to theoretical propositions and not to populations or unlverses. In this sense, the case study, like the experiment, does not represent a "sample", and the investigator's goal is to expand and generalize theorles (analytic generalization) and not enumerate frequencies (statistical generalization) (p.21).

Other limitations that have been volced concerning the use of the case study method. One of these is that a case study takes too long and results in a research report that, because of 1 ts size, becomes almost unreadable. Another critlcism is the lack of rigor in the research because of sloppy and blased methodology on the Investigators part (YIn, 1984, p.21).

However, the disadvantages of the case study method may become secondary to the advantage of Increased understanding:

When the aims are understanding, extension of experlence, and increase in conviction in that which is known, the disadvantage (of the case study) disappears...the knowledge (that is gathered) is a form of...naturalistic generalization, arrived at by recognizing the similarities of objects and issues in and out of context and by sensing the natural covariations of happenings. To generallze thls way is to be both intultive and empirical... (Stake, 1983, p. 281-2822 


\section{LIMITATIONS OF THE STUDY}

(1) It is assumed that the organizational theories of organized anarchy and loose coupling, accurately represent the university-higher education organlzation.

(2) The size of the student body of the university selected will not be limited to any particular size. Therefore the size of the selected student population might not reflect an average slze of an instltution of higher learning.

(3) In order to eliminate the increased stress on performance, professional $\mathrm{lsm}$, and the generation of funds that can be found in most NCAA DIvision I and II programs and that therefore could possibly skew the results of this research, the study involves one university-higher education organization representing an NCAA Division II Institution. Therefore, thls will eliminate from the study a representative sample of an NCAA Division I and II institution.

\section{THE SAMPLE}

The University of Callfornia, San Diego (UCSD) Athletic Department was selected for this study. This university was selected because it was an accessible Division II institution and, because of its collegiate, university type atmosphere, would least likely exhlbit high performance characterlstics and more likely exhlbit characteristics inherent in organized anarchies and loosely coupled systems. 
The other criterla used for the selection of this institution were:

(1) A four-year college or university that has an intercollegiate athletic program associated with the National Collegiate Athletlc Assoclation.

(2) A Division III institution as defined by the National Collegiate Athletic Assoclation

(3) An athletic department that must be a separate department within the organizational structure of the university.

(4) The athletlc director must have headed the athletlc department of the institution for at least two years.

Criterla used to decide which teams, coaches, and athletes were selected to be interviewed for the study are:

(1) Five men's teams and five women's teams were selected using a stratifled random sampling method.

(2) Only teams with a head coach that have been at UCSD for at least two years could be used as part of the sample.

(3) Three athletes from each team were selected using a random sampling method.

A total of forty-one subjects were selected to be Intervlewed: the Athletic Director, five head coaches of men's teams, five head coaches of women's teams, and thirty athletes from these respective teams. 
DEVELOPMENT OF THE INSTRUMENT

A guide, designed by the researcher, was used during the interview portion of this research. It consisted of 34 questlons. Each of these questions were designed to reflect a speciflc criterla and or characterlistlc of a high performance system as defined by Vaill. These questions were used to investigate the athletic department at the University of California, San Diego to see if in fact it could be defined as a high performance system. isee Appendix A for a copy of the questions in the intervlew guide.)

\section{INTERVIEWS}

Data were gathered through indlvidual intervlews with the researcher serving as the Intervlewer. Each interview was semi-structured and used the focused Interview approach. The purpose of using the focused interview technique was: ... In a focused interview the limits of relevance are largely self-defined for the intervlewee by prior analysis of the situation in which subjects have been involved... Equipped in advance with an analysis of the sltuation the interviewer can readily distinguish the objective facts of the case from the subjective definitions of the situation... developing an interview ouldee setting forth the major areas of inquiry and the hypotheses whlch provide criterla of relevance for the data to be obtalned in the interview (Merton, Fiske, \& Kendall, 1956, p.3-4). 
The interviews were scheduled for a two-hour perlod for rach of the Individual coaches and the Athletic Director and a one-hour perlod for each of the individual athletes. Each of the interviews gathered such descriptive data on the interviewee as sex, length of time with the UCSD, and length of time involved with athletics at the UCSD. The interviews focused on the subjects' percelved goals and purposes of the institution's athletic department and areas involved in the criterla and characteristics of hlgh-performing systems. As suggested, by Merton, Flske, and Kendall (1956) the questions that provided a guide to the interview related to eliciting significant types of responses concerning the criterla and characterlatics of hlgh-performing systems (p.43). The subjects were encouraged to relate their perceptions about the performance of the athletic department and or their individual teams and athletic directors performance.

During the interviews tape recordings were made. It was decided to use tape recordings because they "provide a more accurate rendition of any interview than any other method" (Yin, 1984, p.85). Also, as Torbert (1981) states:

such records...(as) tape-recordings... allow partlcipants or other interested persons to find post hoc clues about what else besides the defined variables and the presupposed explanations was going on in a given situation (p.149).

After the intervlews were completed, the interviewer transcribed these interviews from the tapes onto a data 
sheet. (See Appendix B for a copy of the data sheet.) As Borg and Gall state," the use of recordlngs...permits both qual ltatlve and quantltative data" (1983, p.491). In order, therefore, to verlfy the accuracy of the transcrlptions that the researcher recorded from these tapes, every fifth tape was reviewed by an Independent party. Dr. Barbara Blourock, who has been Dean of Counselling at Southwestern College in Chula Vista, California, and expert in the intervlew process, provided this needed task in order to insure both acceptable rellability and Internal validity for the study.

DATA GATHERING

Additional printed materlal was gathered to supplement the information collected during the interview process. See Append $\mathrm{X} C$ and $D$ for a copy of the reglonal and national Championships that the UCSD's athletic teams participated in or won durling the school years 1984-85 (Before this study was conducted.) and 1985-86 (During the time this study was being completed). Appendix E contains a copy of an signiflcant article from the University's newspaper.

\section{DATA ANALYSIS}

Most case studies are based on the premlse that a case can be located that is typlcal of many other cases, that 13 , the case is viewed as an example of a class of events or a group of Individuals (Borg \& Gall, 1983, p. 488-489). 
The data for thls study contained the reactions and perceptions of the team members, coaches, and the Athletic Director concerning the teams and the athletic department and their relationship to the higher-education organization, the University of Callfornla, San Diego.

The following procedure was followed in the data analysis:

(1) Each of the taped interviews was transcribed onto specially developed record sheets. (See Appendix B for copy of the data sheet.)

(2) Each item was analyzed as to whether or not the response elicited from the various subjects did in fact reflect one of the criteria or characteristics of a high performance system.

(3) Each question was further analyzed to find the most significant words in the response in relationship to the question asked. These slgnificant words were recorded on the Response Analysis Form. (See Appendlx F for copy of this form. )

(4) Each of these slgniflcant word responses was analyzed to see whether or not the response was in agreement with the response given by the Athletic Director. A 70 percent level of agreement was established. It was decided that a 60 percent level of agreement was too low whlle an 80 percent or hlgher level of agreement was too unreallstic. Each question had to achieve a 70 percent agreement between the Athletic Director's response and the responses of the 
forty coaches and athletes in order for the response to be used in the analysis of data.

A 70 percentage level of agreement was established in order to reflect the nature of leadership in a high performance system. As Valll (1984) states, "leadership in HPS is strong and clear" (p.86). In other words, there is a strong level of congruence between what the leader feels concerning what direction the organization is taking or what the organization is trying to accomplish and the understandling the people in the organization have about the direction and purpose of the organization. Thus, if the leadershlp is strong and clear, as Vaill suggests, there should be a hlgh percentage of agreement between the response the Athletic Director glves concerning the athletic department and what the coaches and athletes respond to each of the interview questions. Therefore, this researcher declded that a percentage based on the level of agreement between the what the Athletic Director stated and what the coaches and athletes responded would better reflect the strong and clear leadership style that must occur within a high performance system.

(5) A Likert scale was developed for each question that recelved a 70 percent agreement level between the Athletic Director and the coaches and athletes. Each scale ranged the responses from those that showed the most agreement to the response that had the lowest level of congruence between the Athletic Director and the coaches and athletes. 
(6) A bar graph was developed using the Ilkert scale in order to make the analysis and explanation of the responses to the selected questions clearer. 


\section{CHAPTER IV \\ ANALYSIS OF DATA}

The primary purpose of this case study was to look beyond the descriptive terms of organized anarchy and loose coupling and find a possible explanation of how excellent performance can occur in an higher education organization usually described as anarchic and loosely coupled. The case study focused on the athletic department at the University of Callfornia, San Diego which year after year has produced excellence desplte being part of such a higher education organlzation.

The secondary purpose was to demonstrate emplrically that an example of Vaill's high performance system exists within the university-higher education organization. It is hoped that by finding an empirical example of this model within the university its organizational structure will be given greater clarity of understanding.

Finding that a high performance system does in fact exist within the higher education organization, this study w1ll assist leaders within colleges and universities to have a greater understanding of the organizational structure of their own institutions. Basic to leadership is the understanding that there are different parts of the same 104 
organlzation using different goals and purposes from those espoused by the institution as a whole. By acknowledging that these different goals and purposes could result in at least two different organlzational structures functioning within one institution, leaders will be more successful in their tasks because they will approach different parts of their organizations in different ways.

Data was obtalned by interviewing various members of the UCSD athletic department using an interview gulde designed by the researcher. The athletic director, ten coaches, and thirty athletes were interviewed $(N=41)$. The interview guide was used in all 41 interviews.

All responses to the questlons were analyzed to see which ones achleved a $70 \%$ agreement between the athletic director and the coaches and their athletes. Responses that did not achieve this level of agreement were not used in this analysis of data. Thus, the data presented in this section represent only those responses that achieved at least a $70 \%$ agreement between the Athletic Director and her coaches and athletes.

Graphs were developed to visually illustrate the congruence of the data. Each graph shows the exact responses given by the subjects, the total number of responses that agreed with the Athletic Director's response, and the percent of agreement achleved between the coaches' and athletes' responses and the response given by the Athletic Director. 
RESEARCH QUESTION 1: Can an athletic department be found, within the university-hlgher education organlzation, that can be characterlzed as a high performance system?

RESEARCH QUESTION 2: If so, what makes it a high performance system?

The following interview questions are directly related to the criterla and character lstlcs that Valll has attributed to high performance systems.

Interview Question 1: How would you compare the performance of your athletic department (or team) with other Division III departments (or teams)? This question is related to Vaill's (1984) first criterion for high performance systems: They are performing excellently agalnst a known external standard (p.86).

The Athletic Director agreed that the UCSD program contalned some of the most competitive Division III teams in the country as evidenced by the number of champlonships the teams had either won or participated in the previous year. (Appendix F has the Response Analysis Form for this question that gives the significant word response for each interviewee.) Thirty-five of the forty people interviewed, or 87.5 percent, agreed with her that UCSD had one of the best Division III programs.

Graph 1 shows how congruent the responses actually were. The responses ranged from considering UCSD to be one of the best, if not the best Division III programs in the country, to the athletic program being deslgnated as "good". 
GRAPH 1:

Interview Question \#1: How would you compare the performance of your athletic department (or team) with other Division I I departments (or teams)?

\section{NUMBER OF RESPONSES}
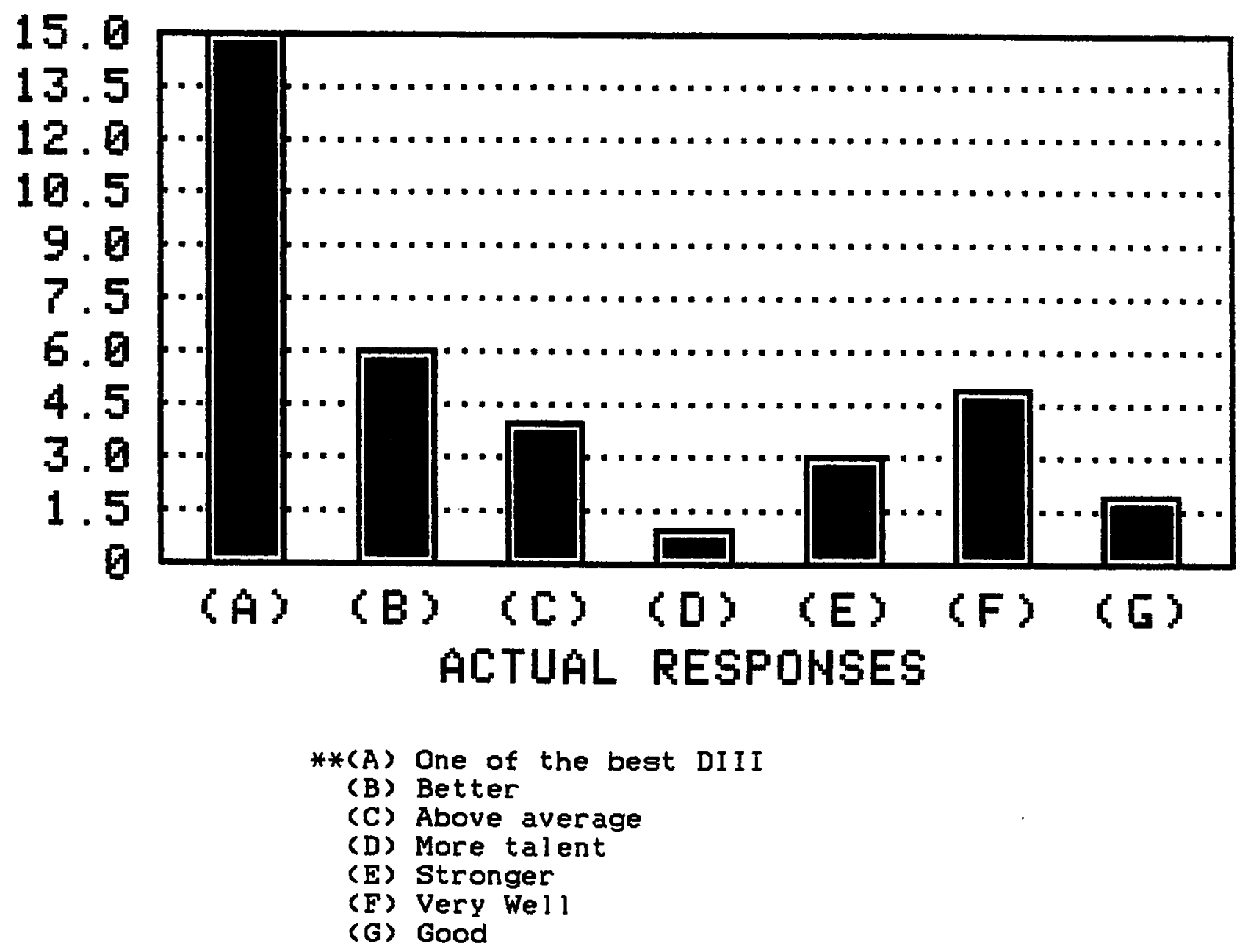
Fifteen ( 42 percent) of the subjects, including the Athletic Director agreed that their performance made them one of the best Division III programs or teams in the nation. Six responses ( 17 percent) thought that UCSD was "better" than other Division III programs or teams. Four (11 percent) of the subjects stated that they were "above average" to other Division III programs or teams. One of those interviewed (2 percent) thought that they "had more talent". Three subjects ( 8 percent) characterized UCSD as being "stronger". Five ( 14 percent) thought UCSD "did well" against Division II competition while two ( 5 percent) stated the program was "good" .

The results of question 1 show that not only was there 87.5 percent agreement between the Athletic Director and the forty coaches and athletes interviewed but that almost one-half ( 42 percent) used her exact words and or meaning and placed UCSD as performing successfully against the known standard of Division III competition. It seems, then, that all those interviewed agree with the Athletic Director that the UCSD athletic program is performing excellently against a known external standard (other Division III teams) which is one of Valll's criteria for HPS. Visually this agreement is shown by the size of the bar $A$ on the extreme left of graph 1 .

Intervlew Question $3 A$ and B: How would you compare the athletic department (or your team) now to where it was when you first arrived at UCSD? Do you feel that there has been 
a leveling off, or a decrease in development? This question is related to Vaill's (1984) third criterion for high performance systems: They are performing excellently relative to where they were at some earlier point in time $(p .86)$.

The Athletic Director stated that when she first arrived at UCSD the program was not only not competitive at the national level but had, In fact, a sports club atmosphere. She state unequlvocally that there has been an improvement. (Appendix F has the Response Analysis Form for this question that gives the slgnlflcant word response for each interviewee.) Thirty-nine of the forty people Intervlewed, or 97.5 percent, agreed with her that there had been an overall improvement in the athletic program since they became part of the department.

Graph 2 shows how congruent the responses actually were. The responses ranged from estimating that there had been a 100 percent improvement to stating that there was a blt of an increase. Two ( 5.5 percent) of the subjects agreed that there has been a "100 percent" Improvement in the program since they flrst became a part of the UCSD athletlc program. Twelve responses ( 30 percent) thought that there had been a "definite improvement". Twenty <50 percent) of the subjects, including the Athletic Director, thought that there had been an "Improvement". Three ( 8 percent) of the subjects stated that there was "an increase in development". Two ( 5.5 percent) of those inteviewed thought that there had been only a "slight improvement" 
GRAPH 2:

Interview Question \#3A \& B: How would you compare the athletic department (or your team) now to where it was when you first arrlved at UCSD? Do you feel that there has been a leveling off, or a decrease in development?

\section{NUMBER OF RESPONSES}

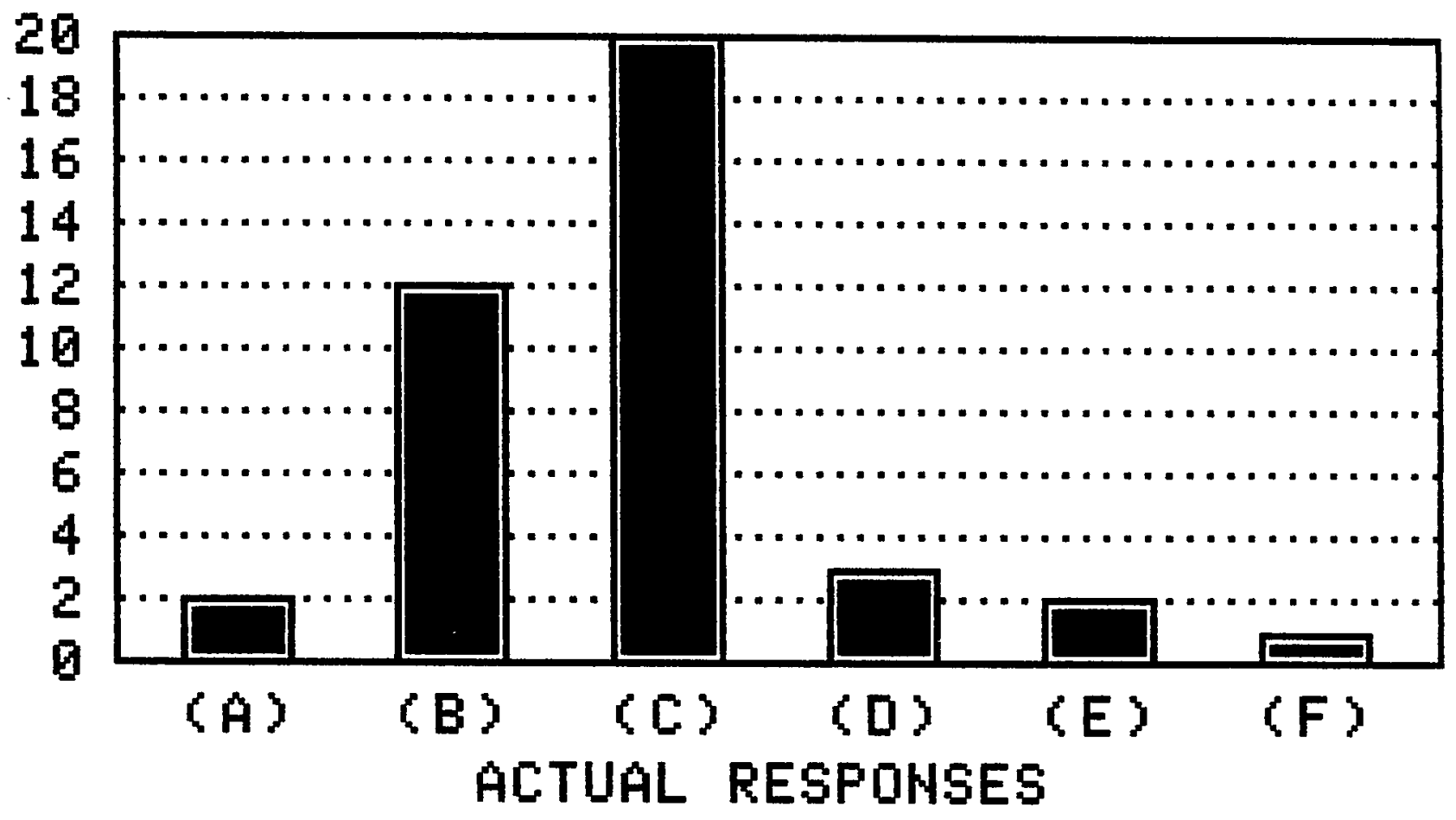

**(A) 100 percent improvement

(B) Definite improvement

(C) Improvement

(D) Increase

(E) Slight improvement

(F) Bit of increase

**Athletic Director's response

Percent of agreement $=.975$

Total number of responses in agreement $=39$ of 40 
whlle one ( 1 percent) stated there had been a "bit of an increase".

The results of question $3 A$ show that not only was there an 97.5 percent agreement between the Athletic Director and the forty coaches and athletes interviewed but half <50 percent) used her exact words in stating that there had been an improvement. In fact, only one of the subjects interviewed thought that there had not been an improvement. This athlete attributed the lack of improvement in his team to the number of injurles sustained during the present season. In reviewing the 97.5 percent agreement level, it can be stated that the UCSD's athletlc program is performing excellently relatlve to where they were at some earller point in time. Visually, this agreement becomes quite apparent by the size of the bar $A$ and $B$ on the left of the graph.

Interview Question 4: Has the athletle department for your team) ever been judged by others to be better than other Division III departments (or teams)? This question is related to Vall's (1984) fourth criterion for high performance systems: They are judged qual itatively by informed observers to be doing substantially better than other comparable systems $(p, 86)$.

The Athletic Director agreed that UCSD had some of the top Division III teams in the country as verlfied by an NCAA report that stated that UCSD was second in the nation in participation in national champlonshlps. She also stated, 
that on a more casual basis, many people from other inst Itutions have often commented to her about the success of the UCSD program. (Appendix F has the Response Analysis Form for this question that glves the significant word response for each interviewee.) Thirty-four of the forty people interviewed, or 85.0 percent, agreed with her that in their opinion UCSD had a "substantlally better athletic program" than other Division III athletic programs.

Graph 3 shows how congruent the responses actually were. The responses ranged from considering the teams from UCSD as being top in the country to that the UCSD athletic program should be in another NCAA division. Eleven of the subjects ( 31 percent) agreed that, "yes", they have been Judged better than other Division III teams. Sixteen responses ( 46 percent), including the Athletic Director, thought that UCSD's athletic program contained elther someof the "top Division II teams in the country" or that their partlcular "team was one of the top teams in the country". One subject ( 3 percent) stated that the program was "much better". Two subjects ( 6 per cent) interviewed thought that UCSD was "very strong". One subject ( 3 percent) characterized UCSD as being "really good". Another ( 3 percent) thought that the "proof comes with success" while three ( 8 percent) stated that UCSD should be in "another. higher, NCAA division".

The results of question 4 show that not only was there an 85.0 percent of agreement between the Athletic Director and the forty coaches and athletes interviewed but that 
Interview Question \#4: Has the athletic department (or your team) ever been judged by others to be better than other Division III departments (or teams)?

\section{NUMBER OF RESPONSES}

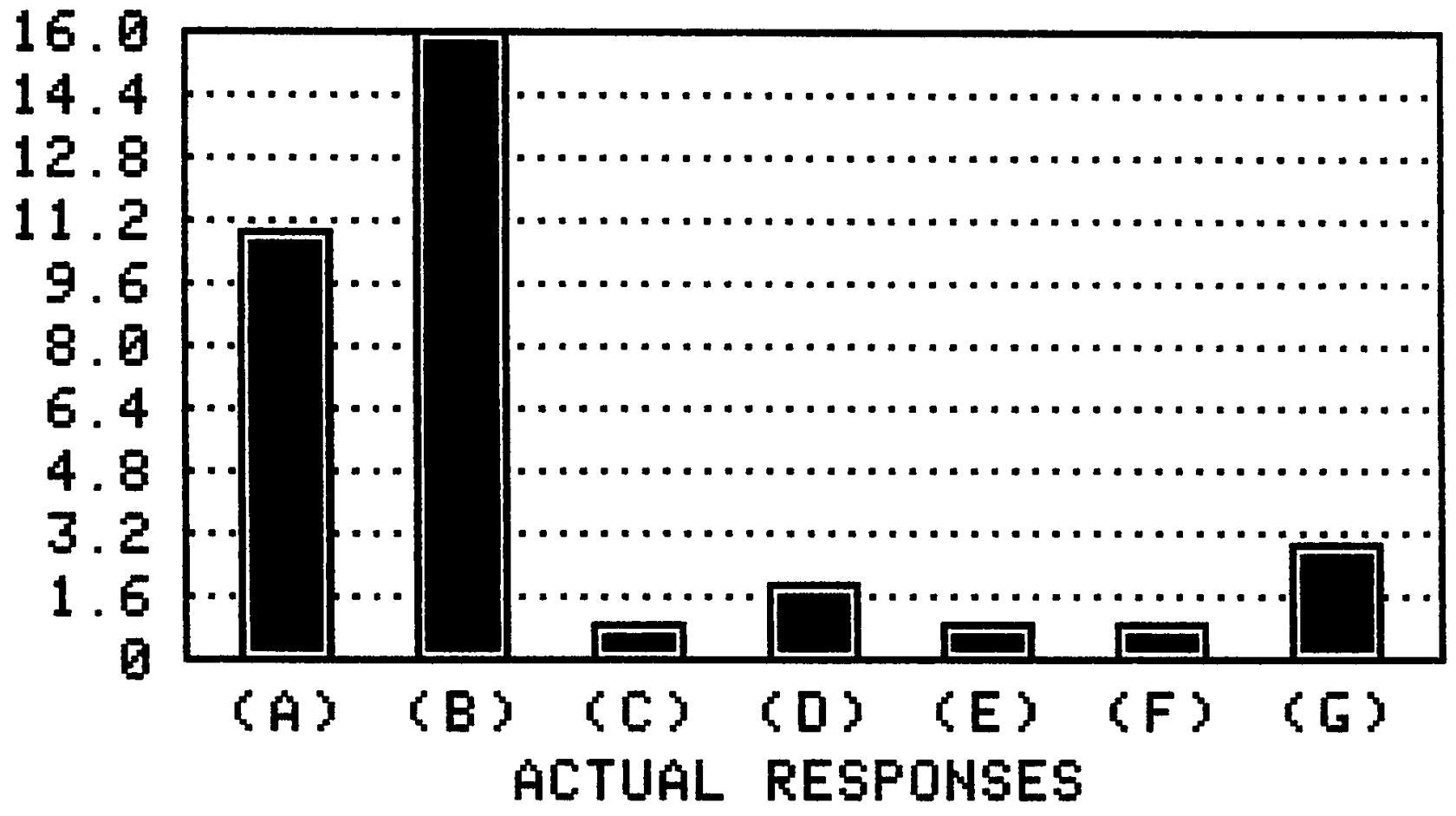

(A) Yes

**(B) One of top teams in country

(C) Much better

(D) Very strong

(E) Really good

(F) Proof comes with success

(G) UCSD should be another division

**Athletic Director's Response

Percent of Agreement $=.850$

Total number of responses in agreement $=34$ of 40 
almost one-half ( 46 percent) elther used her exact words and or meaning and placed UCSD in the position of being one of the top Division III teams in the country. Judged by informed observers both outside and inside the UCSD athletic department the program can be characterized as doing substantially better than other Division III programs. Visually, agreement is quite evident by the size of bars $A$ and $B$ in relation to others in the graph.

Interview Questlon 5A \& B: What is the budget for the athletic department (or your team)? Based on your knowledge do you feel that it is above average, average, or below average in relationship to other Division II athletic departments (or teams)?

Interview Question 7: How would you compare the athletic facilities at UCSD with ather Division III institutions: above average, average, or below average? These questions are related to Valll's (1984) flfth criterion for high performance systems: They are doing whatever they do with significantly fewer resources than it is assumed are needed to do what they do $(p .86)$.

The Athletic Director stated, when answering questions $5 A$ and $B$, that it is her understanding based on conversations with other athletic directors that other Division III athletic programs are better funded than UCSD is for theirs. (Appendlx $F$ has the Response Analysis Form for this question that glves the significant word response for each interviewee.) Twenty-six of the forty people 
Interviewed, or 65.0 percent, held similar views that UCSD was "not funded as well" as other Division III institutions. Although the answers to this question did not recelve the 70 percent overall agreement they did, however, receive a 70 percent agreement among the coaches. If in fact, you throw out the response of the coach that stated, "I can't remember", there was an 80 percent agreement between the Athletic Director and the coaches. Because of the administrative nature of their job, the coaches not the athletes are usually directly involved in the formal budget process. The athletes were making their judgement based on what they were using seemingly unaware of where the equipment came from. As indlcated by many of the interviewees, many of the teams raised money in order to provlde the necessary equipment for their teams thereby influencing what equipment was avallable for team use. Thus, it seems, in response to this question, many of the athletes could not separate the university provided equipment and the equipment bought with outside funds. The coaches, however, were fully aware of the difference because of the effort it took on their part to get the additional funds to purchase this needed equipment. Therefore, the researcher declded to include this response because of the 70 percent agreement between the coaches and the Athletic Director.

Graph 4 shows how congruent the responses were for questions $5 A$ and $B$. The responses ranged from "others are funded better" to "outside support comes from companles." 
Graph 4:

Interview Question \#5A \& B: What is the budget for the athletic department (or your team)? Based on your knowledge do you feel that it's above average, average, or below average in relationship to other Division II athletic departments (or teams)?

\section{NUMBER OF RESPONSES}

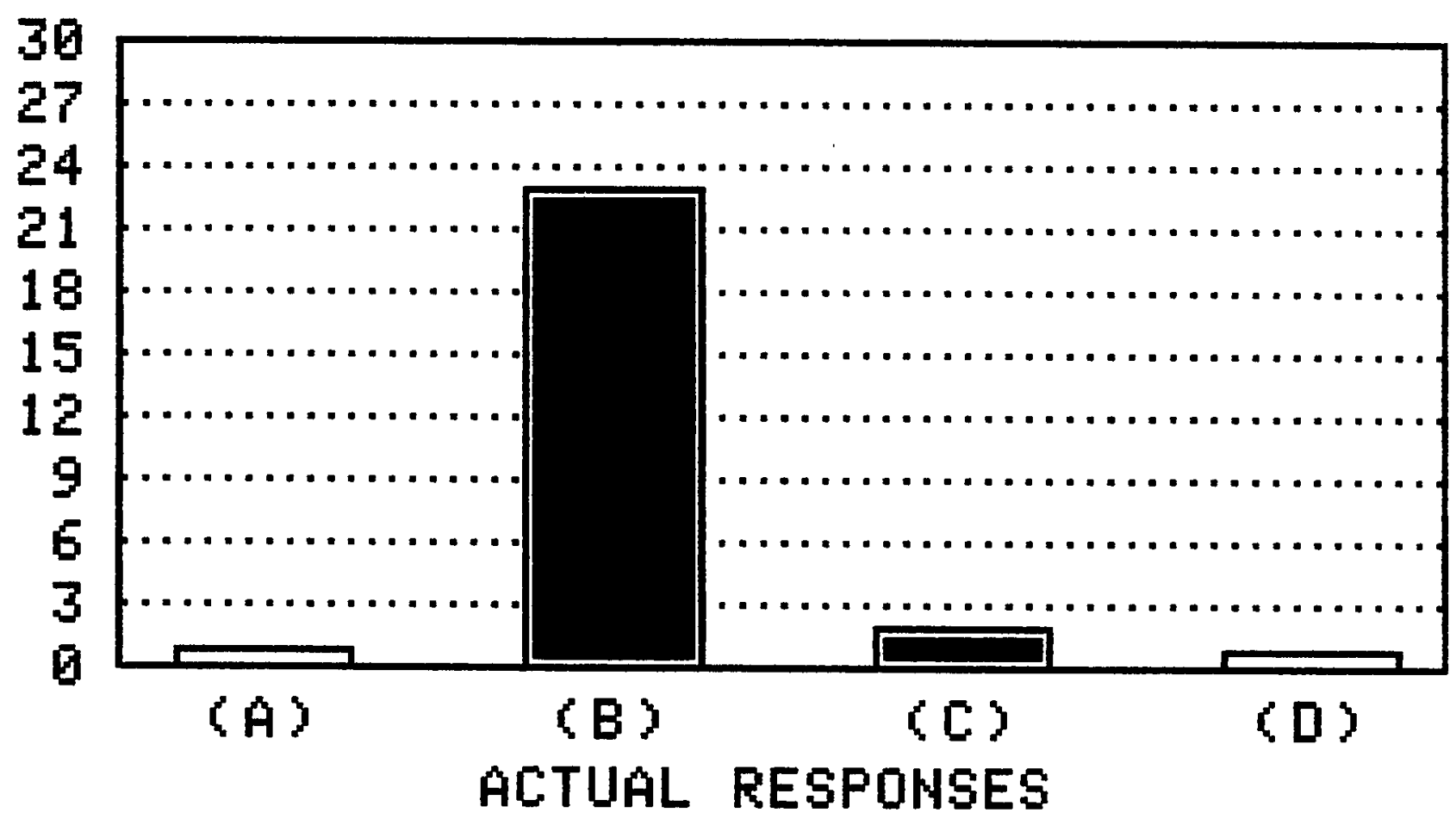

**(A) Others funded better

(B) Below average

(C) Really low

(D) Outside support, companies

** Athletic Director's response

Percent of agreement $=.650$

Total number of responses in agreement $=26$ of 40

Percent of agreement for coaches $=.700$ 
The Athletic Director (4 percent) stated that other Division IIIs were "funded better". Twenty-three responses ( 85 percent) thought that UCSD was funded "below average" in comparison to other Division III institutions. Two (7 percent) of the subjects stated that thelr budget was really low" . One of those interviewed ( 4 percent) stated that they "recelved their funding from outside companies".

The results of question $5 A$ and $5 B$ show that the UCSD Athletic Director and her coaches agree that they are being funded at a level that is below average for Division III instltutions and therefore spending less money than their competition. Visually, this agreement becomes quite evident by the slze of bar B that represents the below average response in graph 4 .

In response to question 7 , the Athletic Director stated that some of UCSD's facllities are substandard when compared to other Division III institutions and overall could be characterized as "average to below average". (Appendix F has the Response Analysis Form for thls questlon that gives the significant word response for each intervlewee.) Thirty of the forty people interviewed, or 75.0 percent, agreed with her that UCSD had facilities that were either below average or average.

Graph 5 shows how congruent the responses actually were. The responses ranged from consldering UCSD having "extremely below average" facllities to their facllities belng "average". Two of the subjects $(7$ percent) agreed that their facilities were "extremely below average". 


\section{GRAPH 5:}

Interview Question \#7: How would you compare the athletic facilities at UCSD with other Division III institutions: above average, average, or below average?

\section{NUMBER OF RESPONSES}

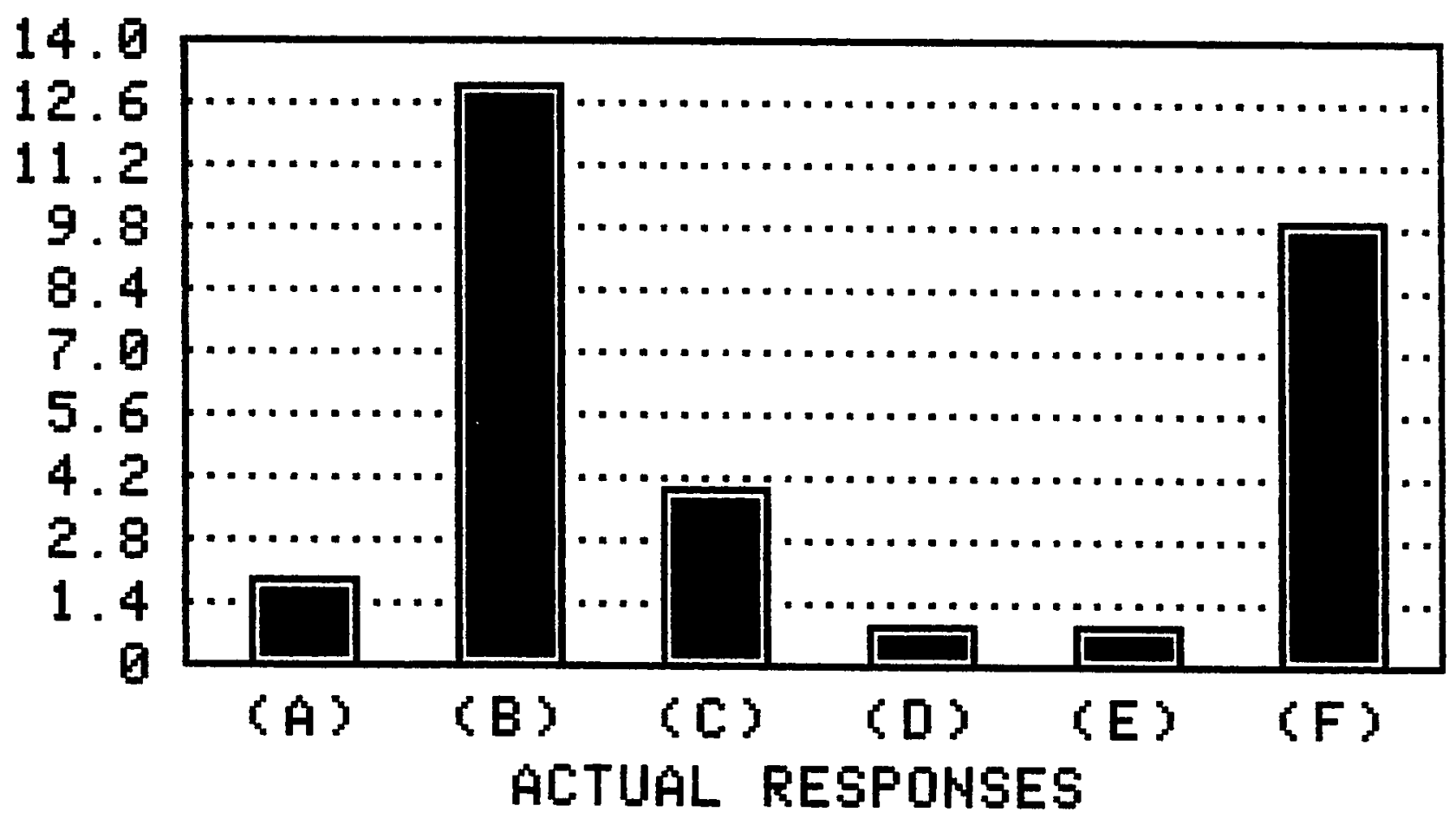

(A) Extremely below average

(B) Below average

(C) No adequate facilities

**(D) Average to below average

(E) Far below average

(F) Average

**Athletic Director's response

Percent of agreement $=.750$

Total number of responses in agreement $=30$ of 40 
Thirteen responses ( 42 percent) thought that UCSD was "below average". Four ( 13 percent) of the subjects stated that there were "no adequate facilities" for their teams. The Athletic Director ( 3 percent) stated that the facilities were "average to below average" when compared to other Divison III institutions. Another subject interviewed ( 3 percent) thought the facllities were "below par". Ten of those interviewed ( 32 percent) stated that the facilitles were "average".

The results of question 7 shows that although there was a 75.0 percent agreement between the Athletic Director and the forty coaches and athletes interviewed, the answers fell into groups of responses: below average or average. Visually this groupling of responses becomes quite evident by the slze of bars $B$ and $F$ in graph 5. As stated previously, 32 percent characterjzed the facilities as belng average. However, 68 percent of those who gave congruent responses, thought the facilities were below average.

Interview Question 10c: Would you say the athletic department better reflects its own culture rather than the unlversity as a whole? This question is related to Valli's (1984) seventh criterlon for high performance systems: They are percelved to fulfill at a high level the ldeas of the culture within which they exist (p.86).

The Athletic Director agreed that UCSD program reflected its own culture. SAppendix $F$ has the Response Analysis Form for this question that gives the significant 
word response for each interviewee.) Thlrty-three of the forty people interviewed, or 82.5 percent, also agreed with her that the UCSD athletic department reflected its own cul ture.

Graph 6 shows how congruent the responses actually were. The responses ranged from the department "definitely" reflecting its own culture to "I guess it does". Two of the subjects ( 6 percent) agreed that it "definitely did". Elghteen responses ( 53 percent), including the Athletic Director, thought that, "yes", the department reflected its own culture. Seven (21 percent) of the subjects stated that they "thought it did". Two of those interviewed ( 6 percent) characterized the UCSD athletic department as being "dlfferent". Three ( 9 percent) stated that it "probably did". One ( 2.5 percent) thought that "In a way" UCSD reflected its own culture while another subject $<2.5$ percent) "guessed it dld".

The results of question $10 \mathrm{C}$ show that not only was there an 82.5 percent agreement between the Athletic Director and the forty coaches and athletes interviewed but that over one-half ( 53 percent) used the Athletic Director's exact words in agreeing that UCSD's athletic department better reflects it own culture. The athletic department is being viewed as having their its own culture by a large percentage of people within the department thereby indicating that it fulfills a high level of Ideas within the culture. Visually this is seen in graph 6 . 
GRAPH 6:

Interview Question \#10C: Would you say the athletic department better reflects its own culture rather than the university as a whole?

\section{NUMBER OF RESPONSES}
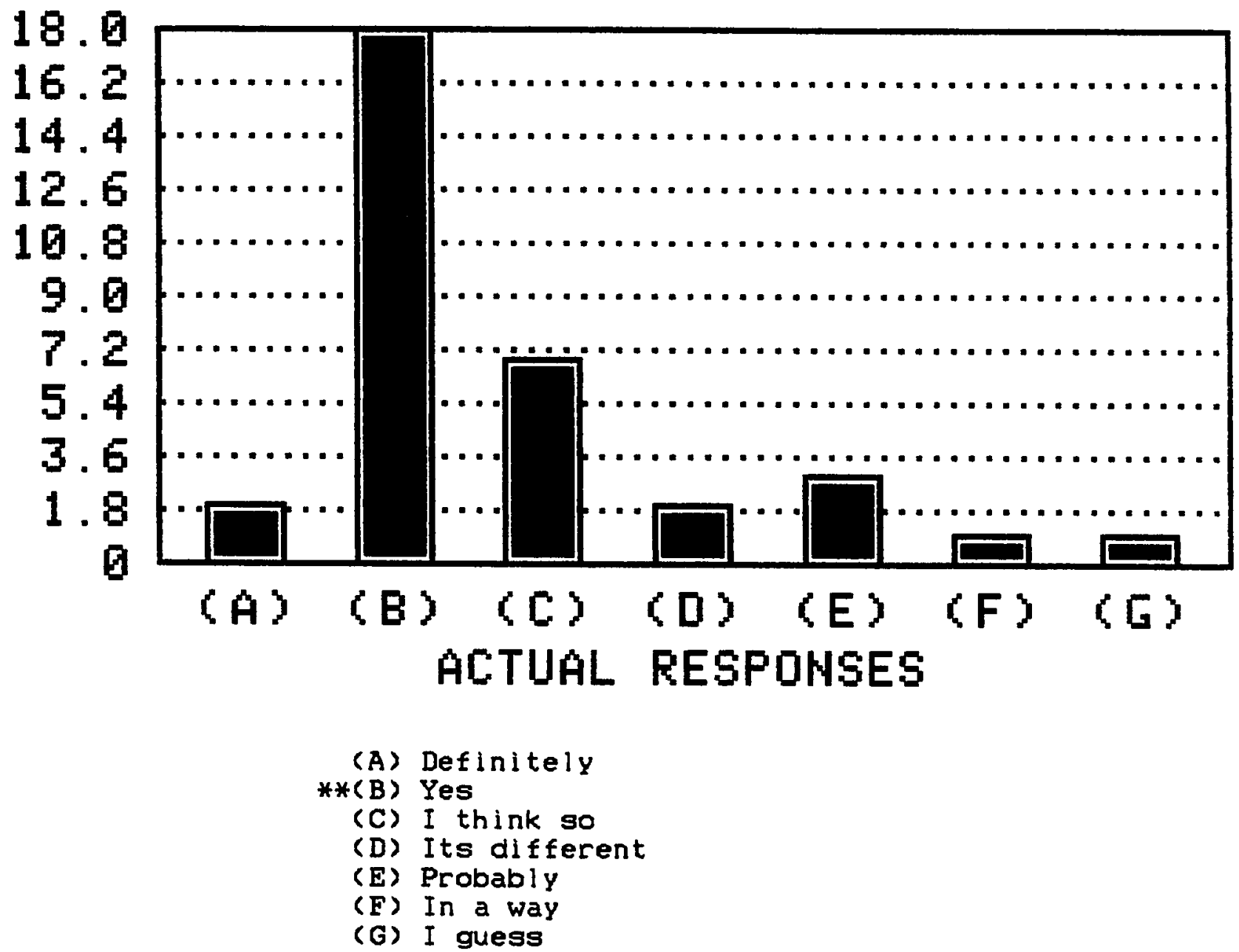
Interview Question 11A: What would you say are the broad purposes of the athletic department of UCSD? This question is related to Valll's (1984) flrst characterlstic for high performance systems: HPSs are clear on their broad purposes and on nearer term objectives for fulfllling these purposes $(p .86)$.

The Athletic Director agreed that the UCSD athletic department's purpose is to provide positive opportunities and generate spirit within the university. (Appendix F has the Response Analysis Form for this question that gives the signiflcant word response for each intervlewee.) Thirty of the forty people interviewed, or 75.0 percent, agreed that the purpose of the program was to "provide opportunity", In some form, and "to get people involved" in order to increase spirit.

Graph 7 shows how congruent the responses actually were. The responses ranged from suggesting that the athletic department "provides another way to excell" to it provides for mass "participation". Four of the subjects ( 13 percent) agreed that the UCSD athletlc department "provides another way to excell" within a university that prides itself on excellence. Five responses ( 16 percent), Including that of the Athletic Director, indicated that the department provided "positive opportunities and generated spirit". Elght (26 percent) of the subjects stated that the purpose was to "provide an opportunity to compete". Five subjects ( 16 percent) thought it was to "promote sports". Five of those interviewed ( 16 percent) thought that the 
GRAPH \#7:

Interview Question \#11A: What would you say are the broad purposes of the athletic department of UCSD?

\section{NUMBER OF RESPONSES}

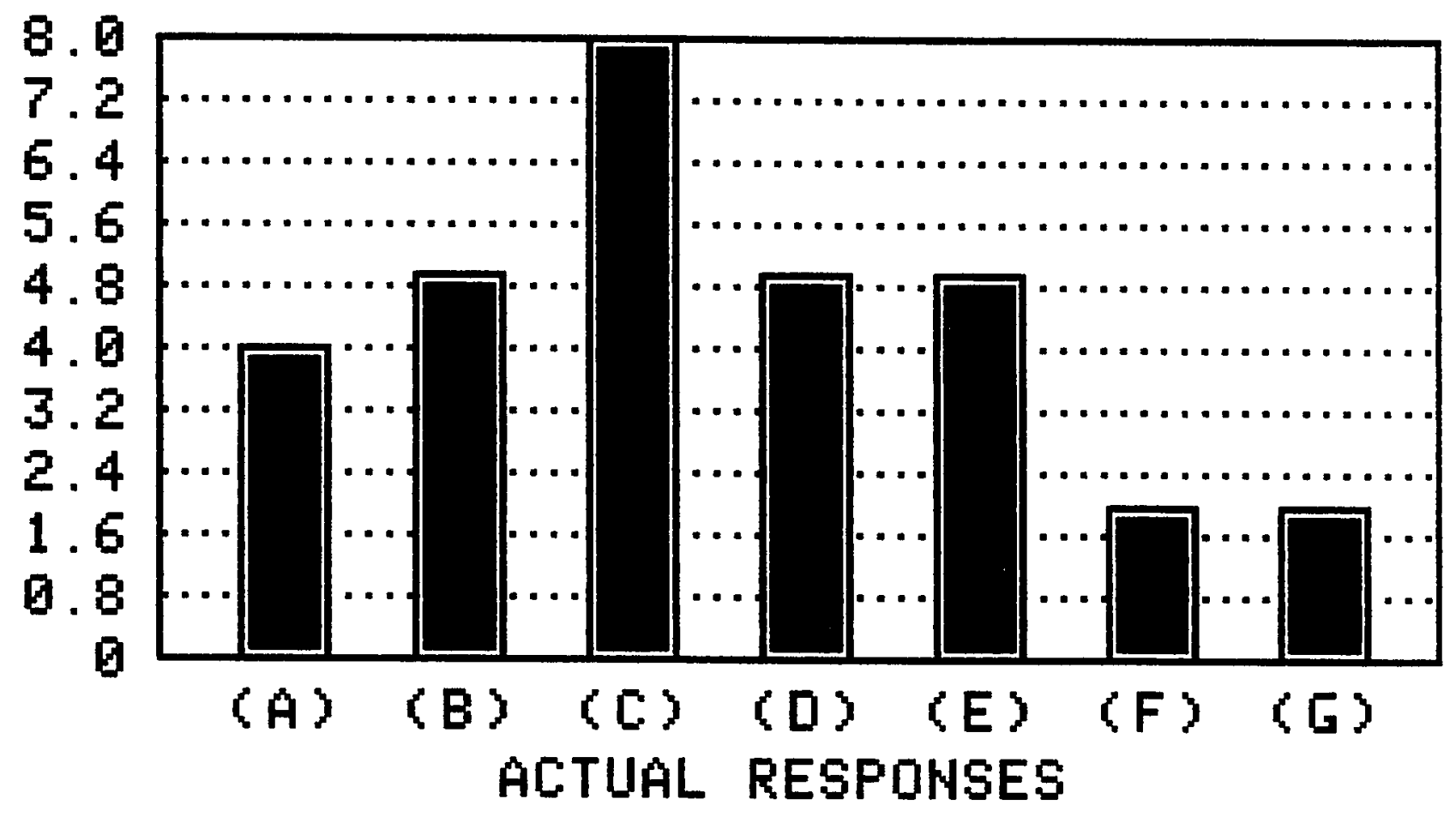

(A) Provide another way to excell

**(B) Positive opportunities \& generate spirit

(C) Opportunity to compete

(D) Promote sports

(E) Offering something outside of academics

(F) To get people involved

(G) Provide for mass participation

**Athletic Director's response

Percent of agreement $=.750$

Total number of responses in agreement $=30$ of 40 
athletic program could offer "something outslde of academics" to the student/athletes. Two subjects $<6.5$ percent) stated the purpose is to "get people involved" while two others ( 6.5 percent) thought the department was there to "provide for mass participation" of student/athletes.

The results of question $11 \mathrm{~A}$ show that there was an 75.0 percent of agreement between the Athletic Director and the forty coaches and athletes interviewed that there were two main purposes for the athletlc department. The number of responses did not fall equally between the two group of responses. Of those who answered in agreement, twenty-two or 71 percent stated that the athletic department provided "opportunitles to compete" while nine responses or 29 percent thought that the main purpose was "to promote splrit". It could be stated that the people who make up the UCSD's athletlc department are clear about the two main purposes of the athletic department. Thelr opinions, however, were varled as to what objectives were necessary in order to achleve these purposes. (See the Appendix $F$ for the Response Analysis Form for question 11B: What objectives do you see as important to fulfllling these purposes?) Six of the forty people interviewed, or 15.0 percent, agreed with the Athletic Director that the objectlves were to "provide a quality experience" and to "generate and supply Information". The other 85.0 percent had differing opinlons. Although these dlffering opinions occurred in the stated objectives by each subject, when it came to whether 
or not the coaches were commltted to these objectives the opinions were not as varled. In the responses given to question $12 \mathrm{~B}$ that is discussed in the next section, it is agreed by 75.5 percent of those intervlewed that the coaches were committed to the purposes and objectives as stated by the interviewees during the interview. Therefore, although there was not consensus among the subjects as to what were the exact objectives necessary to fulf 111 the agreed upon purposes, it was clear to thirty-one of those interviewed that they were all committed to the goals and purposes of the athletic department.

Interview Question 6A: As a department is there (or As a ceach is there or Does vour ceach make) a concentrated effort to recruit talented athletes?

Interview Question 6B: Based on your knowledge do you feel that the talent represented by the student/athletes in the athletic department (or on your team) is above average, average, or below average in relationship to other Division I I departments (or teams).

Interview Question 12A: Do you feel that the UCSD athletle team coaches (or you as a coach or your coach) give extra effort beyond what is expected of them sor you or him/hers?

Interview Question 12B: How committed do you feel the coaches are (or you are or your coach is) to your previously stated broad purposes and objectives of the athletic department? 
Interview Question 12C: How would you descr ibe the motivation of the coaches? (coaches only: How motlvated are you?) These questions are all related to 'Valll's (1984) second characterlstic for high performance systems: Commltment to these purposes is never perfunctory al though it is often expressed laconically. Motivation is usually concelved as high (p.86).

The Athletic Director said, in responding to Question $6 A$, that generally, "yes, the UCSD coaches make a concentratea effort to recrult talented athletes". CAppendix $F$ has the Response Analysis Form for this question that glves the signiflcant word response for each interviewee.) Thirty-two of the forty people interviewed, or 80.0 percent, agreed that there was a definlte recruiting effort made.

Graph 8 shows how congruent the responses actually were. The responses ranged from reporting that there was a "very concentrated effort" by some of the coaches to some of the coaches were "semi-active" in the recruiting process. Two of the subjects ( 6 percent) agreed that there was a "very concentrated effort" to recrult. Two responses ( 6 percent) thought that the coaches "definitely did recruit". Twenty-four ( 73 percent) of the subjects, including the Athletic Director, stated that "yes, the coaches recruited". Four of those interviewed ( 12 percent) thought that there was a "less concentrated or limited effort" made to recruit whlle one stated ( 3 percent) that the coaches were "semi-active" in recruiting. 
GRAPH 8

Interview Question \#6A: As a department is there (or As a coach is there or Does your coach make) a concentrated effort to recruit talented athletes?

\section{NUMBER OF RESPOHSES}

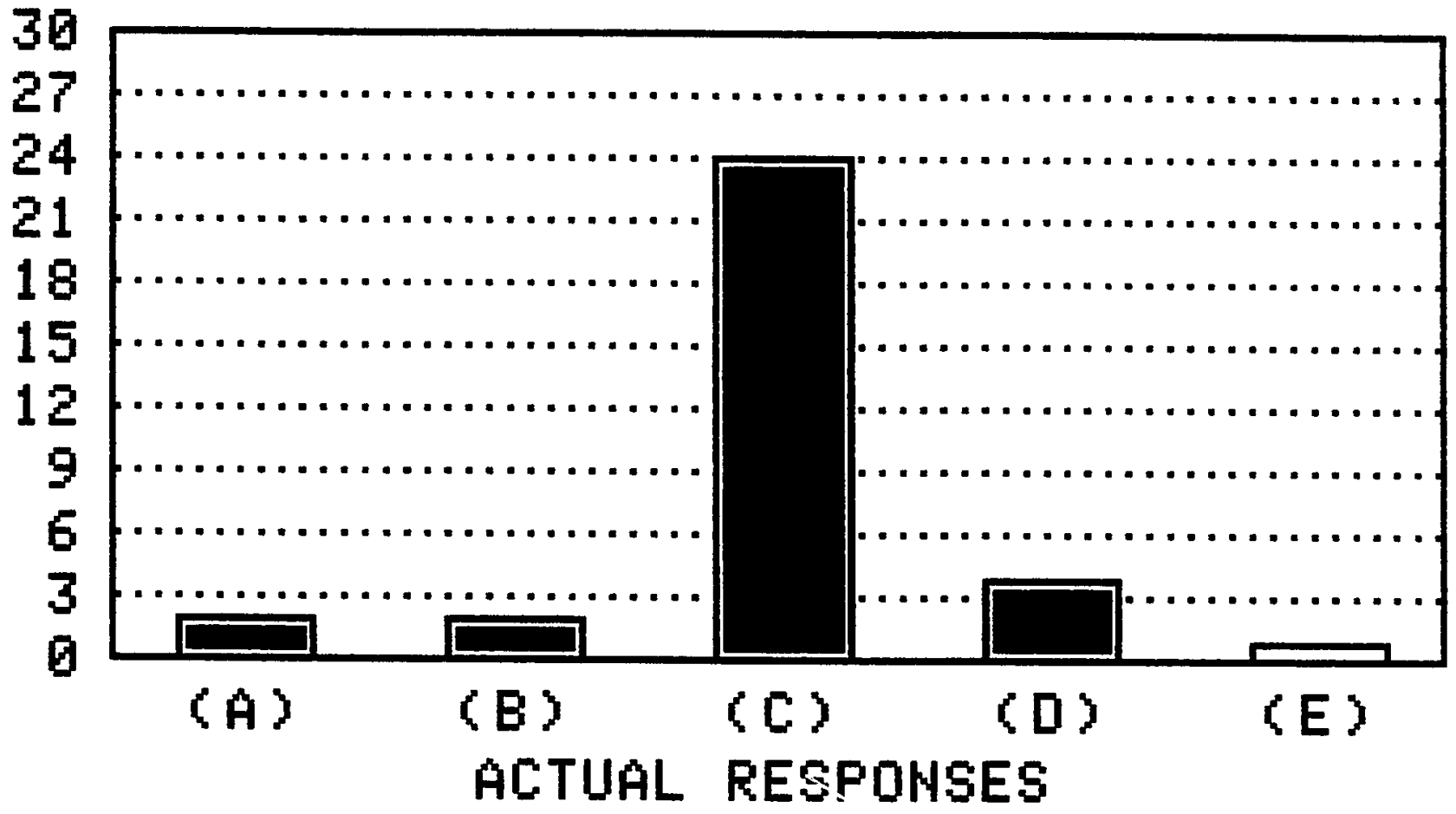

(A) Very Concentrated

(B) Definitely does

**(C) Yes

(D) Limited, less concentrated

(E) Semi-active

**Athletic Director's response

Percent of agreement $=.800$

Total number of responses in agreement $=32$ of 40 
The results of question $6 A$ show that not only was there an 80.0 percent agreement between the Athletic Director and the forty coaches and athletes interviewed but that almost three-quarters (73 percent) used her exact word. Visually this agreement can be seen by comparing the size of bar three in relationshlp to the others in graph 8 .

Graph 9 shows how congruent the responses actually were to question 6B. The two responses given ranged from "above average" to "hlgher". Thirty-six, Including the Athletic Director, agreed that the talent represented by the student/athletes was "above average". One of those interviewed ( 3 percent) thought it was "hlgher". These responses show that not only was there a 90.0 percent of agreement between the Athletic Director and the forty coaches and athletes interviewed but that 97 percent used her exact words to describe the represented talent. Visually this agreement becomes even more apparent when viewing the results shown in graph 9.

The Athletic Director agreed in responding to question $12 \mathrm{~A}$ that the coaches in the athletic program were making a "fairly strong commitment" by giving extra effort to the program inspite of the fact that almost all of them are part-time and must support themselves with other positions outside the university. (Appendix F has the Response Analysis Form for this question that gives the significant word response for each interviewee, Thirty-four of the forty people interviewed, or 85.0 percent, agreed that the coaches were giving extra effort beyond what was expected of 
Interview Question \#6B: Based on your knowledge do you feel that the talent represented by the student/athletes in the atbletic department (or on your team) is above average, average, or below average in relationship to other Division II departments (or teams)?

\section{NUMBER OF RESPONSES}

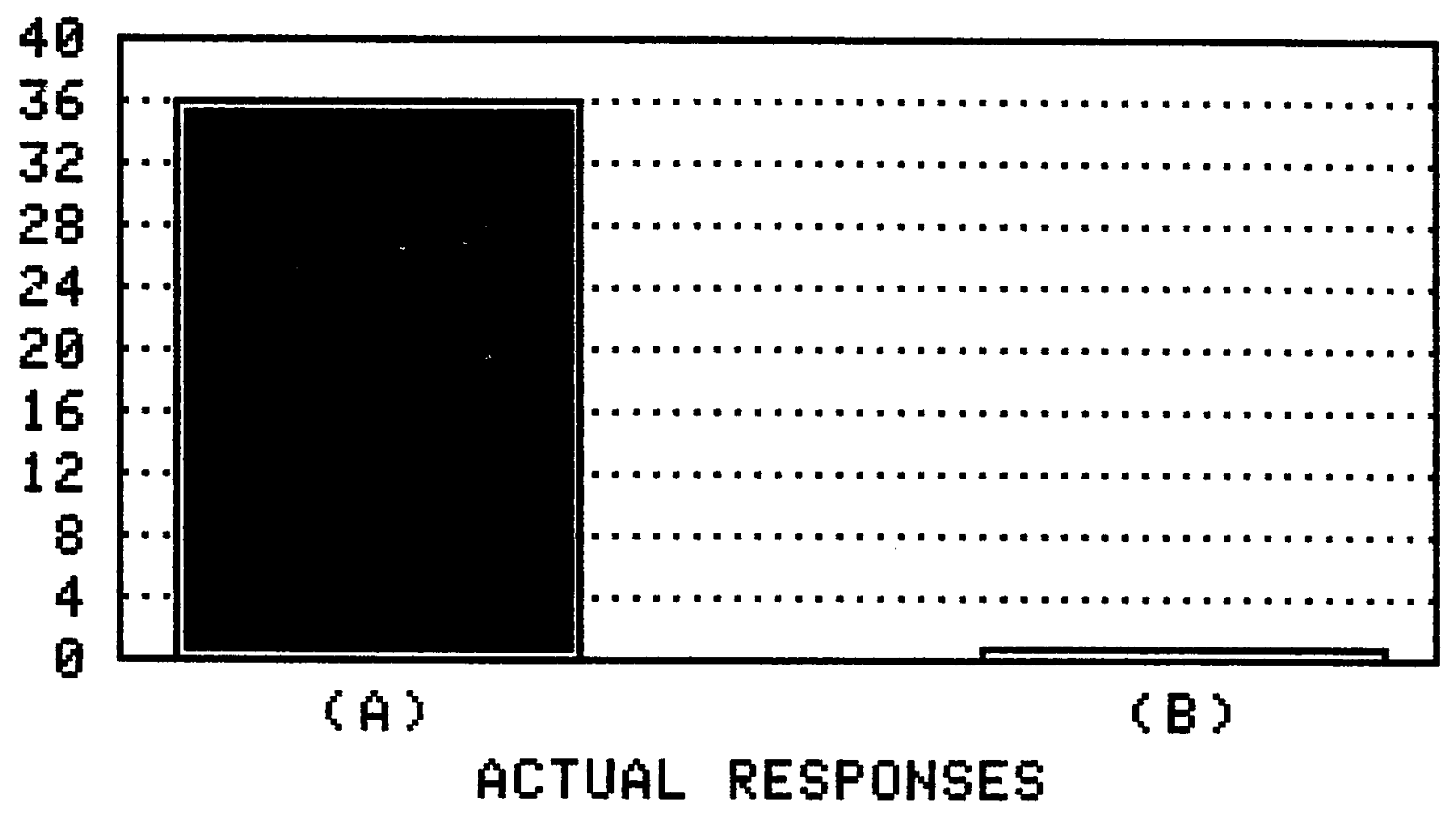

**(A) Above average

(B) Higher

**Athletic Director's response

Percent of agreement $=.900$

Total number of responses in agreement $=36$ of 40 
GRAPH 10:

Interview Question \#12A: Do you feel that the UCSD athletic team coaches (or you as a coach or your coach) give extra effort beyond what is expected of them (or yess or him/her)?

\section{NUMBER OF RESPONSES}

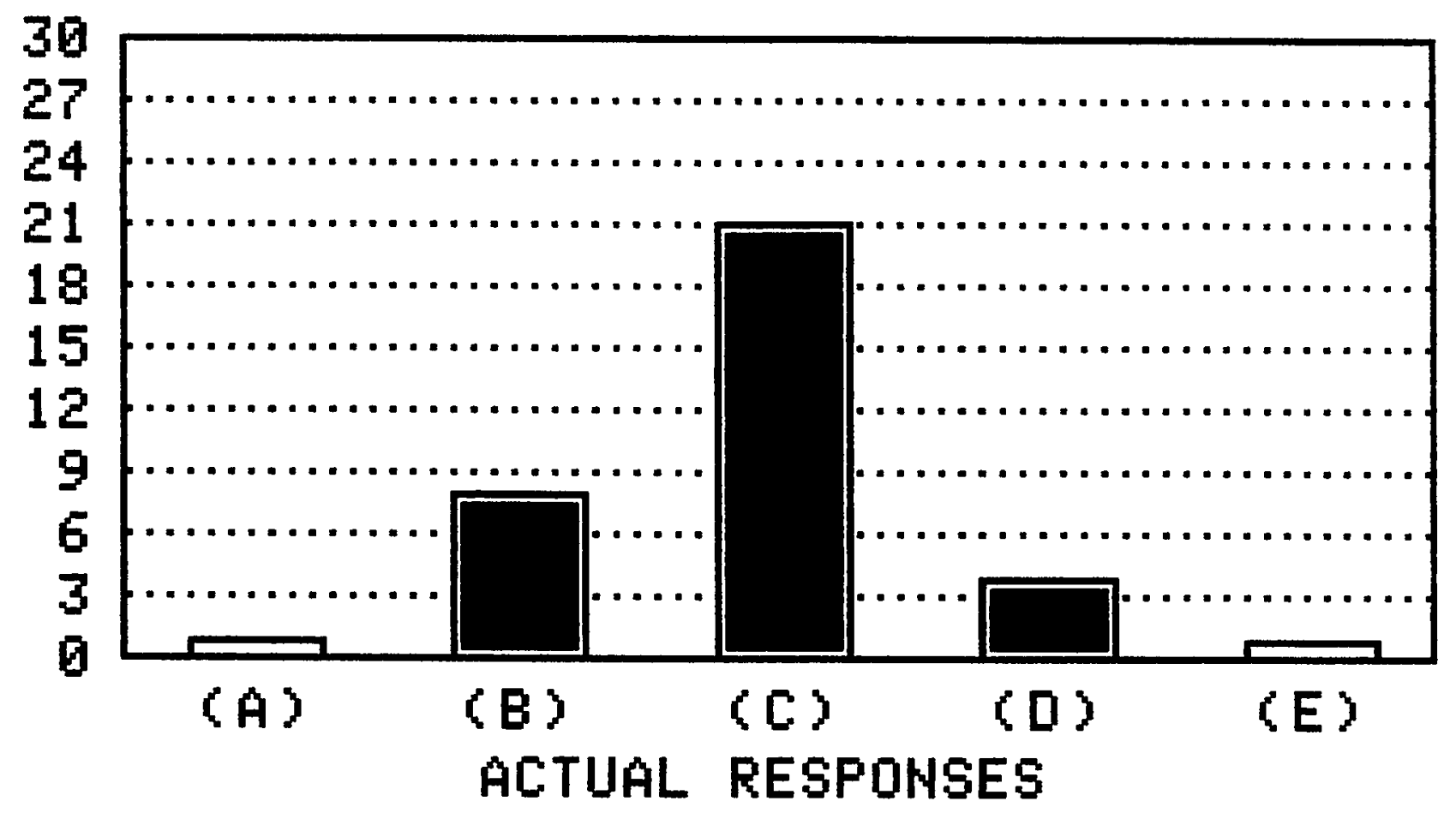

**(A) Making a fairly strong commitment

(B) Definitely/absolutely

(C) Yes

(D) I think so

(E) To a degree

**Athletic Director's response

Percent of agreement $=.850$

Total number of responses in agreement $=34$ of 40 
them.

Graph 10 shows how congruent the responses actually were. The responses ranged from the coaches were making a "fairly strong commitment" to stating that to "a degree" the coaches were giving extra effort. The Athletic Director ( 3 percent) stated that they were "making a falrly strong commitment". Eight of the subjects ( 23 percent) agreed that the coaches were "definitely andor absolutely" giving extra effort. Twenty-one ( 60 percent) stated that, "yes," extra effort was being given. Four of those interviewed (11 percent) responded, "I think so;" whlle one subject ( 3 percent) sald that to "a degree" the coaches were giving extra effort.

The results of question $12 A$ show that al though not one of the forty coaches and athletes interviewed used the Athletic Directors exact words in responding to the question there was an 85.0 percent agreement that the coaches were in fact giving extra effort. Visually agreement becomes quite apparent when viewing bar $C$ in graph 10 .

In responding to question $12 \mathrm{~B}$, the Athletic Director stated that UCSD coaches were committed to the previously stated broad purposes and objectives of the athletic department. (Appendix $F$ has the Response Analysis Form for this question that gives the signiflcant word response for each interviewee.) Thirty of the forty people interviewed, or 75.0 percent, agreed with the Athletic Director that the coaches were commltted the goals and purposes of the athletic department. 
Interview Question \#12B: How committed do you feel the coaches are (or you are or your ceach is) to your previously stated broad purposes and objectives of the athletic department?

\section{NUMBER OF RESPONSES}
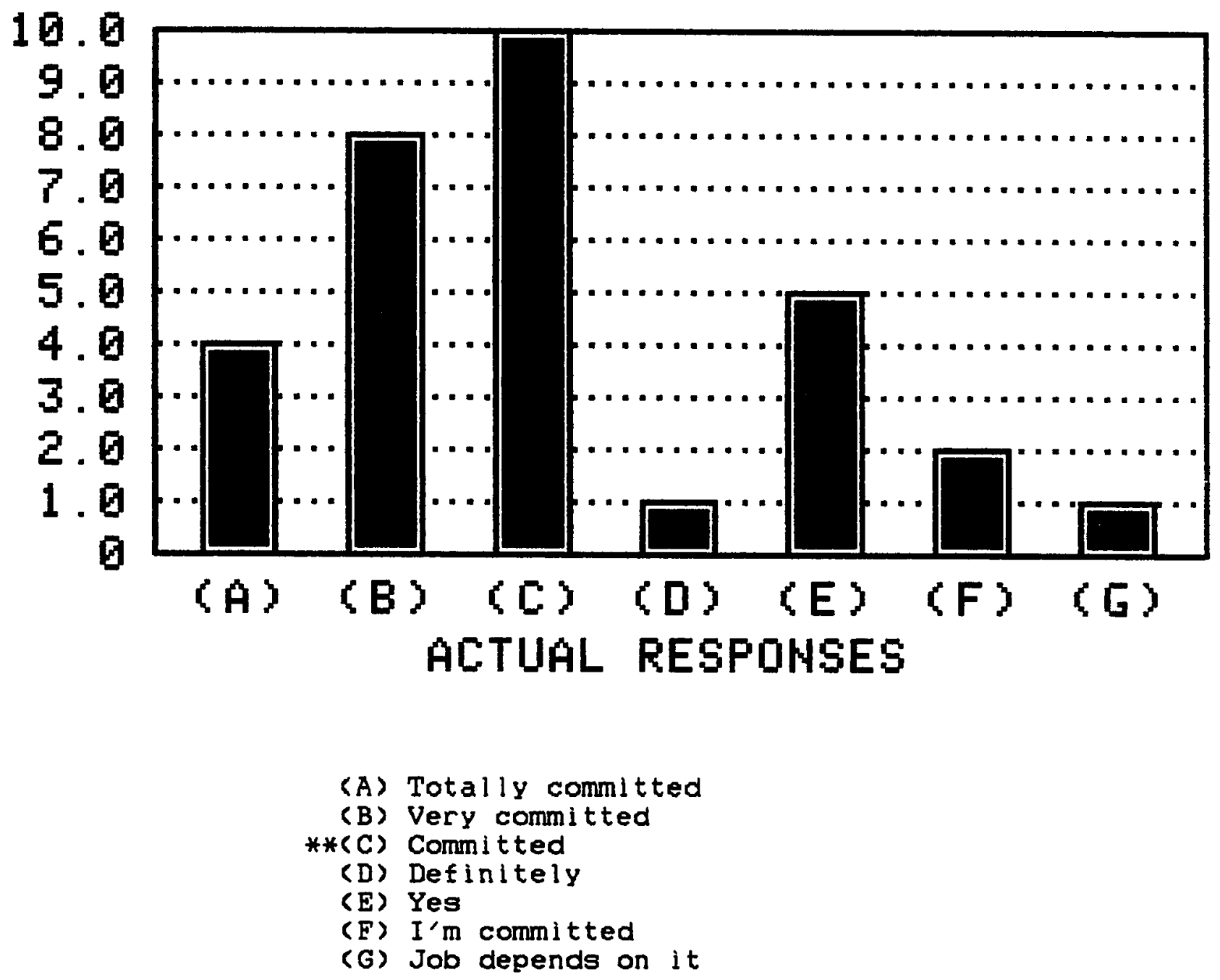

**Athletic Director's response

Percent of agreement $=.750$

Total number of responses in agreement $=30$ of 40 
Graph 11 shows how congruent the responses actually were. The responses ranged from agreelng that the UCSD coaches were "totally committed" to departmental goals and purposes to "their Job depends on being commltted" to the broad purposes and goals of the department. Four of the subjects ( 13 percent) agreed that the coaches were "totally committed". Elght responses (26 percent) thought that UCSD coaches were "very committed". Ten (32 percent) of the subjects, including the Athletic Director, stated that the coaches were "committed" to the goals and purposes of the athletic department. One of those intervlewed ( 3 percent) thought that they were "definitely committed". Five subjects ( 16 percent) personalized the response by stating that "I'm committed". One person ( 3 percent) thought that they had better be comitted because "their job depended upon it".

The results of question $12 B$ show that not only was there an 75.0 percent of agreement between the Athletic Director and the forty coaches and athletes interviewed but that almost one-third (32 percent) used her exact words in describing the coaches commitment. If, though, the word committed is considered, regardless whether it is the entire response or a part of a response, twenty-two people (73 percent) agree with the Athletic Director. Visually this agreement is shown in bars $A, B$, and $C$ in graph 11.

The Athletic Director stated in question $12 \mathrm{C}$ that the coaches for the most part were "very motlvated". (Appendix F has the Response Analysis Form for this question that 
gives the signiflcant word response for each interviewee.) Thirty-three of the forty people intervlewed, or 82.5 percent, agreed with her that the coaches were motivated. Graph 12 shows how congruent the responses actually were. The responses ranged from the coaches were "extremely motivated" to they are "highly motivated". Two of the subjects ( 6 percent) agreed that they were "extremely mot Ivated" - Elghteen responses ( 53 percent), including the Athletlc Director, though the coaches were "very motivated". Eleven ( 32 percent) of the subjects stated that they were "motivated". One of those interviewed ( 3 percent) characterized the motivation as being "very high". Two (6 percent) thought the coaches were "hlghly motivated".

The results of question $12 \mathrm{C}$ show that al though only elghteen or 53 percent used the Athletic Director's exact words in their response, if just the word motivation is used as a gulde, thirty-one (or 94 percent) of those responding were in agreement with her. Visually this agreement is seen by the number of bars that show the word motivation as part of the subject's response. (See bars A, B, and C of graph 12.)

In summary, the results of questions $6 \mathrm{~A}$ and $6 \mathrm{~B}$ show a commitment on the part of the coaches to recruit and find the best possible athletes. The coaches indlcated that they were motlvated to find the best athletes so that they could win. This is not something that appears to them to be a routine activity. Their success in this endeavor is shown by the 97 percent agreement response that shows that the 
Interview Question \#12C: How would you describe the motivation of the coaches? (coaches only: How motivated are you? )

\section{NUMBER OF RESPONSES}

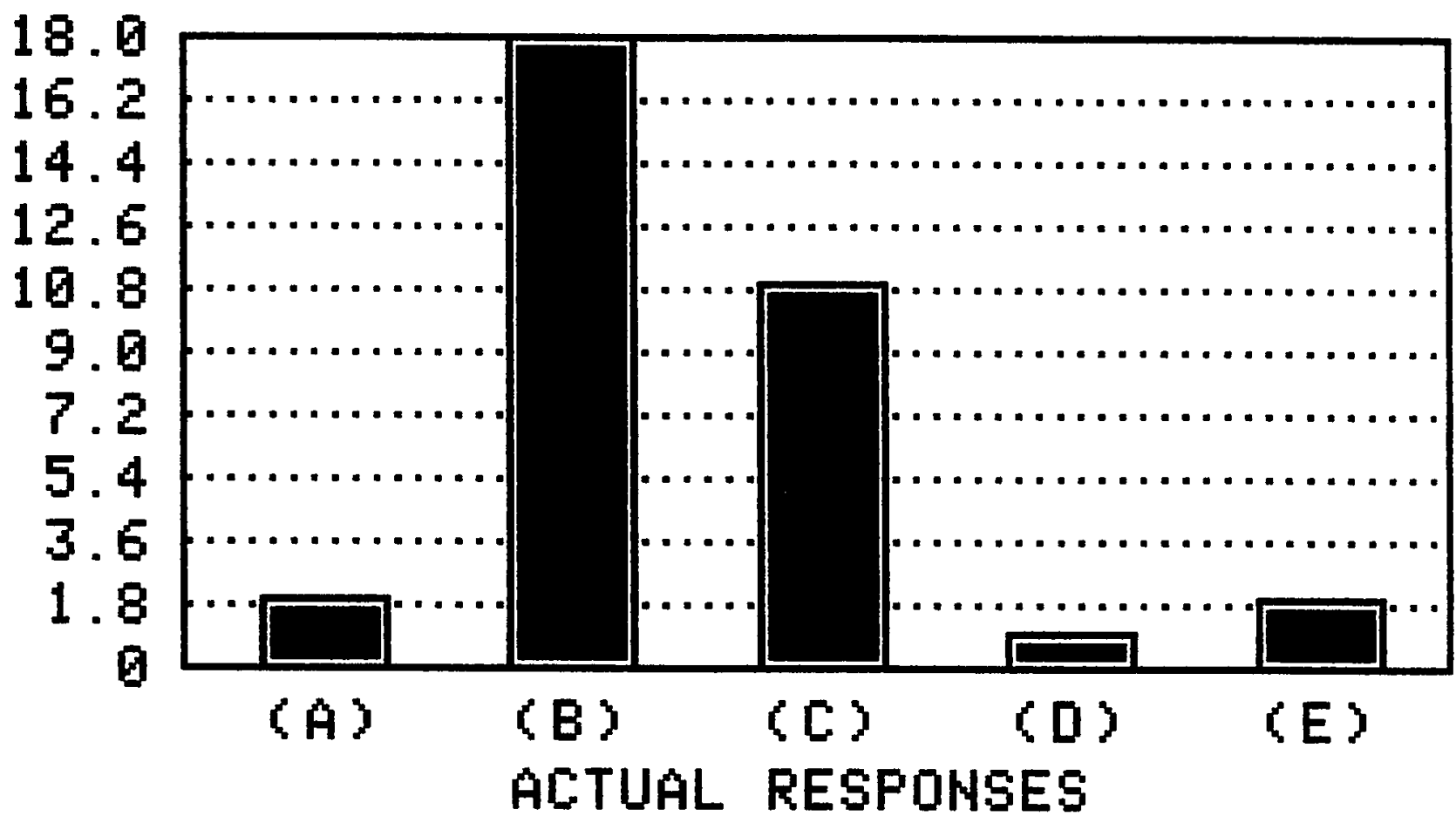

(A) Extremely mot lvated

**(B) Very motivated

(C) Motivated

(D) Very high

(E) Highly

**Athletic Director's response

Percent of agreement $=.825$

Total number of responses in agreement $=33$ of 40 
student/athletes on UCSD's teams represent above average talent when compared to other Division III teams. The responses to question $12 B$ indlcate that 76.0 percent of those interviewed felt that there was a definlte commitment on the coaches part to the stated purposes and objectives of the athletlc department. The use of such terms as totally, very, and definitely by the Intervlewees, when they were describing the commitment, indicates that the commitment they were describing was not perfunctory on the coaches part. Questions $12 \mathrm{~A}$ and $12 \mathrm{C}$ address the contention that Vall makes, in his characteristic two, that the motivation as usually concelved is always high. In question $12 \mathrm{~A}, 85.0$ percent of those Interviewed agree that that the coaches give extra effort beyond what is expected of them. Twenty-three of those who expressed agreement for 68 percent) stated, in response to question $12 \mathrm{C}$, that the coaches were either extremely, very, or highly motivated. Therefore, it can be said that the people in the UCSD athletic department are comnitted to the purposes of their program and this commitment should not be seen as being routine. Additionally, the members seem to see the motivation within the department as belng high.

Intervlew Question 14A: How often do you meet with your direct supervisor for the individual whose cesponsibllities include the athlet le department)? (Omit this question for team members.) 
Interview Question 148: How much autonomy do you have in your position?...Are you often reviewed? COmit this question for team members.)

Interview Question 14C: As a department (or ceach), do you have any interactlons with other departments within the university- elther through formal or informal contacts? (Omit this question for the team members.) These questions are related to Valll's (1984) slxth characteristic for hlgh performance systems: HPS are clearly bounded from their environments, and a conslderable amount of energy, partlcularly on the part of leaders, is usually devoted to maintalning these boundarles (p.86).

The Athletic Director stated that she has had the same supervisor for the last eleven years and that it was only this year that they are scheduled to meet on a regular basis. However, she indicated that during these monthly meetings most of the discussion often centers on the physical education department rather than on the athletic department. As for meeting anyone higher up in the administrative structure, the Athletic Director stated that she must initlate the meetings. (Appendix $F$ has the Response Analysis Form for this question that gives the significant word response for each interviewee.) Only one of the ten coaches intervilewed, or 10.0 percent agreed with her that they don't meet "often enough" or they meet "rarely" with their direct supervisor.

Graph 13 shows the nlne responses of the coaches that did not agree with the Athletic Director's response. The 
Interview Question \#14A: How often do you meet with your direct superviser (or the individual whose responsibilities include the athletic department)? (Omit this question for team members.)

\section{NUMBER OF RESPONSES}

3.0
2.7
2.4
2.1
1.8
1.5
1.2
0.9
0.6
0.3
0

0
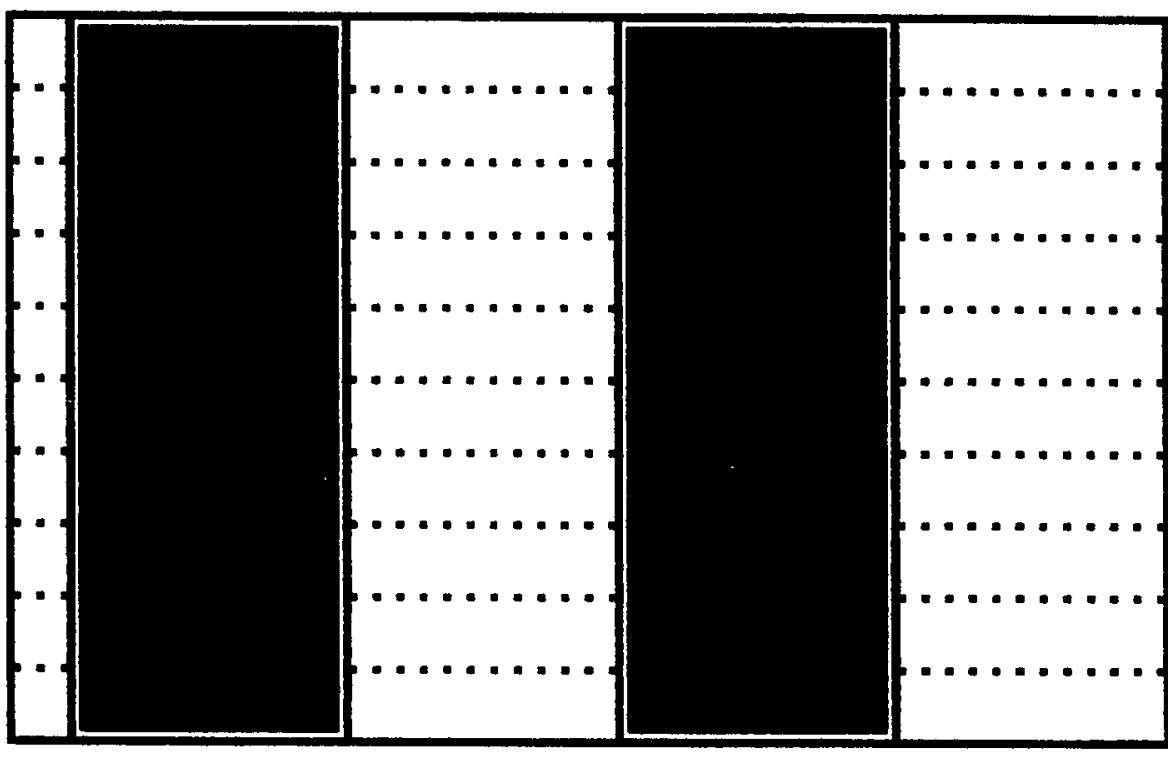

(A)

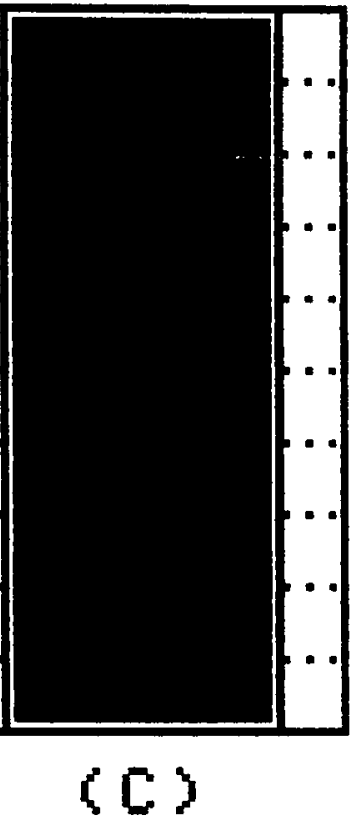

ACTUAL RESPONSES

(A) Once a month

(B) Every two weeks

(C) Weekly

**Athletic Director's response

Percent of agreement $=.100$

Total number of responses in agreement= 1 of 10 
responses ranged from stating that they meet with the athletlc director "at least once a month" to meeting with her "weekly". Three of the subjects ( 33.3 percent) agreed that they meet "at least once a month". Three subje (33.3 percent) responded that they met "every two weeks". Three ( 33.3 percent) of the coaches stated they met with the Athletic Director weekly.

The results of question $14 \mathrm{~A}$ showed a marked disagreement between the response the Athletic Director gave and the statements that the coaches made. These disparlties, however, relnforce the suggesticn by Valll that HPS are clearly bounded from their environment. The limited contact that the Athletic Director has wlth other administrators outside the department could account for the lack of communication and awareness by the outside administrators. This, then, would help to more clearly define the boundarles of the athletlc department. In comparison, graph 13 shows that, within the department, there is a clear attempt to maintain open channels of communication. This is accomplished by the Athletic Director and the coaches meeting often. These frequent meetings are used to desseminate departmental information and exchange personal opinions.

The Athletic Director stated, in responding to question $14 \mathrm{~B}$, that she had "a lot of autonomy" In leading her department. She also stated that she is reviewed "once a year and that this evaluation was conducted by the physical education faculty and chair as opposed to an administrative 
Interview Question \#14B: How much autonomy do you have in your position?... Are you often reviewed? COmit this question for the team members.)

\section{HUMBER OF RESPONSES}

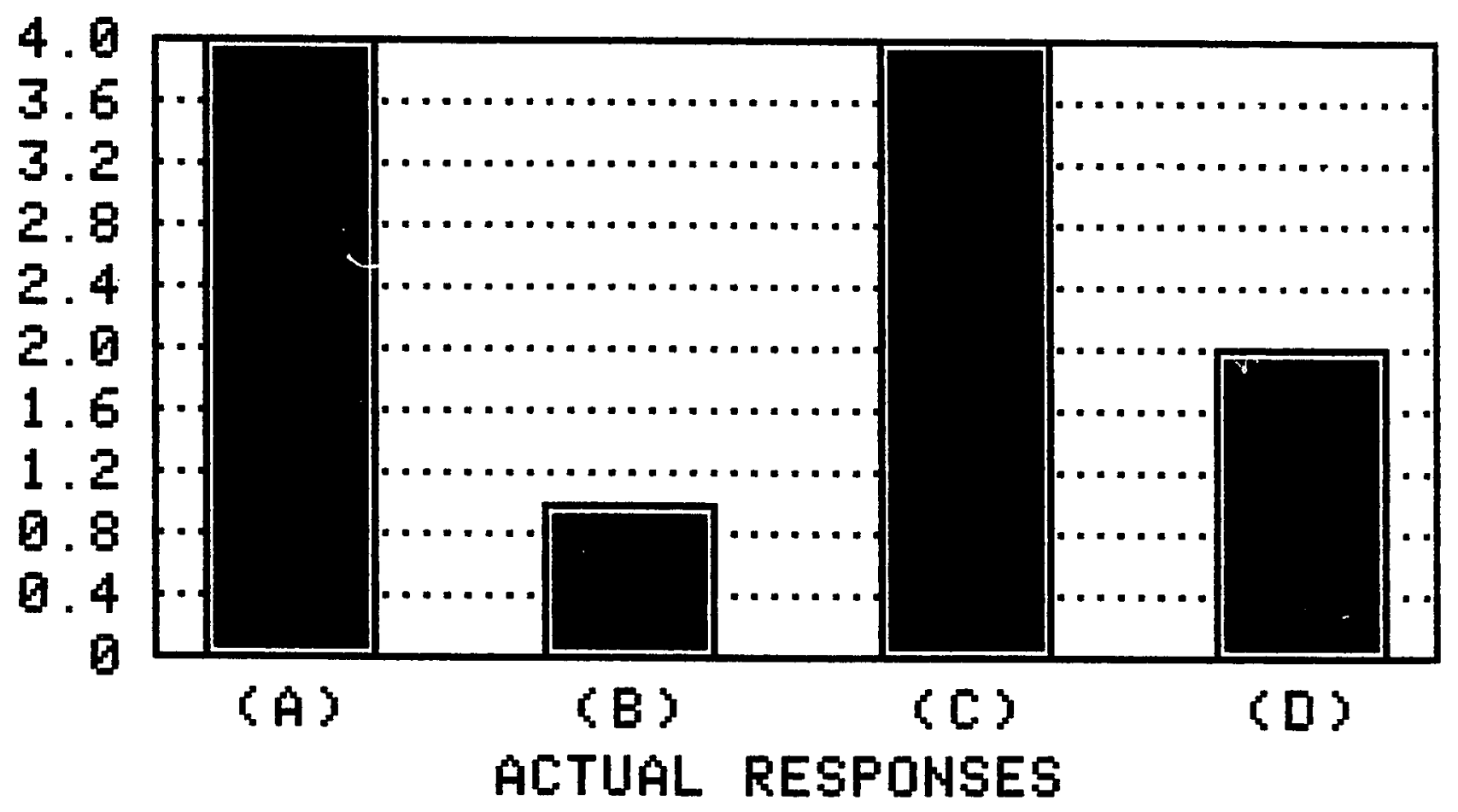

(A) Total control, annual review

(B) Very much, annual review

**(C) Alot, annual review

(D) Quite a bit, annual review

**Athletic Director's response

Percent of agreement $=1.000$

Total number of responses in agreement $=10$ of 10 
revlew". CAppendix F has the Response Analysis Form for this question that gives the significant word response for each interviewee.) Ten of the ten coaches interviewed, or 100 percent, agreed with her that they had "a lot of autonomy" in their position and in running their own program. All of the coaches stated that they are formally reviewed on an annual basis.

Graph 14 shows how congruent the responses actually were. The responses ranged from stating that they had "total control" and were reviewed "annually" to coaches feeling that they had "quite a blt of control" and were reviewed "annually". Four of the coaches ( 36.5 percent) agreed that they had "total control" of their programs and were reviewed "annually". One ( 9 percent) coach thought he/she had "very much" autonomy whlle being revlewed "annually". Four ( 36.5 percent) of the subjects stated that they had "a lot" of autonomy and were reviewed "annually" while two (18 percent) of the coaches characterizing themselves as having "quite a blt" of autonomy and whlle being reviewed "annually".

The results of question $14 \mathrm{~B}$ show that there was a 100.0 percent agreement between the Athletic Director and the coaches that all had autonomy over their own portion of the athletic program. However, this autonomy would further separate the athletic teams and the department from the surcounding unlversity environment because of the lack of supervision and Interest shown by the administrators outside of the athletic department. 
In answering question 14C, the Athletic Director stated that the UCSD athletic department had the most contact with the departments under "student affairs" rather than with any of the "academlc departments". (Appendix F has the Response Analysis Form for thls question that gives the slgniflcant word response for each interviewee.) Ten of the ten coaches Interviewed, or 100.0 percent, agreed with her that the athletic department had almost no interactions with any of the academic departments.

Graph 15 shows how congruent the responses actually were. The responses ranged from stating that there was "no relationshlp" with the academic departments to which non-academic department they did have a relationshlp with. Two of the coaches ( 18 percent) stated that, "no", they did not have a relationshlp with any academic department. One ( 9 percent) subject indlaced that in fact they were "not welcome by the academic area". Two responses (18 percent) centered on the physical education department. These coaches felt that the only reason why they had a relationship with this department was because they "taught some classes" in the physical education department. One ( 9 percent) coach stated that the relatjonship was "not extensive". Four of those intervlewed ( 37 percent) commented that the relationshlp involved the "housing and maintenance departments", whlle the Athletic Director 89 percents thought that the main relationship occurred between the "athletic department and student affalrs departments". In summary, the responses of question $14 \mathrm{C}$ reinforces 
Interview Question \#14C: As a department (or coach), do you have any interactions with other departments within the university - elther through formal or informal contacts? (Omit this question for the team members.)

\section{NUMBER OF RESPOHSES}
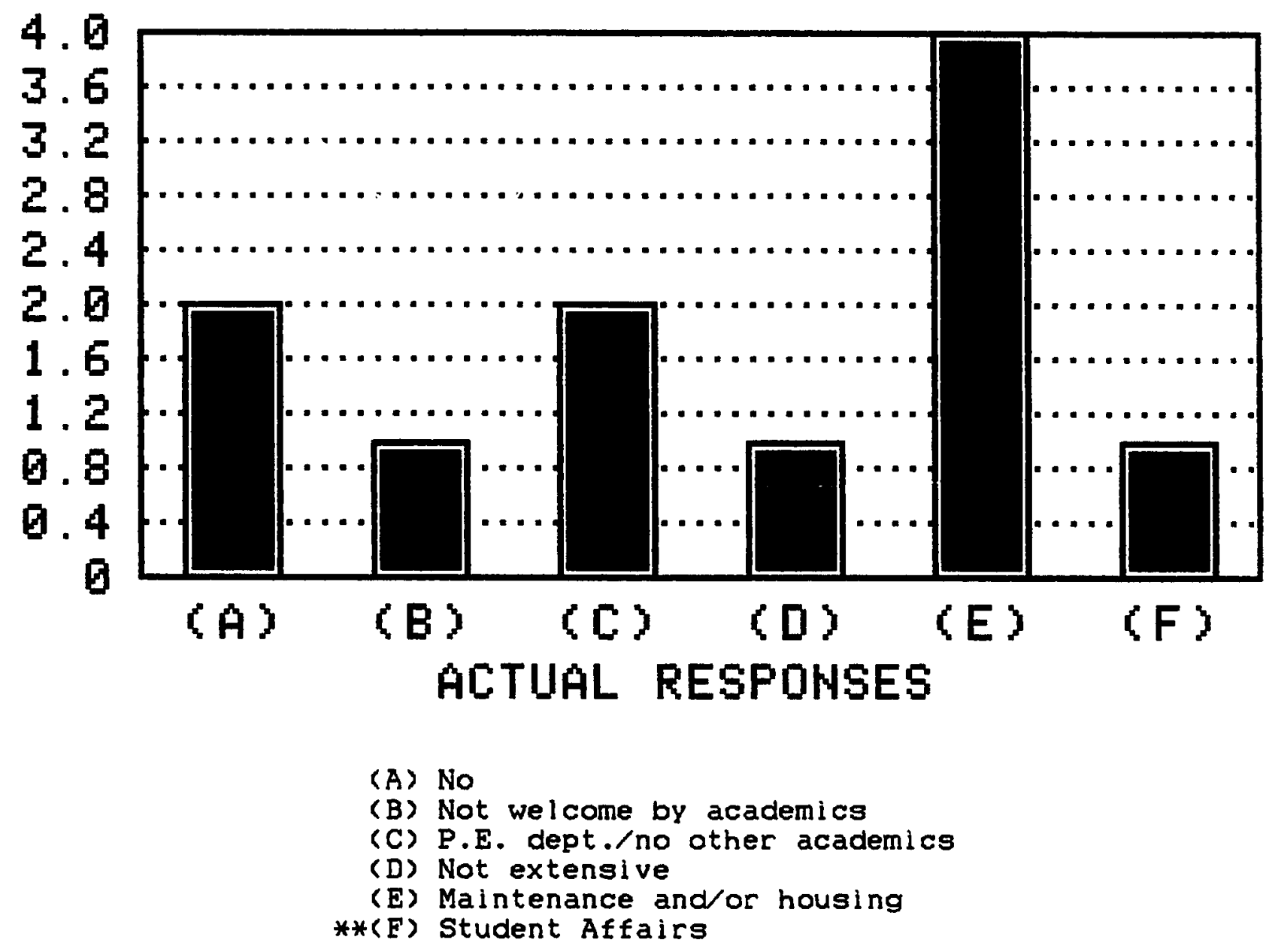

**Athletic Director's response

Percent of agreement $=1.000$

Total number of responses in agreement $=10$ of 10 
the results achleved by questions $14 A$ and $14 B$, that is, that a HPS is clearly bounded from their environment. In question $14 \mathrm{~A}$ the responses suggesting the lack of interdepartmental and intersupervisory communication help to increase the nonpermeabllity of the interorganizational boundary of the athletic department. In response to question 14B, the coaches and athletic director all stressed the amount of autonomy they had in their jobs. In the Athletic Director's case, the autonomy she experlenced comes from the lack of supervision she indicated in responding to question $14 \mathrm{~A}$; as well as the lack of acknowledgement, by the administrators outside the department, of what she does as the administrator of the athletic department. The Athletic Dlrector reinforced her statement by indicating that her annual evaluation did not even warrant administrative review of the job she did as athletic director. In comparison, the coaches stated that they $1 \mathrm{lked}$ the autonomy they were given because it allowed them to do thelr job in the manner that they saw $f$ it. Thus, the coaches saw the autonomy of their job as being something positive and necessary in order for them to achieve success in their positions. Finally, the responses glven to question $14 \mathrm{C}$ show which departments, within the university, the athletic department has any dally relationship with. Most of the departments named, by those interviewed, fell into the support category rather than into an academic category. Therefore the responses glven to questions $14 \mathrm{~A}, 14 \mathrm{~B}$, and $14 \mathrm{C}$, support Vall1's characteristic concerning a HPS being clearly bounded from their 
environment. Whether or not the leaders devoted a considerable amount of energy to maintaining these boundaries could not be ascertained by the results of this research .

Interview Question 15A: How would you describe how the rest of the unlversity percelves the athletic department; for example, the academic area? This question is related to Vall1's (1984) seventh characterlstlc for high performance systems: Proposition ( 6 ) leads to another conslstent finding, that is that HPSs are often seen as a "problem" by entities in their environment, even entities which have a great deal of power over them.

The Athletic Director stated that the academic departments are into their "own world and for the most part are unaware of the athletlc department". (Appendix F has the Response Analysis Form for this question that gives the signiflcant word response for each interviewee.) Thirty of the forty people interviewed, or 75.0 percent, agreed with her that the rest of the university was not really aware of what the department does or even how many athletic teams it has.

Graph 16 shows how congruent the responses actually were. The responses ranged from the rest of the university being "unaware" of the department to they think we are a "thorn in their side". Seven of the subjects $(22.5$ percent), Including the Athletic Director, said that the rest of the institution was either "unaware" of the 
GRAPH 16:

Interview Question 15A: How would you describe how the rest of the university perceives the athletic department; for example, the academic area?

\section{NUMBER OF RESPONSES}

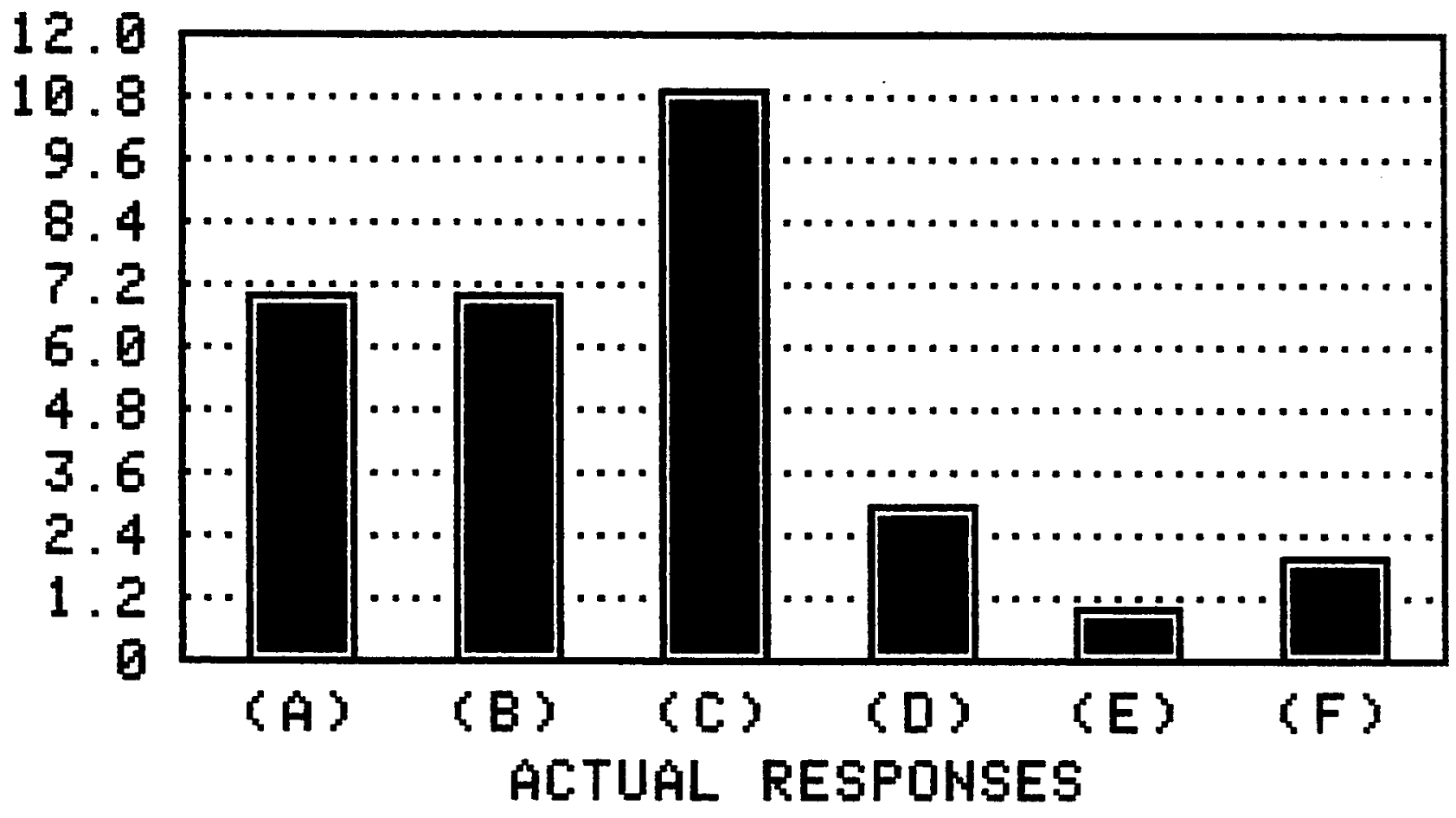

**(A) Unaware/nonexistent of us

(B) Doesn't care

(C) Don't know/lgnorant

(D) Not a major focus

(E) Look at sports in an academic nature

(F) Thorn in side

**Athletic Director's response

Percent of agreement $=.750$

Total number of responses in agreement $=30$ of 40 
department or thought of the athletic department as being "nonexlstent". Seven of those who responded (22.5 percent), thought that as an Institution UCSD didn't "really care". Eleven (35 percent) of the subjects stated that the rest of the university "did not know" and were "ignorant" about the athletic department. Three of those interviewed (10 percent) agreed that athletics was "not a major focus" at UCSD. One person ( 3.5 percent) observed that at UCSD sports is looked upon in an "academic nature". Two subjects ( 6.5 percent) said that the rest of the unlversity thought that athletics was a "thorn in their side".

The results of question 15A show that there was a 75.0 percent agreement between the Athletic Director and the forty coaches and athletes interviewed that the rest of the unlversity was basically unaware of the athlet lc department and its activities. Although there was a concensus among those that responded that the institution was unaware of them, only two subjects thought that the athletic department was a thorn in the side of the academic departments. Although this minority agreed with Valll contention of a HPS often being seen as a problem by enititles within their environment, most of the people interviewed indicated that the athletic department could not be seen as a problem by the universlty because most of people in the academic area are unaware of the department's existence.

Summary: This chapter has presented the results of the data analyses. The chapter began with a review of the 
purposes for conducting this case study and a brief explanation about the data collectlon and why certain responses were chosen to be analyzed. Research questions one and two were then presented in order to see whether or not the data collected would elther prove or disprove these hypotheses.

of the thirty-four interview questions asked by the researcher, the responses to elghteen of the questions attained at least a seventy percent agreement rate between the Athletic Director and the forty coaches and athletes interviewed. The responses to seventeen of the questions agree with Valli's stated criterla cone, three, four, flve, seven) and characteristics (one, two, and $s(x)$ concerning hlgh performing systems. However, one question did achleve the necessary seventy percent agreement rate but did not support Valll's seventh characterlstlcs- HPSs are often seen as a "problem" by entities in their environment, even entities which have a great deal of power over them (1982). The subjects stated that the athletic department was not seen as a problem by the rest of the university. Appendlx $G$ has a list of the sixteen questions not used in the analysis of data because they did not achieve a 70 percent agreement between the Athletic Director and the forty coaches and athletes interviewed. However, some of these questions could be said to support the criterla and characterlstic of high performance systems if they were to be analyzed in different ways: 
1. Questions $10 \mathrm{~B}, 1 \mathrm{BD}$, and $15 \mathrm{~B}$ had an agreement reponse rate of 60 percent or more $(60 \%, 65 \%$, and $67.5 \%)$. Respectively, they needed four people, two people, and one more person to answer in agreement in order to achieve the 70 percent level. The responses to these questions were Influenced by two coaches and the six athletes that consistently disagreed with the responses glven by the Athletic Director. Interestingly all these subjects were part of two of the more unsuccessful UCSD teams.

2. Question 13C had only a 12.5 percent agreement between the responses of the Athletic Director and those interviewed. But this percentage did not reflect the congruence that did occur. The Athletlc Dlrector responded "that she would like more commitment" to the task of the athletic department from the individual above her in the hlerarchy. However, 88.5 percent of the coaches and athletes disagreed with her because they felt that the individual above them in the hierarchy was "committed" to the task. The individual they were talking about was the Athletic Director. Although this questlon did not achleve the Initial necessary agreement percentage it did show a strong commitment by the Athletlc Director to the task of the athletlc department.

3. In answering question 8,45 percent of those interviewed agreed with the Athletic Director that the UCSD teams'uniforms, equipment, and travel schedules were average. However, if you look just at the responses of the ten coaches, 70 percent, of them, thought that these items 
were below average. As stated previously, coaches are usually more aware of what the school provides and what they purchase than the athletes. Athletes are usually unaware of what was purchased by whom. Based on this 70 percent response rate it could be sald that UCSD athletic teams were using fewer resources than it is assumed they need when comparing them with other Division III teams.

4. Question $9 A$ recelved a 2.5 percent of congruence. Although only one subject agreed with the Athletic Director, twenty-six athers, or 65 percent, agreed that other teams respected UCSD and thought that UCSD flelded strong teams. These responses suggested that UCSD was considered an exemplar in Division III and an inspiration to others.

5. Question 2 was worded in such a way that an agreement percentage could not be calculated. Therefore, the information for this question was recorded in Appendix D. This information showed that UCSD was performing excellently against a known external standard.

Thus, in analyzing these seven questions in different ways it could be sald that they support Valll's (1982) criterla and characterlistics of high performance systems. Thus, actually only nine of the thirtyfour questions asked during the interviews did not support Valll's suggested criterla and characterlstics.

Chapter $V$ reviews the case study and examines these results. Research questions three and four will also be discussed because answers to these questions are not based on hard data but rather inferences and conclusions drawn 
from the data. From this examination, conclusions are made and a new interpretation of hlgher education organizational theory will be presented. Chapter V ends with recommendations for future studies. 


\section{CHAPTER $V$}

SUMMARY, CONCLUSIONS, AND RECOMMENDATIONS

Chapter $V$ is divided into seven sections. The first section examines and sumnarizes the purposes of this case study. The second section addresses conclusions drawn regarding research questions one and two. The third and fourth sections discuss research questions three and four respectively. Hypotheses three and four were not examined in Chapter IV because the conclusions drawn concerning these questions are based on information gathered that did not relate to the questions asked during the interview. Rather the conclusions are suggested by inferences and incidental data given by the forty-one subjects interviewed. The fifth section discusses the implications of the findings on present theory concerning higher education organizations. Section six ldentifles recommendations for future research, and the last section offers a summary of the research.

SUMMARY OF THE PURPOSES OF THE CASE STUDY

One of the purposes of this case study was to look beyond the descrlptive theories of organized anarchy and loose coupling and $f$ ind a possible explanation of how excellent performance can occur in a higher education 
organization descrlbed as anarchic and loosely coupled. This case study examined the University of California, San Diego's (UCSD) athletic department whlch year after year produces excellence despite the so-called anarchlc quality of higher education organizations.

A second purpose of thls study was to demonstrate empirically that an example of Valll's high performance system can exist within the university-higher education organlzation. Although this model is not presently used to describe the university and could therefore be considered a competing way of looking at the organization and how it performs, it is hoped that by finding an empirlcal example of thls model within the university lts organizational structure will be given greater clarity of understanding. CONCLUSIONS: RESEARCH QUESTIONS 1 AND 2

Research Question \#1: Can an athletic department be found, within the university-higher education organization, which can be characterized as a high performance system?

Research Question \#2: If so, what makes it a high performance system?

The questlons asked the Athletic Director, coaches, and athletes of the UCSD athletic department during the interviews were directly related to Vaill's (1984) suggested criteria and characteristlcs of high performance systems.

Table 1 represents the findings of the research. It shows which questions/responses reflected Vaill's stated 
criterla and characterlstics of hlgh performing systems. Out of the thirty-three questions asked during the intervlew, sixteen responses supported hls crlterla and characteristics. Five of the criteria and three of the characteristlas were identifled as existing within the UCsD athletic department.

It is Vaill's (1984) contention that a system can be defined as high performing which meets only one of hls stated criteria and characteristics $(p .86)$. Therefore, it is the conclusion of this research that, using Vaill's definition, the UCSD athletic department can be defined as a hlgh performance system because elght criterla and characterlstics were identified.

CONCLUSIONS: RESEARCH QUESTION 3

Research Question \#3: If an athletic department is found to have characteristlcs of high performance systems, how did it achleve this level of excellence?

Educational institutions in the United States do not exist in a static world but in an environment that is Influenced and framed by the events outside those organizations. The modern environment, because of the complexity of modern society, is in a continuous state of flux. Therefore, the relationshlp between the school and the environment must also be constantly redefined in order to keep up with this modern complexity (Abbot, 1975, p.176). ...education is one of the major institutions in American society today. As such, education is firmly 
VAILL'S

CRITERIA :

1.Performing excellently against external standard.

3.Performlng excellently relative to earlier time.

4. Judged substant lally better than comparat ive systems.

5.Using significantly fewer resources.

7.Fulfill a high level of ideas of culture.

CHARACTERISTICS:

1.Clear on broad purposes 11A.Purposes?

2. Commitment to purposes never perfunctory.

6.HPS are bounded from the ir environment.
$70.0 \%$

TABLE 1

RESEÄRCH QUESTION

* AGREEMENT

1. How compare your performance?

$87.5 \%$

3A\&B. How compare the depart- $97.5 \%$ ment/team when you

first arrived?

4. Judged by others to be better?

$85.0 \%$

5A.Budget? B.Above aver.,

$65.0 \%$ aver., below aver.?

7.Athletic facilities: above aver., aver., below aver.?

$75.0 \%$

10C.Athletic department reflects own culture?

$82.5 \%$

6A. Coaches make effort to $80.0 \%$ recruit?

6B. Talent:above aver.,aver., 90.0\% below aver.?

12A. Coaches extra effort?

$85.0 \%$

12B. Coaches commitment?

12C. Mot I vation coaches?

$82.5 \%$

14A. Meet with supervisor? $10.0 \%$

14B. Autonomy-reviewed? $100.0 \%$

$14 \mathrm{C}$. Interactions $\mathrm{with}$ other $100.0 \%$ departments?

15A. Rest of university percelves ath.dept.?

$75.0 \%$ 
established within the basic fiber of our soclety and culture. Therefore, education can be considered and instrument of cultural needs allowing soclety to get the type of education it wants (Goodman, 1962, p.26; Ross, 1958, p.9).

In the area of athletics, society has historically given colleges and universities a very clear message about what it expects from their intercollegiate programs. It has been suggested by Brubacher and Rudy (1976) that the year 1880 be used as a dividing line between the earlier informal period and the rise of big-time athletlcs in most of the institutions of higher learning in this country. From this date onward coaches tended to become full-time employees of the university and were incorporated into the faculty structure. Athletes were offered grants-in-ald or other financial incentives to compete for an institution. No longer were athletic programs run or flnanced primarily by student associations but rather were funded, at least in part, by institutional or state tax funds. This new situation caused financial demands on athletic programs to rapldly increase, bringing wealthy alumnl, a primary source of new financing, into a very influencial position within some athletic programs. As more and more spectators were attracted to athletic contests, contractual and obllgatory schedules became pro forma in order to control and generate new funds. College presidents also began to be influenced by the increased popularity of their intercollegiate teams. From the very beginning, the general belief of many of the 
presidents was that "an important factor in the drawing power of any American institution of learning was the prowess of lts athletic teams" (p.132).

The Amerlcan emphasis on winning games for their financial or publicity value, the mass enthusiasm of college spirit, stimulated by bands and cheer leaders, the high degree of professional organization and specialization involved in the really "big-time" athletic contests, were in many ways unigue in the world (Brubacher \& Rudy, 1976, p.133). Learning within Amerlcan colleges and universities became organized into both informal education, such as the athletic programs, and into the formal instruction of the academic courses of study. Within this unique arrangement can be seen the powerful Influence of American culture upon the patterns of higher education (Brubacher \& Rudy, 1976, p.410). Thus, the increased interest and importance placed upon intercolleglate athletics by American soclety came to be reflected within the formal structure of collegiate organization.

This ldea of external forces changing the internal structure of an organization has also been proposed by many organizational theorists. Baldridge (1977) states that many theorlsts have decided that one of the prime reasons for large scale change in organizations comes from external pressures $(p, 124)$. Scott (1983) proposes that organizations located in a complex and uncertain environment will exhibit more complex internal structures due to external forces 
(p.172). Welck (1974) goes a step further and feels that organizations "are locked into circults that extend beyond artiflcial boundarles. Environmental events cycle back inslde and rearrange...the organlzation..." (p.358). Finally, Jackson and Morgan state that a powerful determinant on designing internal structure is the external environment (p.260). All these theorlst, then, ldentify external environmental forces as a prime cause for internal structural change thus relnforclng what Brubacher and Rudy stated about the effect of American culture on the structure of collegiate athletics.

Athletics, in comparison to other areas within the university, seems to bring strong external environmental forces to bear upon the university and its structure. UCSD has not been exempt from these pressures. As coach \#8 states, in the $1960^{\prime} s$ the UCSD students voted out football as reflection of their discontent with the establishment and what it stood for in American culture. In athletics football is the very essence of the establishment. This elimination of football as an entity on the campus of UCSD propelled the athletic program back into the realm of intramurals and play days. Slowly, the program was brought back from the intramural emphasis to a national competitive Division III athletic program. Graph 2 in Chapter 4 1llustrates how the subjects interviewed viewed this change: 97.5 percent agreed with the athletlc director that the program had gone from a sports club atmosphere to a national callber Division III program. 
Perhaps the cause of thls change in philosophy at UCsD is that the sports interests within the unlversity are externally linked to the market and political forces in the larger soclety (Hart-Nibbrig \& Cottingham, 1986, p.97). Varlous subjects intervlewed gave examples of these forces that are presently being brought to bear on UCSD to change into an even more competitive program. Athletes \#7B and \#8A didn't feel that UCSD was keeping up with what the students want. What do the students want? It seems that they want to move UCSD from Division III to Division I or II. (See Appendix E which contains a signiflcant article from the school newspaper that reflects this new philosophlcal change.) Fifteen of the forty subjects interviewed gave indlcation where this new perception could have possibly come from. They used the University of Callfornia, Los Angeles (UCLA), which is a Division I institution, as an example of the type of program that UCSD should have and the type of program that they wanted to be a part of. As Baldridge (1971) states:

other education institutions form one of the most important elements in the task environment for any university...An institution's role is often shaped by its relation to others in its reference field, a field that varles greatly for different institutions ( .128 ). UCLA is in UCSD students' reference fleld. Thus, the apparent desire to move UCSD out of Division III seems related to other educational organlzations and thelr views of athletics. This area of organizational-environmental 
relatlonships is perhaps the least developed area in the study of organizations (Carlson, 1975, p.187). Because of these responses given during the interview process a causal relationship between change within the UCSD athletic department and the environment outside is suggested. However, If thls relationship could be moce clearly established, a more definitive answer might be found as to why the UCSD athletic department did reach this level of excel lence.

Another possible clue as to how UCSD reached such excellence could be found in Aldrich and Pfeffer's (1976) discussion on the socletal establishment of perception within a subpopulation of an organization. It is their contention that hiring personnel from the same industry promates within an organization a common frame of reference, a shared perception (p.95). The coaches of UCSD definitely have been hired from the same "industry" and have a "common frame of reference". All the coaches were hired because of their experience within the same industry-intercollegiate athletics. Not only did all the coaches have competitive Intercollegiate experience but some of them competed at professional levels as well. Therefore they came to UCSD with a perception of what athletics was like, what it was supposed to be, and how to achleve the best results. They seemed to have what Aldrich and Pfeffer state as homogenized perceptions (p.95). These congruent perceptions not only influence the unity of the athletlc program at UCSD but affect the future thrust of the athletic department. Since 
all of the coaches either played at the Division I or Division II level, they came into the UCSD athletlc program with a high level of expectation for excellence in athletic performance because of the different emphasis on high levels of performance inherent in Division I and II programs in relationship to a Division III program.

Finally. Abbott (1975) discusses another aspect of organizations that are influenced by external factorslevels of aspiration. He states that the most important source of levels of aspiration within an organization is past performance.

When other factors are held constant, organizations tend over time to adjust their aspirations for performance to coinclde with past performance $(p, 180)$. If Abbott's contention is correct, the past level of performance would have influenced the UCSD athletlc department to maintain it past low level of performance. However, this is not the case. In responding to interview question $3 A$, ninety-seven and a half percent of those interviewed agreed that they were performing better in relationship to their performance in an earlier point of time. However, once they achieved this high level of performance, Abbott's theory of adjusting present aspirations for performance to colncide with past performance makes more sense in explaining how they sustain their present level of excellence.

Perhaps UCSD's increase in performance excellence can better be explained by what Abbott feels is the second 
source of levels of asplration, the comparison the organization makes with other organizations.

In general organizations tend to adjust their levels of aspiration to coincide with the performance achieved by other organlzations with whlch they compare themselves (p.180).

There has been a substantial improvement in the UCSD performance level when compared to that of other Division II schools. Eighty-flve percent of the responses given to question $4 A$ of the interview questions agreed that the athletlc teams at UCSD were performing better than other Division III programs. This improvement could be linked to the stress on winning that is inherent in any athletic contest. It could also be said that UCSD adjusted its level of aspiration to coinclde with the performance achieved by other Division III organizations. The only question that does not seem to be answered In discussing Abbott's theory on level of aspiration within an organization is when does one of these factors becomes dominant over the other factor, thus influencing a change in organlzational performance rather than a continuation in organizational performance?

In responding to research question three, there seems to be many possible answers as to how UCSD, as a high performance system, achleved its level of excellence. From the discussion of the effect of Amerlcan soclety and culture on the establishment of athletics as an integral part of the university to the societal establishment of perception within a subpopulation of an organization and levels of 
aspiration within an organization, it is obvious that the environment outside American universities influence the very structure and subject matter taught within these institutions. It would be safe to say, then, that the environment outside UCSD played a signlficant role in influencing the successful development of the athletic department.

CONCLUSIONS: RESEARCH QUESTION 4

Research Question \#4: How can a high performance system exist in an organization described as an organlzational anarchy and or a loosely coupled system?

In a loosely coupled system "flawed feedback, or the inablilty of the various units to communlcate, is often the major source of looseness" (Welck, 1982, p.402). During the course of this study it became quite apparent that the people interviewed in the athletic department at UCSD did not feel that there was signlflcant communication between their department and the other academic departments within the university. The responses given by the coaches to question 14C found that there was a one-hundred percent agreement between them and the Athletic Director that there was no formal interaction between the athletic department and the academic areas of the unlversity. The only interdepartmental interactions that the coaches acknowledged was with such departments as student affalrs and maintenance. 
Thls research did not address whether or not $f$ lawed feedback was the cause of the lack of communication. However, this research did address the issue of how the rest of the university viewed the UCSD athletlc department and program. The academic departments' vlew of the importance of research within a university established research as the measurement by whlch all departmental activities were evaluated at UCSD. Those departments whose activitles did not involve research were not considered important. This institutional norm stressing the importance of research at UCSD was indicated by the subjects interviewed. One of these subjects felt that everything at UCSD was judged in relationship to the generation and quality of research and since athletics was not involved in any research the department was not considered an important entity with the university structure. Many of the other subjects Interviewed agreed with this point of view and stated further that they felt that the stress on research within the university brought either negative or absent feelings to bear upon the athletic department. Some of the comments of those intervlewed were:

Athletic Director: There are not a whole lot of people that pay a lot of attention to the athletic program. Coach \#1: The academlc community probably doesn't think that we reflect the philosophy of the institution because they see no place for athletics at a school like this. 
Coach \#8: The academic department considers the athletic department as a thorn in their side. Coach \#10: I don't think that most of the people on campus think the athletic department has a lot to do with the culture... is considered a frivolous thing to do.

Athlete \#5B: This school doesn't like athletics. Athlete \#6A: The academic area sees the athletic department as a nuisance.

Athlete \#6B: The academic area don't know we exist. They don't know anything about it... how many teams... what each team did... they just wouldn't know about it. Athlete \#6C: They don't think about the athletlc department at all.

Athlete \#8C: The academic area really dislikes the athletlc program...they don't want the athletic program here at all. Athlete \#9B: I don't think they would find it very worth while to see how the teams perform.

In view of the above responses, it could be stated that the athletic department had difficulty communicating its views and the importance of its activities to the academic portion of the university.

The Athletic Director seemed to also agree that the athletic department has difflculty communicating with the rest of the university. She stated, in response to question $11 \mathrm{~A}$, that she felt that one of the main purposes of the 
athletic department was to generate greater visibility and spirit within the university. Seventy-five percent of those interviewed agreed with her. Thirty-two percent speciflcally stated that the athletic department's purpose was to generate spirit and promote the athletic program within the university. They seem to acknowledge that there is a miscommunlcation and therefore a certain looseness between the their department and the rest of the university. Weick (1982b) and Scott (1981) discuss what effect looseness between departmental units has on the structural elements of an organization. It is their bellef that the looseness provides each departmental unit with the ability to vary independently and be more sensitive to their local environment. This sensitive mechanism can detect variations within their immediate environment (p.387\& p.248). This theorlcal perspective seems to suggest that loose coupling not only encourages unique lacal adaptation but that the adaptation response that does occur is not necessarily the same for each part of the organization. Ouchi (1978) seems to agree with this conclusion when he states:

Given that Individual departments have needs for control that must be tailored to thelr specific tasks, people, historles and microenvironments, it is desirable that each department follow somewhat different protocols for control. Thus inconsistency or loose coupling through the hierarchy is to be expressed and encouraged (p.283). 
Welck (1982a) also feels that loose coupling should be encouraged because it perserves the professional needs for autonomy within an educational organization by allowing novel solutions and local accommodations to occur (p.675). Perhaps this is what Welck (1977b) calls effectlve anarchy:

...effective anarchy?... a unit that telerates the fact that its technology and goals are unclear and that its personnel are transient; is it a unit that makes do Inspite of these circumstances; is it a unit that never ralses effectiveness issues or even uses this adjective; is it a unit that minlmizes the return to the organization, or what $(p .212) ?$

It is this concept of an effective anarchy that is central to the explanation of how a hlgh performance system can exist within an organization described as an organized anarchy and/or a loosely coupled system. Acknowledging that one of the problems of an organized anarchy and a locsely coupled system is the inability of the various units to communicate, the advantage of such systems is that they allow Individual department units to vary independently in response to their environment. The ability of an organlzed anarchy and a loosely coupled system to tolerate novel solutions, local accommodations, and a great deal of ambigulty enabled the UCSD athletic department to develop into a high performance system. The athletic department was able to respond to the performance expectations of its environment and develop a high performance system that was 
able to provide the level of excellence that is expected of athletic teams by people outside the unlversity. Thus it is because the university is an organized anarchy and a loosely coupled system that this development was able to take place.

IMPLICATIONS OF THE FINDINGS ON PRESENT THEORY

Many present-day theorists view the higher education organlzation as being nonrational in nature. Many of them describe the unlversity and colleglate organizations as being organlzed anarchles (March \& Olsen, 1979) that exhibit loosely coupled characteristlcs (Welck, 1982) and reflect fundamental amblgulties (Bolman \& Deal, 1984). Although these theorists describe the university organization in compatible, non-rational terms, the ambigulty that is central to both theories is also central to their theoretical results. They do not tell us why or how the exhibited organized anarchy or loosely coupled characteristics occur. Thus, they seem to eliminate much of the practical application of their theorles. The inability of these theorlsts to explain educational institutions in more clearly definable terms is a central issue involved in this research.

Belng pragmatlc this researcher wanted to understand the educational organization in clearer terms in order to provide a more distinct model for those individuals who must lead these institutions during our present, complex times. This is not to say that organized anarchy or loose coupling are out-dated theoretical terms. Rather it is to realize 
that they are descriptive terms that are describing what is being exhibited within educational organization but not why. As Bennis and Nannus (1985) state "part of the problem is the lack of understanding of the varlous 'organizational selves'... In all organizations" (p.48).

It is this researcher's bellef that higher education organizations have many and varied organizational selves, and that past theoretical error has been to try to explain these organizations in simple, monolith terms. Higher education organizations have very complex organizational structures. The amblgulty exhiblted by these organizations is due in part to the variety of organizational structures that can be found with in the modern American university. Perhaps the higher education organization should be considered as an umbrella organization that provides a loose and external structure whlch allows its varled organizational parts to develop their own distinct structure that best $f$ its their individual environmental needs. The UCSD athletic department developed a high performance systems structure as it adapted to the external American cultural demands that expects a winning program and excellent performance from incollegiate sports programs. Thus, the permeability of educational organizational boundarles allows the environment to intrude and help form the very substructure of the organization itself. ... in most large organizations different subunits face different environments... the more dlverse the environments that different units face, the more 
differentiation in structure is needed (Bolman \& Deal, $1984, p .47)$.

What this researcher is suggesting is that there is a definite differentiation in organizational structure between the various subunits and/or departments within the educational organization. This differentiation is caused by the demands placed the external environment and by the specific tasks these subunits and or departments are being asked to perform. These demands not only influence the structure of this umbrella organzation but also its goals and the participation of lts unlts into the activities of the whole institution.

The goals of the umbrella organization would have to be unclear in order to accomnodate the different subunits' individual goals. The question is to whom are these institutional goals unclear? They could be considered general by the subunits because of their generlc nature. They could be considered unclear by people outside the educational organization if these same people saw the varlous subunits functioning with different goals and purposes. The particlpation, within the umbrella organization, would have to be fluid to enable the various organizational units to participate in umbrella activities according to their own unit needs and purposes. These subunits could therefore have selective participation. A great deal of ambiguity would be exhibited as the different parts of the umbrella organization function using different goals and fluid institutional participation. 
The Impl leations on present organizational theory, of thinking of an educational Institution as an umbrella organization, are clear. It will provide a theoretical basis that wlll assist leaders of educational organizations in having a clearer and more pragmatic view of their own organlzatlons.

RECOMMENDATIONS FOR FUTURE RESEARCH

1. Future research should valldate the interpretation of the higher education organization given in this research.

2. Future research should examine the different subunlts andor departments within the higher education organization to see if another empirical example of a high performance system can be found.

3. Future research should examine if all university and college athletic programs can be identified as high performance systems.

4. Future research should examine the problem created if not all athletic departments can not be identified as high performance systems: why can some athletic departments be identlfled as $h$ lgh performance systems and not others?

5. Future research should address how in an athletic department, identifled as a high performance system, can portions of that department not be performing excellently.

6. Future research should examine higher education organlzations to see if empirical examples of other organizational models can be ldentified within the organizational structure of these institutions. 
7. Future research should examlne whlch forces within the environment of a university or college have the greatest effect on the subunit structure of the organization; i.e., market or political forces, other educational institutions, or societal norms.

\section{SUMMARY OF RESEARCH}

Thls case study revealed that, using Valll's suggested criteria and characteristics as a guide, the athletic department at the University of Callfornia, San Diego could be identifled as a high performance system. In addressing the question of how the athletic department achieved this level of excellence, the findings suggest that the environment outside the university played a significant role in influencing the successful development of the department. The findings also suggest that the athletic department was able to exlst as a hlgh performance system within the university organization because of the ability of an organized anarchy and a loosely coupled system to tolerate novel solutions, local accommodations, and a great deal of ambigulty while still maintaining its own unlque identity. 


\section{REFERENCES}

Abbott, M.G. (1975). The school as a social system: indicators for change. In J.V. Baldridge and D. Deal. Managing change in educational organizations, 176-186. Berkeley, Ca.: McCutchan Publishing Corp.

Aldrich, H.E. \& Pfeffer, J. (1976). Environments of organizations. Annual revlew of sociology, 2, 79-105.

Argyris, C. \& Schon, D.A. (1978). Organlzatlonal learning: A theory of action perspectives, Reading, Mass.: Addlson-Wesley Publishing Company.

Baldridge, J.V. $(1971)$. Power and conflict in the university. New York: Willey Company.

Baldridge, J.V. (1977). Organizational change: Institutional sagas, external challenges, and internal politics. In G.L. Riley \& J.V. Baldridge. Geverning academic erganizations, $123-144$.

Baldridge, J.V., Curtis, D.V., Ecker, G.P. \& Riley, G.L. (1977a). Alternative models of governance in higher education. In G.L.RI ley and J.V. Baldridge. Geverning academic organizations, 2-25. Berkeley, Ca.: McCutchan Publishing Corporation.

Baldridge, J.V., Curtis, D.V., Ecker, G.P. \& Riley, G.I. (1977b). Diversity in higher education: professional autonomy. In G.L. Rlley \& J.V. Baldridge. Governing 173 
academic organizatlons, 42-63. Berkeley, Ca.: McCutchan Publ ishing Corporation.

Baldridge, J.V., (1983). Organizational characteristics of colleges and universities. In J.V. Baldridge and T. Deal. The dynamics of organizational change in education. 38-59. Berkeley, Ca.: McCutchan Publishing Corporation.

Barnard, C. (1939). The functions of the executive, Boston: Harvard Unlversity Press.

Beisser, A. (1970). Modern man and sports. In G.H. Sage. Spert and amerlaan soclety, 235-245. Reading, Mass.: Addison-Wesley Publ lshing Company.

Bennis, W.G. (1976). The unconscious conspiracy: Why leaders can't lead. New York : AMACOM.

Bennis, W.G. \& Nanus, B. (1985). Leaders: the strateales for taking charqe. New York: Harper \& Row, Publ ishers. Bidwell, C.E. (1965). The school as a formal organization.

In J.G. March. Handbook of organizations. 972-1022.

Chlcago: Rand McNally.

Bolman, L. \& Deal, T.E. (1984). Medern approaches to understanding and managing organizations. San

Francisco: Jossey-Bass Publ ishers.

Borg, W. \& Gall, M.D. (1983). Educatienal research: An intreduction. (ED. 4), New York: Longman Inc. Bayle, R.H. (1970). The bizarre history of American sport. In G.H. Sage. Sport and american society, 42-53. Readlng, Mass.: Addison-Wesley Publishing Company. 
Brubacher, J.S. \& Rudy, W. (1976). Higher educatien in

transition, (Ed.3), New York: Harper \& Row, Publishers. Burns, J.M. (1978). Leadership, New York: Harper \& Row, Publ lshers.

Capalle, R.G. (1979). Changina human systems, Toronto, Canada: International Human Systems Institute. Carlson, R.O. (1975). Environmental constraints and organlzational consequences: the public school and its cllents. In J.V. Baldridge and T. Deal. Managing change In the educational organizations, 187-200. Berkeley. Ca.: Mccutchan Publishing Corporation. Carnegle Foundation for the Advancement of Teaching (1982). The control of the campus, Washington, D.C.: Carnegie Foundation.

Christensen, S. (1979). Decision making and socialization.

In J.G. March \& J.P. Olsen. Amblouity and cheice in orqanizations. (ED,2), 351-385, Bergen, Norway: Universitetsfor laget.

Chu, D. (1982). The Amerlcan conception of hlgher education and the formal incorporation of intercollegiate sport. Quest, 34, 53-71.

Clark, B.R. (September 1965). Interorganizational patterns In education. Administrative science quarterly, 10 , $224-237$.

Cohen, M.D. \& March, J.G. (1974). Leadership and ambioulty: The american college president. New York: McGraw-Hill Book Company. 
Cohen, M.D. \& March, J.G. (1976). Leadership in an organized anarchy. In W.R. Lassey \& R.R. Fernandez. Leadershle and social change, (ED,2), 262-275. San Diego: University Associates.

Cohen, M.D. \& March, J.G. (1979). Decisions, presidents, and status. In J.G. March \& J.P. Olsen. Amblaulty and chaice in orqanizations, (ED,2) 174-203. Bergen, Norway: Universitetsfor laget.

Cohen, M.D. \& March, J.G. (1983). Leadership in an organized anarchy. In J.V. Baldrldge \& T. Deal. The dynamics of organlzational change in education. 333-365. Berkeley, Ca.: McCutchan Publ ishing Corporation.

Cohen, M.D., March, J.G. \& Olsen, J.P. (1972). A garbage can model of organizational cholce. Administratlve science quarterly, $17,1-25$.

Cohen, M.D., March, J.G., \& Olsen, J.P. (1979). People, problems, solutlons and the ambigulty of relevance. In J.G. March \& J.P. Olsen. Amblquity and choice in organlzatlons, (ED,2), 24-37. Bergen, Norway: Universi tetsfor laget.

Cozens, F. \& Stumpf, F. (1970). The role of the school in the sports life of America. In G.H. Sage. Sport and american soclety, 56-83, Reading. Mass, Addison-Wesley Publishing Company.

Danlels, A.S. (1969). The study of sport as an element of the culture. In J.W. Loy \& G.S. Kenyon. Sport, culture and society, 13-22. New York: Macmlllan \& Company. 
Edwards, H. (1976). Sport as a social institution. In A.Yiannakis, T.D. McIntyre, M.J. Melnick, D.P. Hart. Sport sociology: Contempory themes, 18-22. Dubuque, Iowa: Kendall/Hunt Publishing Company.

Erbach, G. (1969). The science of sport and sports soclology- questions related to development- problems of structure. In J.W. Loy \& G.S. Kenyon. Sport. culture and gociety, 23-36. New York: Macmillan \& Company.

Evan, W.M. (1971). The organization set: toward a theory of interorganizational relations. In J.D. Thompson. Approaches to orqanizational desian. 173-191. Pittsburgh: University of Pittsburgh.

Falla, J. (1981). NCAA, the volce of college sports: A dlamend anniversary history, 1906-1981. Mission, Kansas: NCAA

Farrell, C.S. (September 5, 1984). NCAA admits difficulty in catching violators of recruiting and financial-ald regulation. The chronicle of hioher education. 29-33.

Frederlckson, F.S. (1969). Sports and the cultures of man. In J.W. Loy \& G.S. Kenyon. Sport, culture and society. 87-100. New York: Macmillan.

Gall1co, P. (1970). Last stronghold of hypocrlsy. In G.H. Sage. Sport and american societye 111-120. Reading, Mass.: Addison-Wesley Publ ishing Company.

Glamatt I. A.B. (1981). The university and the public interest. New York: Atheneum. Glassman, R.B. (1973). Perslstence and loose coupling in 
11 ving systems. Behavloral sclence, $18,83-97$.

Goodhart, P. \& Chataway, C. (1968). War without weapons, London: W.H. Allen.

Goodman, Paul (1962). The community of schelars, New York: Random House, Inc.

Goodman, P.S. \& Kurke, L.B. (1982). Studies of change in organizations: a status report. In P.S. Goodman \& Assoclates. Change in organizations, 1-46. San Francisco: Jossey-Bass Publishers.

Gross, E. (1968a). University goals and academic power. Washington, D.C.: Offlce of Education.

Gross, E. (August $1968 \mathrm{~b}$ ). Universities as organizations: a research approach. Amerlcan soclological review, 33, 518-544.

Gross, E. \& Granbsch, P.V. (1974). Changes in university organlzation: 1964-1971. New York: McGraw-H111.

Gross, E. \& Grambsch, P.V. (1977). Power structures in universities and colleges. In G.L. Riley \& J.V. Baldridge. Governing academic organizations, 26-41. Berkeley, Ca.: McCutchan Publishing Corporation. Guetzkow, H. (1965). Communications in organizations. In J.G. March. Handbook of organlzatlons. 534-573. Chicago: Rand McNally.

Harrison, R. (1984). Leadership and strategy for a new age. In J.D. Adams. Transforming wark, 97-112. Al exander, Va.: Miles River Press.

Hart-Nibbrig, N. \& Cottingham, C. (1986). The Pelitical 
economy of college sports, Lexington, Mass.: Lexington Books, D.C. Heath and Company.

Hoffman, S. \& Stein, P. (1980). Sports and male role strain.

In D.F. Sabro, Jr. Jock: Sports and male identity.

82-97. Englewood Cliffs, N.J.: Prentlce-Hall, Inc.

House, R.J. \& RIzzo, J.R. (1972). Role conflict and ambigulty as critical variables in a model of organlzational behavior. Qraanizational behavior and human performance, 7, 467-505.

Jackson, J. \& Morgan, C. (1982). Organlzatlon theory: A macre perspect ive for management. (ED. 2), Engl ewood Cliffs, New Jersey: Prentice-Hall, Inc. Kamens, D.H. (1977). Legitimating myths and educational organizations: relationship between organizational ideology and formal structure. American soclological revlew, 42 , 208-219.

Kerr, D. (1972). The uses of the university: With a "postscrlpt-1972", Cambridge, Mass.: Harvard University Press.

Lawrence, P. \& Lorsch, J. (1967). Qrganlzation and environment, Boston: Division of Research, Harvard Business School.

Loy, Jr., J.W. (1972). Reaction to Luschen paper. In M.M. Hart. Sport in the socio-cultural process, 78-88. Dubuque, Iowa: Wm.C. Brown Company Publishers. Loy, Jr., J.W. \& Kenyon, G.S. (1969a). Sport, culture, and seciety, New York: Macmillan \& Company. 
Loy, Jr., J.W. \& Kenyon, G.S. $(1969 b)$. Toward a sociology of sport. In J.W. Loy \& G.S. Kenyon. Spert, culture, and seclety, 36-43. New York: Macmillan.

Luschen, G. (1972). Small group research and the group in sport. In M.M. Hart. Sport in the socie-cultural precess, 67-77. Dubuque, Iowa: Wm.C. Brown Company Publ ishers.

Lutz, F.W. (December, 1982). Tightening up loose coupling in organizations of higher education. Administrative sclence quarterly, 27, 653-669.

March, J.G. \& Olsen, J.P. (1979a). Organizational cholce under ambiguity. In J.G. March \& J.P. Olsen. Ambiouity and choice in organlzations, (ED,2) 10-23. Bergen, Norway: Un iversitetsfor laget.

March, J.G. \& Olsen, J.P. (1979b). Organizational learning and the ambiguity of the past. In J.G. March \& J.P. 01 sen. Amblauity and choice in organizations, (ED,2), 54-68. Bergen, Norway: Unlversitetsfor laget.

March, J.G. \& Olsen, J.P. (1979c). Attention and the ambiguity of self-interest. In J.H. March \& J.P. Olsen. Ambiouity and chelce in organizations (ED.2), 38-53. Bergen, Norway: Universitetsfor laget. March, J.G. \& Romelaer, P.J. (1979). Position and presence in the drift of decisions. In J.G. March \& J.P. Olsen. Amblouity and cholce in organizatlons, (ED,2), 251-176. Bergen, Norway: Unlversitetsforlaget. March, J.G. \& Simon, H.A. (1958). Organlaations, New York: 
John Wlley \& Sons, Inc.

Martinko, M.J. \& Gardner, W.L. (1984). The observation of high-performing educational managers: methodological issues and managerial Implicatlons. In J.G. Hunt, D.M. Hosking, C.A. Schneshelm \& R. Stewart (eds.). Leaders andmanagers, 142-162. New York: Pergamon. Mathews, Jr.,A.R. (1972). Student unrest and athletic dollars. In M.M.Hart. Sport in the socio-cultural precess, 418-422. Dubuque, Iowa: Wm.C. Brown Company Publ ishers.

McConnell, T.R. (1976). The function of leadership in academlc institutlons. In W.R. Lassey \& R.R. Fernandez (Eds.). Leadership and seclal change, 276-291. San Diego: University Associates, Inc. McCurdy, J. (April, 11, 1984). Students seek to divert boosters' money to academics. The chronicle of hlaher education. 28 , No. $7,33 \& 35$.

Merton, R.K., Fiske, M. \& Kendall, P.A. (1956). The Focused Interview: a report of the bureau of applied social research Columbia University, Glencoe, Ill inois: The Free Press.

Meyer, J.W. (1983a). Innovation and knowledge use in American public education. In J.W. Meyer \& W.R. Scott. Organizational environments: ritual and ratlonality. 233-260. Beverly Hills: Sage Publications, Inc. Meyer, J.W. (1983b). Centralization of funding and control in educational governance. In J.W. Meyer \& W.R. Scott. 
Organlzational environments: ritual and rationality. 179-197. Beverly Hills: Sage Publications, Inc.

Meyer, J.W. \& Rowan, B. (1978). The structure of educational organizations. In M.W. Meyer \& Assoclates. Environments and organizations: Theoretical and empirical

perspectives. 78-109. San Francisco: Jossey-Bass.

Meyer, J.W. \& Rowan, B. (1983). The structure of educational organizations. In J.W. Meyer \& W.R. Scott. Organizational environments: ritual and rationality. 71-97. Beverly Hills: Sage Publications, Inc.

Meyer, J.W., Scott, W.R. \& Deal, T.E. (1983). Institutional and technical sources of organizational structure: explaining the structure of educational organizations. In J.W. Meyer \& W.R. Scott. Organizatlonal environments: ritual and rationality. 45-67. Beverly H1lls: Sage Publications, Inc.

Mlllett, J.D. (1962). The academic communlty, New York: McGraw-H111.

Mooney, R.L. (1963). The problem of leadership in the university. Harvard educational review. 33, 42-57. Naison, M. (1980). Sports, women and the ldeology of domination. In D.F. Sabro, Jr. Jeck: Sports and male identity, 60-78. Englewood Cliffs, N.J.: Prentice-Hall, Inc.

National Collegiate Athletic Association (1985). 1985-86 Manual of the national collealate athletic association. 112-141. Mission, Kansas: National Collegiate Athletic 
Assoclation.

Nelson, L. \& Burns, F.L. (1984). Hlgh perfomance programing: a framework for transforming organizations. In J.D. Adam. Transforming werk: $A$ Collection of organization transformation readings, 226-242. Alexandria, Va.: Miles River Press.

Olsen, J.P. (1979). Cholce in an organized anarchy. In J.G. March \& J.P. Olsen. Amblouity and chelce in erganizations, (ED, 2), 82-139. Bergen, Norway: Universi tetsfor laget.

01 sen, J. (1979). University governance: non-participation as exclusion or choice. In J.G. March \& J.P. 0lsen. Ambioulty and cholce in organizations, (ED,22, 277-313. Bergen, Norway: Universitetsfor laget.

Ouchi, W.G. (1978). Coupled versus uncoupled control in organizational hlerarchles. In M.W. Meyer. Enviconments and organlaations, 264-289. San Franclsco: Jossey-Bass Publ ishers.

Padgett, J.F. (December, 1980). Managing garbage can hlerarchles. Adminlstrative science quarterly, 25 , 583-604.

Parsons, T. (1956). Suggestions for a sociological appraach to the theory of organlzations. Administrative science guarter ly, $1,63-85$.

Peters, T. \& Austin, N. (1985). A passion for excellence: The leadershle difference, New York: Random House. Peters, T.J. \& Waterman, Ir., R.H. (1982). In search of 
excellence: Lessons from amerlca's best-run companies. New York: Harper \& Row.

Pfeffer, J. (1978a). The mlcropolitics of organizations. In

M.W. Meyer \& Associates. Environments and

organizations: Theoretical and empirical perspectives, 29-50. San Francisco: Jossey-Bass.

Pfeffer, J. (1978b). The amblguity of leadership. In M.W. McCall,Jr. \& M.M. Lombardo. Leadershlp: Where else can we go?. 13-34. Durham, N.C.: Duke University Press.

Phlllips, J.C. \& Schafer, W.E. (1976). Subcultures in sporta conceptual and methodological approach. In $A$. Yiannakis, T.D. McIntyre, M.J. Melnick, \& D.P. Hart. Sport socioleay: Contemporary themes, 128-134. Dubuque, Iowa: Kendall/Hunt Publishing Company.

Riley, G.L. \& Baldridge, J.V. (1977). Governing academic organizations: New problems, new perspect lves,

Berkeley, Californla: McCutchan Publlshing Corporation. Rommetvelt, K. (1979). Decision making under changing norms. In J.G. March \& J.P. Olsen. Ambloulty and cheice in grganizations, (ED,2), 140-155. Bergen, Norway: Unl versitetsfor laget.

Ross, D.H. (1958). Adminlstration of adaptabllity. New York: Metropolitan School Study Council.

Rubin, I. (1983). Retrenchment, loose structure, and adaptability in the university. In J.V. Baldridge \& T. Deal. The dynamics of organlzational change in education. 191-208. Berkeley, Ca.: McCutchan Publishing Corporation. 
Sabro, Jr., D. (1980a). Jeck: Sports and male identity, Englewood Cl iffs, N.J.: Prentlce-Hall, Inc.

Sabro, Jr., D. (1980). Best years of my life. In D. Sabro, Ir. Jeck: Sports and male ldentity. 22-36. Engl ewood Cliffs, N.J.: Prentice-Hall, Inc.

Sage, G.H. (1970). Sport and Amerlcan soclety, Reading, Mass.: Addison-Wesley Publ ishing Company.

San Diego Union (June 5, 1984). Celleges, D-11.

Schein, E.H. (1985), orqanizational culture and leadership. San Francisco: Jossey-Bass Publ ishers.

Schuler, R.S. (October, 1977). Role conflict and ambiguity as a function of task-structure-technology interaction. Orqanlzational behavlor and human performance, 20 , 66-74.

Scott, J. (1971). The athletle revolution. New York: The Free Press.

Scott, W.R. (1981). Organizations: rational, natural and open systems, Engl ewood Cliffs, N.J.: Prentice-Hall. Scott, W.R. (1983). The organization of environments: network, cultural, and historical elements. In J.W. Meyer \& W.R. Scott. Organizational environments: ritual and rationality, 155-175. Beverly Hills: Sage Publ lcations, Inc.

Scott, W.R. \& Meyer, J.W. (1983). The organlzation of socletal sectors. In J.W. Meyer \& W.R. Scott. Qrganizational environments: ritual and rationality. 129-153. Beverly Hills: Sage Publications. 
Selznlck, P. (1957). Leadership in administration. New York: Harper and Row.

Serglovanni, T.J. (1984). Cultural and competing perspectives in administrative theory and practice. In T.J. Serglovanni \& J.E. Corbally. Leadership and organizational culture: New perspectives on administrative theory and practice, 1-11. Urbana, Illinois: University of Illinols Press.

Simon, J.L. (1969). Basle research methods in social science: The art of empirical investlation. New York: Random House.

Smith, S. (July, 1, 1984). NCAA reels under barrage from the courts. San Diego Union. $\mathrm{H} 1, \mathrm{H} 3$.

Snyder, E.E. \& Spreitzer, E. (1976). Sociology of sport: an overvlew. In A. Ylannakis, T.D. McIntyre, M.J. Melnick, D.P. Hart. Sport soclology: Contemporary themes, 1-11. Dubuque, Iowa: Kendall/Hunt Publishing Company. Sproul, L., Welner, S. \& Wolf, D. (1978). Organizing an anarchy: Bellet, bureaucracy, and polltics in the national institute of education. Chicago: University of Chicago Press.

Stake, R.E. (February, 1978). The case study method in social inquiry. Educational researcher. 7, 5-8.

Stake, R.E. (1983). The case study method in social inquiry. In G.F. Madaus, M.S. Scriven, \& D.L. Stufflebeam. Evaluation models: Vlewpoints on educational and human services evaluatlon, 279-286. Boston: Kluwer-Nijhoff 
Publishing.

Stern, R.N. (June 1979). The development of an interorganizational control network: the case of intercolleglate athletics. Administrative sclence quarterly, 24, 242-266.

Stern, R.N. (March 1981). Competitive influences on the interorganizational regulation of college athletics. Administrative science quarterlye 15-32.

Stogdill, R.M. (1971). Dimensions of organizational theory. In J.D. Thompson. Approaches to oraanizational desian. 2-56. Pittsburgh: University of Pittsburgh.

Torbert, W.R. (1981). Why educational research has been so uneducational: the case for a new model of social science based on collaborative inquiry. In P. Reason \& J. Rowan. Human inquiry: A sourcebook of new paradiom cegearch, 141-152. New York: John Wiley \& Sons. Valll, P.B. (1978). Toward a behavioral description of hlgh-performing systems. In M.W. McCall, Jr. \& M.M. Lombardo (eds.). Leadership: Where else can we go?, 104-125. Durham, N.C.: Duke University Press.

Vall1, P.B. (1982). The purposing fo high-performance systems. Organizational dynamics, Autumn, 23-39.

Vaill, P.B. (1984). The purposing of high-performance systems. In T.J. Sergiovanni \& J.E. Corbally (Eds.). Leadership and organization culture: New perspectives in administrative theocy and practice, 85-104. Chicago: Unlversity of Illinois Press. 
Vance, N.S. (March 28, 1984). TV football past is a cooperative venture, not monopolistic, NCAA tells high court. The chronicle of higher education. 28 , No. 5 , 27-28.

Vance, N.S. (May 16, 1984). Sport is a religion in America, controversial professor argues. The chronicle of higher education. 28 , No. $12,25-26$.

Vance, N.S. (September 5, 1984). San Diego State's beleaguered sports program: football losses, NCAA penalties, big deficits. The chronlcle of hiaher education, 29 , No, 2,30 .

Welck, K.E. (1974). Middle range theories of social systems. Behavlor science, 19, $357-367$.

Welck, K.E. (March, 1976). Educational organizations as loosely coupled systems. Administrative science quarterly, $21,357-367$.

Welck, K.E. (1977a). Organization design: Organizations as self-designing systems, Organizational Dynamics, 6 , 30-46.

Welck, K.E. (1977b). Re-punctuating the problem. In P.S. Goodman \& J.M. Pennings. New perspectives on organizational effectivenegs, 193-225. San Francisco: Jossey-Bass.

Weick, K.E. (1978). The spines of leaders. In M.W. McCall, Ir. \& M.M. Lombardo. Leadershlp: Where else can we go?, 37-61. Durham, N.C.: Duke University Press.

We ick, K.E. (1979). The social psycholegy of 
organlzing.(ED,2), Reading, Mass.: Addison-Wesley Publishing Company.

Welck, K.E. (1982a). Administrating education in loosely coupled schools. Phi delta kappan. June, 673-676.

Welck, K.E. (1982b). Management of organizatlonal change among loosely coupled elements. In P.S. Goodman and Assoclates. Change in organizations: New perspectives on theory, research, and practice, San Francisco: Jossey-Bass Publishers.

Welck, K.E. (1983). Educatlonal organizations as loosely coupled systems. In J.V. Baldridge \& T. Deal. The dynamics of organizational change in education. 15-37. Berkeley, Ca.: McCutchan Publishing Corporation.

Weiner, S.S. (1979). Particlpation, deadlines, and cholce. In J.G. March \& J.P. Olsen. Ambloulty and choice in orqanlzatlons. (ED.2), 225-250. Bergen, Norway: Unlversi tetsfor laget.

Wolf, D. (1972). The growing crisis in college sports. In M.M. Hart. Sport in the socio-cultural process, 445-472. Dubuque, Iowa: Wm.C. Brown Company. Yin, R.K. (1984). Case study research: Desian and methods, Beverly Hills, Ca.: Sage Publications. Yinger, J.M. (October, 1960). Contraculture and subculture. American socialogical review, 25, 625-635. 
APPENDIX A

Reproduced with permission of the copyright owner. Further reproduction prohibited without permission. 


\section{INTERVIEW QUESTIONS}

Background: How long have you been at the University?

1. How would you compare the performance of your athletic department (or team) with other Division III departments (or teams)?

2. What has been the departments (or teams) performance in N.C.A.A. regional or national competition?

3A. How would you compare the athletic department (or your team) now to where it was when you first arrived UCSD? B. Do you feel that there has been an improvement, a leveling off, or a decrease in development?

4. Has the athletic department (or your team) ever been judged by others to be better than other Division III departments (or teams)?

$5 A$. What is the budget for the athletic department cor your team)?

B. Based on your knowledge do you feel that it's above average, average, or below average in relationship to other Division II athletic departments (or teams)?

6A. As a department is there for As a coach is there or Dees your caach make) a concentrated effort to recrult talented athletes?

B. Based on your knowledge do you feel that the talent represented by the student/athletes in the athletic department (or on your team) is above average, average, or below average in relationship to other Division III departments (or teams)?

7. How would you compare the athletic facilities at U.C.S.D. with other Division III institutions: above average, average, or below average?

8. In competing against other Division III teams, do you feel that U.C.S.D.'s athletlc team's uniforms, equipment and travel schedules are above average, average, or below average in comparison to these teams?

9A. How do you feel other institutions for coaches or teams) view U.C.S.D.'s athletic department (or specific team)?

B. Based on your experience has the U.C.S.D. athletic program influenced any other institution's athletic program in any way? 
10A. Conslderling the athletic department is a part of the total unlversity environment, how would you say the department reflects the ideas of culture of this university? B. What would you think others outside of the athletic department would say condernlng how the department reflects the ideas of the culture of UCSD? c. Would you say the athletlic department better reflects its own culture rather than the university as a whole?

11A. What would you say are the broad purposes of the athletic department of U.C.S.D.?

B. What objectives do you see as important to

fulfilling these purposes?

12A. Do you feel that the UCSD athletic team coaches (or you as a coach or youk coach) give extra effort beyond what is expected of them (or you or him/her)?

B. How committed do you feel the coaches are (or you are) to your previously stated broad purposes and objectives of the athletic department?

C. How would you describe the motivation of the coaches? (coaches only: How motivated are you?)

13A. What do you perceive the task of the athletic department to be?

B. Do you feel that all members of the department are committed to this task?

C. Do you feel that the indlvidual above you cor individuals below yous in the hierarchy are committed to this task? Are you committed to the task of the athletic department?

$D$. Have any new or innovative methods been introducted within the athletic department (or your team or the specific team) since you have been involved in the athletic program?

Omit Question \#14 for team members:

$14 \mathrm{~A}$. How often do you meet with your direct supervlsor (or the individual whose responsibilities include the ashletis department ??

B. How much autonomy do you have in you position?... Are you often reviewed?

C. As a department (or ceach), do you have any interactions with other departments within the university-either through formal or informal contacts? D. Do the coaches (or you) have other academic responsibilities besldes coaching?

E. If so, who decides these academic responsibllities? 
15A. How would you describe how the rest of the unlversity percelves the athletic department?

B. Would you say the athletic department represents a typlcal or atypical unlversity department as you perceive it?

C. In what way?

D. NOTE: only ask if the person considers the department to be atyplcal: Would you say that the department is consldered a problem by other departments in the university because of this atypical nature?

16. Would you like to add anything to the answers you that you already have given? 
APPENDIX B

Reproduced with permission of the copyright owner. Further reproduction prohibited without permission. 


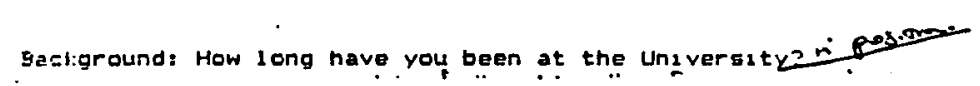

ancent. How would you compare the periormance of yeur ethlet:

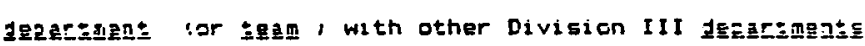
for imege i

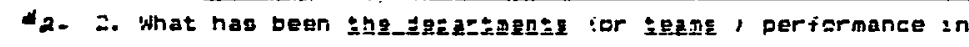
N.C.A.A. regional or national competitian:-

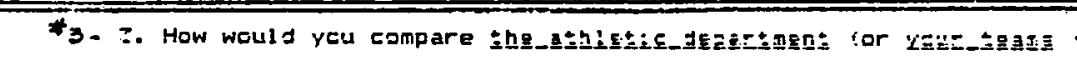

now to where it was when you firet arraves U.C.S.D."

Do you ieel that there has been an imerovemen:. I
leveling off, or a decrease in develooment:-

Do you ieel that there has been an imerovemen:. I
leveling off, or a decrease in develooment:-

$\mid$\begin{tabular}{||l|l|}
\hline \\
\hline
\end{tabular}

(




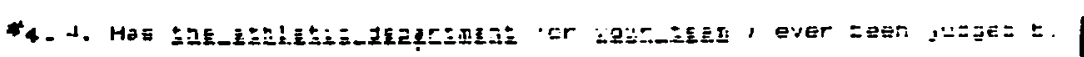

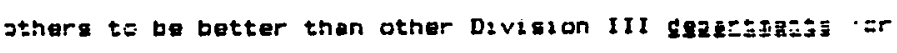
anege i?

Baced on your knowledge do you feel that at's abs's

overage, everage, or below avarage in rolatienshif to

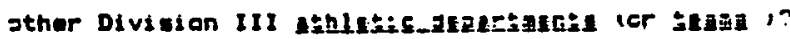

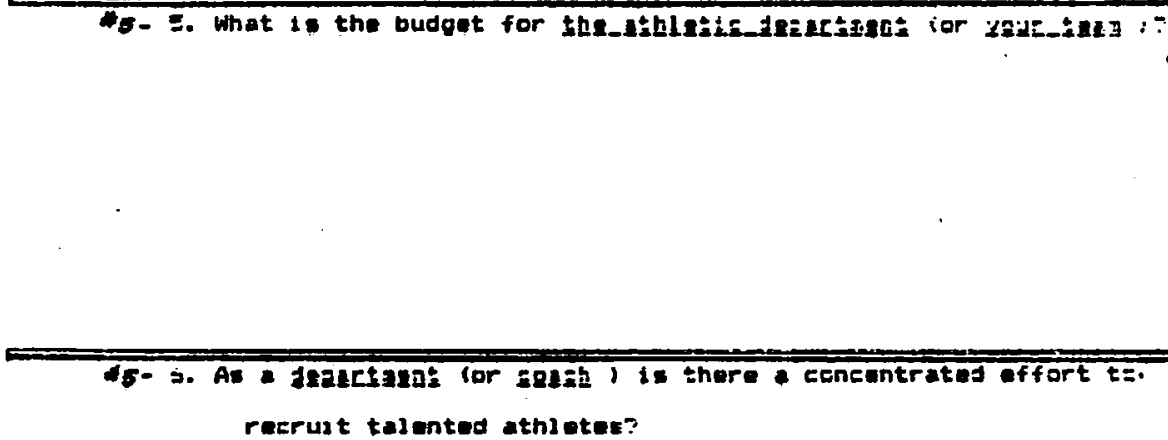

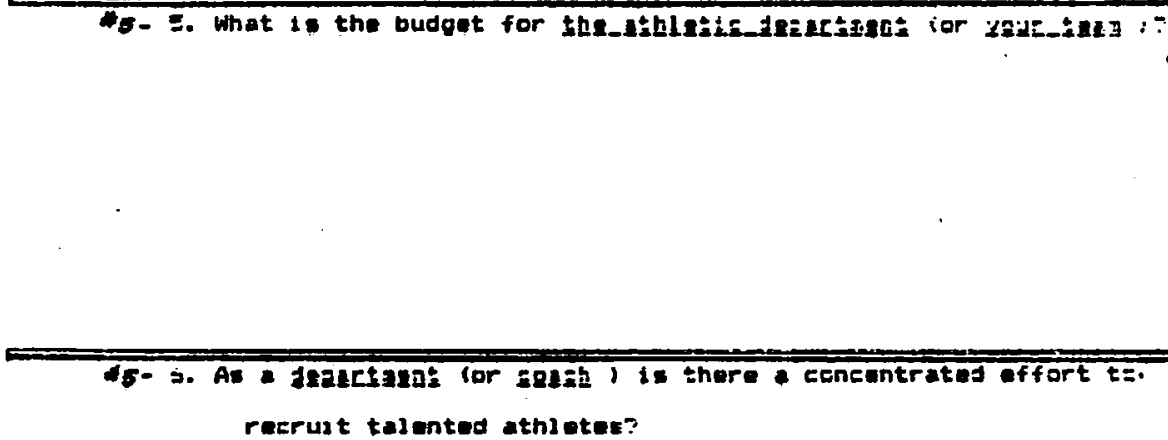

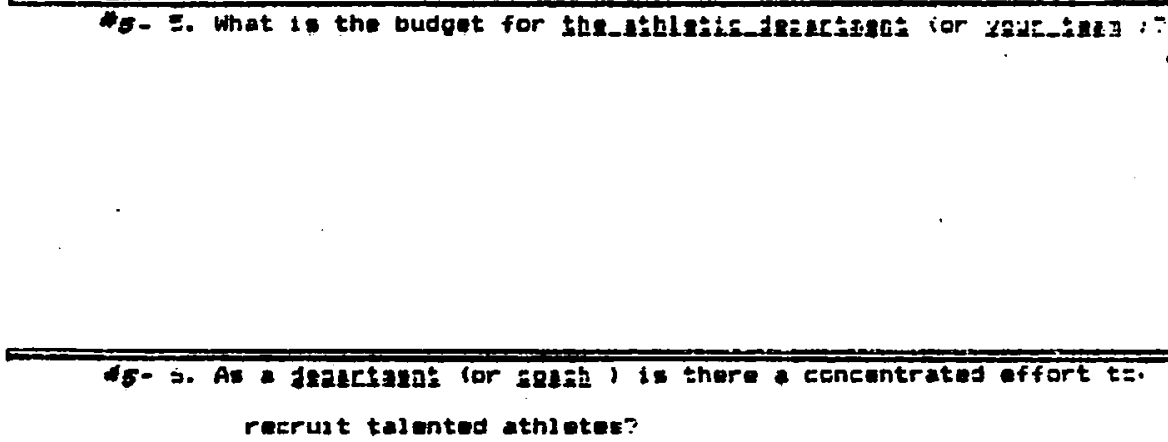

.

-

$\cdot$

.

Based on your knowledge do you feel that the telent

represented by the etudent/athletes 10_the_nshlgi:

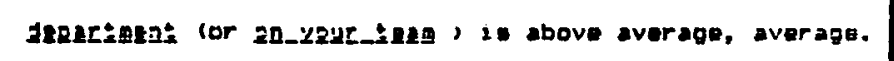

or balow average in relationship to othar Divigiar. 11:

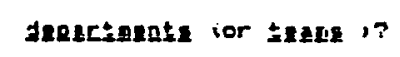


6 - 7. How would you compare the athletic faczlzties at U.C.S.D. Wztr. other Division III institutionas above avaragu, average, or below avarage?

to e. In competing against other Diviuion III teems, do you feel that U.C.8.D.' athletic tean's uniforms, equipeant and trave? echadulas are above average, averaga, or below average in comparison to these teame?

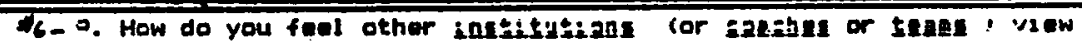

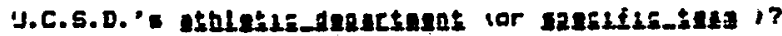

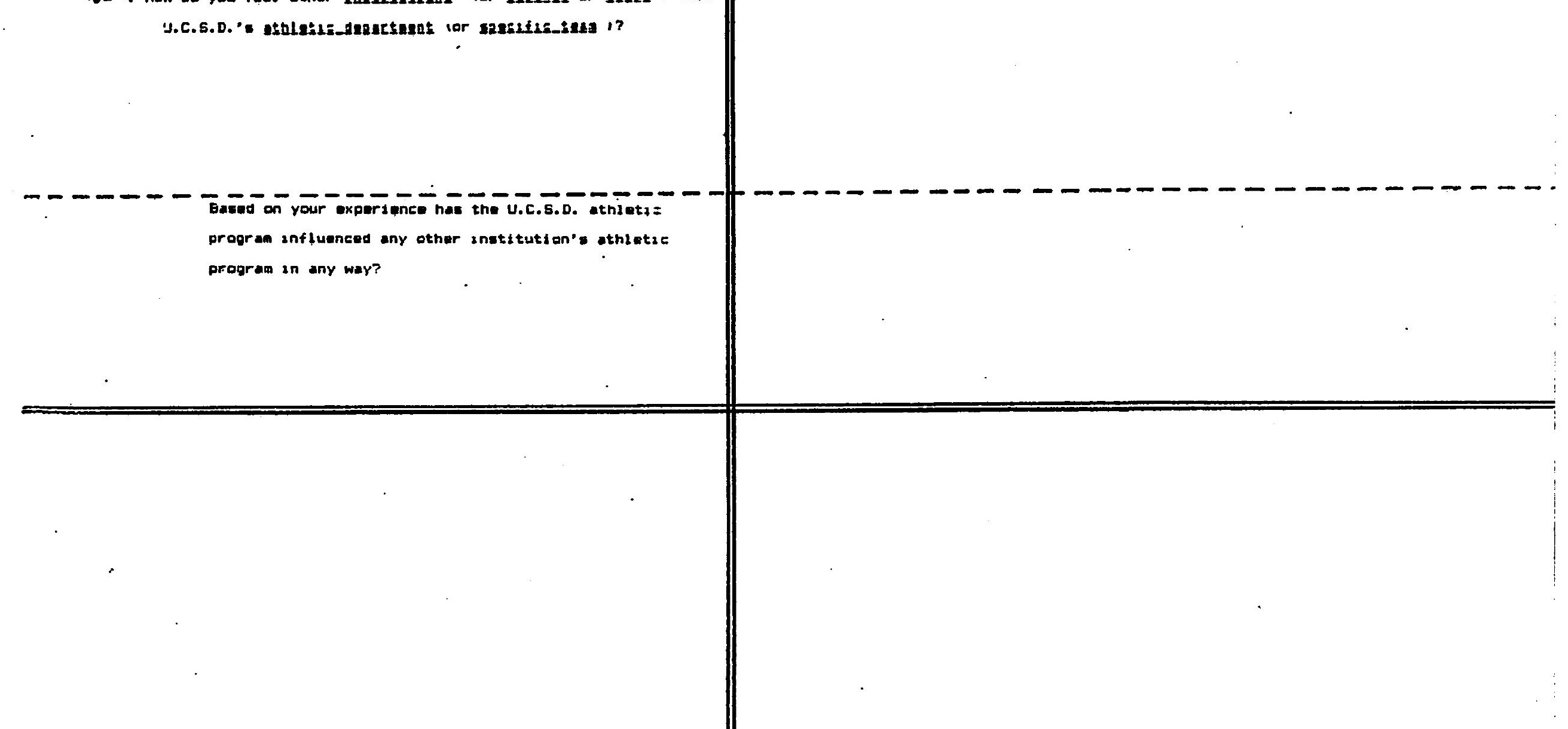




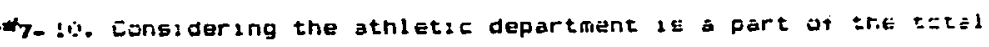
university envaronment, how would you say the departmen: ! reflects the ideas of culture of this university?

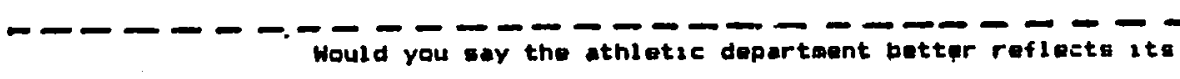
own culture rather than the university as a whole?

42 - 11. What would you say are the broad purposes of tha athletie department of U.C.E.D.:

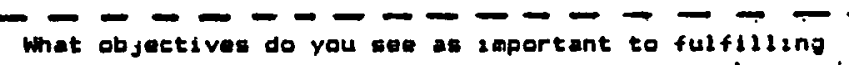
thase purpasen? 


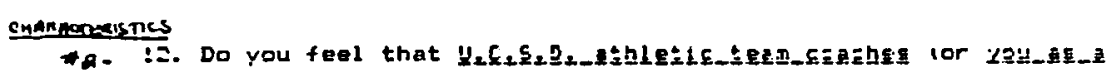
igenh, give axtro offort bevond what is aipected of these? Yax i?

How committed do you ferl the_esenes ior ygu_acs, te your previously stated broad purpotes and ob goctives of the athletic dopartmont?

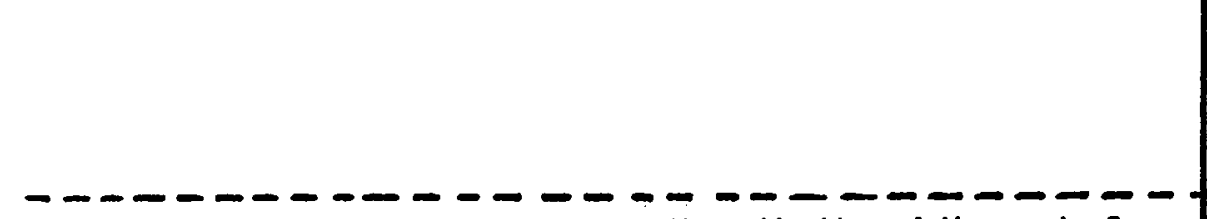
How would you descrios the motivation of the coacher? coaches onlys How motivated are you?!

43 13. What do you porceive the task of the athletic department te be? Do you feel that all mambors of the department ar: comaltied to this task?

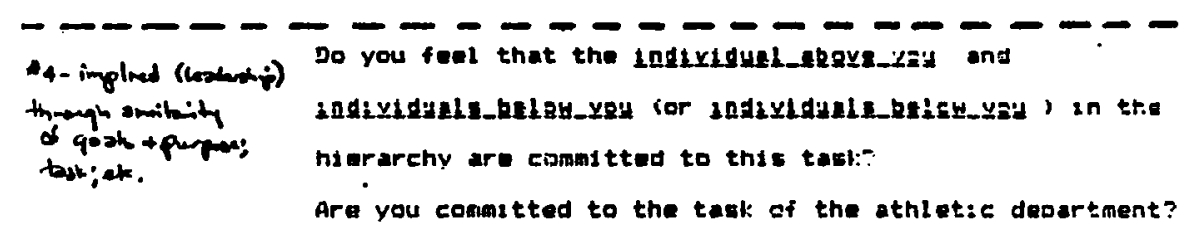

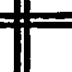

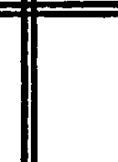

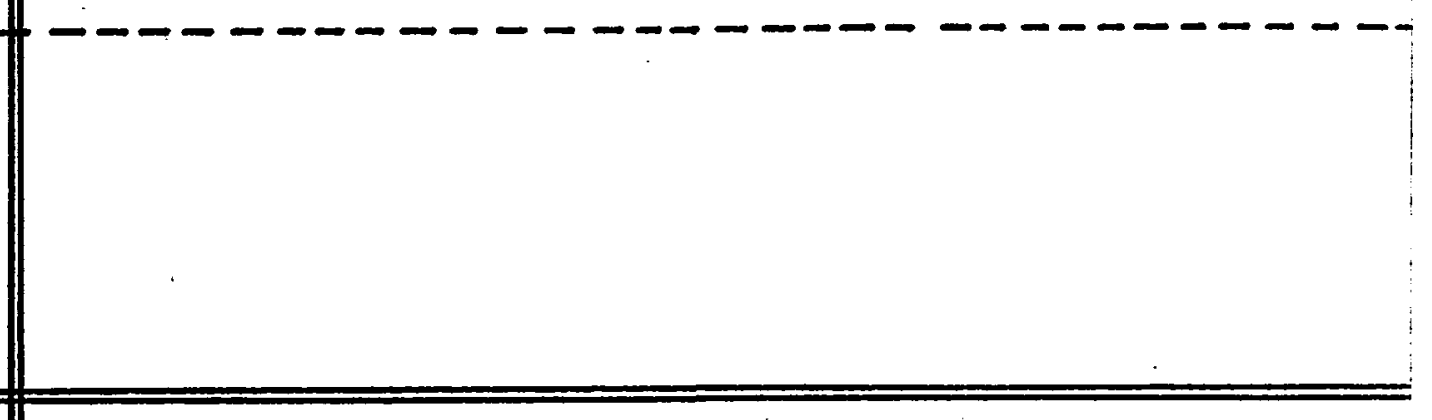




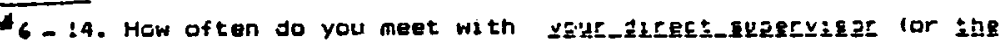

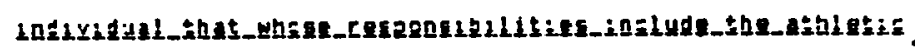
1ezertagn: is comit the following questzons for the chancellor and tean memberk."

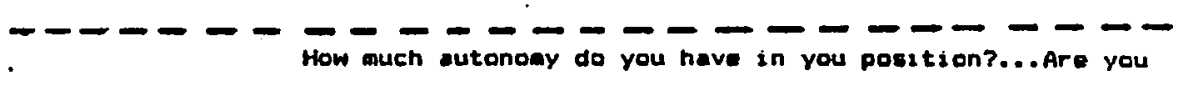
often raviawed?

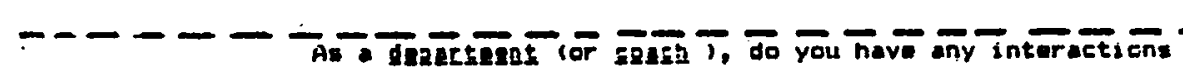
with other departements within the unz versity- esther through formal or informal contects?

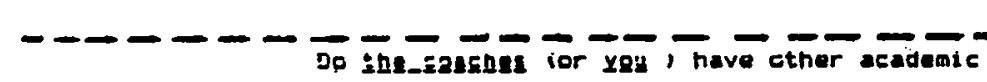

responsibilities basides caaching?

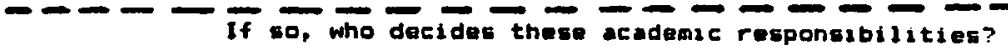




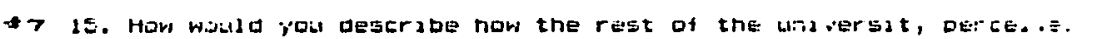

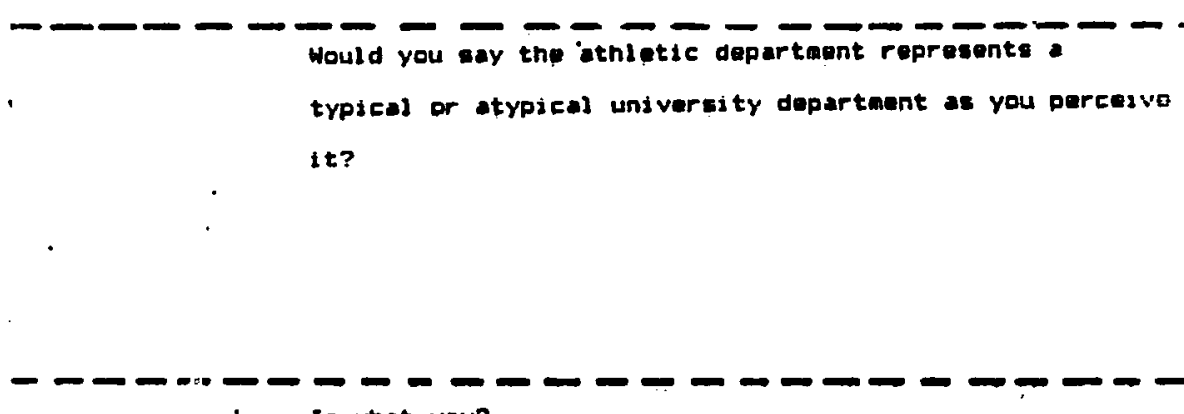
al ready have given? 
APPENDIX C

Reproduced with permission of the copyright owner. Further reproduction prohibited without permission. 


\section{UNIVERSITY OF CALIFORNIA, SAN DIEGO \\ N.C.A.A. Athletic Record: 1981-1985 \\ Division III}

WOMEN'S VOLLEYBALL:

1981- N.C.A.A. National Champlons

1982- N.C.A.A. Champlonshlp Tournament: 2nd Place

1983- N.C.A.A. Champlonshlp Tournament: 2nd Place

1984- N.C.A.A. National Champions

1985- N.C.A.A. Reglonal Tournament: Final Elght

WOMEN'S TENNIS:

1982- N.C.A.A. Champlonship Tournament: 2nd Place 1984- N.C.A.A. Championship Tournament: 2nd Place 1985- N.C.A.A. National Champlons

MEN'S TENNIS:

1982- N.C.A.A. Championship Tournament: 3rd Place

MEN'S GOLF :

1985- N.C.A.A. Championshlp Tournament: 2nd Place

MEN'S SWIMMING:

1984- N.C.A.A. Championship Tournament: Brd Place 1985- N.C.A.A. Champlonship Tournament: Brd Place

WOMEN'S SWIMMING:

1985- N.C.A.A. Championship Tournament: 3rd Place

1984-85: 12 teams quallfied for N.C.A.A. regional or

national champlonship tournaments; 5 teams in top

three nationally

Last 4 Years: average 33 All-Americans per year; 3 women volleyball players named national athlete of the year-1985, 1984,1983

Academlc: 40 percent of all athletes achleved a 3.0 GPA or better; three student/athletes of the graduating cluss of 1985 were among 5 graduating seniors to be selected for the academic and extracurricular contributions award. 
APPENDIX D 


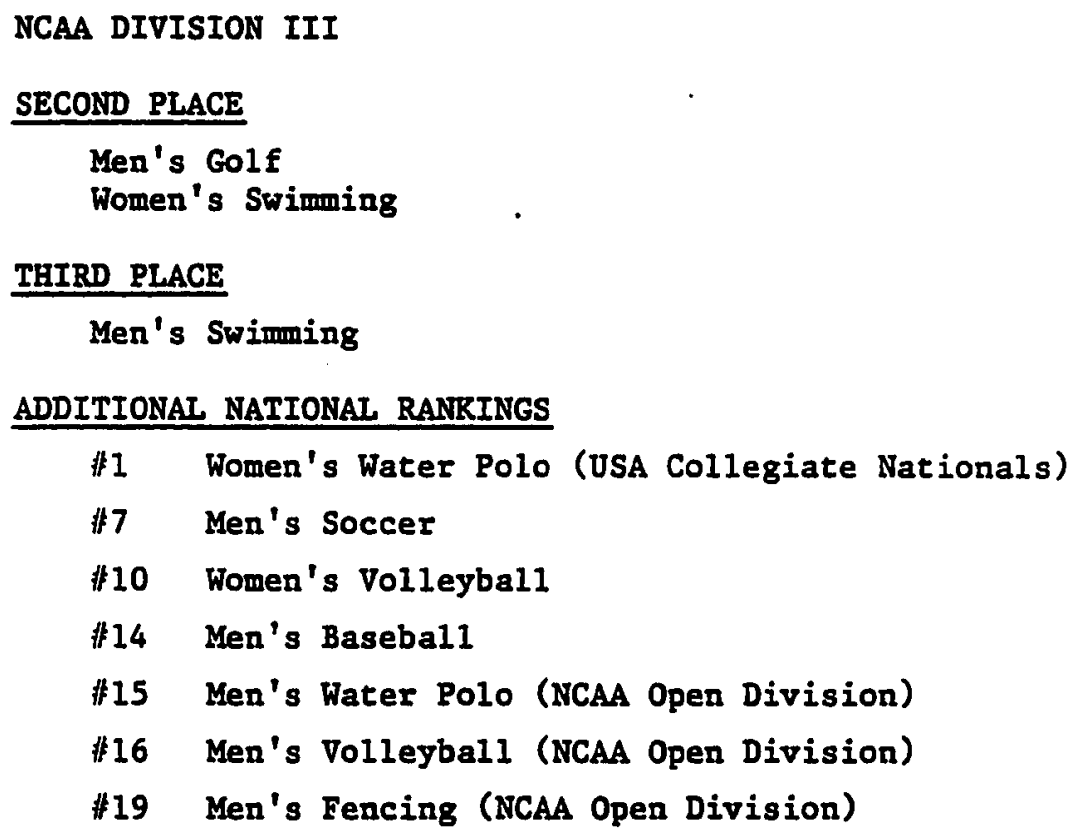

Individual National Champions....................... 12

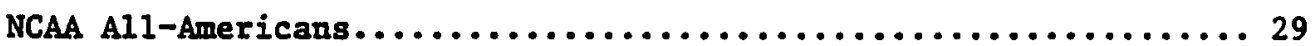

Other Al1-Americans............................... 4

Individual Qualifyers for NCAA Post Season Championships........107

Teams with Athletes in NCAA Championships................. 11

$\begin{array}{ll}\begin{array}{l}\text { Roger Brisbane } \\ \text { Men's Swimming }\end{array} & 100 \& 200 \text { Yard Butterf1y \& } 400 \text { Yard Medley Relay } \\ \begin{array}{l}\text { Butch Cramer } \\ \text { Men's Swimming }\end{array} & 400 \text { Yard Medley Relay } \\ \begin{array}{l}\text { Derron Fredrick } \\ \text { Men's Swimming }\end{array} & 400 \text { Yard Medley Relay } \\ \begin{array}{l}\text { Bill Razmierowicz } \\ \text { Men's Swimming }\end{array} & 200 \text { Individual Medley, } 1650 \text { Freestyle \& } 400 \text { Medley Relay } \\ \begin{array}{l}\text { Tracy Mulvany } \\ \text { Women's Swimming }\end{array} & 500 \text { Yard Freestyle \& } 1650 \text { Yard Freestyle } \\ \begin{array}{l}\text { Jeff Stabile } \\ \text { Men's Diving }\end{array} & \text { One \& Three-Meter Diving }\end{array}$


MEIN'S BASEBaLI _ RANKRD 14TH

Head Coach: Lyle Yates

Won: 22 Lost: 19 Tied: 2

Second Place at West Regional

Team MVP: Bob Natal

LIEN'S BASKKETBAIT

Head Coach: Tom Marshall

Won: 14 Lost: 12

Team MVP: Greg Ramansky

FOMBN'S BASTETBALI

Head Coach: Judy Malone

Won: 11 Lost: 14

Team MVP: Shanda Elzy \& Beidi Jingling

MENN'S CRETr

Head Coach: Jon Lawson

WOMIRR'S CREW

Head Coach: Jack Vallerga

MER's CROSS COUNIRY -

Head Coach: Andy Skief

Third at West Regional

Team MVP: Chris Thomas

WOLEN'S CROSS COUNIRT-

Head Coach: Andy Skief

Third at West Regional

Team MVP: Sabrina Jensen

MER'S FENCTHO-19TH II XCAA

Head Coach: Lynne Antonelli

Won: 15 Lost: 1

West Regional Champs - Epee

Team MVP: Mark Christe

WOLEN'S FERCING-

Bead Coach: Lynne Antonelli

Won: 8 Lost: 8

Team MVP: Leslie Richter

COBD GOLF_-2ND IN XCAA

Head Coach: Mike Wydra

Won: 13 Lost: 5

Team MVP: Pat Weishan

MEN'S SOCCER RAKKED 7TH

Head Coach: Derek Armstrong

Won: 23 Lost: 3

West Regional Champions

WOAIEN'S SOCCER-

Head Coach: John Leaney

Won: 9 Lost: 10 Tied: 2

Team MVP: Adriene Clark
WOMEN'S SORTBALI-_

Bead Coach: Colleen Wight

Won: 29 Lost: 13

So. Cal. Softball Conf. Champion

Team MVP: Patty Campbell

LEN'S SWTMING \& DIVING -3RD IN NCAA

Head Coach: Bill Morgan

Won: 4 Lost: 4

Team MVP: Bill Kazmierowicz

WOMEN'S SWTMETri \& DIVING-2ND IN NCAA

Head Coach: Bill Morgan

Won: 9 Lost: 1

Team MVP: Tracy Mulvany

LEN'S TENIIS

Head Coach: Jim Schanback

Won: 11 Lost: 12

Team MVP: John Mapes

WOMRN'S TEREIS

Head Coach: Liz LaPlante

Won: 9 Lost: 9

Team MVP: Jessica Vernon

LEN'S TRACK \& FIBLD

Head Coach: Andy Skief

Team MVP : Henry, Joe, John Garon

WOAm 'S TRACR \& FIETD

Head Coach: Andy Skief

Team MVP: Gisele English

LEN'S VOLLETBALI R RANKBD 16TH

Head Coach: Digger Graybill

Won: 14 Lost: II

Team MVP: Eric Hallman

WOMBax's VOLLEYBall R RAITED 10TH

Head Coach: Doug Dannev IK

Won: 26 Lost: 19

Team MVP: Christy Wada

IER'S WATER POLO-RANKED 15TH Head Coach: Denny Harper

Won: 19 Lost: 15

Team MVP: Duncan Millar

WOMEN'S WATER POLO OSA NAT'L CBAMPS

Head Coach: Denny Harper

Won: 19 Lost: 4

Team MVP: "The Team" 


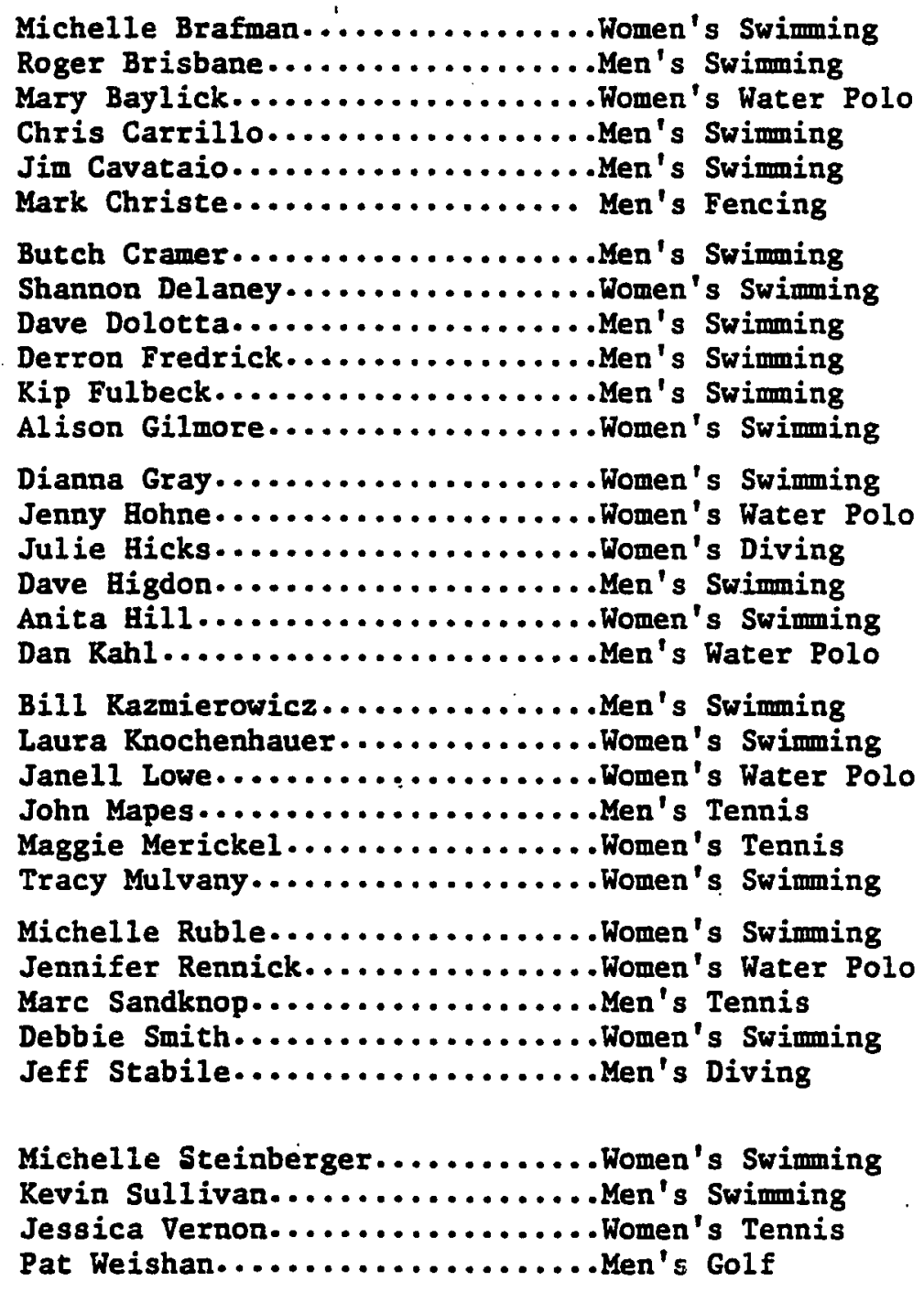

FOUR-YBAR ALI-AMBRICANS

\author{
Butch. Cramer \\ Alison Gilmore

\begin{abstract}
Men's Swimming
Women's Swimming
\end{abstract}

THREE-YRAR ATL-AYBRICANS

Michelle Brafman
Dave Higdon
Bill Kazmierowicz
Jessica Vernon
Pat Weishan

Women's Swimming
Men's Swimming
Men's Swimming
Women's Tennis
Men's Golf

THO-MEAR ALT-ALERICAIS

Kip Fulbeck

Bill Razmierowicz

Laura Knochenhauer Duncan Millar

Irene Mons

Tracy Mulvany
Men's Swimming Men's Water Polo Women's Swimming Men's Water Polo Women's Swimming Women's Swimming 
APPENDIX E 

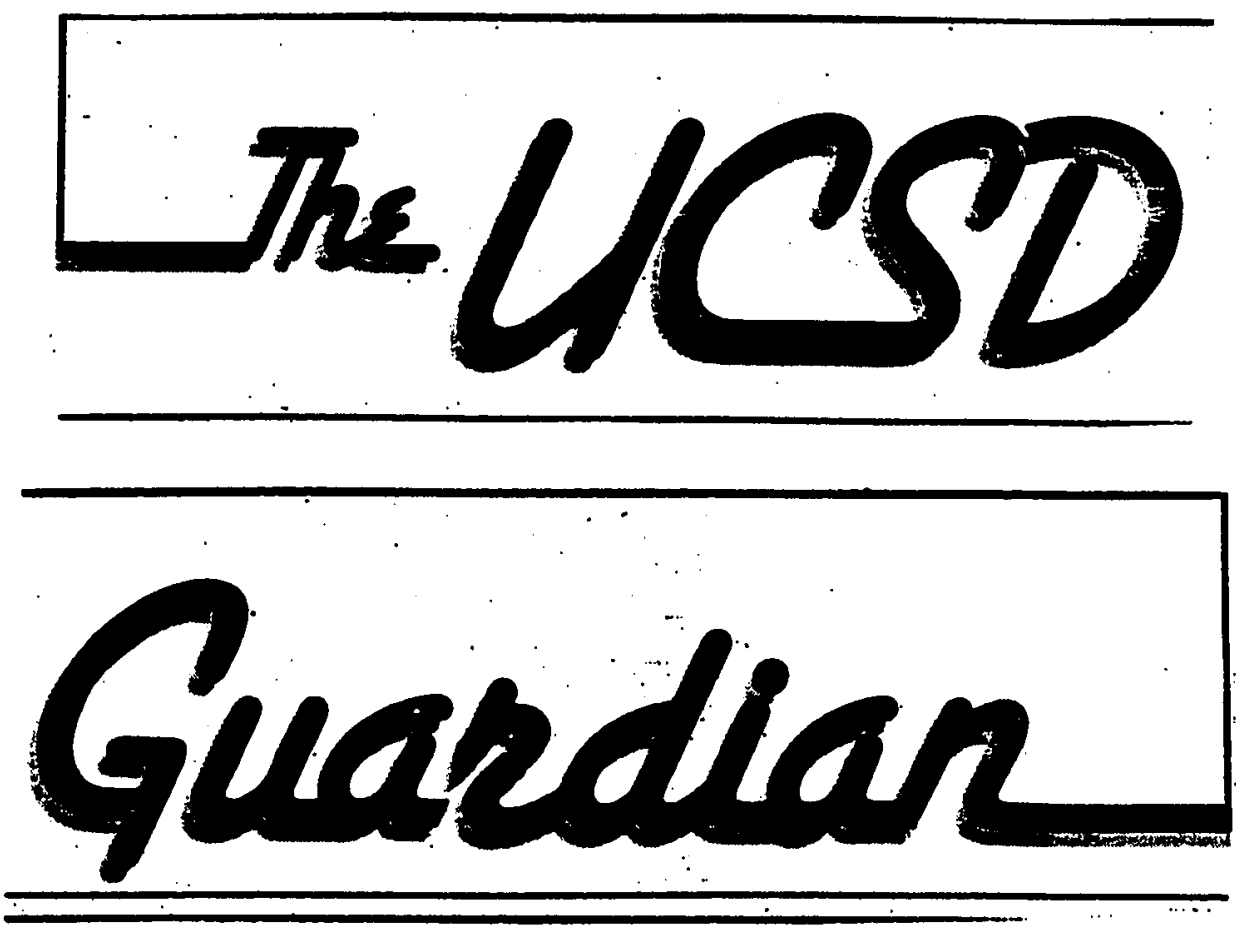

\section{UNIVERSITY OF CALIFORNIA, SAN DIEGO MONDAY, MARCH 10, 1986 VOLUME 57, \#19}

\section{Divisional Dilemmas}

BY JOHN SCHACHT, GUS SANTOYO \& MATT LAIT

$\mathrm{W}$

HEN BARRY CUNNINGHAM first came to UCSD as an assistant baskebball coach in 1967 , the athletic porential had Cunningham salivating. Being a part of a thriving community, a growing institurion, as well as a member of the prestigious UC educational system. intercollegiate athletics at UCSD would inevitably be a vital part of college life for the athletes and student body. But after nineteen years of involvement with UCSD, many as the head basketball coach, Cunningham can only sit and wonder.

Please tum to page 12 


\section{Continued from.page 1}

"The hardest part of my job of being an athletic coach was to look at this campus and see what it could be athletically and what it is - between the dream when I was first hired and the realify. That was the most difficult part of being an achletic coach at UCSD."

Cunningham's disappoinement stems from the university's conseivative approach to intercollegiate athletics. The philosophy of the athletic program; according to a $1986-87$ budget request, has been "to: allow the maximum number of students to enjoy the challenges and exhilimation of healthy athletic competition." UCSD, in adherence to this policy, has been one of the most successful athletic progiams in NCAA Division III, including the wirningest women's program in the nation. There are more sports available $w$ the students at UCSD than in any other school in the UC system with over 700 athletes competing in over 28 sports.

Yet this rosy side has a llip side that does not hide some other real problems facing the athletic department the lack of funds for facilities, equipment, and coaches salaries; scheduling conflicts - competing against schools including some roughty 50 times smaller, independent status with unlikely playoff aspirations; and competing against scholarship programs.

Add to these difficulties the phenomenal growth of the UCSD student population, whict is projected io be approximately. 20,000 in the year 2000 , and it

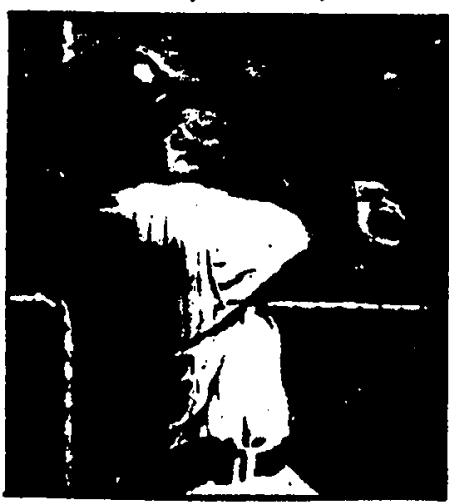

UC stars in non-Conference sports, like baseball's Bob Natal (above), cannoc receive all-league accolades. may become increasingly difficult to maintain this Division III philosophy. In this two-part investigative report, we examine some of the problems that have plagued UCSD Achiletics.

Item: UCSD is the largest. Division III school in the nation, seven and a half times langer than any of its competition. - Registration fee incem Katy Haberkem. -What are you (UCSD) doing in Division III? With a school this big you ought to be cleaning up in pivision III." - Former NBA star and Notre Dame AllAmerican John Shumate; Coach of Grand Canyon College and winner of UCSD's La'Jolla Classic Basketbal Toumament.

- You guys (UCSD) shouldn't be Division III, you are too big." Athletic director at UC Davis.

-Other schools "have no business telling. us what Division we should be in." Mike Hipp. assistant athletic director.

-I don't think our size is unfair. We're totally in compliance with Division II NCAA philosophy. Pomona-Pítzer has a budger wrice of what is ours. Isn't that unfair?" -Judith Sweet, UCSD Achletic Director.

- Pomona Pizer, with an enrollment of about 1500 raises more funds than a school of 14,000 .

-Orie of my greatest thrills this year was beating $a$ school the size of UCSD." - Daivid Appleby, baskemall player at Christ

College. Christ College's undergraduate enrollment is 250. - Three years ago the NCAA defeated a proposal that sought. to pur an attendance ceiling of 5-6,00 students for Division III schools.

-UCA, Division I; UC Berkeley Divison l; UC Sania Bartara, Division I; UC Irvine, Division I; UC Davis, Division II; UC. Riverside, Division II. Only UC Sanea Cruz - with an enrollment of 7,000 - and UCSD are.Division III.

Ilem: UCSD competes as an Independent rather than competing in a conference. Some UCSD teams compete against Division I and II schools in open divisions.

-Add Marshall: "It's tantamount that we get into a conference even if the cost will be more."

- When a team is not in a conference, every game on the schedule counts for possible tournament play, whereas if a team is in a conference only league games matter.

"When we lost on December 17. I might as well have stopped playing right then; technically. We had nothing more to play for. It can't be that way. Whittier and Pomona-Pizer (reams in the SCIAC conference) can lose all their games uniil January 17 , and it doesn't mawer. They have only eight league games that count for playoffs. We have 24." Marshall

- The only teams that can compete as an Independent are in Division I and nationally known like DePaul, Notre Dame, Dayton and Marquette." -UCSD. Basketball Coach Tom Marshall.

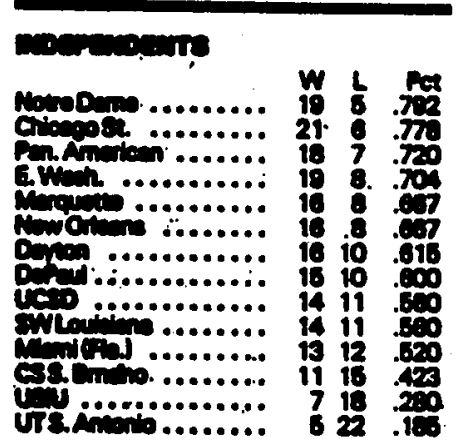

LA. Times Standings

- Because the baseball team was no in a conference last year, they felt they were robbed of a playoff bid.

- Because we are a big school they are holding that against us. but that's nor fair to my ballplayers. They didn't choose to be an independent, or be in Division III - theyre the ones being dealt a bad hand." - Lyle Yates, UCSD Baseball coach, May of 1985.

- Three years ago we decided to move our of the NALA Division. because we thought it was unfair to compete against scholarship schools." - Sweet.

-Teams like the water polo and : men's volleybal have to compete. in an Open Division. In an Open Division, UCSD's Division III teams compete against Division I and II schools who can give scholarships for the same national championships. - Every year, we knock off sone of the top teams in the nation but it's tough to compete against what I call.the 'professional programs' like (Division I 
scholarship schools) Pepperdine and Stanford." - Water polo coach Denny. Harper.

- Sweet agrees that getting UCSD into a conference is important, however, she feels the process may be slow. "We are discussing the possibilities of a conference right now. We want to develop our relationships with other Division III instinutions that have academic standands similar to ours. Such AAU schools as MIT. University of Chicago, RIT, Case Westem and Emory Universicy are some of the top 50 research universities in the country, of which we are one. We can get the identity with both academic excellence and hopefully athletic excellence."

-Add Sweer "Our geographical location is a' handicap because there are not many Division III teams in the West." The basketball team has to ask the NCAA for waiver of a rule stating that a team must play fifty. percent of its games against Division III instinutions because of they can't schedule enough local schools.

Item: Coaching at UCSD

-Three of the main concems of UCSD coaches are "a lack of - commitument to the program on the part of the administration, lack of recognition and support by UCSD, and extremely low salaries." - Registration Fẹe Committee intem Katy Haberkem.

- Coaches at UCSD make between $\$ 6,000$ and $\$ 13,000$. -Coaches do not receive : benefics:

-:It's very pompous fort us to beat our chests and. say what a great athletic program we have with almost atl part time coaches. In fact, it's ludicrous." - Barry Cuniningham, physical education instructor.

"The administration does not go out of its way to help you or make you feel wanted." Marshall.

-It's frustrating to give everything you've got into a. program and have constraints that keep the program from being even betrer. We don't have enough facilities, we don't have enough funding, and the coaches 'don't even have offices. I understand the position of the administration and professors. and $I$ also. feel excellence in academics is the priority. But I wish they would realize the importance of a good athleric program for the school and the students - both players and fans." Judy Malone, UCSD women's.basketball coach.

-A lot of coaches that have come here with some great new ideas have been stepped on and smashed so many times that they say 'Fuck it I can't oke it any more. I'm busting my butr and I ain't getting shit for it:" $-A$ coach at UCSD.

- Coaches coming into our program should realize the Division III. philsophy and if they can't agree with it, there are many other Division I schools that can hire their services." Andy Skief, assistant athletic director, and urack and field coach.

-You really can't expect-any athletic program to improve without full time coaches." - Bill Motgan, UCSD swim coach. -ln order to supplement his income, soccer coach Derek Armsurong coaches the local Nomads clib.

- Marshall has two other jobs to help his own finances.

- Skief is the only coach who is a full time faculty member:

Part two of this investigative report will deal with attendance, recouiting and fundraising

Flip Harrison arid Katy Halberkem contributed to this article. 


\section{APPENDIX F}

Reproduced with permission of the copyright owner. Further reproduction prohibited without permission. 


\section{RESPONSE ANALYSIS FORM}

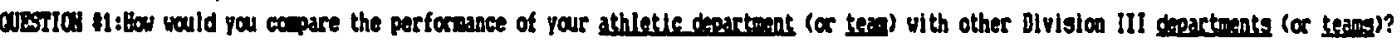

A.D.'S RRspouss: Performance defined as success?...teans...je are one of the wost coupeticive DIII teans in the country, as evidenced by the nuther of cheplonships el ther won ox partleipated in the last year.

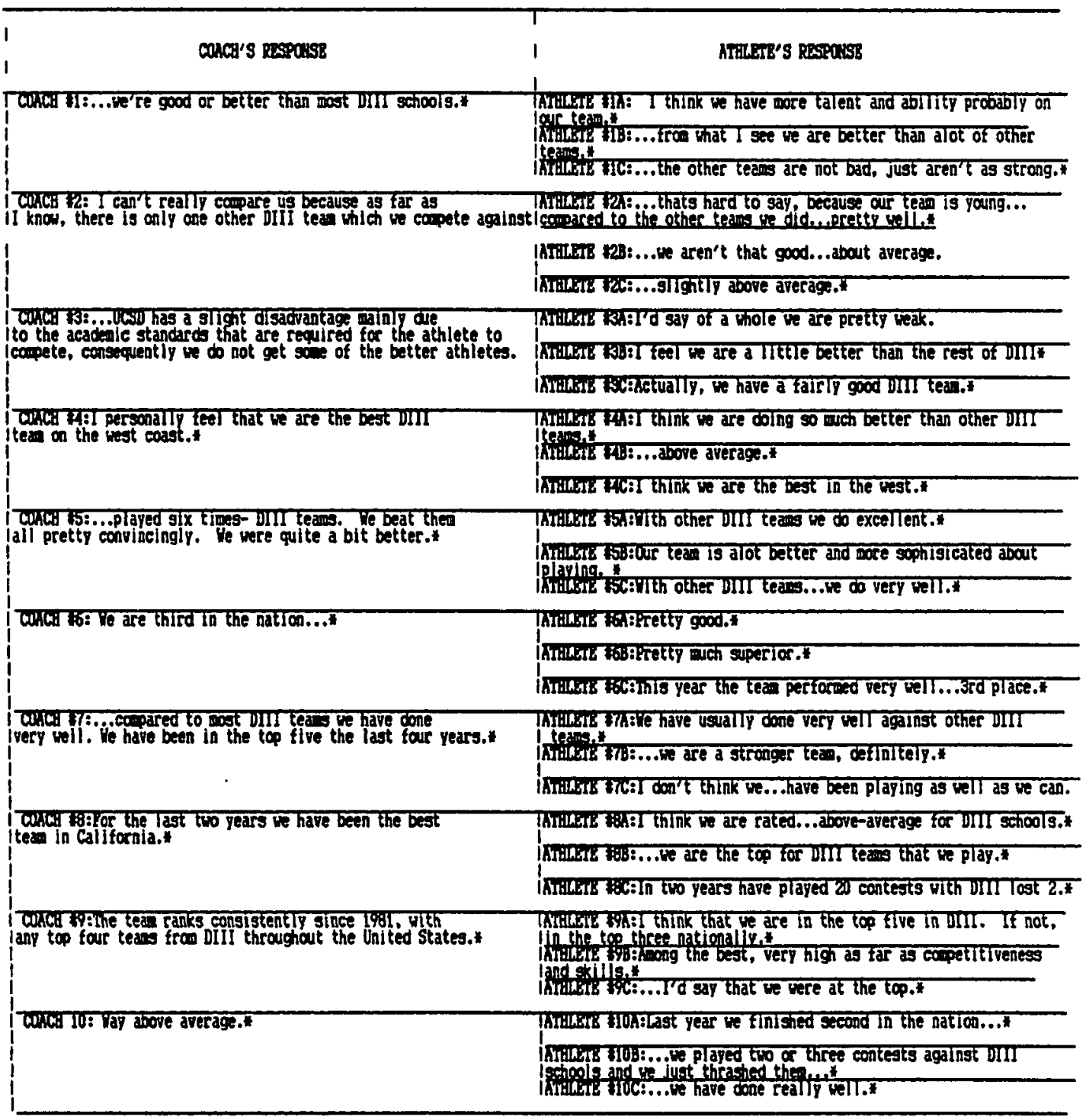

$*=$ response that agrees vith athletic Director $\quad$ of igreenent $=.875$ Responses that agree $=35$ of 40 


\section{RESPONSE ANALYSIS FORY}

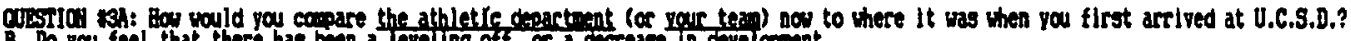
B. Do you teel that there has been a fevieling oft, of a dictease in developent.

A.D.' 9 Resecassitie were not as comptitive $\infty$ a national level at all...had a spocts club atwoephere. Improvement.

\begin{tabular}{|c|c|}
\hline COAGA'S RESPCOSB & AmiLETI'S RQSPQASP \\
\hline 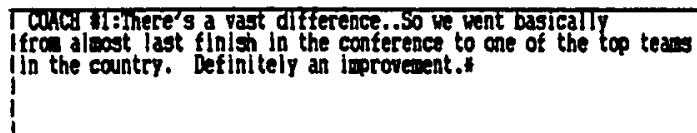 & 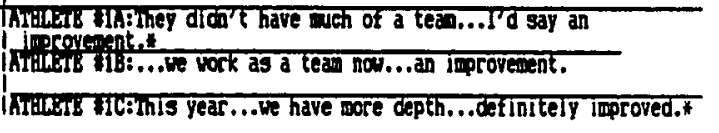 \\
\hline 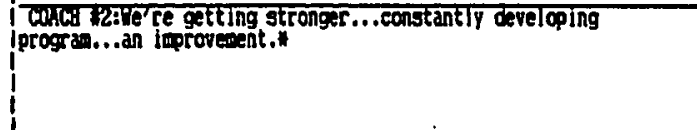 & 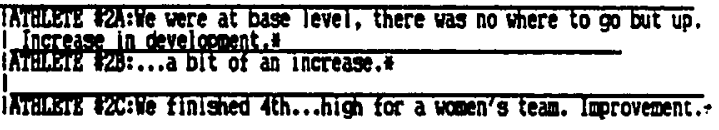 \\
\hline 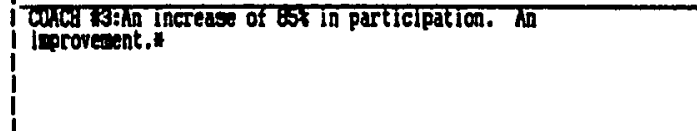 & 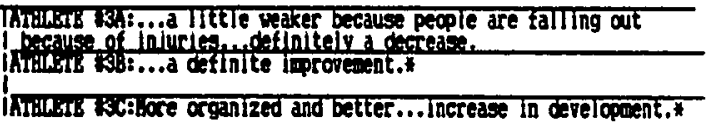 \\
\hline 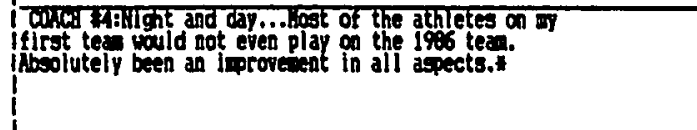 & 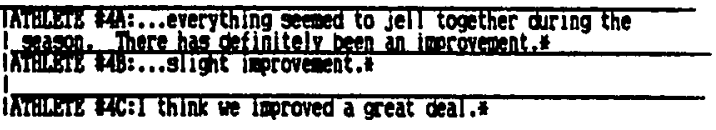 \\
\hline 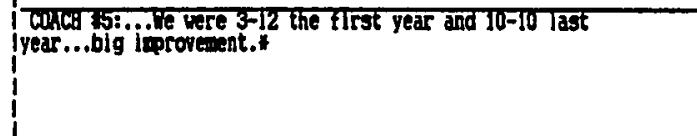 & 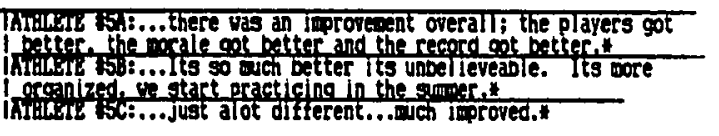 \\
\hline 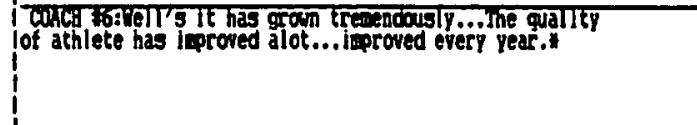 & 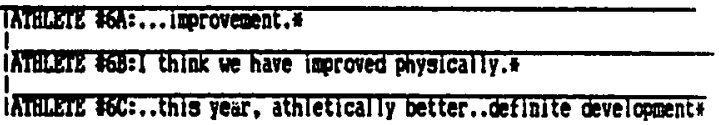 \\
\hline 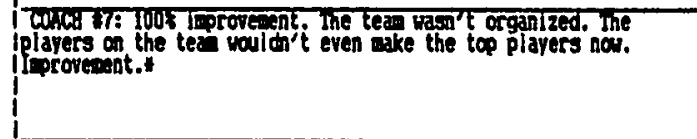 & 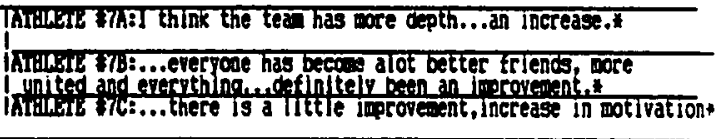 \\
\hline 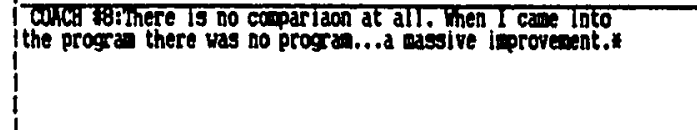 & 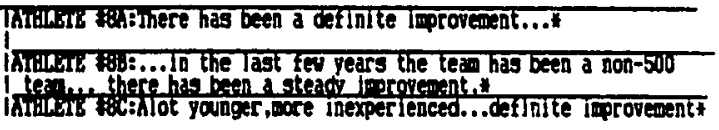 \\
\hline 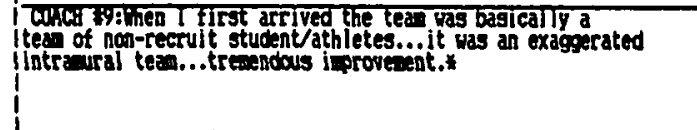 & 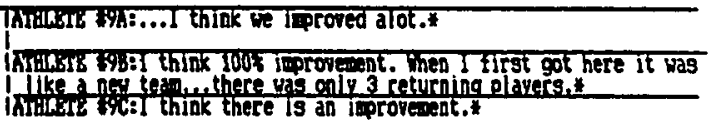 \\
\hline 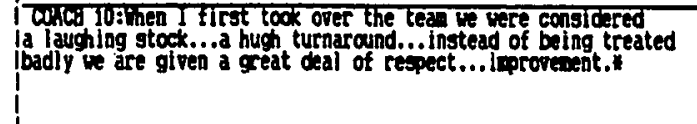 & 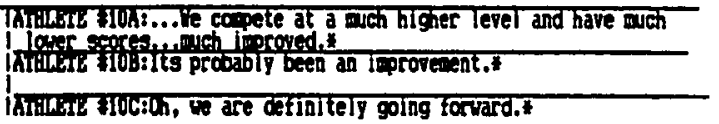 \\
\hline
\end{tabular}

we response that agrees vith Athletlc Director

* of igreesent $=.975$

Responses that agree $=99$ of 40 
RESPONSE_ANALYSIS EORY

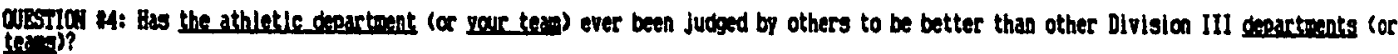

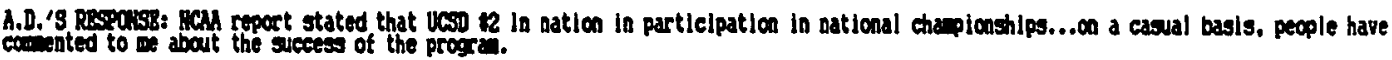

\begin{tabular}{|c|c|}
\hline COAGi's RESPLists & ARTLETE'S RESPOASE \\
\hline 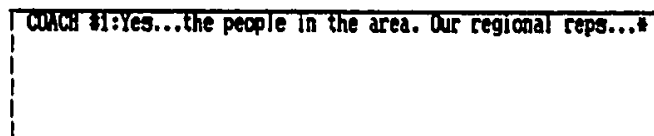 & 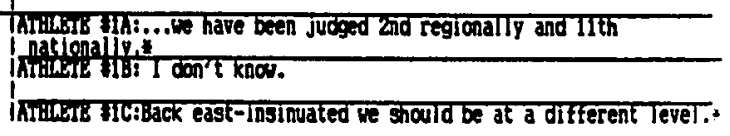 \\
\hline 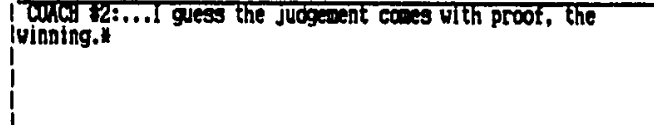 & 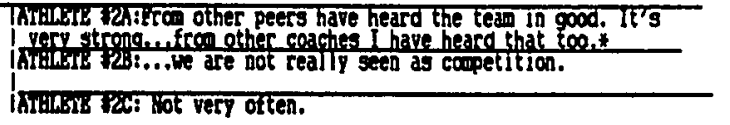 \\
\hline Cunct is: 1 k. & 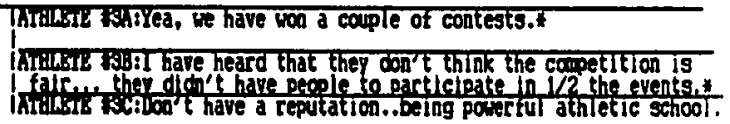 \\
\hline 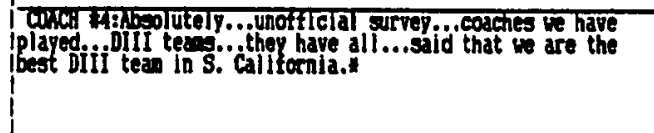 & 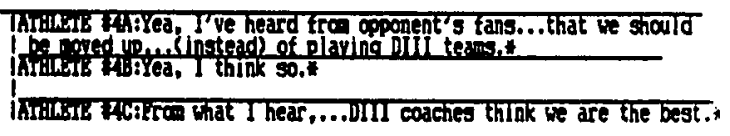 \\
\hline 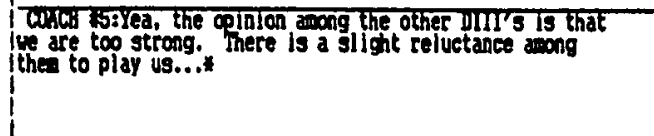 & 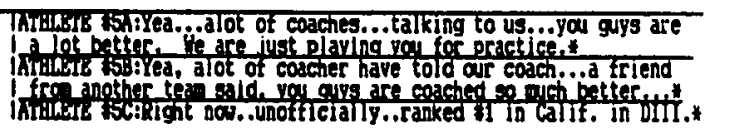 \\
\hline 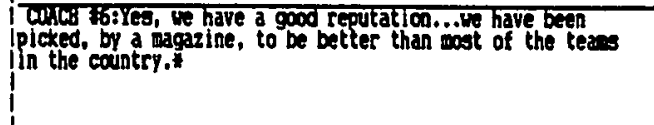 & 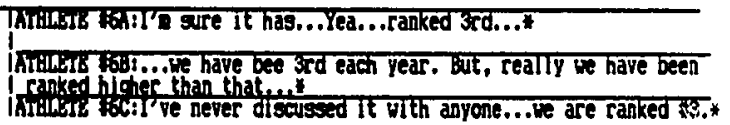 \\
\hline 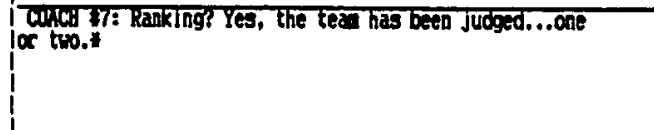 & 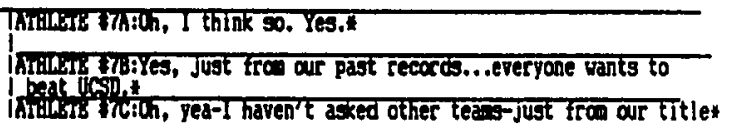 \\
\hline 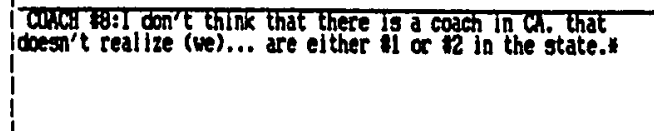 & 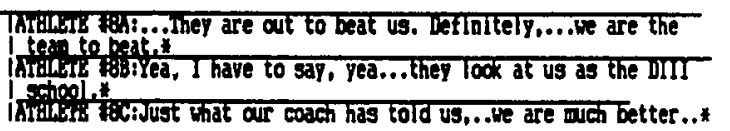 \\
\hline 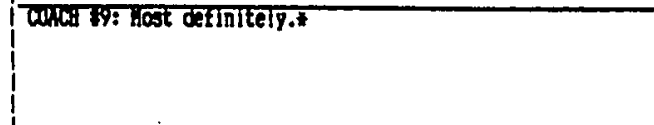 & 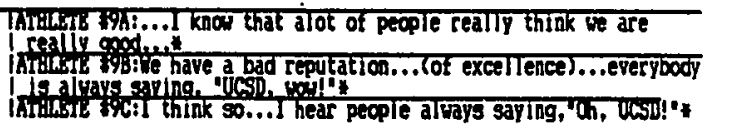 \\
\hline 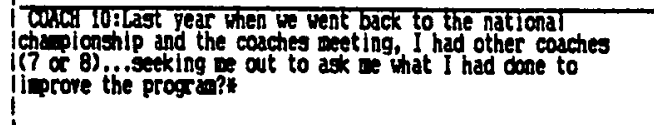 & 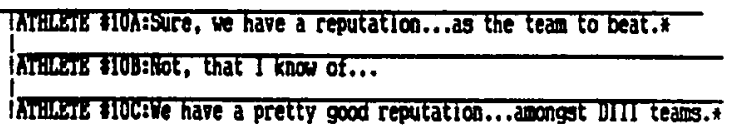 \\
\hline
\end{tabular}

He response that agrees vith Athletic Director \& of Agretent $=.850$ Responses that agree= 34 of 40 
RESPONSE ANALYSIS FORM

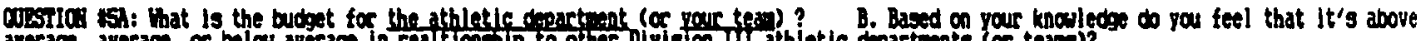

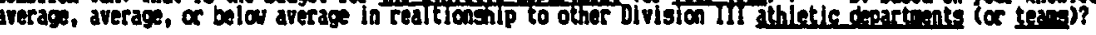

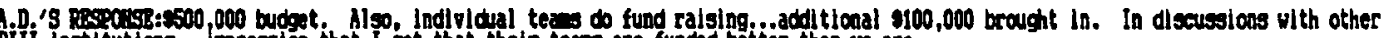
Difi institutions... Inptession that I get that their teans are funded wetier than we are.

\begin{tabular}{|c|c|}
\hline concu's pespeuse & ATHLET'S RESPLESS \\
\hline 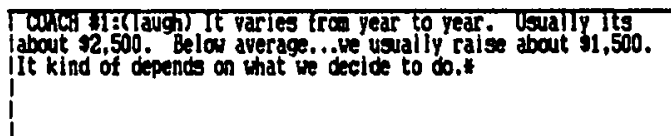 & 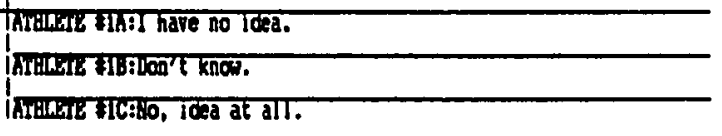 \\
\hline 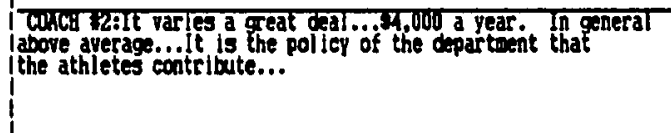 & 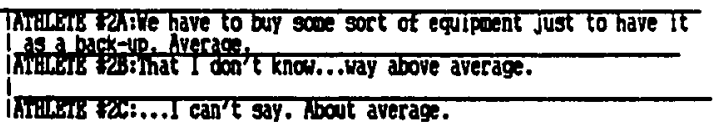 \\
\hline 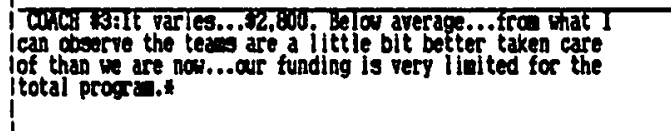 & 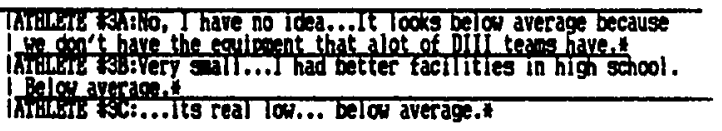 \\
\hline 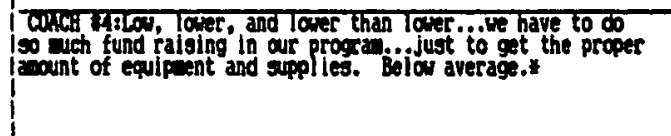 & 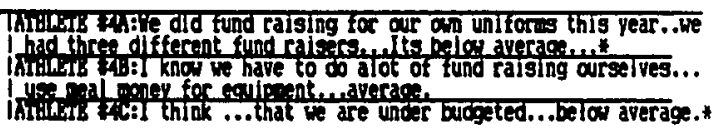 \\
\hline CWhad कI really can't reweter. & 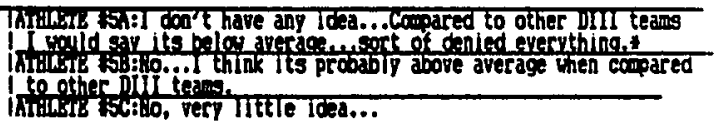 \\
\hline 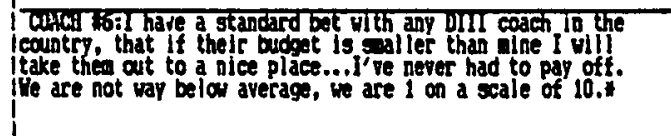 & 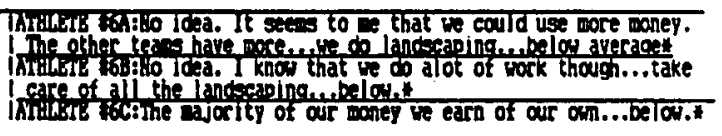 \\
\hline 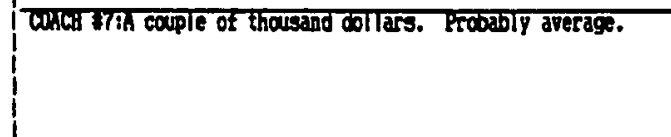 & 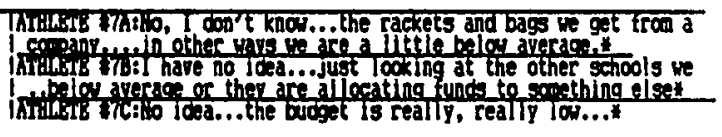 \\
\hline 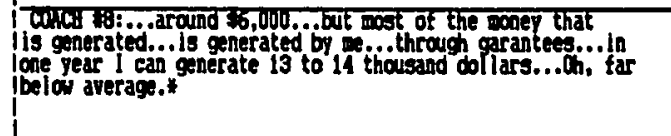 & 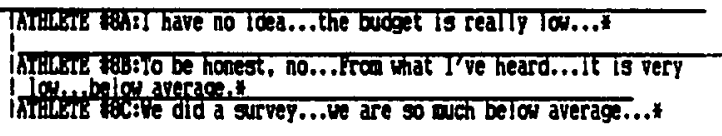 \\
\hline 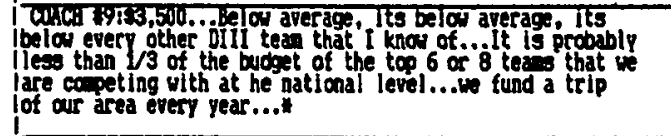 & 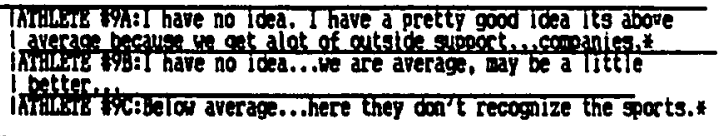 \\
\hline 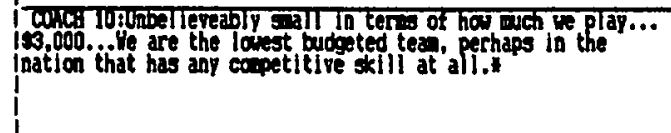 & 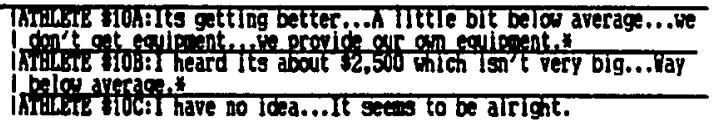 \\
\hline
\end{tabular}

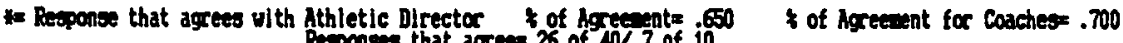




\section{RESPONSE ANATYSTS FORY}

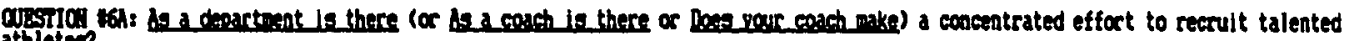

A.D.'S Raspouse: Generally res, sone cosches are ane active and better at it than others...cone coaches hardly get lavolved and don't take the initative.

\begin{tabular}{|c|c|}
\hline Conca's RESPCotse & ATRLEII'S RESPUISB \\
\hline 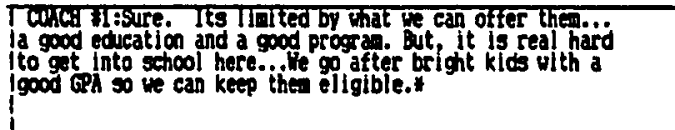 & 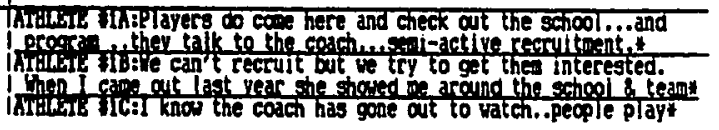 \\
\hline 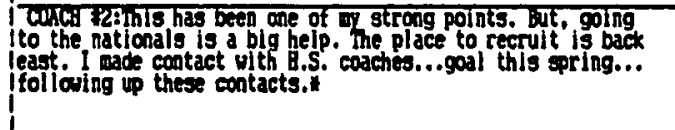 & 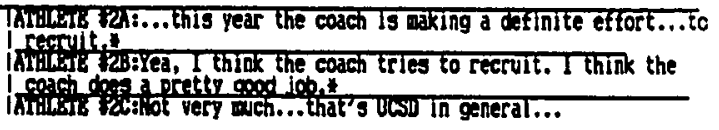 \\
\hline \multirow{3}{*}{ 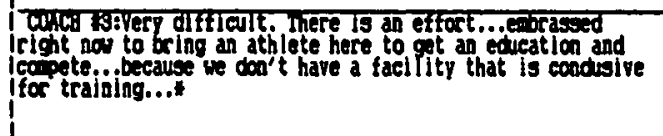 } & NI bor't think the codch really does. \\
\hline & Bato tar as I knom, no. \\
\hline & 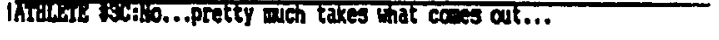 \\
\hline \multirow[t]{2}{*}{ 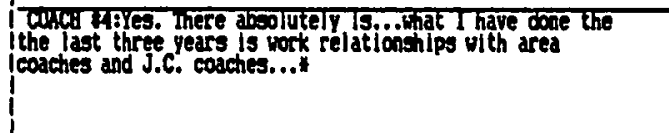 } & 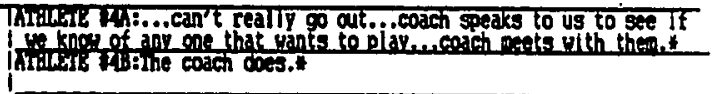 \\
\hline & fC: think the cosch bes.... \\
\hline \multirow{3}{*}{ 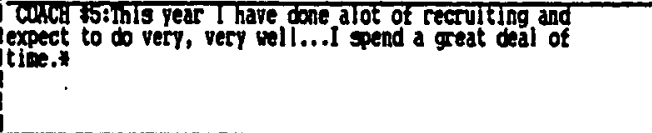 } & 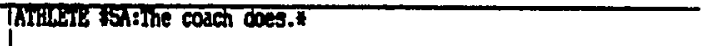 \\
\hline & 3:Prea, this yed the cosch 19.; \\
\hline & C:Yea, the cosch does.: \\
\hline \multirow{3}{*}{ 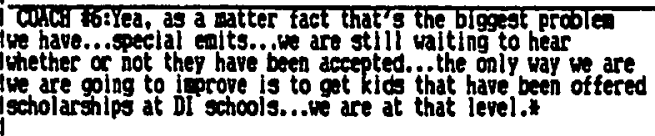 } & Shal know the codch boes.t" \\
\hline & being cosec oces. \\
\hline & 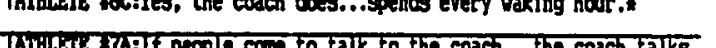 \\
\hline \multirow[t]{2}{*}{ canct Br:Yes, there 19.t } & 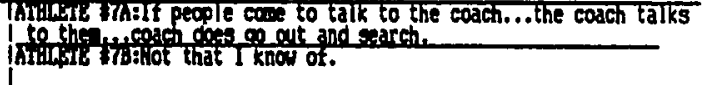 \\
\hline & 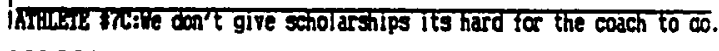 \\
\hline \multirow{2}{*}{ 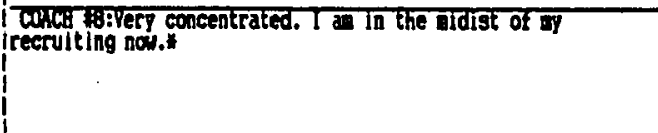 } & 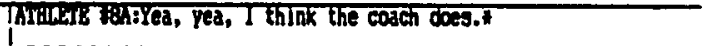 \\
\hline & 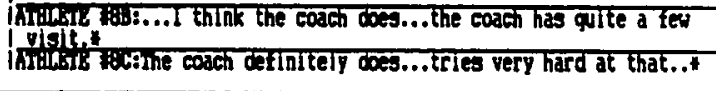 \\
\hline Coxher Woldefinitely.t & 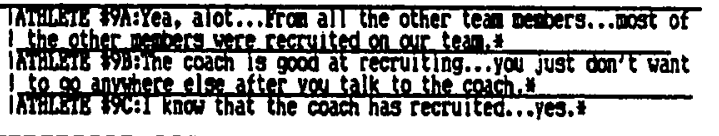 \\
\hline \multirow{2}{*}{ 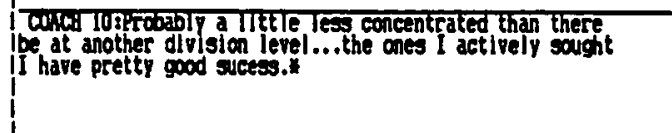 } & 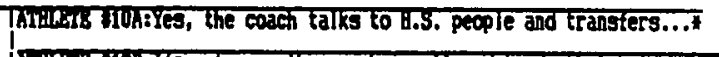 \\
\hline & 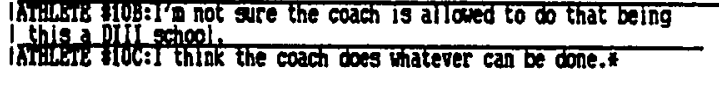 \\
\hline
\end{tabular}

to sesponse that agrees with Athletic Director

$\$$ of horeesent $=.800$

Responses that agrees 32 of 40 
RESPONSE ANALYSIS FORY

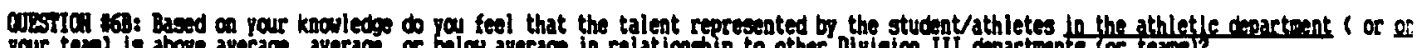

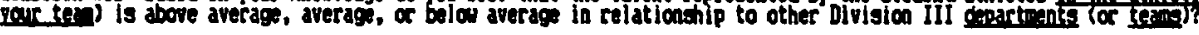

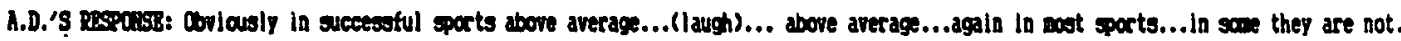

\begin{tabular}{|c|c|}
\hline conog's pesposst & ATHLER'S RESPOASR \\
\hline \multirow[t]{3}{*}{ 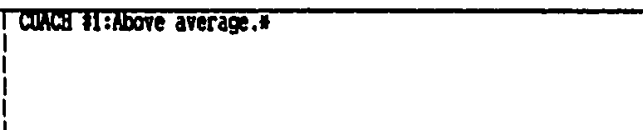 } & 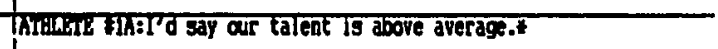 \\
\hline & 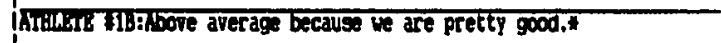 \\
\hline & 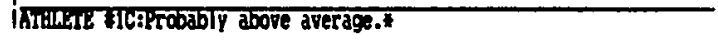 \\
\hline \multirow{3}{*}{$\begin{array}{l}\text { culch te: can't give you do answer on taleat...experience, } \\
\text { laverage or below dverage. }\end{array}$} & 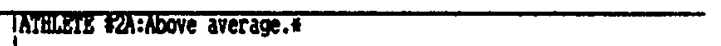 \\
\hline & intildire Tid:....average. \\
\hline & 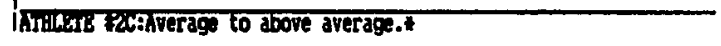 \\
\hline \multirow[t]{2}{*}{ Cunced walt is... overall... dverage. } & 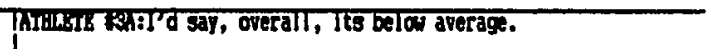 \\
\hline & 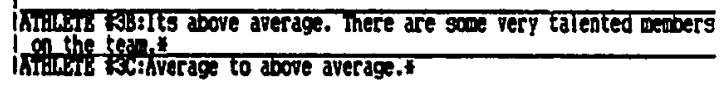 \\
\hline \multirow[t]{3}{*}{ Cuhci hatbove averdge, no question.... } & 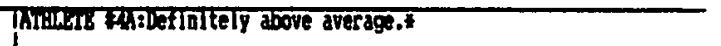 \\
\hline & 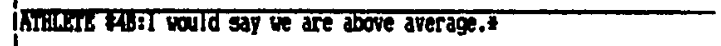 \\
\hline & 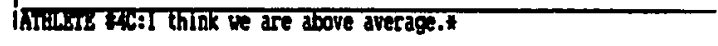 \\
\hline \multirow[t]{3}{*}{ cuhchi bis:... above average.5 } & 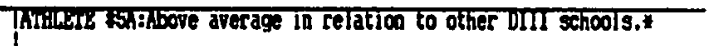 \\
\hline & 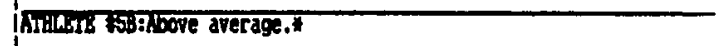 \\
\hline & 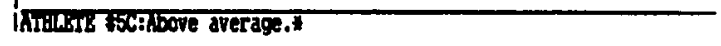 \\
\hline \multirow{3}{*}{ 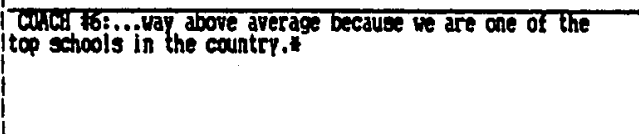 } & Thitheirt washove average. \\
\hline & 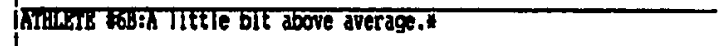 \\
\hline & 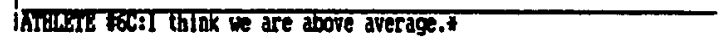 \\
\hline \multirow[t]{3}{*}{ 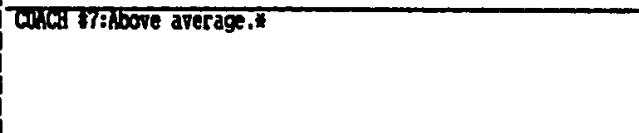 } & Thitikent brat think it is above average. 7 \\
\hline & hridbili Trbabove average.I \\
\hline & 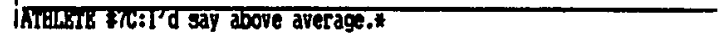 \\
\hline \multirow{3}{*}{ 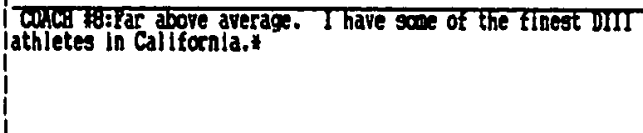 } & 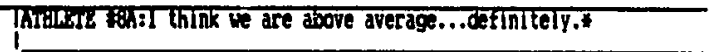 \\
\hline & 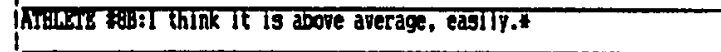 \\
\hline & 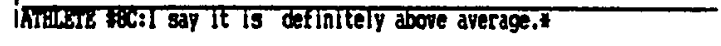 \\
\hline \multirow{3}{*}{ 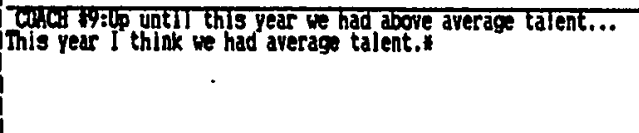 } & Thribure Fyar think it is abore average." \\
\hline & Artharb s98:Above dverage, atinitely.* \\
\hline & 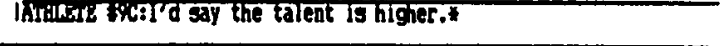 \\
\hline \multirow[t]{2}{*}{ Curcid lostar above average..." } & 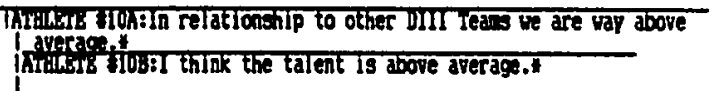 \\
\hline & 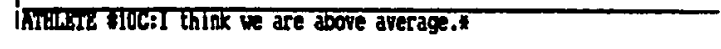 \\
\hline
\end{tabular}

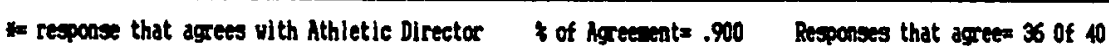




\section{BESPONSE ANALYSIS FORY}

OJSSIOA 17: How would you compare the athletic facilities at U.C.S.D. with other Division III institutions: above average, average, or
below average?

A.D.'S Reseonst:...tacilities are inadequate...athletics, intraurals, recceation. Consequently facilities are over cronded...average te below average.

\begin{tabular}{|c|c|}
\hline COACH'S REAPUES & MHELETE'S RESPOUSR \\
\hline \multirow{3}{*}{ 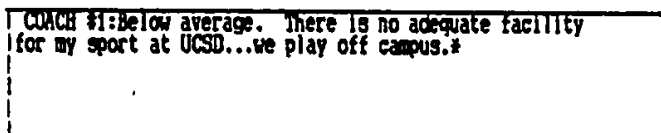 } & 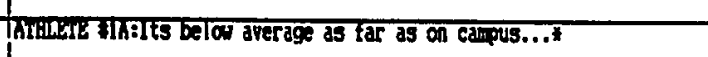 \\
\hline & 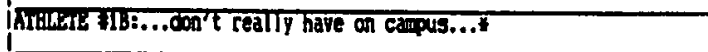 \\
\hline & 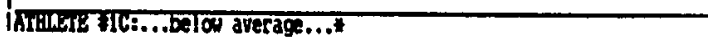 \\
\hline \multirow[t]{3}{*}{ 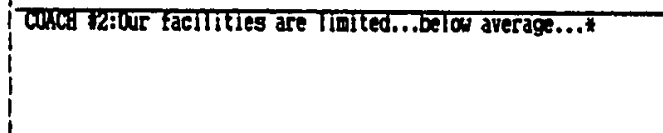 } & Thrillite wastbove average. \\
\hline & 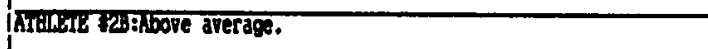 \\
\hline & 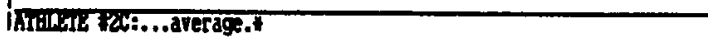 \\
\hline \multirow[t]{2}{*}{ 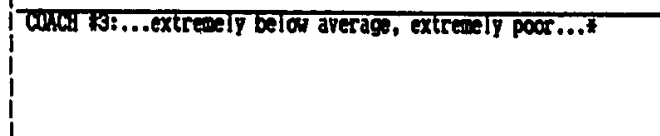 } & 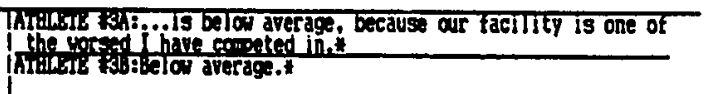 \\
\hline & 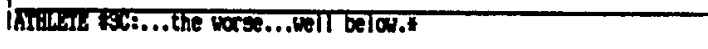 \\
\hline \multirow[t]{2}{*}{ 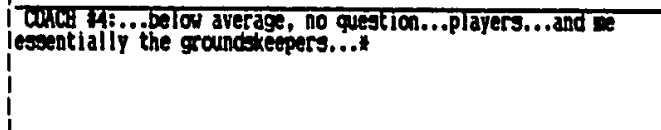 } & 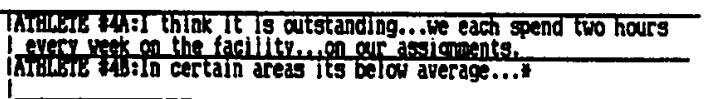 \\
\hline & IArideres flt:... on the arerage scale.* \\
\hline \multirow{2}{*}{ 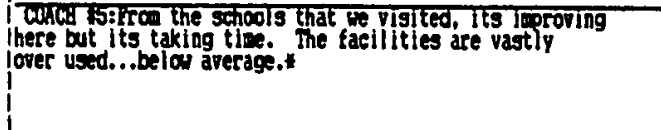 } & 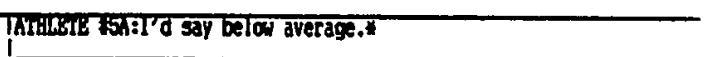 \\
\hline & 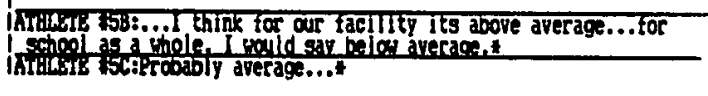 \\
\hline \multirow{2}{*}{ 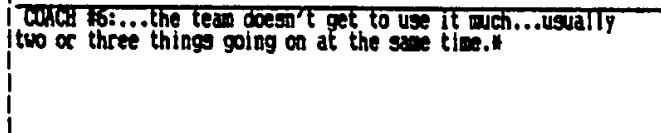 } & Thribeis Fot: hreraget \\
\hline & 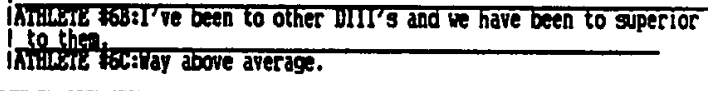 \\
\hline \multirow[t]{2}{*}{ 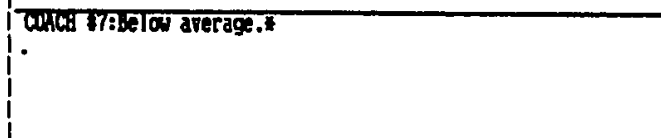 } & 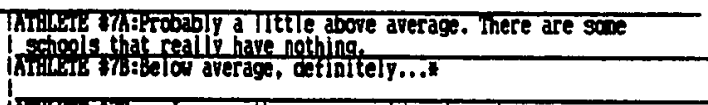 \\
\hline & 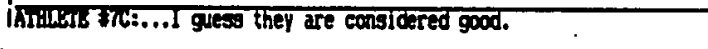 \\
\hline \multirow{3}{*}{ 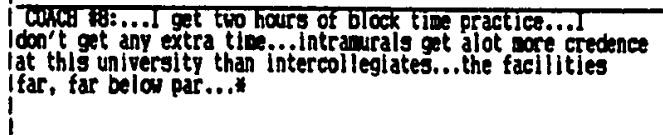 } & 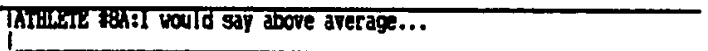 \\
\hline & 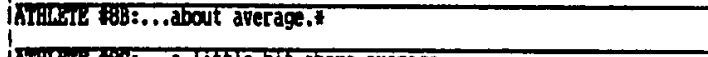 \\
\hline & 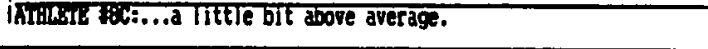 \\
\hline \multirow{3}{*}{ 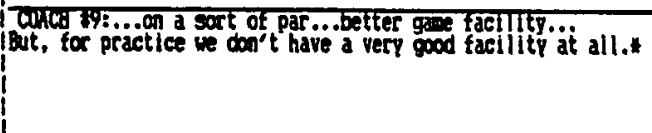 } & 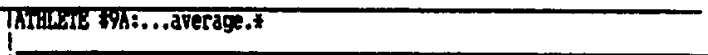 \\
\hline & 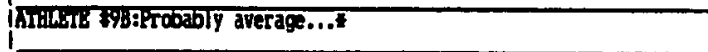 \\
\hline & 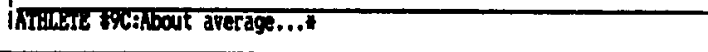 \\
\hline \multirow[t]{3}{*}{ conhar los bove average. } & 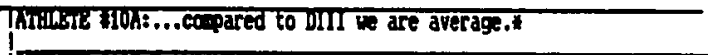 \\
\hline & 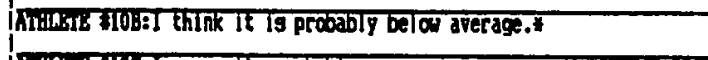 \\
\hline & 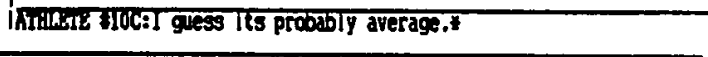 \\
\hline
\end{tabular}

* response that agrees with Athletic Directoc i of Agreesent= .750 Responses that agrec= 30 of 40 
RESPONSE ANALYSIS FORY

Cussian \$10C: Hould you say the athletle departent better reflects Its on wulture rather than the university as a whole?

A.D.'S Respruse: Yes...creflects ofe its an.

\begin{tabular}{|c|c|}
\hline Congr's RLSPLise: & ATHLETE'S RESPCASB \\
\hline \multirow[t]{3}{*}{ Wothe in: Yes..." } & 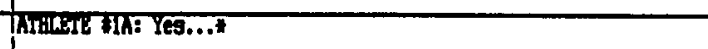 \\
\hline & 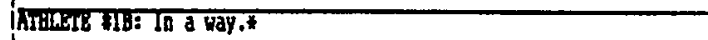 \\
\hline & 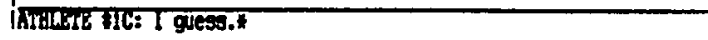 \\
\hline \multirow{2}{*}{ Cuket P2: I can't answer that. } & TAriLEIE P2A: Yes." \\
\hline & 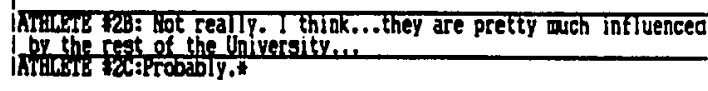 \\
\hline \multirow{3}{*}{ 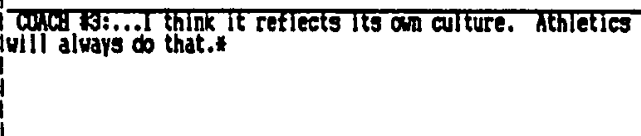 } & 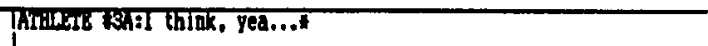 \\
\hline & 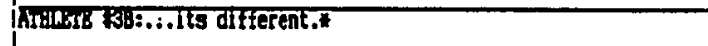 \\
\hline & inrillide kit:...Its on. \\
\hline \multirow[t]{3}{*}{ 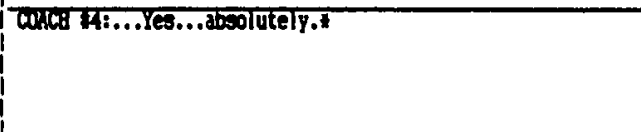 } & ThridEIE wh: Yea, I saf it would. \\
\hline & 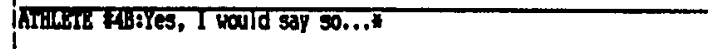 \\
\hline & 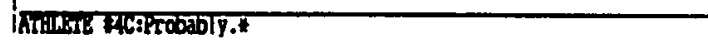 \\
\hline \multirow[t]{3}{*}{ Coket $5: . . .1$ don't know. } & 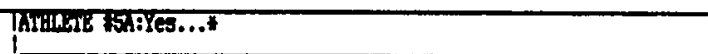 \\
\hline & Arathere bis: Yea." \\
\hline & 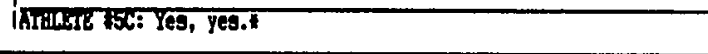 \\
\hline \multirow[t]{3}{*}{ 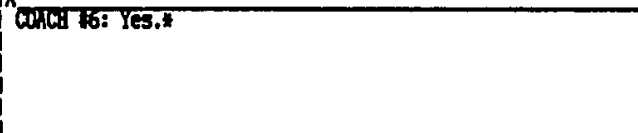 } & 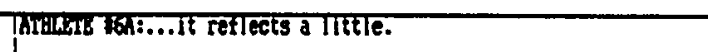 \\
\hline & 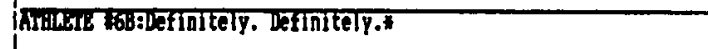 \\
\hline & 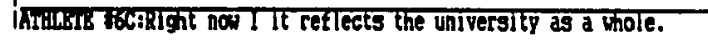 \\
\hline \multirow[t]{3}{*}{ 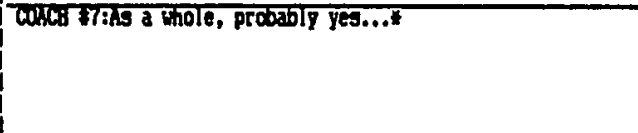 } & 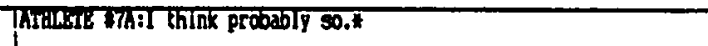 \\
\hline & 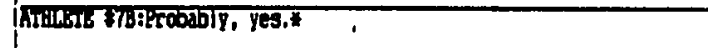 \\
\hline & intelaste the:...has different values..." \\
\hline \multirow[t]{3}{*}{ 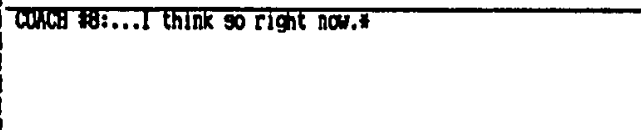 } & 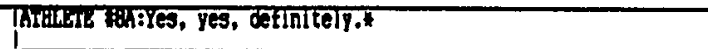 \\
\hline & 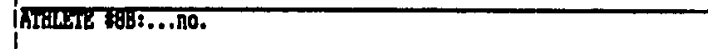 \\
\hline & intiblese bes don't think so. \\
\hline \multirow[t]{3}{*}{ 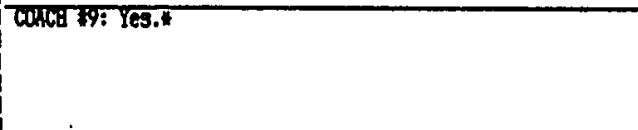 } & 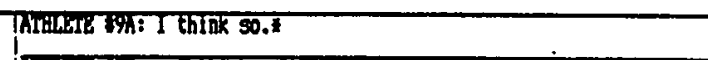 \\
\hline & 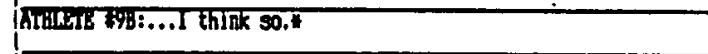 \\
\hline & Antilhente fyctYes, I think so.f \\
\hline \multirow[t]{3}{*}{ whed lo: I think it coes.t } & 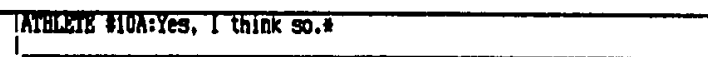 \\
\hline & 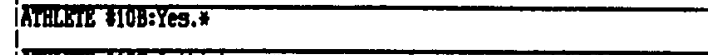 \\
\hline & 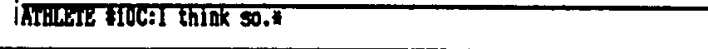 \\
\hline
\end{tabular}

* Response that agrees vith Athietic Directoc $\quad$ of Agreenent=.825 Responses that agree=30 of 40 
RESPONSE ANALYSIS_FORM

OBSTIOA H1h: that would you say are the broad purpowes of the athletle department of U.C.S.D. ?

A.0.'S Resposse:To propice positive coportunities for participa!!m for student/athletes to allow thea to reach maximan potential as comptitacs. To generate spirit and visibility foc the university and to bring together as wech of the student body Inorder to develop sense of fanily.

\begin{tabular}{|c|c|}
\hline cosca's Respuise & ATELETE'S RESPOASB \\
\hline 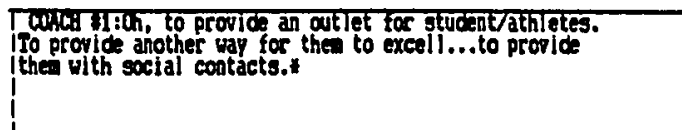 & 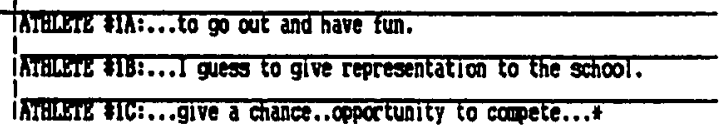 \\
\hline 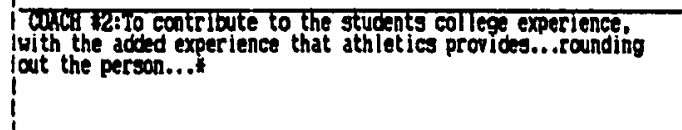 & 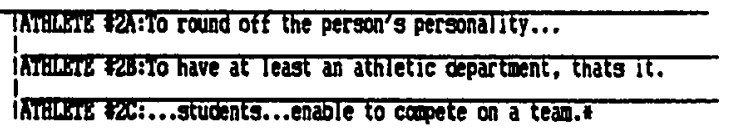 \\
\hline 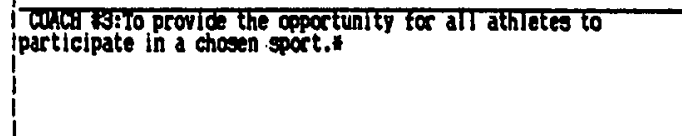 & 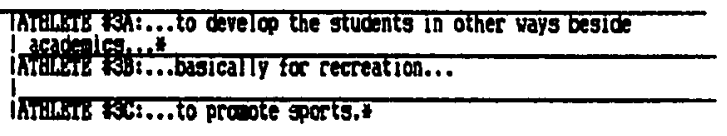 \\
\hline 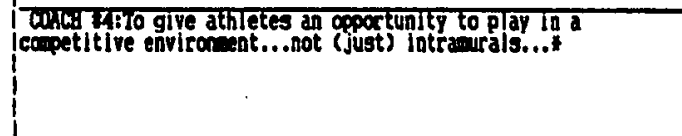 & 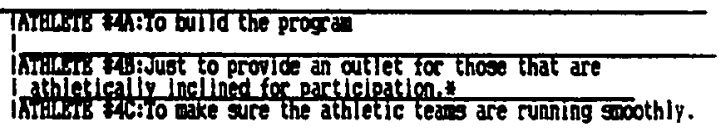 \\
\hline 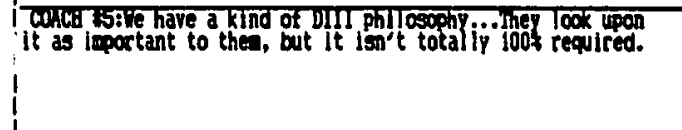 & 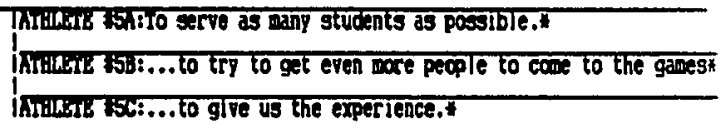 \\
\hline 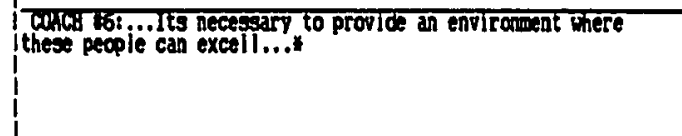 & 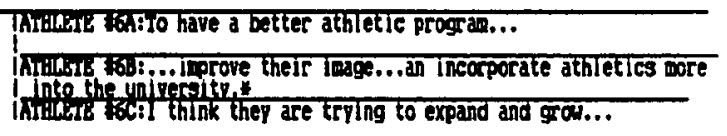 \\
\hline 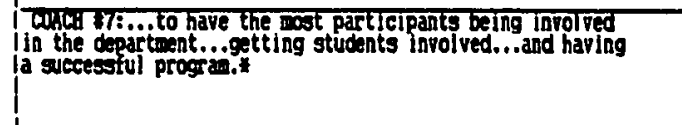 & 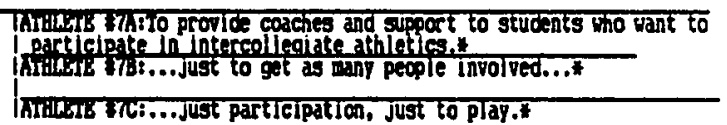 \\
\hline 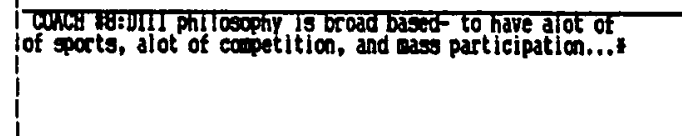 & 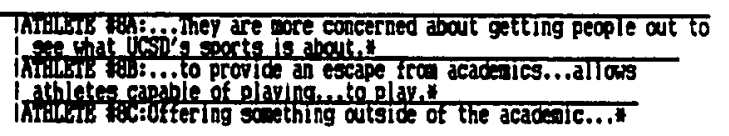 \\
\hline 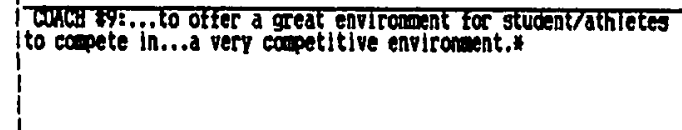 & 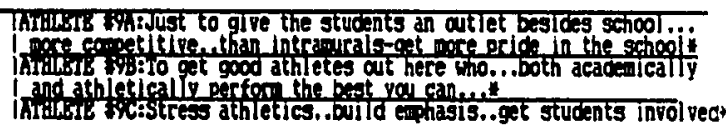 \\
\hline 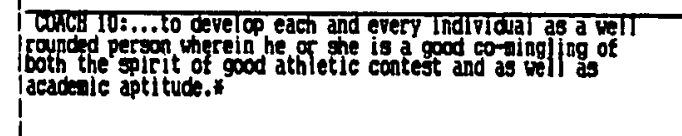 & 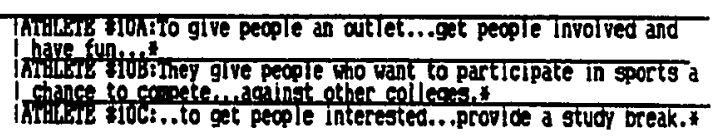 \\
\hline
\end{tabular}

* Response that agress vith Athletic Director

i of haresent= .700

Responses that agree 28 of 40 


\section{RESPONSE ANALYSIS FORM}

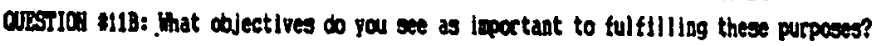

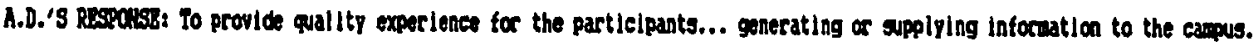

\begin{tabular}{|c|c|}
\hline COAGA'S RESPCHSB & 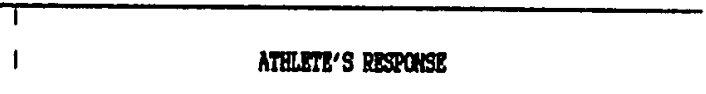 \\
\hline \multirow[t]{2}{*}{ 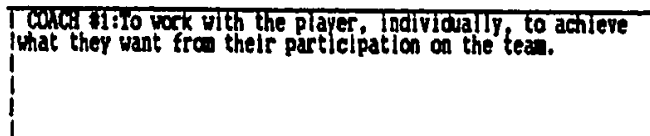 } & 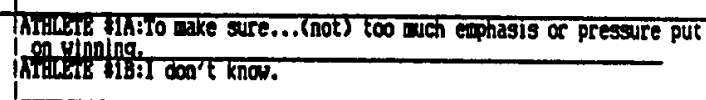 \\
\hline & Ifrilhate trcito answer. \\
\hline 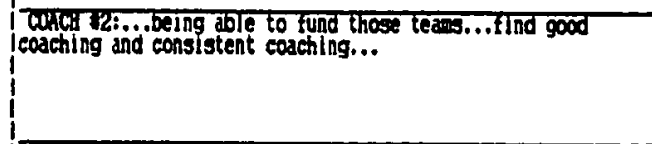 & 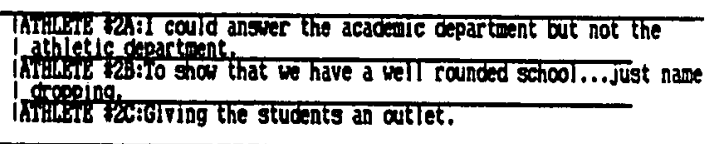 \\
\hline \multirow[t]{2}{*}{ 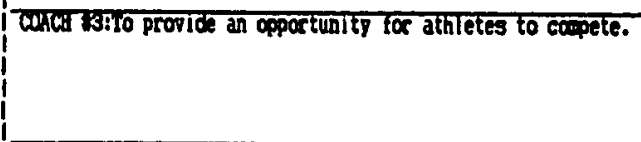 } & 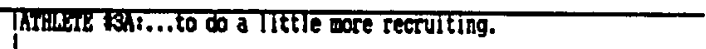 \\
\hline & 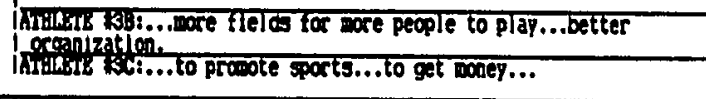 \\
\hline 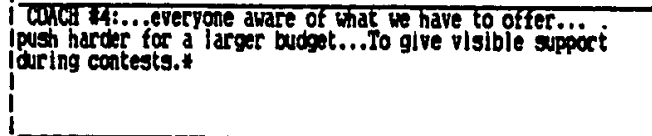 & 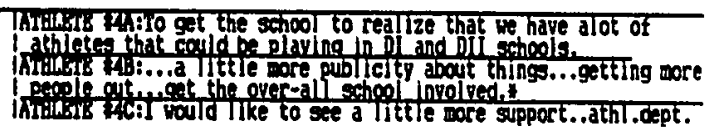 \\
\hline \multirow[t]{3}{*}{ whed t5:... .get crowid out in large minbers. } & 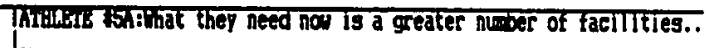 \\
\hline & 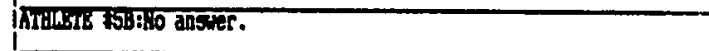 \\
\hline & 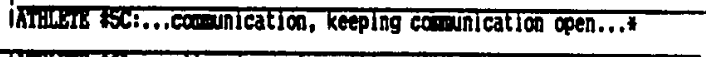 \\
\hline 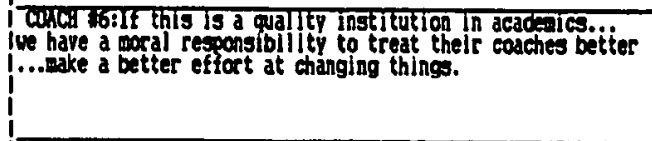 & 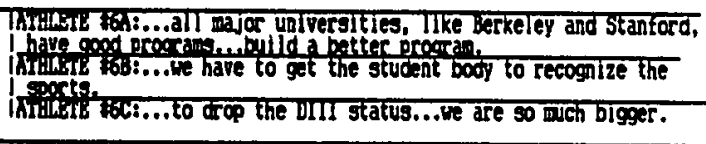 \\
\hline $\begin{array}{l}\text { conch ridining qualikp cosches, salaries for the coaches } \\
\text { iso that we can get qualified pecple. }\end{array}$ & 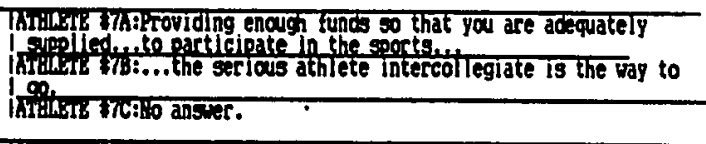 \\
\hline \multirow[t]{3}{*}{ cohes s8n kind of answered that in the last question. } & 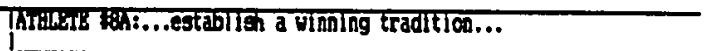 \\
\hline & 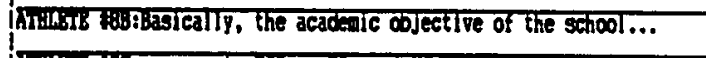 \\
\hline & 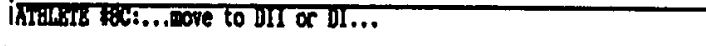 \\
\hline \multirow[t]{2}{*}{ 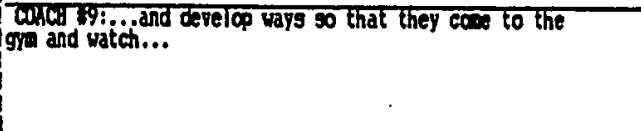 } & 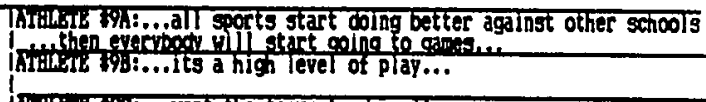 \\
\hline & 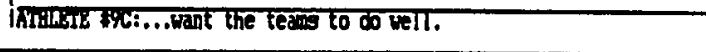 \\
\hline 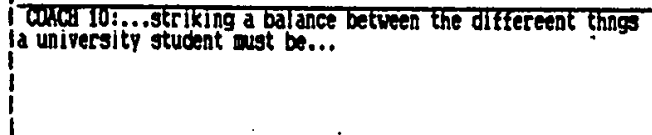 & 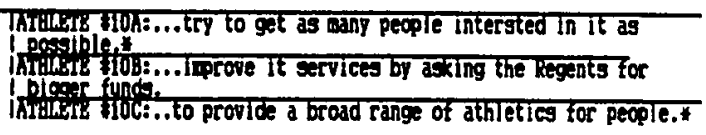 \\
\hline
\end{tabular}

ta Response that agrees with Athletic Director 
BESPONSE_ANALYSIS_EORM

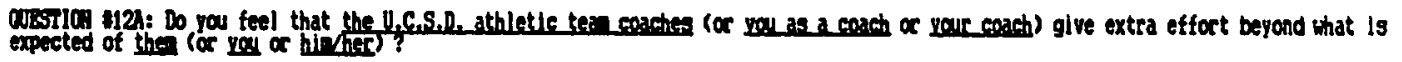

A.D.'S Respouse: . in gnefal they are aking a falrly strong conitnent although mot are part-tine and therefore have reponsiblities

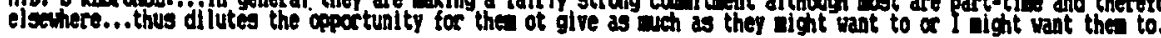

\begin{tabular}{|c|c|}
\hline 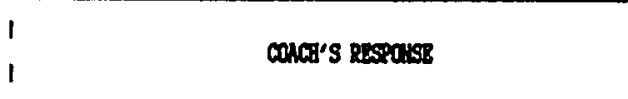 & ATHLETK'S RESPCOSB \\
\hline 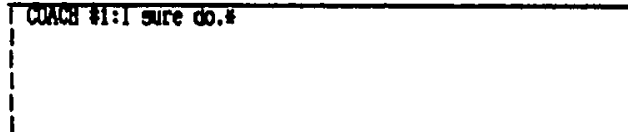 & 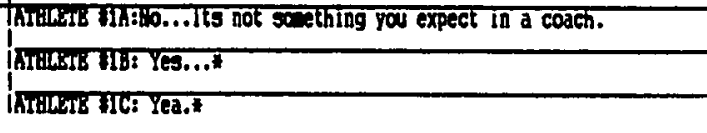 \\
\hline 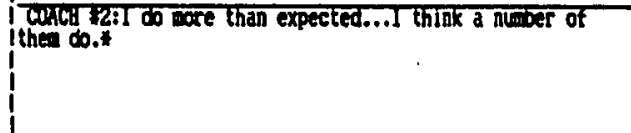 & 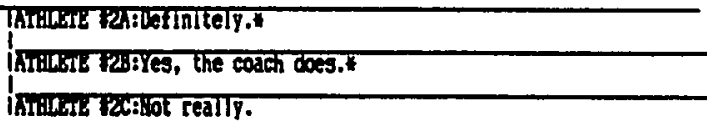 \\
\hline Cothe BS: 150 percent.: & 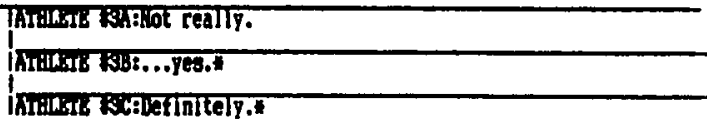 \\
\hline Conkd ADYEs, I 6.\% & 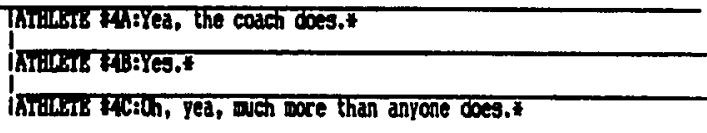 \\
\hline 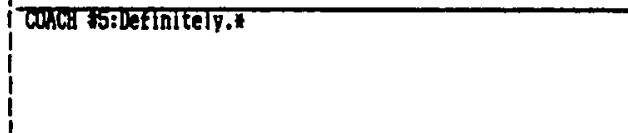 & 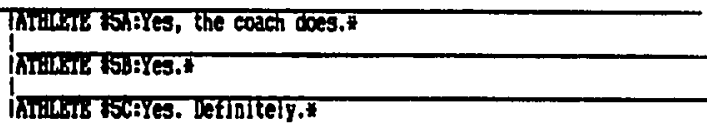 \\
\hline 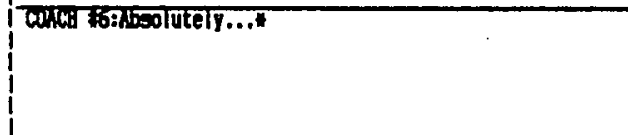 & 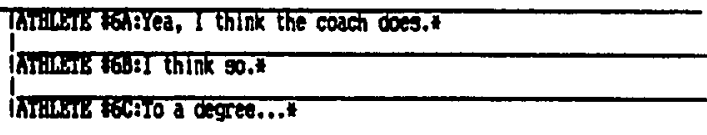 \\
\hline adsuis in: Yes.h & 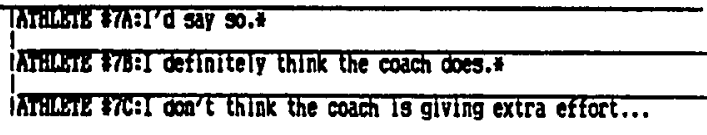 \\
\hline 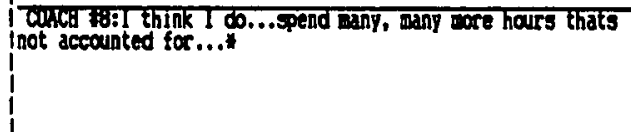 & 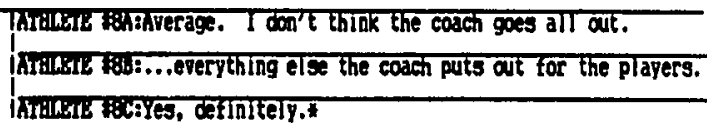 \\
\hline 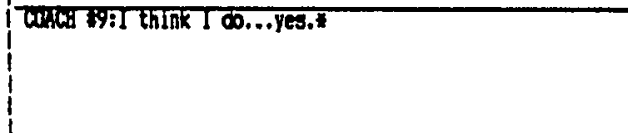 & 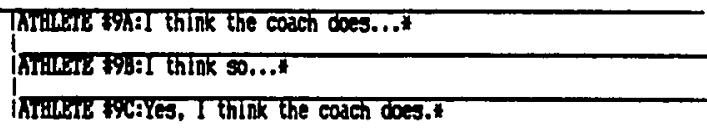 \\
\hline 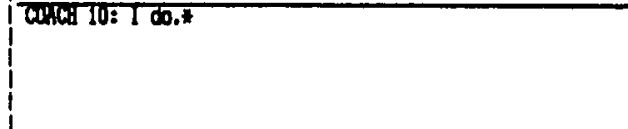 & 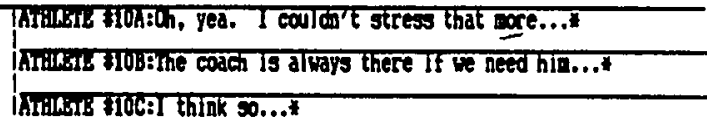 \\
\hline
\end{tabular}

to Response that agrees with Athletic Director i of Agreesent= .650 Responses that agreez 34 of 40 
RESPONSE ANALYSIS EORM

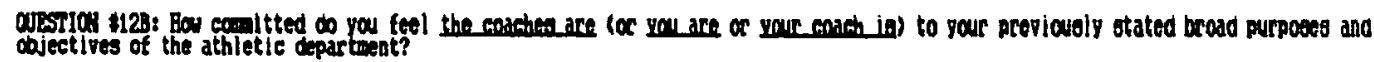

A.D.'S RRspuss: I think they are comitted to thes... sowetiens they might not understand thea all, but from that they understand I think they are supportive.

\begin{tabular}{|c|c|}
\hline COACA'S RESPRISE & ATHETE'S RESPOHSE \\
\hline \multirow[t]{3}{*}{ Coukd H:Very conitted.; } & 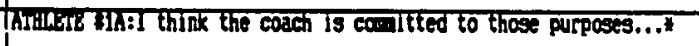 \\
\hline & 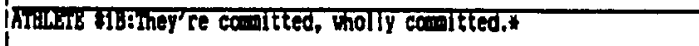 \\
\hline & 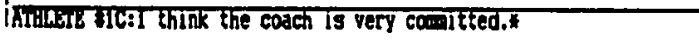 \\
\hline \multirow[t]{2}{*}{ whed fla think their job depends on it..." } & TAR:ALEIB F2A: Yes.* \\
\hline & 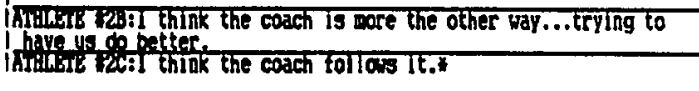 \\
\hline \multirow[t]{3}{*}{ 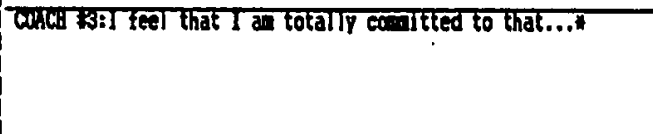 } & 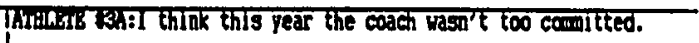 \\
\hline & 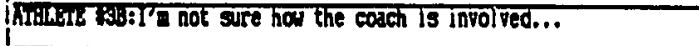 \\
\hline & 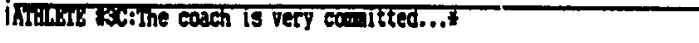 \\
\hline \multirow[t]{2}{*}{ 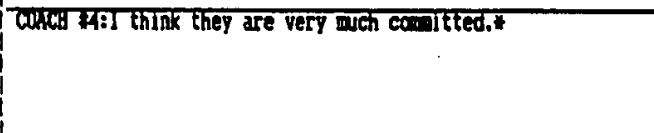 } & 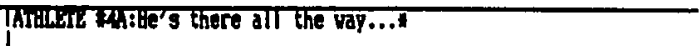 \\
\hline & 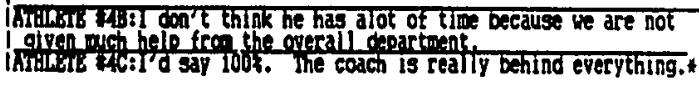 \\
\hline \multirow[t]{2}{*}{ 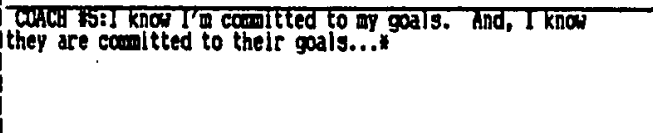 } & 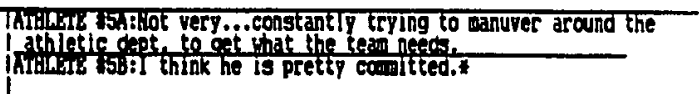 \\
\hline & 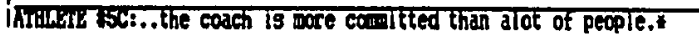 \\
\hline \multirow{3}{*}{ 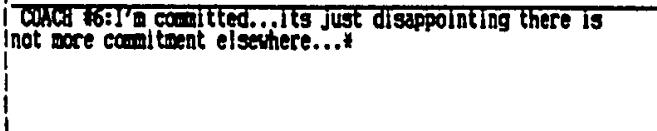 } & 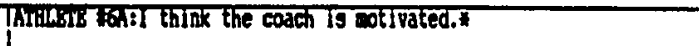 \\
\hline & 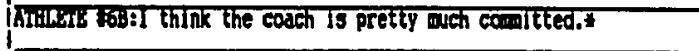 \\
\hline & 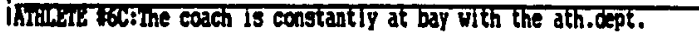 \\
\hline \multirow{3}{*}{ 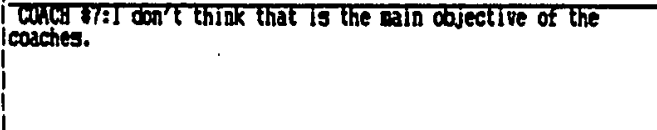 } & 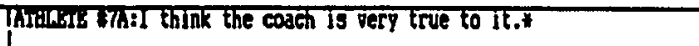 \\
\hline & 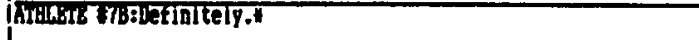 \\
\hline & 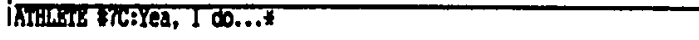 \\
\hline \multirow{2}{*}{ 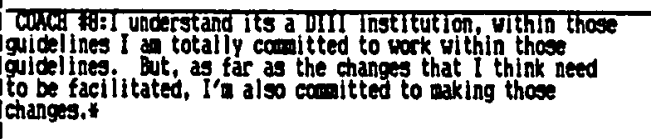 } & 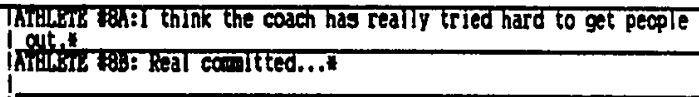 \\
\hline & 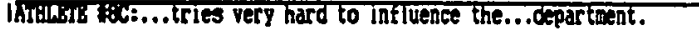 \\
\hline \multirow{3}{*}{ 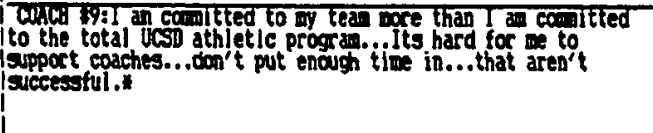 } & Throbere tis: tries..." \\
\hline & 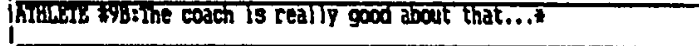 \\
\hline & 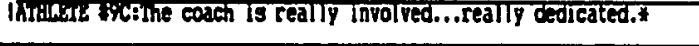 \\
\hline \multirow{3}{*}{ 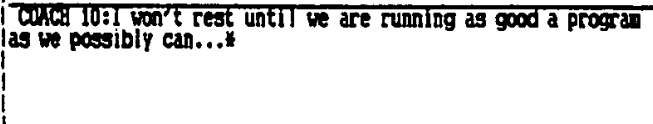 } & 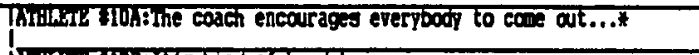 \\
\hline & 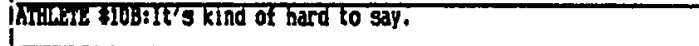 \\
\hline & 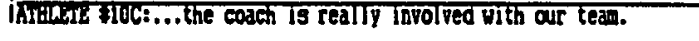 \\
\hline
\end{tabular}

$t=$ Response that agrees with Athletic Director \& of Agrecenent= .750 Responses that agrees $\$ \$ 0$ of 40 
RESPONSE ANATYSIS FORY

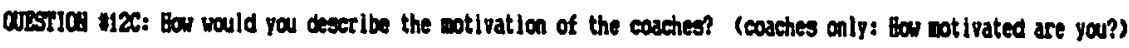

A.D.'S Respoust: For the nost part the coaches are very notivated.

\begin{tabular}{|c|c|}
\hline 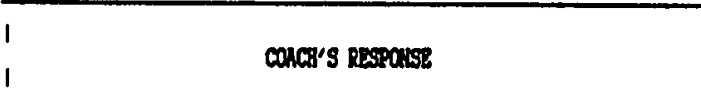 & ATRLETE'S RESPOASE \\
\hline \multirow[t]{2}{*}{ 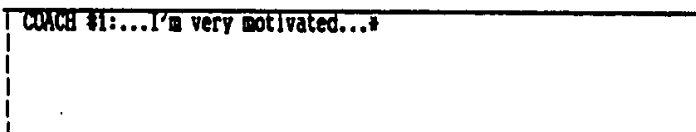 } & 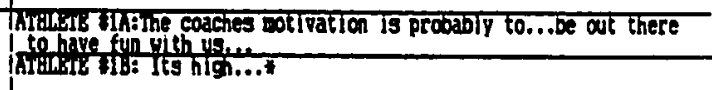 \\
\hline & 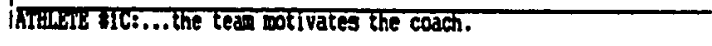 \\
\hline \multirow[t]{2}{*}{ 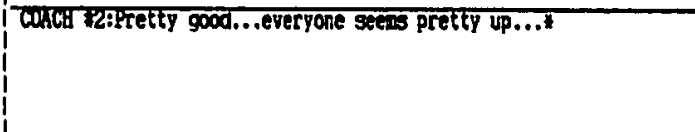 } & 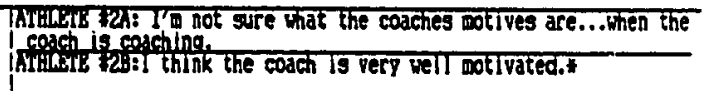 \\
\hline & 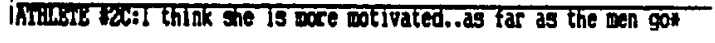 \\
\hline \multirow[t]{2}{*}{ 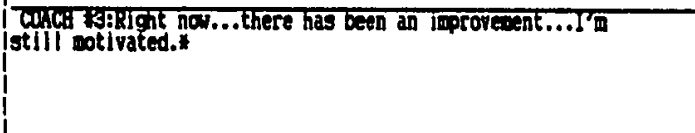 } & 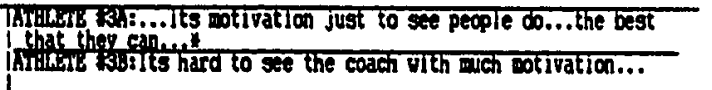 \\
\hline & 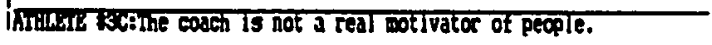 \\
\hline \multirow[t]{3}{*}{ 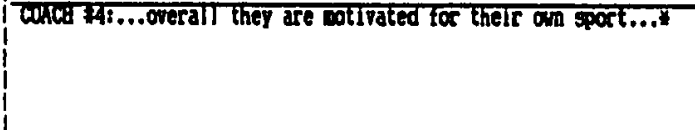 } & 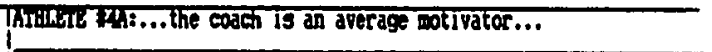 \\
\hline & 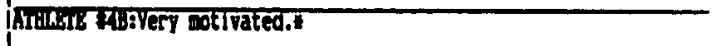 \\
\hline & Ihrabsic atc:Its a wotivation that I Tike.: \\
\hline \multirow{3}{*}{ 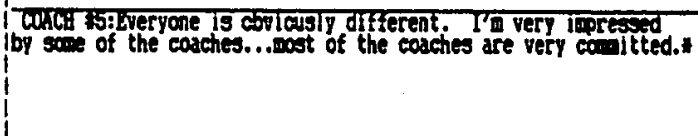 } & 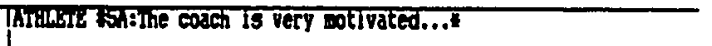 \\
\hline & 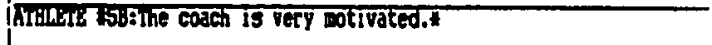 \\
\hline & 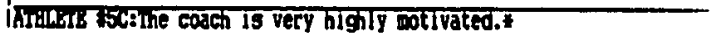 \\
\hline \multirow[t]{3}{*}{ 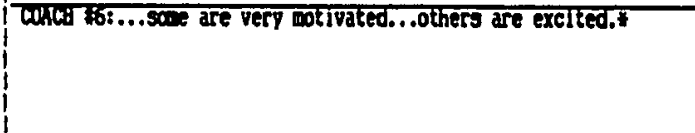 } & 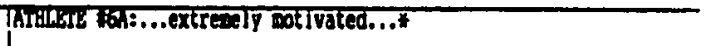 \\
\hline & 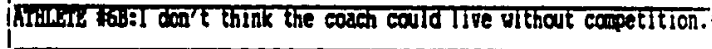 \\
\hline & 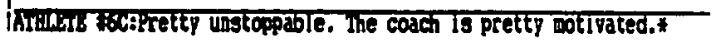 \\
\hline \multirow[t]{2}{*}{ cothed if: think If is very high as a thole... } & 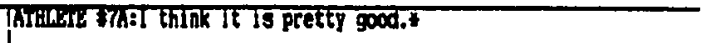 \\
\hline & 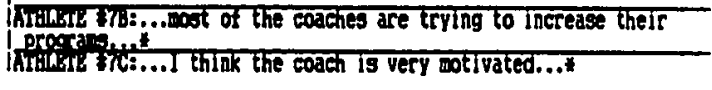 \\
\hline \multirow[t]{3}{*}{ 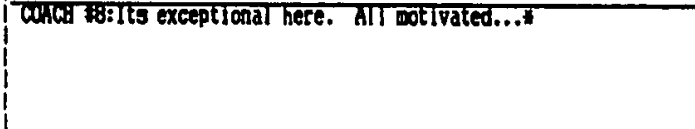 } & 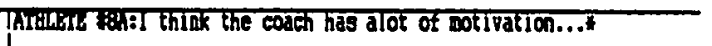 \\
\hline & 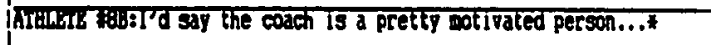 \\
\hline & 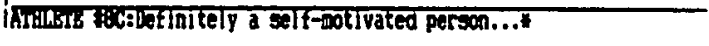 \\
\hline \multirow{3}{*}{$\begin{array}{l}\text { cunch } \\
\text { lother } 20 \text { are not very motivated in several areas.... }\end{array}$} & 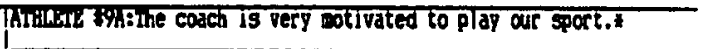 \\
\hline & 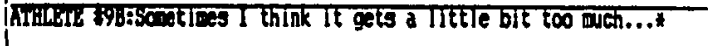 \\
\hline & 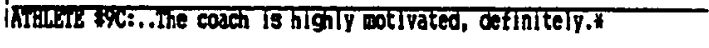 \\
\hline \multirow[t]{3}{*}{ Corked lo:onte a bit...t } & Thrildits Fios: he coach is vecy wotivated.: \\
\hline & 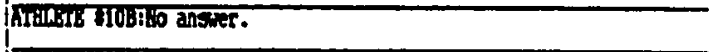 \\
\hline & 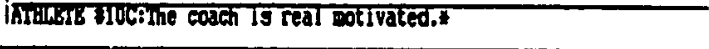 \\
\hline
\end{tabular}

sa Response that agrees with Athletic Director

Responses that agrees 39 of 40 


\section{RESPONGE ANALYSTS FORM}

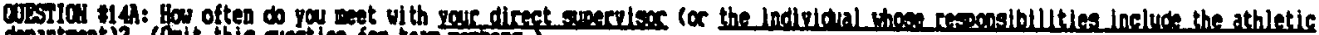

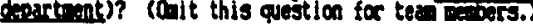

A.D.'S R.spousts: I've had the saee supervisar for eleven years. Starting thls year I an meetling ulth the Physical Director once s month. ine still get side tracked on departeantal isoves rathes than athletic isules...only meet vith the vice-Chancelloc through ay tnitiation...

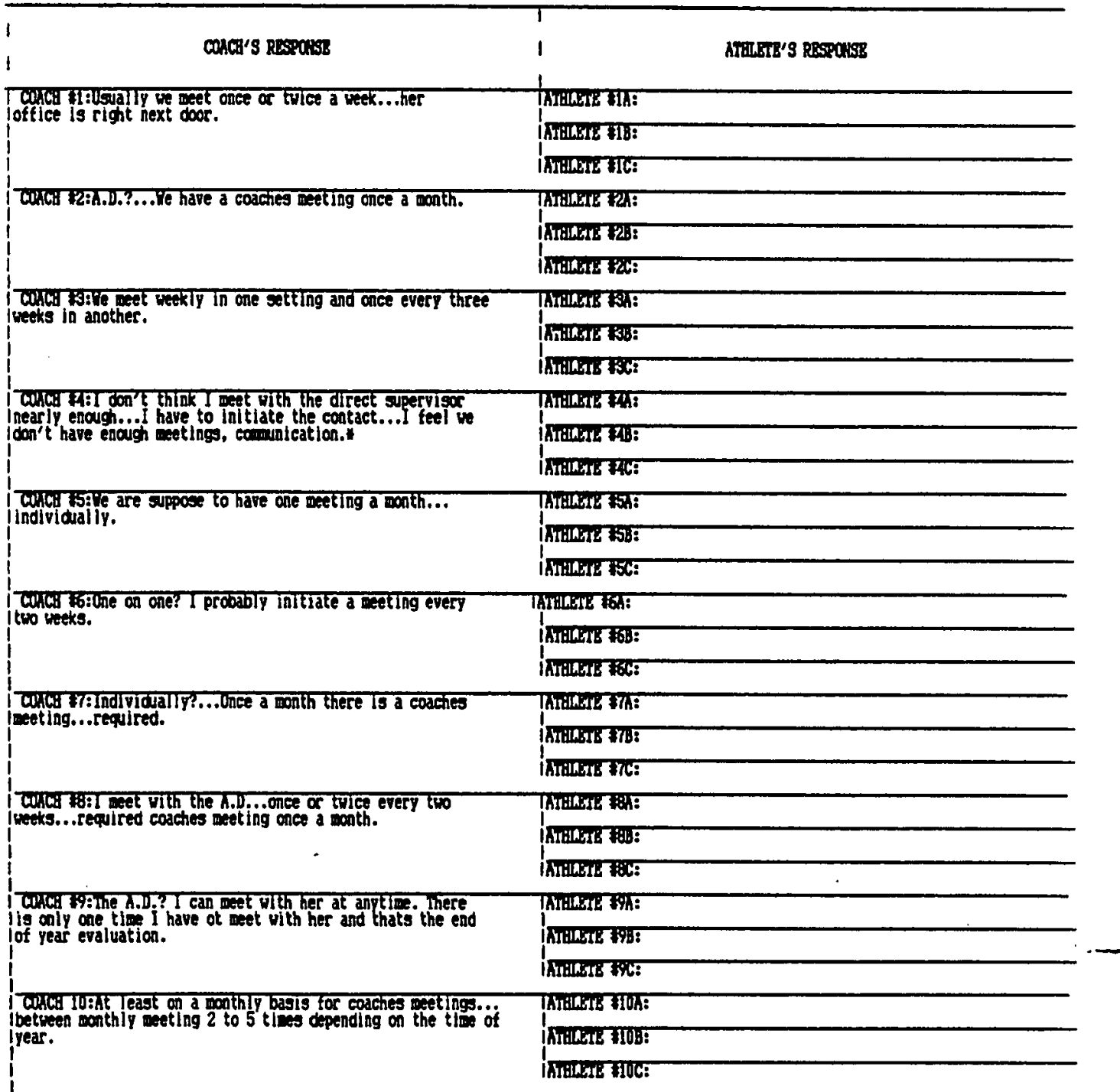

$k=$ Response that agrees with Athletic Director $\quad \&$ of Agreenent=.100 Responses that agree= 1 of 10 


\section{BESPONSE ANALYSIS FORM}

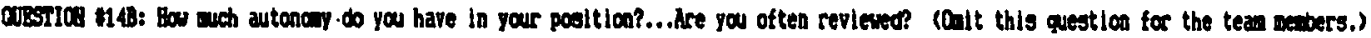
A.0.'S Reseunse;

\begin{tabular}{|c|c|}
\hline 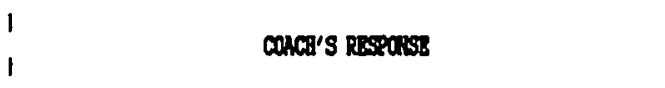 & 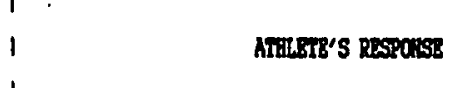 \\
\hline 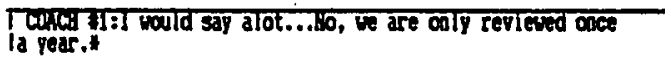 & 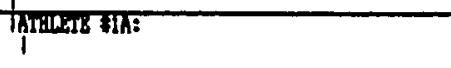 \\
\hline & IAMiLETE *IB: \\
\hline & ingulente th: \\
\hline 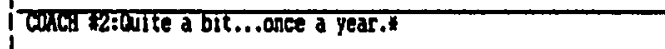 & ThIBLEIS R2: \\
\hline & Thaldere ted: \\
\hline & innilats tida: \\
\hline 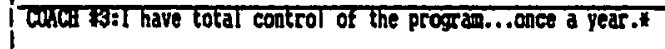 & Thrilatere ash: \\
\hline & 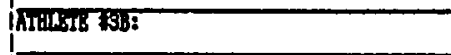 \\
\hline & intelbite tisc: \\
\hline 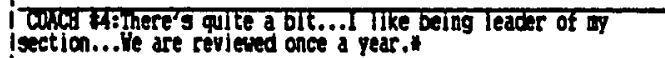 & Pradeate Th: \\
\hline & Antwors R: \\
\hline & Thrilasic WAL: \\
\hline 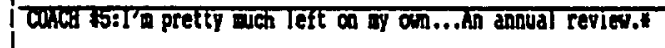 & 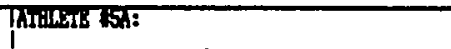 \\
\hline & Thithers tisj: \\
\hline & IAfibine 6s: \\
\hline 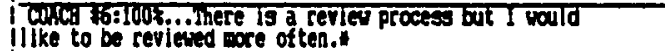 & Thribletes: \\
\hline & phildeste wab: \\
\hline$\cdot$ & intilhitio tac: \\
\hline 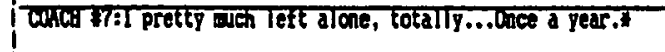 & ThuthBtE ins: \\
\hline & Arthedic Th: \\
\hline & Ithilleste Bre: \\
\hline 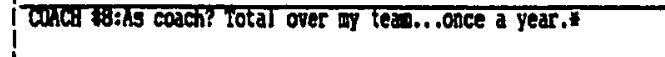 & hribers tik: \\
\hline & hrikens \\
\hline & Inilbite be: \\
\hline cahci signctually, I have a great deal... every year.: & Thrile:L Fin: \\
\hline & hillhede Fis: \\
\hline & indoldet tro: \\
\hline 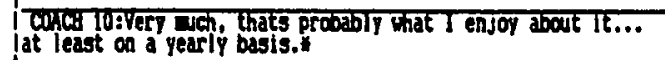 & Thible ofos: \\
\hline & AniLEIE IIU: \\
\hline & intilbiste tibe: \\
\hline
\end{tabular}

* Response that agrees uith Athletic Director $\quad$ of Agrement= 1.000 Responses that agree $=10$ of 10 


\section{RESPONSE ANALYSIS FORY}

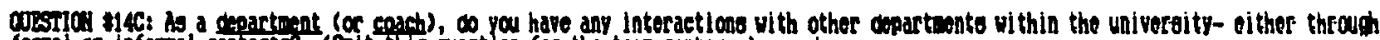
formal oc infochal contacts? (Ooit this question for the tean meders.)

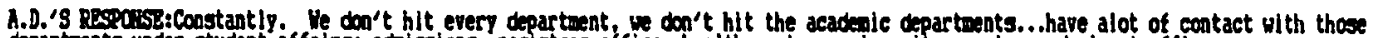
departwents under student affairs: adeissions, registras office, health center, university erents, and alumi office.

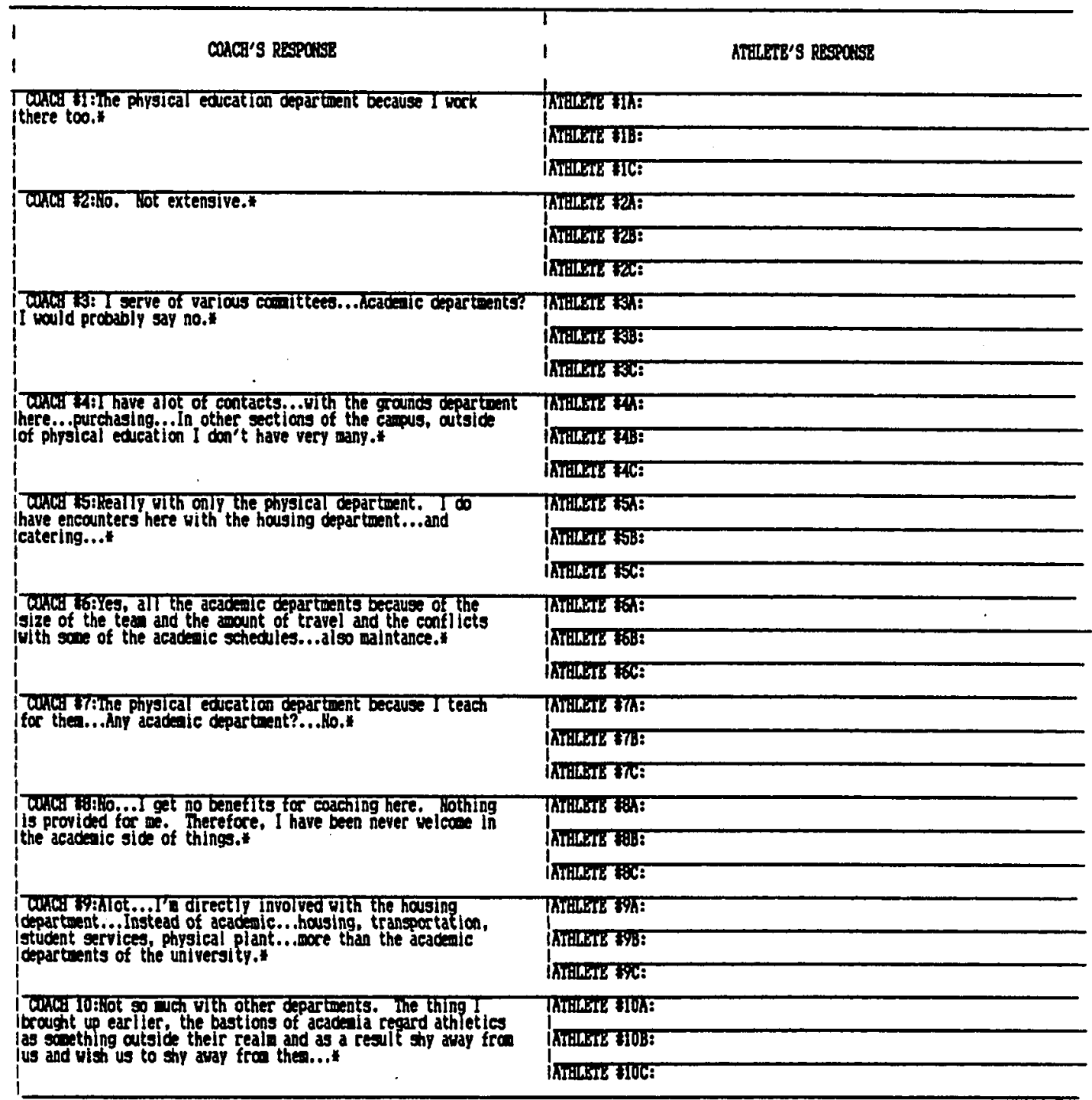

* Response that agrees with Athletic Director 


\section{RESPONSE ANALYSIS FORM}

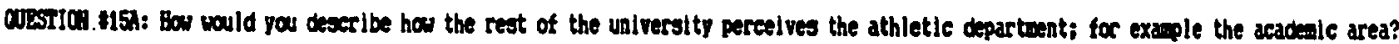

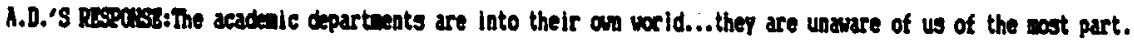

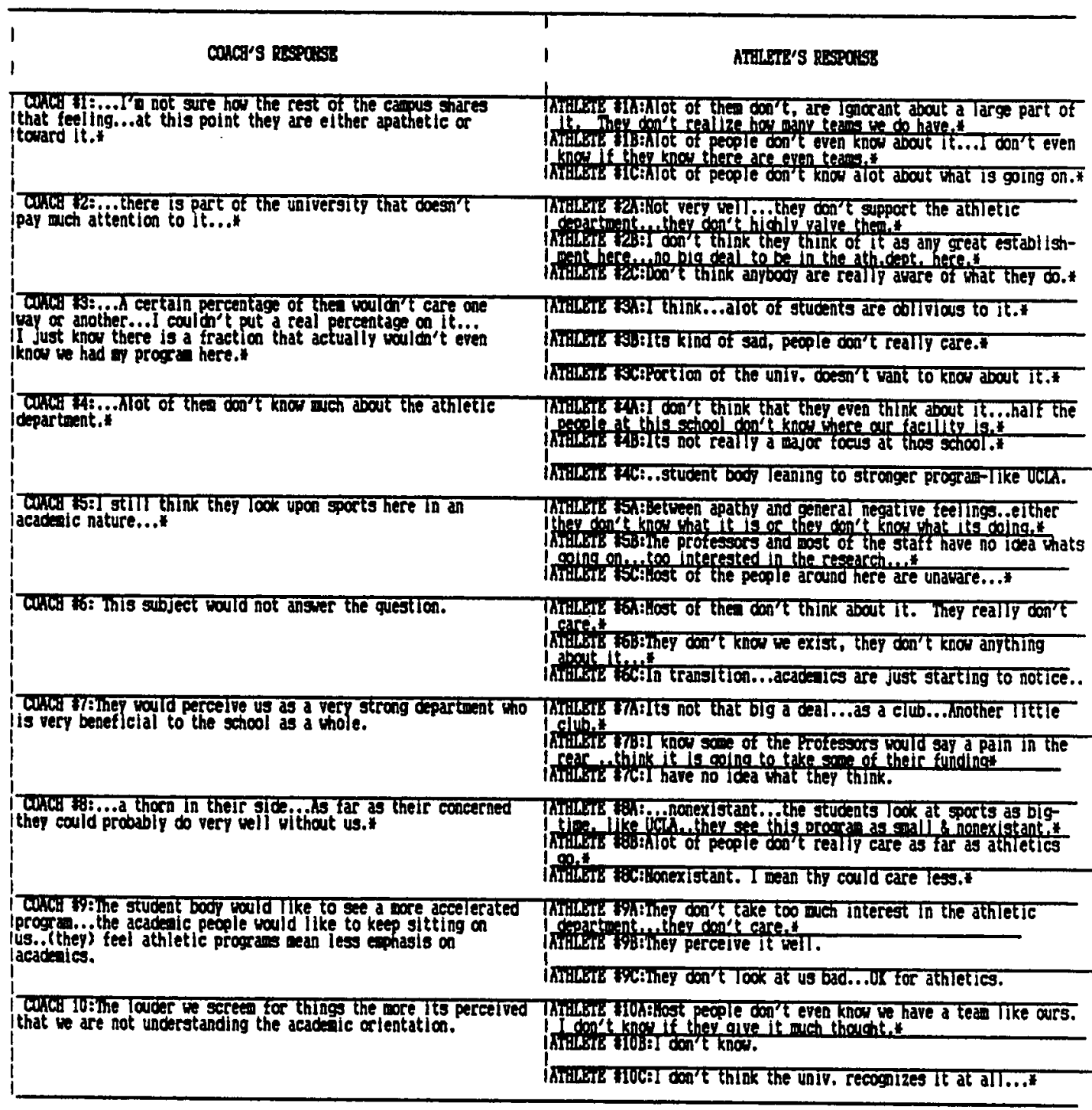

we Response that agrees uith Athletic Director

tof Agreesent $=.750$

Responses that agree $=30$ of 40 


\section{APPENDIX G}




\section{LIST OF QUESTIONS NOT USED IN THE \\ ANALYSIS OF THE DATA}

Quest Ion:

* Agreement

2. What has been the departments (or your teams) performance in NCAA reglonal or national competition?

See Appendix

D

8. In competing agalnst other DIII teams, $45.0 \%$ do you feel that UCSD's athletic teams' uniforms, equlpment, and travel schedules are above average, average, or below average in comparison to these teams?

9A. How do you feel other institutions (or coaches or teamg) view UCSD's athletic department (or specific team).

9B. Based on your experience has the UCSD program influenced any other institution's program in any way?

10A. Considering the athletic department is a part $10.0 \%$ of the total university environment, how would you say the department reflects the ideas of the culture of this university?

10B. What would you think others outside of the $60.0 \%$ athlet lc department would say concerning how $52.5 \%$ the department reflects the ideas of the culture of UCSD?

11B. What objectives do you see as important to $15.0 \%$ fulfilling these purposes?

13A. What do you percelve the task of the athletic $55.0 \%$ department to be?

13B. Do you feel that all members of the department $57.5 \%$ are committed to this task?

13C. Do you feel that the Individuals above you or Individuals below you) in the hierarchy are committed to this task?

13D. Have any new of innovat lve methods been introduced with in the athletic department (or specific team) since you have been involved in the athletic program?

14D. Do the caaches (or you) have other academic $40.0 \%$ responsibllities besides coaching? 
14E. If so, who decides these academic responsibilities?

15B. Would you say the athlet lc department represents $67.5 \%$ a typical of atypical university department as you perceive it?

15C. In what way? $25.0 \%$

15D. NOTE: only ask if the person considers the department to be atyplcal: Would you say that $51.9 \%$ the department is considered a problem by other departments in the university because of this atypical nature? 


\section{APPENDIX $\mathrm{H}$}




\section{Southwestern}

College

Apri1 24, 1987

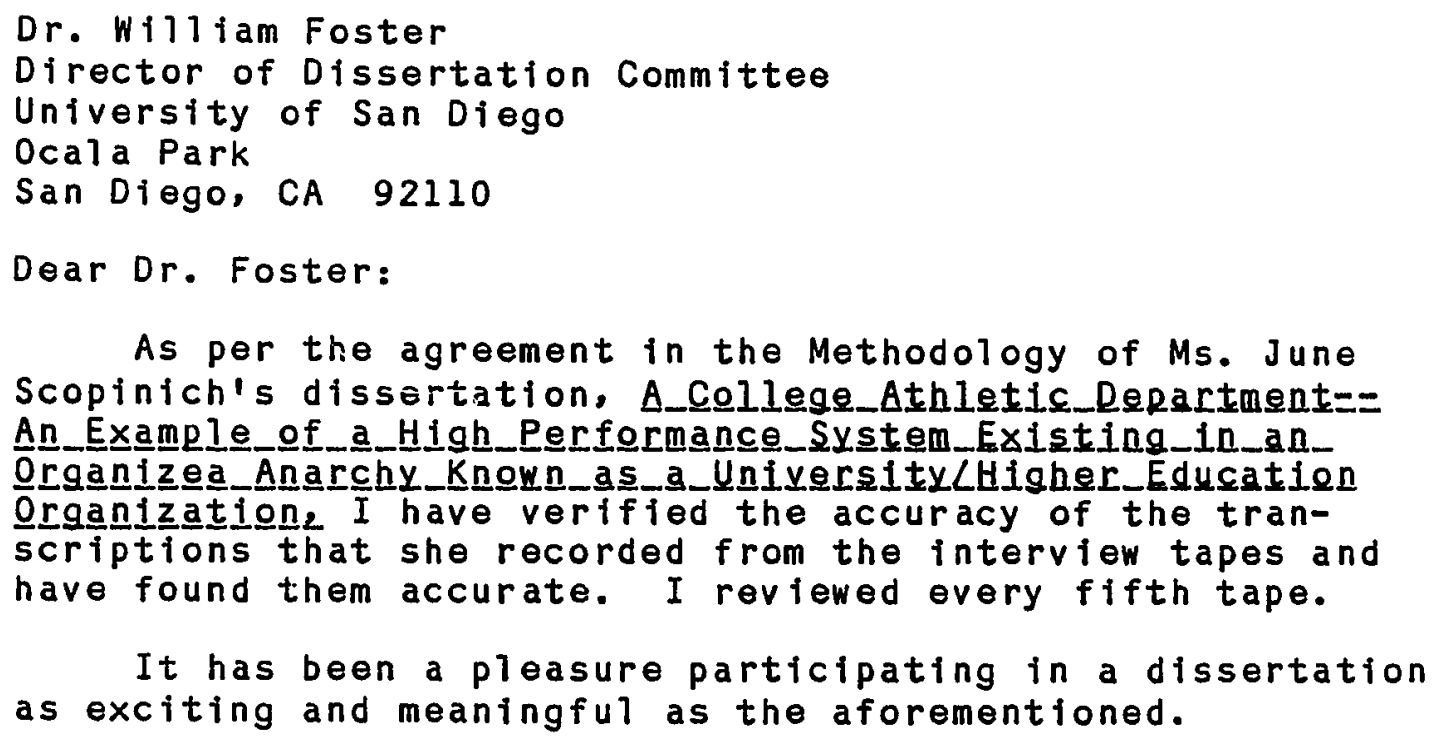

